1 BROWN

\& JUDAIC

STUDIES

\title{
Some Jewish Women in Antiquity
}

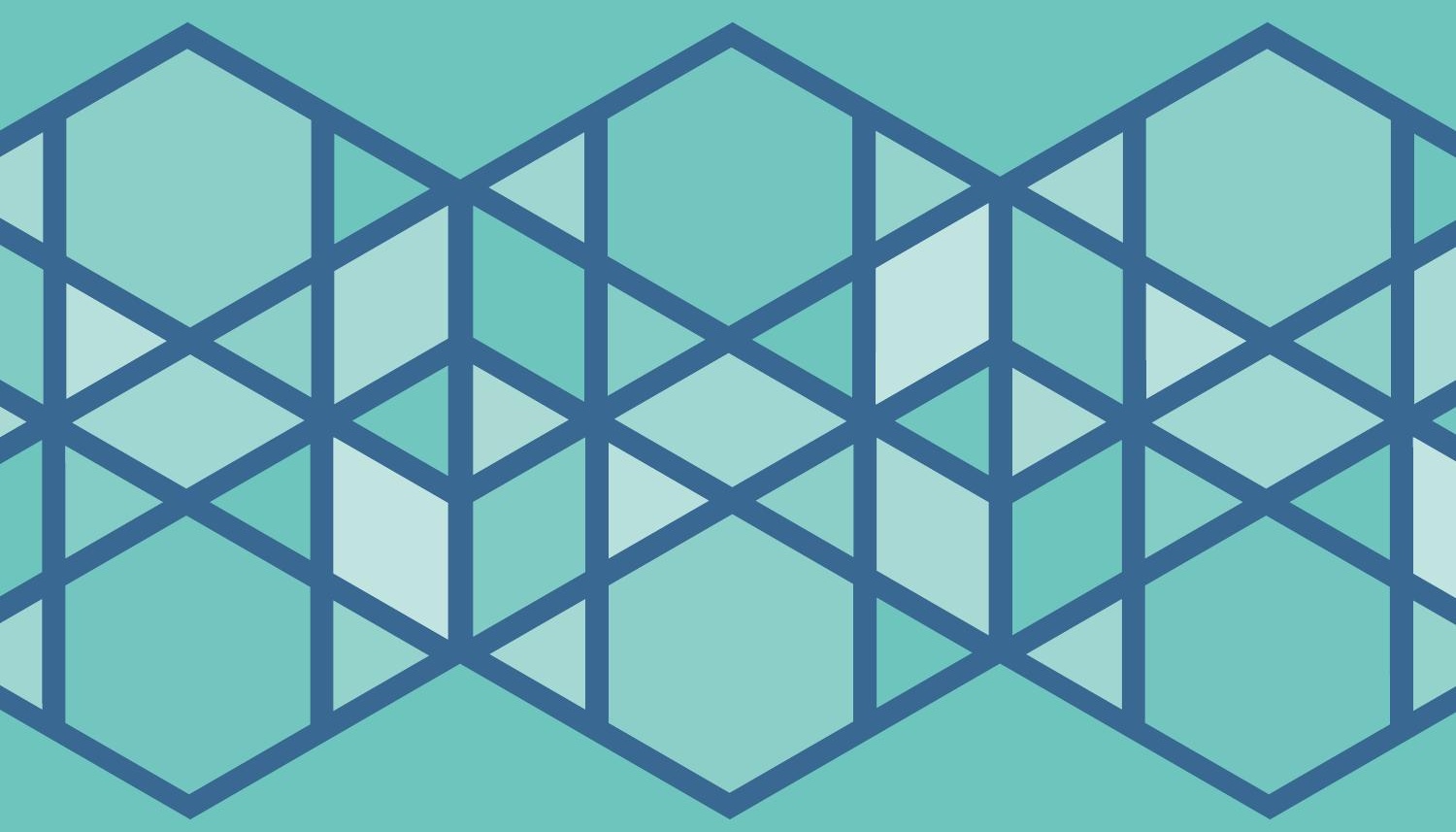

MEIR BAR-ILAN 
SOME JEWISH WOMEN IN ANTIQUITY 
Program in Judaic Studies

Brown University

BROWN JUDAIC STUDIES

Edited by

Shaye J. D. Cohen

Number 317

SOME JEWISH WOMEN IN ANTIQUITY

by

Meir Bar-Ilan 
SOME JEWISH WOMEN IN ANTIQUITY

by
Meir Bar-Ilan

Scholars Press

Atlanta, Georgia 


\title{
SOME JEWISH WOMEN IN ANTIQUITY
}

\author{
By \\ Meir Bar-Ilan
}

Copyright $\odot 2020$ by Brown University

Library of Congress Control Number: 2019953511

Open access edition funded by the National Endowment for the Humanities/ Andrew W. Mellon Foundation Humanities Open Book Program.

The text of this book is licensed under a Creative Commons Attribution-NonCommercial-NoDerivatives 4.0 International License: https: / / creativecommons.org/ licenses/by-nc-nd/4.0/. To use this book, or parts of this book, in any way not covered by the license, please contact Brown Judaic Studies, Brown University, Box 1826, Providence, RI 02912. 
FOR THE WOMEN IN MY LIFE:

MY MOTHER, MY WIFE AND MY DAUGHTER

FOR THEIR LOVE, CARE AND HELP. 



\section{Contents}

Preface

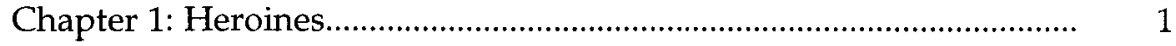

Chapter 2: Literate Women..................................................................... 31

Chapter 3: The Keening Women........................................................... 52

Chapter 4: Prayers by Women.....................................................................

Chapter 5: Sorceresses.......................................................................... 114

Chapter 6: Prostitutes........................................................................... 132

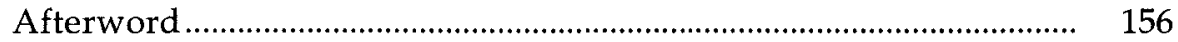

Bibliography........................................................................................ 159

Index of Women in Antiquity............................................................. 161

Index of Modern Scholars.................................................................... 163 



\section{Publishers' Preface}

Brown Judaic Studies has been publishing scholarly books in all areas of Judaic studies for forty years. Our books, many of which contain groundbreaking scholarship, were typically printed in small runs and are not easily accessible outside of major research libraries. We are delighted that with the support of a grant from the National Endowment for the Humanities/ Andrew W. Mellon Foundation Humanities Open Book Program, we are now able to make available, in digital, open-access, format, fifty titles from our backlist.

Meir Bar-Ilan's book, Some Jewish Women in Antiquity (1998), was one of a wave of books written at that time that dealt with gender and ancient Judaism. Bar-Ilan provides a typology for different representations of women in Jewish texts and explores how these representations might relate to the historical reality.

This edition contains typographical corrections of the original text.

Michael L. Satlow

Managing Editor

October, 2019 



\section{Preface}

This book sets out to characterize different types of Jewish women in Eretz-Israel over an extended period of more than a thousand years, from the biblical period to the time of the Mishnah and Talmud.

It goes without saying that it is almost impossible to compare historical figures over such a long period of time, especially given the textual reality in which they are reflected. The different methods of research employed in this study and the present state of scholarship in the various fields proscribe any arrival at a clear-cut historical picture, and perhaps such a picture should not even be sought. Any attempt to flesh out the historical figures of individual women and bring them to life has purposely been avoided here; the study concentrates instead on that unique, discrete character trait which is the dominant one in the literary sources. The reason for this is that information about women in antiquity is surprisingly meager, so much so that there is no use trying to reconstruct their historical existence; these fragmentary pieces of information are the literary expression of social sentiment.

Neither have precise dates been used for the characters of women analyzed here, as this book does not belong to the genre of historical biography; rather, it sets out to describe the social history of different women in Eretz-Israel over a continuous period of centuries. The substantial part of the book discusses women in the post-biblical period and its literature: the Apocrypha and talmudic texts, but the study does not concentrate on a specific era, nor is it limited to a description of Jewish women. The scope of this volume, then, extends beyond the title's specified time and place to include women of other times and places as well.

It must be recalled that the inhabitants of Eretz-Israel in what is today termed the talmudic period lived in a post-biblical era, not only chronologically but culturally as well; people were familiar with the Bible to a greater or lesser degree. The Bible was more than a set of commandments; it constituted the cornerstone of daily life, and biblical characters were the heroes of the time. That is to say, women in the post-biblical period were familiar with their feminine predecessors, through acquaintance with the written text or oral accounts. It is thus inappropriate to limit the discussion to women in the talmudic period, since this was a cultural extension of the biblical period, despite the opinion 
held by some scholars as to a cultural disjunction between the two periods.

In this regard, the book ignores the modern Israeli division of the study of ancient Jewish culture into two separate disciplines: Bible studies as one academic field, Talmud studies as another. This division is unwarranted on nearly all counts, and one objective of this book is to bring about a rapprochement between the two fields. Political analysis can draw only a vague historical boundary between the two periods, one that disappears altogether when subjected to the scrutiny of sociological analysis. It is pointless to insist upon clearly delineated historical periods, and most detrimental to our subject of study.

The chronological and cultural gap between the Jewish sources Written Law and Oral Law - is glaringly revealed when the study of apocryphal literature is omitted from the two academic disciplines mentioned above, and both are left wanting. The apocryphal corpus was largely composed in Eretz-Israel over a time overlapping in part the composition of the biblical books and in part the talmudic sources. The failure to study apocryphal literature, which today is so easily accessible, albeit not in its entirety, is an oversight that heightens the wrong already inflicted upon the study of Jewish society in Eretz-Israel in the biblical and post-biblical periods.

This is a study in the comparative history of the status of women in Eretz-Israel in antiquity, and, like any comparative study, it addresses the same issues in different circumstances, contributing to the relatively new field of Jewish social history; it also furnishes additional proof, should any be necessary, of the scientific momentum to be gained by inter-disciplinary study like the present combination of history and the social sciences. The historical study of women in antiquity remains yet to be investigated for several reasons. Aside from the fact that most historians are men, and as such do not often engage in the study of the status of women - the contrary is also true: most of the social science scholars who do address the issue of women are themselves women. The subject of women in antiquity is plagued by different, even contradictory approaches. First, the prevailing modern religious approach seeks to stress the positive and enlightened elements in early Judaism. In this view, women in early Judaism are noble and enjoy a high legal status and respect. This unhistorical approach distorts the picture of the status of women in antiquity, and clearly contributes nothing to an understanding of the subject. The opposite approach is evident in those studies of women's legal status in antiquity which disclose their conclusion by raising the very question in their title. Anyone who subjects 
the legal status of Jewish women in antiquity, and the status of women in all traditional societies, to objective scrutiny, has no choice but to admit to women's inferior socio-legal status. Hence, studies on women's legal status are generally biased from the start, and there is no possibility for a scholar in this field to add to an understanding of women's social position, but only to demonstrate a basic awareness of the discrimination against women.

Besides these contradictory approaches, one exalting women, the other relegating them to an inferior rung on the socio-religious ladder, there is a third that upholds a total denial and suppression of the subject. Voices are heard to the effect that there is no such field as "Women's Studies" in any historical period, as there is no field of "Men's Studies." However, those historians who are learned in conventional historiography forget the basic fact that male historians have traditionally confined themselves to men only as subjects of inquiry. Political and economic history of the ancient world is history of and about men, and women are only mentioned incidentally. It need not be said that the number of women who left their mark on political developments in antiquity is negligible.

These three approaches - which can be said to have joined together in order to dismiss the history of women - seem to me substantively unjustified and historiographically sterile. That is to say, these approaches do nothing to redeem women in history (and their modern counterparts) from historical oblivion. Conversely, a real contribution towards an understanding of the status of women in antiquity can come only from comparative history, that is, one devoid of the religiotheological aspect or the legal aspect (which serves anti-religious interests). However, defining the subject remains the essential difficulty, following the rejection of the facile solutions mentioned above. The solution proposed here to the problems besetting scholarly discussions of the status of women in antiquity entails an inquiry into the status of different women in ancient society, in a social, not necessarily familial context. Instead of concentrating on all the information about a given character, with all the ensuing difficulties, a different approach is proposed here: to discuss a single human trait as it is refracted by many different women.

The book is divided into the following topics: heroines, women's literacy, keening women, prayers said by women, sorceresses, and prostitutes. Each chapter presents first the literary sources in chronological order, followed by a discussion of the social aspect of the historical facts. What emerges from this presentation is a picture of women's social 
status, men's attitudes toward women, feminine literary creativity, etc. This examination - sociological rather than historical - eliminates the need for a discussion of the question whether each woman was indeed a historical figure or merely a literary paradigm. The purpose of the book, then, is to discuss women's social status as reflected in the sources, rejecting the argument heard against using examples of women who may have existed only in the imagination of their creators. Their historical existence remains an open question, as for example in the story of Judith, and all the texts are discussed on the assumption that the wishes and desires of their authors gave form to history just as history formed the authors.

Let it be said immediately that some of the female characters discussed here were an aberration even in their own time. Statistically speaking, the present volume treats a fraction of a percentage of all the woman who lived in antiquity, since obviously the number of heroines was tiny, as was the number of literary women, professional keeners, sorceresses and prostitutes. It will be made clear that even the praying women are not representative, since most of females' prayers were uttered in times of dire straits and distress. However, it is precisely these situations of crisis that can provide information about women and their social standing beyond the dry facts of whether women were permitted or forbidden to engage in a given activity. That is to say, just as personal crises in modern times force one to rise to the occasion, it may be said that the status of women in antiquity can also be determined from their extreme or unusual behavior.

It is to be hoped that the book will promote women's studies in general and in antiquity in particular, and will underscore the importance of the social history of ancient times. This book does not encompass all the issues of feminine literature and makes no claim to comprehensiveness. Indeed, the hundreds of books and articles that I consulted for this book demonstrated clearly that the study of Jewish women in history is still in its earliest stages. The masculine historiographical and philological tradition, especially as it has many achievements on its side, will only reluctantly make room for a field of scholarly inquiry that was unknown a very short while ago. Only a combination of varied scholarly methods and approaches can make Women's Studies productive and bring the social sciences into the focus of historiographical inquiry.

In conclusion, may I add that I am aware that my analysis of the status of women in antiquity is not shared by all. In a world where both male 
chauvinism and reactionary religion prevail, there is bound to be unwillingness to read of sorceresses or prostitutes in antiquity, unless for the sensationalism therein. At the same time, it turns out that my book enjoys greater support among its female readers, and in any case it may make a contribution, albeit a modest one, towards an understanding of women's status in antiquity. If we accept the dictum that history is written by the victors, let the purpose of this book be to present the history of the underdog.

I wish to thank all the critics of this book, first and foremost my students at Bar-Ilan University who attended classes where I presented my ideas in progress. Their reactions helped me formulate my thoughts and revise the first draft. I also wish to thank my teachers and friends who labored along with me in reading all or part of the book: Prof. Shmuel Vargon read the first chapter, Professor Aaron Demsky read the second chapter, Professor Nissan Rubin read the third chapter, Professor Rabbi Joseph Tabori read the fourth chapter, and Dr. Rabbi Simcha Fishbane read the fifth chapter. Professor Danny Boyarin, Dr. Yael Levin-Katz and Professor Rabbi Daniel Sperber read the entire manuscript. It goes without saying that any errors are mine alone. The remarks made by these readers greatly assisted me in arriving at the final version, and there is no doubt that the book is better for it. The librarians at the inter-library checkout at Bar-Ilan University put much effort into helping me find the books I needed, and the university librarians provided helpful assistance.

It should be noted that an early version of the fifth chapter has already been published as a paper in: Herbert W. Basser and Simcha Fishbane (eds.), Approaches to Ancient Judaism (New Series, Atlanta: Scholars Press, 1993), V, pp. 7-32, and I wish to thank Scholars Press for their permission to publish my work here.

This work was supported by the Committee for the Advancement of Research at Bar-Ilan University, and it is my pleasure to thank Bar-Ilan University once again. Ms. Sara Friedman translated my book into English and I owe her much. Many thanks to all.

Meir Bar-Ilan Jewish History Department Talmud Department Bar-Ilan University Ramat-Gan, Israel 



\section{CHAPTER 1}

\section{Heroines}

There are many possible answers to the Mishnah's question "What makes a hero?"; we will confine ourselves here to a single answer. A heroic person is one who saves his or her own life or the lives of others in a life-threatening situation, thereby displaying resourcefulness and courage.

The present chapter will analyze descriptions of women who accomplish brave deeds in biblical literature, the apocryphal works of the Second Temple period, and finally, in talmudic literature. We will subject each individual case to a historical-literary analysis, consisting of a short synopsis of the relevant courageous act, followed by a description of the characterization of the female protagonist. Occasionally heroines of different periods will be compared, charting the transformations that took place over time in female characterization. ${ }^{1}$ We will isolate and analyze each component of the portrayal of the character and see how they relate as a whole. Next, we will address the sociological aspect, and examine the social significance of the unusual descriptions presented below. The hypothesis underlying the literary analysis submitted here holds that each story encodes a certain message to the reader, at times explicit, at others only implicit. Decoding the message, or programmatic content, of the stories in a given period will reveal something of the values and perceptions of the authors and their readership in the ancient world, as well as of the status of women in ancient society.

\section{Biblical heroines}

The Bible, as well as subsequent literature, recounts deeds of valor both by men and women, but the number of heroines is infinitely smaller

1 The extensive literature written about women in the Bible deals with various aspects of the subject. See, for instance, Phyllis Bird, "Images of Women in the Old Testament", Rosmary Radford Ruether (ed.), Religion and Sexism (Simon and Schuster, New York, 1974), pp. 41-88; T. Friedman, "The Shifting Role of Women, From the Bible to Talmud", Judaism, 36 (1986), pp. 479-487. The only study I know of that analyzes separate traits of women and compares them with other characters from later historical periods, as I do here, is Athalya Brenner, The Israelite Woman (JSOT Press, Sheffield, 1985). 
than that of the men who acted as saviors of their people. Compared to Moses, Joshua, and the Israelite judges and kings, only a smattering of heroic women are mentioned, whether explicitly or even implicitly. Thus, for instance, the story of the midwives, Shiphrah and Puah, is an account of brave women who not only dared to transgress against the king's decree, but also had the effrontery to lie to him, endangering their own lives to save the lives of infants (Ex. 1:15-21). Later, Jochebed, assisted by her daughter Miriam, hides her son - the future leader of Israel - and together they care for the child. Surely they, as well as Pharaoh's daughter and her maidservant, were aware that they were defying the king, but they nevertheless, joined in a conspiracy of women against the all-male forces of the king and his officers, to save the infant (Ex. 2:1-10). ${ }^{2}$ Clearly we have here an instance of women's solidarity, women as symbols of caring and courage, acting for the protection of a male child, set against the king, the epitome of cruelty. Zipporah, the wife of Moses, displayed bravery of another kind. Her initiative and daring saved her baby's life from God's wrath (Ex. 4:24-26). Thus, the leader's mother, his sister, his nurse and her maidservant were all heroines, though the term itself is not used of them in the Bible. It is therefore not surprising that the leader's wife is later also seen to be a heroine.

The idea of women rescuing men by hiding them, i.e., by passive bravery, recurs frequently throughout the Bible. The prostitute Rahab saved the lives of the Israelite spies by hiding them. She then purposely misled the king of Jericho (Joshua 2:1-25), in language that attests to her wisdom. ${ }^{3}$ She too, like Pharaoh's daughter, risked her own life for the sake of an Israelite, and the Israelites rewarded her by sparing her life in this world, and, the midrashic tradition adds, by converting her to Judaism, which would ensure her everlasting life in the hereafter. ${ }^{4}$ Similarly, Michal, the daughter of King Saul, rescued her husband David; here a princess once more deceitfully defies her father (1 Sam. $19: 11-14) .{ }^{5}$ This was also the nature of the act of a woman from

2 It comes then as no surprise that Pharaoh's daughter was converted (see Megilla 13a) and given the Hebrew name of Batya (following I Chron. 4:18), apparently with the intention of rewarding her in the hereafter for her bravery. See Yael Levine, Midrash Eshet Hayil, M.A. thesis, Bar-Ilan University, Ramat-Gan, 1986, p. 61 (Hebrew).

3 For the portrayal of Rahab as a wise woman, see Y. Elizur, "Hochmat nashim banta beita' - mekoma shel ha-isha ba-hevra ha-mikrait', Mishpehot beit Israel, Sefer hakinus le-mahshevet ha-yahadut: year 18 (Jerusalem, 1976), pp. 153-166 (Hebrew).

4 See Chapter Six, below, on Rahab the prostitute.

5 Note the similarity between this fraudulent act and the fraud and theft perpetrated by Rachel on her father (Gen. 31:19-35). 
Bahurim, who saved the lives of Ahimaaz and Jonathan by first hiding them and then lying to their enemies (2 Sam. 17:17-20). ${ }^{6}$

Another, anonymous heroine is the "wise woman" of the town of Abel of Beth-maacha (2 Sam. 20:16-22). While Joab was laying siege to the city, this woman was able, through her cleverness, to persuade both him and the besieged townspeople that it would be wise to kill Sheba, the son of Bichri, who rebelled against the king, thereby saving the entire town of Abel Beth-maacha. The Bible again mentions that this was a "clever plan." Acting upon it, they beheaded Sheba and threw the head down to Joab, and the city was saved. This woman's power lay in her wise words. Where the other heroines employed falsehoods in order to rescue men, she resorted to cunning, saving her town and all its inhabitants. ${ }^{7}$

Another tale of courage recounts the deeds of Jehosheba, daughter of King Joram and wife of the priest Jehoiada. By hiding Ahazia's son Joash for six years (2 Kings 11:1 ff; 2 Chron. 22:2 ff.), she rescues his life. This took place when Athaliah, mother of Ahazia, king of Judah, seized the throne after her son's death, and killed all the males of the royal line. ${ }^{8}$ Here we have a war of sorts waged by one woman against another;

6 The authors of the Midrash have it that this heroine was the wife of Shimi (Midrash Shmuel 32:9; Midrash to Esther, A. Yellink, Beit Hamidrash, 1, Jerusalem, 1938, p. 23, Hebrew). In contrast to these biblical accounts of physical rescue, later sources dwell on moral salvation from transgression, in the words of Rav Shmuel bar Rav Yitzhak in 6. Sanhedrin 109b: "Sit still, and I will rescue you. She gave him wine to drink, and he swooned, drunk, and she lay him down in the house." This non-biblical female character (Num. 16:1 ff.) may serve as an exemplary figure in general, and as example of what is missing in the Bible, in particular. Not only does the woman come to the rescue (contrary to the stereotype of women from Eve to Jezebel causing death), but like Michal, she, too, is an instrument of rescue. The means of rescue is wine, contrary to the erstwhile role of wine as the means of achieving fobidden seduction (see below, note 11). See below, Chapter Four, on that woman's prayer.

7 For more about this wisdom, see below, chapter 2, and see also: Claudia V. Camp, "The Wise Women of 2 Samuel: A Role Model for Women in Early Israel?", $C B Q, 43$ (1981), pp. 14-29. In the pseudo-Jonathan translation of Gen. 46:17, this wise woman is Serah, daughter of Asher (see also Gen. Rabbah 94:9, ed. Theodor-Albeck, p. 1182; Aggadat Bereshit,2 ed. S. Buber, Vilnius, 1925, pp. 38-39, Hebrew). Sara rescued an Israelite city, and in reward for this act of bravery (and not for others attributed to her) was permitted to enter the Garden of Eden while still alive (Derekh Eretz Zuta 1:18, ed. D. Sperber, Jerusalem, 1982, p. 3, Hebrew).

8 On Athalia as mother inciting her son to transgress - "for his mother was his evil adviser" - and the character of the mother in the Bible in general, see G.H. Cohen, "Ha-isha u-mekomah be-gibush ha-hevra ve-hahistoria batekufat ha-mikra," Hevra ve-historia, Annual Conference of Jewish Thought (Jerusalem, 1980), pp. 397-407 (Hebrew). For a comparison of Queen Athalia as ruler and destroyer with the queen of Egypt and the queen of China, see A. Steinzalz, Women in the Bible,3 (Tel-Aviv, 1988), pp. 79-85 (Hebrew). 
the aunt, Jehosheba, fights Athaliah, the grandmother and the queen. Jehosheba's behavior bears a marked affinity to the story of Jochebed: women hiding an infant in defiance of the king seeking to kill all the males; the hidden infant, once grown, "did what was right in the eyes of the Lord" and sealed a covenant between God and the people of Israel. ${ }^{9}$ These heroines assumed only a secondary role in the patriarchal biblical narrative. Although several other heroines do appear in the Bible, let us turn for the present to the heroines in apocryphal sources.

\section{Heroines in the Pseudepigrapha}

Several heroines appear in the Books of the Apocrypha, which are for the most part post-biblical compositions, and it is interesting to see how they differ from their biblical foremothers.

\section{Judith}

The story of Judith, composed circa the fourth century B.C.E., recounts how Judith rescued her town and its people. ${ }^{10}$ Her deed is recounted in an eponymous composition which tells in detail of a female protagonist at the waning of the biblical literary period. Judith and her deeds are described extensively, as are her wealth of rhetoric, her wisdom and her beauty. Making the most of her talent and looks, she seduced Holofernes, the Assyrian general who was laying siege to her birthplace in Samaria. At first she duped him into thinking that she was fleeing from her fellow Jews, and that the village would surrender to him (like Rahab and her speech to the spies). Later on, when the general sought carnal relations with her, she pretended to agree but plied him with wine until he fell asleep, drunk. Judith prayed to God for help, and then she cut off Holofernes's head. ${ }^{11}$ This led to the rout of the Assyrian

9 Note the important role of the wet-nurse in both stories. Women are responsible for the main part of the plot, but the narrator allots them only secondary importance.

10 See Y.M. Grintz, Sefer Yehudit (Mossad Bialik, Jerusalem, 1957, Hebrew). On the survival and redaction of the work throughout the Middle Ages see A.M. Habermann, Hadashim gam yeshanim, (Jerusalem, 1976, p. 40 ff. (Hebrew); M.B. Lerner, "Yalkutei Maasiyot", Kiryat Sefer, 41 (1986-7), pp. 867-891 (Hebrew). For a general survey of pseudepigraphical literature see James $\mathrm{H}$. Charlesworth (ed.), The Old Testament Pseud-epigrapha (Doubleday, New York, 1983-1985); Sidnie Ann White, "In the Steps of Jael and Deborah: Judith as Heroine", James C. VanderKam (ed.), "No One Spoke Ill of Her": Essays on Judith, (Scholars Press, Atlanta, 1992), pp. 5-16; Alice Ogden Bellis, Helpmates, Harlots, and Heroes: Women's Stories in the Bible (Westminster/John Knox Press, Louisville, Kentucky, 1994), pp. 219-223.

11 Wine was the agent of death for Holofernes and also for Sisera, Jael's victim, 
army. Not only were her townspeople saved, but indeed, the entire Israelite people. The high priest and elders of Jerusalem came to pay their respects to Judith and extend praise. All the women of the land came to congratulate her, and then all proceeded to dance, "and all the men of Israel followed." Judith then sang a new hymn of praise to God, and the people responded and sang with her. ${ }^{12}$ We should add that this story was known to the Jews in the Middle Ages, and was linked, albeit artificially, to the bravery of the Maccabees against the Greeks, celebrated in the feast of Hannukkah.13

This story has preserved its original form to a greater degree than all the other apocryphal books. It portrays a woman who integrates all the virtues: beauty, wisdom, rhetoric, etc. In order to understand what motivated the innovation in the characterization of Judith compared with preceding literature, the reader must examine biblical literature, notably those passages describing acts of bravery carried out by women. Each of these accounts will be considered in detail, and we will heed similarities between the characters as well as differences.

The biblical narrative most closely resembling the Book of Judith is, of course, the account of the brave act of Jael, wife of Heber the Kenite, when approached by Sisera, the Canaanite general (Judges 4:17-22; 5:2427). Sisera was fleeing the Israelite army headed by Barak and Deborah, and chanced upon the tent of Jael. Sisera trusted Jael not to disclose his place of hiding, but far from extending hospitality, as he might have expected of the children of Abraham (Gen. 18:2), she killed him. In other words, she acted bravely, though she herself was in no actual danger. However, we must note the differences between the two heroines, Jael and Judith. First, Jael was not an Israelite woman, and she

according to pseudo-Philo 31:6 (Pour wine with milk). In the Bible, wine was the active agent in the incident involving Noah's homosexuality or castration, according to the talmudic sources (Sanhedrin 70a). Wine was responsible for the incest between Lot and his daughters (Gen. 19:31-38). In antiquity wine was considered an aphrodisiac. See Hosea 4:11; Ben Sira 19:20; Testament of Judah 14:1-17,4; Testament of Issachar 6:3; 2 Baruch 4:8-12. See also: M. Bar-Ilan, "Behinat hanusah, Inyanim Erotieim umaasei Keshafim bemegillat Shir-hashirim," Shenaton lemikra uleheker hamizrah hakadum, 9 (1987), pp. 31-53 (Hebrew). Cf. below, the drunkedness of Amnon and Parshaz.

12 Judith is superior here to Miriam, sister of Moses (Ex. 15:21), as Miriam led only the women in song, while Judith led men too; Miriam repeated the song uttered by Moses, while Judith sang a new song (see Chapter Four, below). Moreover, the fact that the high priest went to see her reflects her superiority over Jephtah, whom the high priest refused to see (Gen. Rabbah 60:3, ed. Theodor-Albeck, p. 643). It is not surprising, then, that all the women of Israel came to see her, as there had never before been a figure of such high standing.

13 Grintz, ibid., p. 196 ff. 
chanced upon the scene of action inadvertently, unlike Judith, who took the initiative in killing her enemy. One might say that the opportunity came to Jael, whereas Judith sought it out. Second, Jael was under no threat of sexual violence from Sisera; Judith, on the other hand, was threatened sexually by the gentile general. ${ }^{14}$ Third, Jael killed Sisera with a tent pin, not a usual weapon, whereas Judith felled her enemy with his own weapon, acting in this respect in true manly fashion, much like David himself. Fourth, Sisera's death did not have serious repercussions on the outcome of events, and had Jael not killed Sisera, Barak himself would have done so. Judith's act of courage, on the other hand, altered the course of the war and influenced the fate of all of Israel. Judith, then, is a fitting role model for the daughters of Israel, unlike Jael.

A similar incident of a woman slaying her enemy appears in Judges 9:53-54. Abimelech was laying siege to the city of Thebez, and all the townspeople, men and women, sought refuge in a fortified tower. When Abimelech approached with the intention of burning down the tower with all its occupants, "a woman dropped an upper millstone on Abimelech's head and cracked his skull." And then we read the following: "He immediately cried out to his attendant, his arms-bearer, 'Draw your dagger and finish me off, that they may not say of me, "A woman killed him!' So his attendant stabbed him, and he died." It is thus clear that murder at the hands of a woman was considered much more demeaning than other forms of death, and indeed this is stressed as well in 2 Sam. 11:21. The result of the deed of the woman of Thebez was that she herself was saved, as well as all the townspeople. Compared with the description in the Book of Judith, I believe this event is merely episodic. The two accounts, that of Judith and that of the woman from Thebez, both of whom saved their towns, are still quite different. It is an act of bravery of much greater magnitude to kill one's enemy face to face (as did Ehud ben Gera, for instance, Judges 3:20-21), than to drop a stone on him from above. Hence, Judith was a braver and wiser woman

14 This is the simple meaning of the biblical text, but the talmudic sages had different opinions on this matter. Midrash Hagadol on Gen. 23: 1 (ed. M. Margaliot, Jerusalem, 1967 , p. 370, Hebrew) says that Sisera "drank wine until he became inebriated. He demanded that she sin. Immediately 'she smashed and pierced his temple."' However, according to R. Yochanan in Horayot 10b: "That profiligate had seven sexual connections at that hour; for it is said 'Between her feet he sank, he fell, he lay', etc.." Perhaps the view that links sexual relations to this incident derives not only from a desire for poetic balance, but also out of personal familiarity with similar incidents. See Abodah Zarah 71a, and also Y. Zakovitch, "Ha-isha basiporet ha-mikrait - mitve," Beit Mikra, 32 (1987), pp. 14-32 (Hebrew). 
than the woman of Thebez, and she deserved the gratitude of the people, as the other did not.

Judith and the woman of Abel Beth-maacha were both women who delivered their towns from danger, and both began the process by consulting with the city elders. However, Judith's deed led to the rescue of the entire country, and she was not a woman of words alone, but of action. In other words, her bravery was greater than that of the wise woman of Abel Beth-maacha. Her superiority is evident in the number of verses allotted each woman, respectively. While most of the Book of Judith (nine out of sixteen chapters) is devoted to Judith, only seven verses tell of her biblical counterpart, who remains anonymous throughout. The fundamental difference between the two women is thus made clear.

We must now examine the literary treatment of another woman who acted much like Judith: Queen Esther. Both women are eponymous heroines of a biblical or post-biblical Book; both delivered their people from danger, yet a vast gulf lies between them. While the Book of Judith is replete with overtones of religious fervor, in the words of Y.M. Grintz, the Book of Esther is entirely devoid of any religious facet, as is apparent, inter alia, from the omission of God's name in the Book. Esther was endowed with a single positive quality: namely, her beauty, while Judith was beautiful as well as rich, wise and brave. In addition Judith was righteous, observant of every commandment and fasted frequently. ${ }^{15}$ Esther, on the other hand, is prepared to wed a gentile king in return for a life of luxury at court. Esther is not possessed of any religious values, and the author tells us nothing of the events during the days that she and her maids fasted (Esther 4:16). This state of affairs would be "rectified" by later redactors, who wrote addenda to the Book of Esther, including a prayer of hers. We conclude from this that later generations sought out in the Book of Esther the figure of a woman who prayed to God and sought His approval. ${ }^{16}$ But the Book of Esther does not in fact stress any religious facet of her personality, and it would

15 Grintz, ibid. p. 47 ff. See also Y. Licht, "Sefer Yehudit kiyetzira sifrutit", A. Soltman, M.Z. Kadari and M. Shwartz (eds.), Sefer Baruch Kurtzweil (Tel-Aviv, 1975), pp. 169-183 (Hebrew).

16 See Esther in the Apocrypha or (the additions only): A. Kahana, Ha-sefarim Hahitzoniyyim (Tel-Aviv, 1956), I., p. 539 ff. (Hebrew). It should be noted that The Additions to Esther was apparently the most popular apocryphal Book in the rabbinic period and afterwards. See chapter four, below. For a further comparison between the two Books, see: S.Z. Zeitlin, "Ha-sefarim Esther ve-Yehudit - makbila", Beit Mikra, 19 (1974), pp. 337-359 (Hebrew); Carey A. Moore, "The Case of the Pious Killer," Biblical Review, 6 (1990), pp. 26-36. 
be hard to surmise what, if any, this might be, after her years of sojourn in the king's harem. That is, Esther's moral character is totally nonexistent, and her literary portrayal is superficial compared with the character of Judith.

Another distinction must be drawn between Judith and Esther. We must remember that Esther became the deliverer of her people purely by chance, and only through the encouragement of Mordechai. It was her male cousin who brought her to the palace, and pressed her to intercede with the king on behalf her people. Even the single independent, significant act attributed to Esther herself - the writing of the Book of Esther (Esther 9:29) - is really a co-production with Mordechai, after he sent letters out, on his own, to all the Jews (Esther 9:20). Judith, conversely, acted on her own initiative, independently, utilizing her beauty and courage. Esther never risked her own life (though there is such an allusion in the story: Esther 4:11), while Judith endangered herself but managed to escape rape, and rescued her country and city from foreign rule to boot. Esther, then, has nothing in common with the righteous and brave Judith. And indeed, scholars have already noted the oddness of the Book of Esther, though we shall not go into their conclusions here. ${ }^{17}$ It is not inconceivable that the reason that no copy of the Book of Esther has been found at Qumran, where multiple copies of biblical and other books were found, is to be attributed to its incompatibility with the predominant moral outlook of the Jewish people at that time and afterwards. That is, the Book of Esther was found lacking, apparently, not in its omission of the name of God, but rather due to its underlying moral and religious view, which was deemed unfit for inclusion in the

17 E. Bickerman, Four Strange Books of the Bible (Schocken, New York, 1956), pp. $167 \mathrm{ff}$;; M. Bar-Ilan, Polemics between Sages and Priests towards the end of the days of the second Temple, (unpublished) Ph.D. Thesis, Bar-Ilan University, Ramat-Gan, 1982, p. 114 ff. (Hebrew). It should be emphasized that Esther's deed stands out throughout Jewish history as extremely odd; Jewish women as a rule would die rather than be violated by a gentile (see below), while Esther gave herself quite freely. The explanation provided in Esther 2:9 "Esther too was taken into the king's palace" as though she was taken against her will (like Sara in Gen. 12:15). The traditional explanation is that " Esther was taken" - against her own free will' is unconvincing (Targum; Agadat Esther; see: Y. Bachrach, Kitbuni le-Dorot, Jerusalem 1976, p. 47 (Hebrew)). She could have maimed herself, marring her beauty and thus saving her honor. The story of Esther can be compared to another Persian tale, the framework story of One Thousand and One Arabian Nights (a stupid despot manipulated by a woman) or to the Spanish novella "The love story and death of the Jewess Rachel, concubine of the king of Castile" (See: H. Fisch, Poetry With a Purpose: Biblical Poetics and Interpretation (Indiana University Press, Bloomington \& Indianapolis, 1988), pp. 8-14; A. Ben-Gurion, Shvilei ha-aggada (Jerusalem, 1950), p. 133, 243 note 55 (Hebrew), and to the twentieth-century story of the Jewish beauty, mistress of King Carol of Romania. 
canon. The reader of the Book of Esther might mistakenly be lured into thinking no ill of a pious and modest Jewish maiden going of her own free will to the local king's bed, sent there by her cousin, a prominent member of the Jewish community, albeit ultimately to save her people from imminent danger.

It must be taken into account that the Book of Esther is a late composition, reflecting Jewish society in Persia, not necessarily in the Land of Israel; hence it should not be surprising to find major differences between Esther and Judith. It must, however, be noted that Esther cannot serve as role model for any Jewish woman. In sum, it seems that we must point out that, had we the ability to choose only one of the two "women's" books to be included in the biblical canon, Esther or Judith - there is no doubt that the choice would be the Book of Judith. Its portrayal of the female protagonist and its moral values are much nobler than those of the rival book. 18

\section{Tamar, daughter of David, in The Words of Gad the Seer}

The life and rape of Tamar, daughter of King David, are recounted in 2 Sam. 13. We will recall that Amnon, her half-brother, desired his beautiful sister and raped her. Tamar heaped ashes on her head as a sign of mourning for her lost virginity, but there is no mention in the Bible of the king punishing the rapist. Two years later, Absalom, brother of both Tamar and Amnon, cajoled Amnon into accompanying him, plied him with drink, then killed him in revenge for the violation of Tamar.

18 We may draw the following conclusion from this analysis: the reason for the incorporation of the Book of Esther in the biblical canon is not to be found in the book itself, but in external circumstances. The deliberations of the sages over this issue can be found in Megilla 7a, where Shmuel says that "[The scroll of] Esther does not make the hands unclean"; on the other hand, the tannaitic sages said that "Esther was composed under the inspiration of the holy spirit." The latter statement was apparently designed to convince those who said that the Book of Esther was not holy and hence does not defile the hands. That is, just as the Song of Songs was defined as Holy of Holies and was accepted as an allegory, only thus enabling its inclusion in the canon, thus did the Book of Esther become sanctified due to the belief that Esther was a prophetess (Megilla 14a) or that the book is an example of "hidden providence" (following Hullin $139 \mathrm{~b})$. See also modern scholarship: N. Ararat, "Al hiloniyuta shel megillat Esther vetahapuchoteha," Tarbiz, 49 (1980), pp. 223-236 (Hebrew). The religious position of the Book of Esther can be adduced from the talmudic sages' commandment to refer to the Book of Esther as a Torah scroll (as regards copying and reading it), an unparalleled honor. This sanctification of the Book of Esther seems to me to be a means of entering into intentional confrontation with heretical sects. As S. Lieberman remarked: "The rabbis would customarily turn the non-obligatory into obligatory in order to remove any doubts from the hearts of non-believers" (Tosefta Kifshuta, Nashim, 8, New York, 1973, p. 915, Hebrew). 
Though King David had ignored the rape, he must have had a stronger objection to murder, because otherwise Absalom would not have fled from his father to Ptolmey, king of Geshur. This biblical narrative of unrequited love and its tragic consequences became the basis for a different story which appears in an almost unknown book, The Words of Gad the Seer, copied in Cochin, India, in mid-eighteenth century in biblical Hebrew and attributed to the prophet Gad.19 Very little has hitherto been written about this book and its date of composition is uncertain. S.Z. Schechter and I. Abrahams believed the book is a medieval composition, ${ }^{20}$ while I believe it dates from one of the first centuries C.E. ${ }^{21}$ In any case, a long narrative telling of Tamar, daughter of David, appears in The Words of Gad the Seer. In chapter 13 (verses 290-353), we learn that Tamar fled to Geshur after the rape, and there she again fell prey to an attempted rape by Parshaz, one of the companions of the King of Geshur. Tamar succeeded in thwarting his evil intent by playing the harp, thus putting her assailant to sleep. At that crucial moment Tamar invoked God and prayed to Him for mercy and assistance. She then drew the sword of Parshaz from its scabbard, prayed once more, and stabbed him to death. Later on, Bnayahu son of Jehoiada headed a military contingent sent to bring Tamar back home, and she explained to King Solomon that she had run away from him so that she would "no longer be held as a worm in the eyes of the sons of the king my father." And indeed, King Solomon praised her courage and blessed her. Not only is she "a fair and brave woman," but also (verse 350) "henceforth, we will call you sister no longer, but daughter, since you are wise to the utmost." The chapter ends thus: "And King Solomon called his daughter Tamar Tofet after Nataf, the incense, and thus was she called until the end of her days." No other version of this story is extant in any other source, and some clarification is required upon its comparison with other stories. First, the resemblance between our story and that of Judith seems clear. Two Jewish women, each threatened by gentiles

19 Cambridge MS O0.1.20. The facsimile is in the Institute of Microfilmed Hebrew Manuscripts at the National and University Library, Givat Ram, Jerusalem, no. 16265. I thank the administration of the Cambridge University Library and especially Dr. S. Reif for allowing me to publish the manuscript in their possession.

20 S. Z. Schechter, "Notes on Hebrew MSS in the University Library at Cambridge," $J Q R$, os 6 (1894), pp. 13-145; I. Abrahams, "The Words of Gad the Seer", Livre d'Hommage a la mémoire du Dr Samuel Poznanski (edité par le comité de la grande synagogue à Varsovie, Varsovie, 1927 (rep. Jerusalem: publisher not mentioned, 1969), pp. 8-12.

21 M. Bar-Ilan, "The Date of The Words of Gad the Seer", JBL, 109/3 21 (1990), pp. 477493; idem. "The Discovery of The Words of Gad The Seer," Journal for the Study of Pseudepigrapha, 11 (1993), pp. 95-107. 
intent on rape, outwit and overcome him, killing him with his own weapon. Both use their courage and cunning. However, we must make an important distinction between the two. Judith was an independent woman, acting totally on her own initiative, a woman in her own right and not merely the "wife of..." or "daughter of..." Tamar, on the other hand, only responded to a given chain of circumstances; she did not act independently and rescued only herself, not others. It is therefore not surprising that Judith merits an entire book, while only one story, albeit a lengthy one, is devoted to Tamar in her new guise.

The most important comparison is, of course, between Tamar's deed and that of Jael. She, too, killed the enemy (though he was not her personal enemy). And indeed, in her invocation prior to killing Parshaz, Tamar prays (verse 315): "come to my assistance as You came to the assistance of the wife of Heber the Kenite."22 Here we see that the narrator consciously refers to the example of the biblical figure of Jael. Unlike Judith, who fled from the scene of the attack, Tamar, like Jael, remains steadfast and does not leave. Jael (who was not sexually threatened by Sisera) was praised by the prophetess Deborah (Judges 5:24); likewise, Tamar was praised by King Solomon. However, the real issue here is not the similarity between Tamar in The Words of Gad the Seer and Jael or Judith. It is, rather, the affinity between the second Tamar and her biblical namesake, who is presented in the Bible without the complementing account of her subsequent life that is found in The Words of Gad the Seer.

The apocryphal Tamar is shown in an altogether different light from the biblical Tamar. In fact, it is clear that the story before us serves as retroactive "rectification" of the character in the biblical version, in a twofold sense: chronologically, since it was written after the biblical period, and because its plot occurs after the biblical account ends. Evidence of "rectification" of the biblical account of Tamar is found in the story itself. Tamar explains that she fled to Geshur so as not to be held in contempt "as a worm." She fled in order to improve her own self-esteem and her social image. Her success exceeded even her own expectations. Leaving Jerusalem shamed and humiliated (it is ostensibly her own fault that she was raped and not the rapist's); she returns to the city a triumphant heroine. Thus is the biblical Tamar redeemed, and the image of women in general and of Tamar in particular rehabilitated.

22 At the end of the line the scribe inserted a sign resembling this: \#, and it would seem that he, or a later scribe, sensed there was an error in the text. The correct reading should probably be "as you came to the assistance of <Jael> wife of Heber the Kenite." See Chapter Four, below. 
While the text conveys that any woman, even the daughter of a king, is a potential rape victim, the message that the later narrator sought to convey is that any man who tries to rape a woman does so upon peril of death, if not by biblical law, then by the inevitable repercussions. ${ }^{23}$ Furthermore, the woman here is seen to overpower a man, and a prominent royal official at that. This is a slightly different message from that emerging from the story of Judith, who calculatedly accepted the advances of her potential rapist, her personal enemy and enemy of her people. Conversely, Tamar was a victim of circumstances. She was of course in no way to blame for the first rape nor for the second attempted rape. By then, Tamar had learned her lesson, and would not allow the rapist to have his way. This is the author's device for rectifying and rewriting history by re-casting Tamar in a different role from the biblical Tamar. Tamar is no longer only a rape victim; she is capable of standing up for herself. Tamar, then, is more heroic, and undoubtedly presents a significant threat to rapists. Here is a female role model, similar in some respects to Judith. The message is that should a man sexually assault a woman, she should take the initiative, as did Tamar successfully, though she was at the time in the house of a foreign king. The approach found in The Words of Gad the Seer is, then, a more pronouncedly feminist one.

In light of this evaluation, the question of the book's date of composition must be addressed once again; established quite conclusively upon linguistic evidence and the content of parallel accounts. The question is whether this pro-feminist story that upholds the role model of a resourceful, active woman, who is capable of protecting herself against a man's violence, can in fact attest to its date of composition. As stated, there can be no doubt as to the secondary nature of the story, as The Words of Gad the Seer postdates the Bible, and in its "rectification," casts a woman not only as victim of circumstances, but as able to control them (and men as well). However, we must note carefully the narrator's approach. The narrator - a man, presumably - sought to transform the female character from a passive agent to an active one (even if driven only by necessity). He did so not by creating a new, original character but by drawing upon the Bible itself. The very fact that the

23 The biblical example of this is the incident of Dina, the first rape victim in the Bible (Gen. 34). There, too, the rapist was killed, not by the woman but by her brothers, who exacted her revenge on all the townspeople. The girl's father, however, disapproved of this act of revenge. For further discussion of rape in antiquity, see Louis $\mathrm{M}$. Epstein, Sex Laws and Customs in Judaism (Ktav Publishing House, New York, 1967), p. 179 ff;; Alice A. Keefe, 'Rapes of Women / Wars of Men', Semeia, 61 (1993), pp. 79-97. 
narrator tries to emend the Bible would seem to indicate that he lived only a short time after the biblical period. ${ }^{24} \mathrm{Had}$ the author lived much later, the account of the biblical Tamar would not have disturbed him at all, and he would probably have invented a new, fictitious character to carry the role of female protagonist in his book. To be sure, the talmudic sages also engaged in rectification of the account of biblical figures to suit their own needs, but without resorting to biblical literary style, its language and syntax. The rabbinic stories telling of biblical figures are their independent, original literary creation, reflecting newly-emerged aspects of their culture, superimposed upon the old. By contrast, the author who created the story before us couched his account in biblical style, so that it could easily be inserted into the Bible.

Whatever its date of composition, the innovative element in The Words of Gad the Seer is clearly the transformation of the female character from a potential rape victim to an active, independent agent. Tamar's courage is unequal to Jael's, arising as it does out of the threat of sexual attack. Furthermore, the king's daughter can serve as role model to all women, unlike the biblical Tamar or Jael - or Esther, needless to say. Killing the assailant is a new model of behavior for a woman faced with rape, supplanting the passive reaction of being content with screaming, as described in the Bible (Deut. 22:24-27).

\section{Susanna in Additions to Daniel}

The apocryphal writings contain several additions to the biblical Book of Daniel, one of which is the incident of Susanna. ${ }^{25}$ The story purportedly has a simple aim: to show Daniel as a wiser judge than the Elders (cf. Ezekiel 28:3). However, in the judgment providing the context for the demonstration of Daniel's wisdom, the accused is a woman. This reveals the twofold purpose of the story, establishing Daniel's wisdom, and establishing the position of Susanna as a righteous woman. The following is a brief synopsis of the story:

The beautiful Susanna was married to a wealthy Jew of Babylonia. Two elders of the Jews (i.e., sages), who were nominated as judges, lusted after her. They stole into the courtyard of her house where she

24 Another example of this is the author's free usage in The Words of Gad the Seer of Psalms, by inserting the two psalms 144 and 145 into his text, using a different version of the Psalms than the masssoretic text. Likewise, the author of The Words of Gad the Seer rewrites a chapter of Samuel along with its parallel in Chronicles. This would further seem to point to the chronological proximity of this work to the biblical literature, before canonization became an obstacle for such changes.

25 See in the Apocrypha or: A. Kahana, Hasefarim Hahitzoniyim, I, p. 554 ff. (Hebrew). 
was bathing. ${ }^{26}$ The two elders then revealed themselves to the women and tried to seduce her. When she scornfully repulsed them, they threatened her with libel, of adultery with a youth. Susanna was determined that execution was preferable to committing a sin before God. She was brought to court and offered a prayer to God, saying that she had done no wrong. However, the two elders testified against her, and the court found her guilty and sentenced her to death. Just before judgment was carried out, Daniel appeared and convinced everyone that the two elders were perjurers. And thus, through his wisdom, Daniel was able to prove Susanna's innocence and righteousness; her life was saved, and the two elders were put to death for trying to have her killed.

We have here, then, a story of a woman refusing seduction even upon pain of death - no higher righteousness is imaginable. Susanna, then, is a fitting role model for a Jewish woman, demonstrating that it is preferable to die rather than transgress the commandments of the Torah. Moreover, the story shows that God is attentive to the prayers of righteous women and will come to their rescue, as He did for Susanna.

To examine the unique elements in this story, let us compare Susanna and her deed with two biblical figures, a man, Joseph, and a woman, Tamar, daughter-in-law of Judah. ${ }^{27}$ We will recall (Gen. 38) that Judah had sexual relations with his daughter-in-law when she was disguised as a prostitute. When she became pregnant, her father-in-law sentenced her to be burnt to death. As she was led to the stake, she sent Judah articles that he had left with her. Judah realized his mistake and Tamar was saved. From this unwanted pregnancy issued the line of the tribe of Judah, including David, king of Israel — but that is another matter.

Susanna and Tamar, despite their similarity, present two quite different cases. First, the righteous Susanna withstands temptation, while

26 The issue of bathing appears only in the Theodotion version of the incident of Susanna, not in the Septuagint. See also: G. J. Brooke, "Susanna and Paradise Regained," George G. Brooke (ed.), Women in the Biblical Tradition (The Edwin Mellen Press, Lewiston - Queenston - Lampeter, 1992), pp. 92-111. A woman bathing, as an erotic element in the seduction of men, is well-known from the incident of David and BatSheba (I1 Sam. 11:2). According to the pseudo-epigraphical Testament of Reuven 3:11 and the Book of Jubilees 33:2, Reuven lay with Bilha, his father's wife, after he spied her bathing (cf. Judith bathing, ibid. 10,3; 12,7).

27 See Kahana about comparing the incident of Susanna to a Samaritan story. The full text of the story can be found in M.Y. Ben Gurion, Memekor Yisrael, I (Tel-Aviv, 1939), pp. 152-153 (Hebrew). The seduced woman is the beautiful daughter of the high priest, who copied out a Torah scroll in her own handwriting - her father was a scribe, of course. See following chapter. For more parallels and literary analysis see: A. LaCocque, The Feminine Unconventional (Fortress Press, Minneapolis, 1990), pp. 21-30 (however, the claim that the story is "a literature of protest" [p. 1], is not proven. 
Tamar deliberately dresses as a prostitute, and seduces her father-inlaw. ${ }^{28}$ One story is permeated with a God-fearing aura; the other is steeped in forbidden sexual relations (Lev. 18:10). It is clear that even if Tamar merits admiration for succeeding in perpetuating her line, it is Susanna who is deservedly the more appropriate role model for pious Jewish women. ${ }^{29}$

Another character faced with temptation similar to Susanna's is Joseph (Gen. 39). Susanna and Joseph, in Babylonia and Egypt, respectively, resisted the lust of others and did not transgress the prohibition against adultery. Both paid for their steadfastness in the face of temptation; Susanna was nearly put to death, and Joseph was incarcerated. Ultimately, both were rescued. Yet there are two differences between the two. First, Susanna prayed to God to save her (the apocrypha tends to add prayers to stories), ${ }^{30}$ unlike Joseph. ${ }^{31}$ Second, and seemingly most important, is the difference of gender. Thus, whereas the biblical narrative uses the male character to symbolize righteousness and steadfastness in face of temptation, the author of the latter apocryphal story - whether man or woman - introduced a female role model, unmatched by Joseph (indeed in the entire Bible). A man would then be able to admonish his wife or daughter to emulate Susanna, not Joseph. Unparalleled in biblical literature, the figure of Susanna marks the author's success, here as in the Book of Judith, in creating an ideal role model for Jewish women, though we know nothing of its historical reality from preceding or subsequent literature.

28 Indeed, the pseudo-Jonathan translation of Gen. 38:25 includes Tamar's prayer to God. That is, the later author (if this story was indeed read aloud in public: Megilla 4:10), portrayed Tamar as a more religious figure, an attitude similar to that of the author of the Additions to Esther, or the author of the story of Tamar in The Words of Gad the Seer.

29 In Berakhot $43 \mathrm{~b}$ we find a tradition cited in the name of several sages: "It is better for a man that he should cast himself into a fiery furnace rather than he should put his fellow to shame in public. Whence do we know this? From Tamar, of whom it says, 'When she was brought forth,' etc." However, a close reading shows that Tamar humiliated Judah, while Susanna did not act thus, so that Susanna is ultimately superior to Tamar according to this view as well.

30 This tendency to make the protagonist pray is evident also in Chronicles, a later biblical composition. See Chapter Four below.

31 Indeed, the pseudo-epigraphical Testament of Joseph $(6: 7 ; 7: 4 ; 8: 1)$ says that Joseph prayed to God, though the content of his prayer is not revealed. Incidentally, in that same story it is recounted how Potiphar's wife sent food to Joseph with spells cast by witchcraft, portraying her as the evil seductress. In the Testament of Reuven (4:9) these spells are referred to as love potions. 


\section{The circumcising woman}

2 Maccabees 6:10 recounts the story of women who circumcised their sons, carrying out the act by themselves, or instructing men to do so. The Greeks then proceded to kill the women and children. ${ }^{32}$ In this story the author seeks to extol the devout Jews and stress their commitment to the commandments. Furthermore, the story shows that women and men alike would endanger their own lives, in order to uphold the Torah. A parallel account is found in I Maccabees 1:60, but without the extensive detail of the women's courage. Another parallel to this story tells of this unusual and courageous woman.

The Scroll of Antiochus is a re-working of the Books of Maccabees, incorporating additional material unknown to us from other sources. ${ }^{33}$ The Aramaic composition was habitually read aloud in some communities, despite its non-canonical apocryphal status and the fact that it is not included in talmudic literature. The conjectured date of its composition is the second century C.E.; at any rate, it does not postdate the Books of Maccabees. This slim volume went largely disregarded and unstudied. (It has now appeared in a new Hebrew translation by M.Z. Kadari):

So drastic was the king's edict that when a man was discovered to have circumcised his son, he and his wife were hanged along with the child. A woman gave birth to a son after her husband's death and had him circumcised when he was eight days old. With the child in her arms, she went up on top of the wall of Jerusalem and cried out: "We say to you, wicked Bagris, this covenant of our fathers which you intend to destroy shall never cease from us nor from our children's children." She cast her son down to the ground and flung herself after him so that they died together. Many Israelites of that period did the same, refusing to renounce the covenant of their fathers. ${ }^{34}$

32 Regarding the possibility that women circumcised their sons by themselves (and that the mention of men was only added by a later scribe) as there was no obstacle for women acting thus, see Yebamoth 64b: "If she circumcised her first child and he died... she must not circumcise..." See also: M. Bar-Ilan, Polemics (above note 17), p. 176. For the falasha custom, see A. Epstein, Mikadmoniyot ha-yehudim, I, Jerusalem, 1950 (Hebrew), and see below. It is clear, however, that circumcision was in those days a masculine rite of passage (Gen. 34:15; Josh. 5:2 ff). The ceremony excluded women. For the medieval sources on this question, see: Y.S. Spiegel, "Ha-isha ha-mohelet - ha-halakha vegilguleha ba-SMG," Sidra, V (1979), pp. 149-157 (Hebrew). For an anthropological view see: N. Rubin, Reshit Hahaim (Tel-Aviv, 1995), p. 16-17 (Hebrew).

33 N. Fried, "Minhagim lo yeduim batefila," Tagim, II (1971), pp. 109-122 (Hebrew). The book under discussion is not included in the Charlesworth edition, and only few scholars have extracted historical facts from it.

34 Scroll of Antiochus in: Daily Prayer Book, translated and annotated by Philip Birnbaum (Hebrew Publishing Company, New York, 1969), pp. 786-788; M.Z. Kadari, 
If we compare this story to the account in the apocryphal Maccabees, we can see how the author extols the courage of a brave woman and upholds her as a model of behavior for all. As we have stated, the historical authenticity of this story and of the others treated here is of only secondary importance. For us, their importance lies in the portrayal of a Jewish woman who dared defy the king in order to avoid transgressing against God's commandments. That is, whereas the heroines Judith and Tamar exhibited physical courage in killing their assailants, we now have a courageous woman who was willing to lay down her own life for the precepts of the Torah, after the fashion of Susanna. However, in this case, she was prepared to sacrifice not only her own life and die a martyr's death, but that of her son as well.

We must examine this instance of bravery, especially in relation to the act of Zipporah, wife of Moses (Gen. 4:24-26). She, too, courageously circumcises her son, yet there is a great difference between the two cases. Zipporah saved her son from death by circumcising him on her own initiative, even though her husband was present. ${ }^{35}$ The anonymous woman in Maccabees, on the other hand, was a widow, and apparently acted with the opposite intention: following the act of circumcision, she immediately put him to death. What is the meaning of this paradox?

It seems that in the account of Zipporah's deed, it is the counterdemonic function of the act of circumcision that comes to the fore. Zipporah was not motivated primarily by religious law, in the strict sense of the word, but acted chiefly to save her son's life from a terrible fate that God might mete out to him. Her resourcefulness is matched by that of the woman from Shunem 2 Kings 4:21-27). As a rule, women cared for the newborn infant, severed the umbilical cord, nursed and clothed him, so it is not at all surprising that they also removed the

\footnotetext{
"Megillat Antiochus ha-Aramit," Bar-Ilan, I (1963), pp. 81-105 (Hebrew). Kadari demonstrates that the work was at least partially an independent venture; Fried shows that the Book includes details that are not known from any other source. See also A. Kasher, "Ha-reka ha-histori le-hibura shel Megillat Antiochus", B. Bar-Kochva (ed.), Ha-tekufa ha-selevkit be-Eretz-Yisrael (Tel-Aviv, 1980), pp. 85-107 (Hebrew).

35 We know that the biblical translations, the tannaitic sages, and the commentators differed as to the interpretation of the words "and sought to kill him" (Ex. 4:24). Did the angel seek to kill Moses or the infant? See Nedarim 32a; Mekhilta de-R. Ishmael, Jethro 1, ed. Horowitz-Rabin,2 (Jerusalem, 1970), p. 191. However, I refer here to the plain sense of the text, which is that one who is uncircumcised is forbidden to pass and the angel is permitted to punish him. See: M. Bar-Ilan, "Magic Seals on the Body among "Jews in the First Centuries c.E.," Tarbiz, 57 (1988), pp. 37-50 (Hebrew). For views of Zipporah's act as magic, and for other aspects of the story, see: B.S. Childs, Myth and Reality in the Old Testament (SCM Press, London, 1962), pp. 59-65; Clarence J. Vos, Woman in Old Testament Worship (N.V.Verenigde Drukkerijen Judels \& Brinkman, Delft [1968]), pp. 133-144; Athalya Brenner, The Israelite Woman, p. 71.
} 
foreskin. ${ }^{36}$ The only cause for surprise in this context is that God commanded Abraham to observe the covenant of circumcision, whereas here, it is the mother and not the father - although he was present who observed the commandment.

There is a certain resemblance in our present account between Zipporah and the circumcising woman, who was also trying to save her son from disaster, albeit of a different kind. She feared that her son would not be a Jew (and as a consequence would be barred from eternal life in the hereafter). ${ }^{37}$ The two women, then, did not primarily intend to carry out a religious duty, but, rather, acted chiefly to save their sons, whether from immediate danger in this world or in the hereafter. This becomes clear when, following the circumcision, one woman killed her son, in a premeditated, calculated way and not in a fit of madness, to prevent the enemy from seizing her son and raising him as an idolater. The obvious conclusion is that both women acted courageously and each observed the commandment of circumcision.

The reader is presented with an instance of female courage carried out at the forefront of religious life and not in the context of the war between the sexes, although the latter is still the primary scene of conflict, since the decree forbidding religious observance is issued by male authority. It then becomes clear that we have a female role model in the ancient struggle of the Jewish people for survival, setting an example for observance of the Torah and its commandments. We should also note that this incident is not inherently different from the act of the king of Moab, who sacrificed his own son (2 Kings 3:27). In both cases, a parent kills his or her own son, due to the parent's belief in his or her god; the difference lies in the religious outlook of the narrator reporting the incident. ${ }^{38}$ The resulting image, then, is not of a monstrous figure committing infanticide, like goddesses and mythical women. ${ }^{39}$ The mother is commended for her admirable behavior as a

36 On midwives who circumcised a dead infant, see S. Lieberman, Texts and Studies (Ktav, New York, 1974), p. 266.

37 It should be noted that the formulation of the obligation to circumcise a stillborn infant before his burial dates only from the ninth century. However, an analysis of the early incident at hand (dating from the second century C.E. at the latest, if not the second century в.C.E.), shows that the practice was common centuries before any literary evidence of it. This is hinted in the words of R. Levi in Gen. Rabbah 38:8, ed. TheodorAlbeck, p. 483.

38 In both cases the author expresses his admiration for the acts, though the primary references in the Bible for denunciation of the sacrifice of human children are found elsewhere (for instance, Deut. 18:10).

39 The image of the woman as monster/witch/committer of infanticide/evil, etc., has been treated in the psychological study of E. Neumann, The Great Mother, 2nd ed. 
Jew in times of religious persecution. Let us add that the woman in our story represents the pinnacle of religious devotion, and dies a martyr's death sanctifying God's name, all the while caring for her family; but a talmudic parallel tradition contains contrary themes. In Tosefta Sukkah 4:28 we read of "Miriam, daughter of Bilgah, who apostasized. She went off and married an officer of the Greek royal house. And when the gentiles went into the sanctuary, she came along and stamped on the altar." So, while in The Scroll of Antiochus we see that a woman serves as model for sanctifying God's name, in talmudic literature this role is filled by male figures (Rabbi Akiva, for instance), and a woman is cast in the role of blasphemer. The relation of the apocryphal The Scroll of Antiochus to talmudic literature is unclear: the former portrays a woman as an ideal religious model, whereas talmudic literature presents a woman in the opposite light. ${ }^{40}$

\section{The Woman (Hannah) and her Seven Sons}

4 Maccabees, 8:3 ff. tells of the martyrdom of an elderly priest, Eleazar, and of a woman and her seven sons. ${ }^{41}$ In that account, Antiochus issued a decree forcing Jews to transgress the commandments of the Torah. They chose to undergo great tribulations and painful death rather than obey the king. At first he forced an old man to violate the commandments; when the man refused, the king tortured him to death. Next, an old woman and her seven sons were brought before the king, and he tried to force them to violate the commandments by means of temptation, threats and torture. But the youths stood fast and died a cruel death. The mother herself encouraged her sons to choose death over

(Pantheon Books, New York, 1963), pp. 147 ff. See also Walter H. Wagner, "The Demonization of Women," Religion in Life, 42 (1973), pp. 56-74, and see chapter five, below.

40 It should be noted that the author does more than emphasize the woman's bravery; he goes on to denigrate the man's heroism. According to the Scroll of Antiochus, Eleazar the Maccabee was not killed in attempting to stab the elephant; he drowned in the elephant's excrement! - a most humiliating death (see b. Gittin 57a). Perhaps a feminine thread runs through these two stories, and the Aramaic one (more familiar to women than the Hebrew version, see Megilla 4:10) strengthens this opinion, but provides no conclusive evidence. On the different criteria for defining feminine literature, see also the chapters below on literacy and keening.

41 Y. Gutman, "Ha-em ve-shivat baneha ba-aggada u-vesifrei Hashmonaim II ve-IV," M. Schwabe and Y. Gutman (eds.), Sefer Yochanan Levi (Jerusalem, 1949), pp. 25-37 (Hebrew); G.D. Cohen, "Maase Hannah ve-shivat baneha basifrut ha-ivrit", M.M. Kaplan Jubilee Volume (New York, 1953), Hebrew section, pp. 109-122 (Hebrew); Galit Hasan-Rokem, Rikmat Haim (Am Obed, Tel-Aviv, 1997), pp. 128 ff. (Hebrew). 
violating the Torah. Finally, as the executioners led the woman to her death, she herself jumped into the fire.

This familiar story entered Jewish tradition via various midrashim that summarized the Books of Maccabees and extolled the bravery of the woman (in later literature she is named Hannah) and that of her sons. This story merits special attention. This account and the previous account of the circumcising woman are of similar origin. In both, the woman takes her own life rather than fall into the hands of the enemy of her people and her faith. However, while in the previous example the mother puts a son to death, here a mother watches seven of her children being executed. This woman, who stands steadfast in face of a cruel, sevenfold temptation, is more courageous than the one who is tempted only once. The author's intention is clear: he wanted to show that a woman, and not only a man, can be a heroine and a martyr sanctifying God's name. This is stated explicitly (16:2): "I have proven, accordingly, that not only have men triumphed over their sufferings, but that a woman also has despised the most dreadful tortures." We see that the author here states clearly what is only implied in the circumcision story: i.e., a woman here sets an example as an ideal role model for Jewish women in similar circumstances. The stylized martyr figures sanctifying God's name underscore the author's idealization: an old man, then a widow with her seven sons. The author reports that all were buried in a common grave, and it would seem that he purposely did not designate the woman as "wife of", which would have detracted from her status as an independent woman acting on her own initiative.

The authorial intention of stressing that a woman, and not only men, can serve as role models recurs again later. The martyred woman has an encounter with the Patriarch Abraham, who has also been put to a similar test. The author was, of course, aware of this, as we see from his explicit mention of Abraham's experience. Abraham was bidden to sacrifice his son (Gen. 15:58; 16:20), but was then reprieved. The latterday redactor of the story has the woman speak the words that draw a clear comparison between her own act and Abraham's. Abraham was told to sacrifice only one son, which he did not really do; she actually sacrificed seven sons. ${ }^{42}$ This woman's bravery, then, is greater than that of the Patriarch Abraham. The author extols the woman as an ideal

42 Cf. Lamentations Rabbah 1:50: "The mother threw herself upon her child and embraced and kissed him. She said to him, 'My son, go to the patriarch Abraham and tell him, 'Thus said my mother, Do not preen yourself [on your righteousness], saying I built an altar and offered up my son, Isaac: Behold, our mother built seven altars and offered up seven sons in one day. Yours was only a test, but mine was in earnest."' 
figure, above and beyond any previous concept of women, exceeding even the biblical example. The courage of a God-fearing woman could now serve as example to men and woman alike, in a world that persecuted observant Jews. It must be noted that no physical courage is seen here, comparable to Judith and Tamar overpowering the assailant, nor is there any sexual threat like the one Susanna faced. We have, then, a more powerful incident even than the circumcision story. We have an example of the highest level that a God-fearing spirit can attain.

There is no doubt that the description itself is literary rather than historical. ${ }^{43}$ It is also clear, however, that such literary descriptions would serve no purpose had there not been real women (and men) who chose to die rather than commit idolatry. In any case, even if the specific historical details remain vague, the story as a whole has an unmistakable didactic import. The Jewish readers - and women in particular - learn from the story how their foremothers chose death in order to uphold the Torah. The death of Hannah and her seven sons was seen by many as the exemplar of the sanctification of God's name, no less than the sacrifice of Isaac.

\section{Talmudic literature}

\section{The girls who jumped into the sea}

There are very few stories of female courage in talmudic literature, and these, too, are really stories of suicide, thereby of a questionable degree of courage. In any event, the following tradition is included among the legends telling of the destruction of the Temple (b. Gittin 57b):

Rab Judah said in the name of Samuel, or it may be R. Ammi, or as some say it was taught in a Baraitha. On one occasion four hundred boys and girls were carried off for immoral purposes. They divined what they were wanted for and said to themselves, If we drown in the sea we shall attain the life of the future world. The eldest among them expounded the verse, "The Lord said, I will bring again from Bashan. I will bring again from the depths of the sea." (Psalms 68:23) "I will bring again from Bashan, from between the lions' teeth. I will bring again from the depths of the sea," those who drown in the sea. When the girls heard this they all leaped into the sea. The boys then drew the moral for themselves, saying, If these for whom this is natural act so, shall not we, for whom it is unnatural? They also leaped into the sea. Of them the text says, "Yea, for Thy sake we are killed all the day long, we are

43 True, the author imparts authenticity to his story by describing the martyrs' tombstones, but the literary stiffness of his account (presented here in much abridged form), as also the typological number of children - seven, indicating perfection and holiness, show that this much-edited version does not reflect a "true" story. 
counted as sheep for the slaughter" (Psalms 44:23). Rab Judah, however, says that this refers to the woman and her seven sons.

This literary tradition would seem to be grounded in historical reality. From the time of Saul onwards, many instances are known of Jews (and non-Jews) who endangered their own lives rather than be taken captive by the enemy. ${ }^{44}$ The unique element in the present story is that, unlike the circumcising woman and the woman with seven sons, in which one woman appears with one or several children, here we have an exemplary deed of a group of girls acting in unison. Moreover, women here set an example to men in their behavior, though we are dealing here with children. 45

However, the children's courageous deed is not unflawed. Since they acted as a group, one might ascribe the deed to mass hysteria rather than to true courage. Neither was this courageous act witnessed by the king or other onlookers, as it took place at sea. The captain of the ship that the children were bound for might have thought it was an accident, or, at any rate, could have presented it in that light to his superiors.

It is also to be noted that this account of martyrdom deals with an equal number of male and female participants, an unusual literary symmetry in talmudic literature, which preferred men as exemplary characters of martyrdom. The famous legend of the Ten Martyrs, for instance, recounting the deaths of the sages, does not include even a single woman. ${ }^{46}$ Moreover, we should evaluate the literary presentation of women in tannaitic literature and in the ammoraitic material, on the one hand, and compare it with the characterization of women in the apocryphal writings (which only entered the talmudic world later), on the other hand. The following example is from Sifre on Deut. 324, par. 307:

44 M. Stern, "Hitabdutam shel Elazar ben Yair ve-Anashav vehaphilosophia harevi'it," Zion, 47 (1972), pp. 367-398 (Hebrew). (ibid, p. 380 tells of the Cimber women who killed their children and then committed suicide in 102 B.C. See ibid. p. 392 note 136 about Jewish women who slaughtered their children during the Crusades.

45 The parallel to this story in Lamentations Rabbah, 1,45 makes no mention at all of men, and the women committed suicide in three groups (for heightened dramatic effect). The author apparently could not tolerate the idea that men would follow the example set by women.

46 Much has been written about the Ten Martyrs; for the present discussion, see S. Kraus, "Asara Harugei Malkhut," Hashiloah, 44 (1925), pp. 10-22; 106-117; 221-238; Y. Dan, "Pirkei Heikhalot Rabbati u-maase aseret harugi malkhut," Eshel Beer Sheba, II (1980), pp. 63-80. See also S. Lieberman, "Redifat dat Yisrael", Salo Baron Jubilee Volume, Hebrew section (Jerusalem, 1975), pp. 213-245. 
When they apprehended R. Haninah ben Teradion, he was condemned to be burned together with his Torah Scroll. When he was told of it, he recited this verse, "The Rock, His work is perfect." When his wife was told, "Your husband has been condemned to be burned, and you to be executed," she recited the verse "A God of faithfulness and without iniquity." And when his daughter was told, "Your father has been condemned to be burned, your mother to be executed, and you yourself to be assigned to (disgraceful) work," she recited the verse, "Great in counsel, and mighty in work, whose eyes are open (upon all the ways of the sons of men, to give every one according to his ways) (Jer. 32:19). ${ }^{47}$

So we see that whereas the circumcising woman, the mother of seven sons, and the group of girls all commit suicide rather than fall into the hands of the enemy, these are all pre- or post-tannaitic literary traditions; while the talmudic literature itself paints a different characterization of women. After the Bar Kokhba revolt, there were women who did not choose suicide over the fate their enemy decreed for them. Needless to say, they could not, like Samson, proclaim "Let me die with the Philistines" (Judges 16:30), since women are not possessed of Samson-like physical strength. However, neither did they commit suicide like the women in the story quoted above, though a certain woman, the daughter of a rabbi, (Beruria, perhaps?), knew that she was to be sent "to work," a euphemism for prostitution (cf. Abodah Zara 18a). ${ }^{48}$ In a word - there are almost no heroines at all in tannaitic literature.

\section{Women spurning Roman legionnaires}

\section{Y. Sukkah 5:1, 95b presents the following "feminine" story:}

In the time of Tronianus, the evil one, a son was born to him on the ninth of $\mathrm{Ab}$ and [the Israelites] were fasting. His daughter died on Hanukkah, and [the Israelites] lit candles. His wife sent a message to him, saying "Instead of going out to conquer the barbarians, come and conquer the Jews, who have rebelled against you." He thought that the trip would take ten days, but he came in five... His legions surrounded them and killed them. He said to the women "Obey my legions, and I shall not kill you." They said to him, "What you did to the ones who have fallen do also to us who are yet standing." He mingled their blood with the blood of their men, until the blood flowed into the ocean as far as Cyprus. At that moment the horn of Israel was cut off, and it is not destined to return to its place until the son of David will come. ${ }^{49}$

47 Sifre Deuteronomy, translation with introduction and notes by Reuven Hammer (Yale University Press, New York and London, 1986).

48 This tradition is discussed in D. Goodblatt, "The Beruria Traditions", JJS, 26 (1975), pp. 68-85. Cf. the discussion in Chapter Six, below.

49 The Talmud of the Land of Israel, translated by Jacob Neusner (Chicago and London: University of Chicago Press, 1988), vol. 17. The variant followed here is that of Palestinian Talmud Leiden MS (Kedem, Jerusalem, 1971), II, p. 571. The story has a 
Thus, the Palestinian sage believed that Trajan's wife cajoled him to kill the Jews of Egypt (117 c.E.). Then, after Trajan killed the men, he ordered the women to obey his soldiers, to surrender to their sexual demands, as was habitual for female captives. However, the women apparently hid in the local synagogue (as was often done in Europe in the Middle Ages). After the men were killed on the ground floor, they told Caesar: Do to those higher up, i.e., the women of the top story, as you did to those lower down, i.e. to the men on the ground floor, in other words, kill the women too. ${ }^{50}$ For our purpose, the importance of the anecdote lies in the fact that Jewish women refused sexual relations with the Romans, and although they lacked the courage to take their own lives, still they were killed for their show of bravery.

Unlike most tannaitic material, this story is not written in Hebrew; it contains numerous Aramaic interjections. The previous stories of the circumcising woman and the drowned girls are also extraneous to the tannaitic material. The tannaitic stories are in a different tone altogether. This issue requires further attention. In any case, these aweinspiring stories of women martyrs sanctifying God's name in the ancient world end the chapter of female bravery in the Second Temple period and its aftermath. ${ }^{51}$

\section{The social aspect}

This gallery of heroines, extending from the Bible into talmudic literature, displays the nuances of the characterization of the Jewish

parallel in Midrash Lamentations Rabbah, 1, 48. The significant textual variation is: "do on the ground what you have done above." However, the reversal in this variant: "do on the ground..." is difficult, see following note.

50 This interpretation of "high" and "low" as relating to the structure of the ancient synagogue, where (some believe) women prayed in an elevated enclosure, was accepted by Sukenik and Swidler. See Prayers by Women, Chapter Four below, and L. Swidler, Women in Judaism: The Status of Women in Formative Judaism (Scarecrrow Press, Methucn NJ, 1976), p. 90.

51 See also Pesikta Rabbati, 26, ed. M. Ish Shalom (Vienna, 1880), p. 131, where we read that at the destruction of the First Temple, priests and levites would set fire to themselves in sympathy with the burning Temple, just as "when the maidens weaving the canopy (parochet) saw the Temple burning they fell into the fire and were burned, so as not to be tortured by the enemy." It is almost certain that this passage is an allusion to 1 Baruch 10:10-18. Cf. also "Midreshei Hannukka" in Grintz, pp. 196-208, some of which derive from the Book of Judith, and see Sheiltot of Rav Ahai Gaon, ed. S.K. Mirski, I, Jerusalem, 1961, p. 198 (Sheilta 27) Hebrew. On women martyrs in the Middle Ages, see: S. Novle, "The Jewish Woman in Medieval Martyrology", Ch. Berlin (ed.), Studies in Jewish Bibliography History and Literature in Honor of I. Edward Kiez (Ktav, New York, 1971), pp. 347-355. 
heroine over different periods. The Bible mentions only a few women, heroes in general are rare in apocryphal writing, and only male Maccabees are acclaimed as heroic. It would seem that that age preferred to locate a man's courage in the mystic sphere, that is, in his spiritual, not physical qualities. It is precisely in this milieu that the unique elements in the post-biblical accounts of female courage can be seen. Not only do heroines outnumber the men, but their courage surpasses that of biblical male and female heroic figures alike. The post-biblical literary tradition of female heroism may cast women in a heroic role, and even intensifies the degree of their courage.

The altered description of women probably reflects the rise of the status of women in Jewish society. However, it seems that it is not the authors who set out to improve women's characterization, but the women themselves. They subjected their previous literary portrayal to a process of rectification, and supplanted men as exemplary heroic figures. The role models are no longer Abraham and Joseph, but Susanna and the mother of seven sons; not the deceitful Ehud son of Gera, who killed the gentile ruler, but Judith, who was not a judge but nevertheless delivered her people from danger. Women thus supplanted the long-standing male heroic figure that is so familiar to us from the Bible. Not only do women play the "male" role; they also amend and rectify the portrayal of the female biblical figures. Tamar, raped in the biblical account, now attacks her assailant, demonstrating how far removed she is not only from the biblical Tamar, but also from Dina and her other biblical sisters. The depiction of the circumcising woman is also intended to correct the impression made by Zipporah, who in the Bible carried out the act of circumcision, since the latter woman wins eternal life for her son. This, then, is the import of these stories: rectification and amendment of female characterization, reflecting perhaps a new social norm. In addition to the innovation of women becoming role models, men are now presented in a negative light. The only thing they want is to rape women, at least in the stories of Judith, Susanna and Tamar. The author wanted to call to the reader's attention that rapists are found even in higher social strata, including high-born and royal aristocratic men such as Amnon, son of the king of Israel, and Hamor, son of Schechem the Hivite, chief of the country, or Parshaz, a courtier of the king of Geshur. Ridicule reaches its height in the incident of Susanna: even the most learned men are cast as lecherous adulterers who lose all power of reason and end up committing perjury. In biblical accounts (with the exception of Gen. 22:15) women play the role of seductress and are the ones to lead the men astray, from Eve to the 
daughters of Lot and Potiphar's wife, to Solomon's wives and Job's wife. In later literature, men are cast in the role of leading women astray. ${ }^{52}$ The reader then is introduced to a courageous and positive woman, and simultaneously with a negative male character.

The analysis of the literary issues raised above leads to the conclusion that we are justified in viewing these compositions as "feminine" literature, or at least early intimations of it. We can also ask whether women themselves actively wrote in this genre that describes women in a positive fashion unparalleled in the Bible (even in the Book of Ruth). ${ }^{53}$ The relevance of this issue changes, of course, from one character to the next. In actual fact, the only book that would be a candidate for consideration as "feminine" literature is the Book of Judith, since all the other characters treated here are secondary to the main events. With the exception of Judith, all the other characters described above could easily disappear from the book, and their disappearance would go unnoticed. The plot in the book of Judith revolves around her, and without her there would be no plot at all. Might we be justified, then, in attributing the composition of the book of Judith to a woman?

On one hand, it is difficult to assume that a woman could write any Book at all in antiquity. We must remember that writing a book, as it still is today, is the culmination of an extended educational process in which the student acquires writing skills. At first the future writer learns to transcribe, then he begins to compose short pieces of his own, and only after the whole of the educational process can he pen an entire book. Since the number of literate women in antiquity was negligible, it would indeed be most doubtful if any woman completed such a rigorous curriculum. ${ }^{54}$ Aside from the "feminist" nature of this composition, it displays an odd stance towards halakha and society. ${ }^{55}$ The Book of Judith has preserved laws and concepts that appear in almost no other Book. This Book represents a non-mainstream, sub-category of society in Land of Israel; if this is so, perhaps women there were educated and could attain some level of literacy as reflected in the Book

52 But, cf. the negative portrayal of women in the Book of Ben-Sira, perhaps a tradition of wisdom literature. See Warren C. Trenchard, Ben Sira's View of Women: A Literary Analysis (Brown Judaic Studies 38, Scholars, Chico, 1982).

53 S.D. Goitein, Iyyunim bamikra,3 (Tel-Aviv, 1967), p. 248 ff. (Hebrew).

54 See Chapter Two, below, on literacy among women.

55 A. Buechler, "Hearot ve-haarot al matzav ha-isha besefer Yehudith", Vezot leYehuda: Anthology of articles in Jewish Thought in Honor of Yehudah Aryeh Blau, Z. Hawashi (ed. et al., Budapest, 1926), pp. 42-65 (Hebrew). (The name of this article is misleading; it should more properly be called Early Halakha in the Book of Judith). 
of Judith. We have, however, no external evidence that a woman wrote the Book, and the question must remain unanswered.

We have established the newly-found significance of those later accounts of female courage that are without biblical parallel; let us now turn to see what remains lacking in the literature we are treating. It seems that the partial answer is that the stories discussed here portray no woman along the lines of the valiant model described in Proverbs 31. There is no attempt to cast a woman in the mold of the ideal homemaker: raising children, caring for her husband, advising him wisely, rescuing him from death, or preventing him from transgressing against the commandments of the Torah. Neither are these women depicted as engaged in "womanly" activities such as weaving. The heroine is conceived of as a woman threatened by men in extreme situations of a sexual or physical-religious nature. The reality depicted in these stories is extraordinary, not ordinary, daily situations and behavior (such as diligence, confidence, amassing wealth, etc.) Needless to say, it never entered the mind of the writer - whether male or female - to describe women's excellence in the administration of the royal court or the temple, since the modern concept of equal opportunity was totally foreign to all in the ancient world.

If a woman is to serve as role model for men as well, it follows that the authors of these stories believed that as a rule, a woman cannot set an example unless she is in a life-threatening situation. Indeed, the preferred situation is of a woman walking to her death. This is really a parody of courage - admiring a woman only a moment prior to her death, but not a second earlier.

We must ask what is the significance in that all the stories of courage discussed here derive from apocryphal writings and not from tannaitic literature, and that courageous women are not mentioned in talmudic literature. Could this be attributed to an anti-feminine bias on the part of the sages of the Mishnah? Why did they fail to extol the character of a single heroine, while the apocryphal sources present us with five such women? Ammoraitic literature, too, has an account of a group of heroines. The ration of five to nothing seems to indicate, despite the general rule against drawing conclusions ex silencio, that the tannaitic sages did not award any positive value to the female heroine. Apparently, they thought these women should rather have stayed at home and not have introduced themselves into situations that necessitate courage in the first place. ${ }^{56}$ According to this approach, Judith should have remained at

56 This approach is formulated later by Maimonides in Hilkhot ishut 13, 11: "For every woman is entitled to go to her father's house to visit him... For she is not in a 
home - and left the fate of the city in God's hands. Tamar, too, should have stayed in her father's house, then she would never have fallen victim to a second attempted rape. The same would hold true for the other women: they brought upon themselves the event that ultimately led to their act of courage - but had they been wiser, they would never have reached that stage. However, since such an outlook has never been explicitly formulated in talmudic literature, we must leave this, too, as an open issue. In any event, the story of the daughter of Rabbi Hananya ben Tradion is most instructive in this respect, showing how a tannaitic source introduces a passive woman (as in the drowned girls' collective suicide), while we find an energetic, positive depiction of women in the accounts of similar ideological content.

It must be added that even women's heroism deemed worthy of mention is presented in cautious, not unduly generous fashion, always remaining within the confines of the "womanly norm." For this reason, it seems, we will search in vain for a woman seizing a dagger and setting out for the battlefield. Three of the heroines possess the "feminine" quality of beauty, and their courageous acts include nothing that a man could not do. In fact, the woman is the heroine of circumstances created by men. Men are to be held accountable for turning women into heroines, not women's own nature. ${ }^{57}$ Neither is there any account of a woman taking up arms against another woman, which would seem unnatural. ${ }^{58}$ The author - whether man or woman — seems to have

prison where she cannot come and go... It is unseemly for a woman to be constantly going out abroad and into the streets, and the husband should prevent his wife from doing this and should not let her go out, except once or twice a month, as the need may arise. Rather, the seemly thing for a woman is to sit in the corner of her house, for so it is written, "All glorious is the king's daughter within the palace" (Ps. 45:14); (The Code of Maimonides, translated by Isaac Klein, Yale University Press: New Haven and London, 1972, vol. xix). Compare the reference to prison with the curses heaped on Eve (and all her daughters forever) in The Fathers According to Rabbi Nathan (translated by Judah Goldin, New Haven: Yale University Press, 1955, p. 9), "as though she were bound in prison and banned from all men." See also Tosefta Sota ch. 5 hal. 9: “...like Pappos b. Judah, who used to lock his door to keep his wife inside."

57 Of. the Dutch folktale of a child who saves the village by sticking his finger in the dike. It is significant that a child is the hero, not a woman or a man, and he faces a natural disaster, not a man-made one. The literary parallelism is: child/nature; woman $/ \mathrm{man}$. We do not possess a story of a woman battling the forces of nature like the wise woman who managed to make the locusts disappear, whose righteousness brought the rains, and whose bravery rescued a man from a landslide, etc.

58 On Amazon-like women warriors, see Sefer Hayashar, ed. E. Goldschmidt (Berlin, 1923), p. 135 (The men of Arbelio and their wives went to battle against the sons of Jacob). According to the tannaitic sages, the Torah forbids women to take up arms and go to war. See Deut Rabbah, ed. Finkelstein, p. 258 and parallels. Another example from antiquity is women gladiators fighting each other in Rome, a fight enforced by men for 
understood that a woman would not battle against one of her own sex and status. Women are seen as sisters-in-arms; if they do fight, it is against men and their authority.

These accounts of courage are stories of women acting independently in the wider world, after their calm existence is disrupted by men. Their personal status reflects their independence: of the five women discussed here, one is certainly a widow (Judith), and it seems that the old woman who appears before the king with her sons has no husband and is a widow as well. Perhaps the circumcising woman is also a widow. Her husband, at any rate, is not present at the event. Of the five women, then, one is married, one betrothed, two are widows, and one acts without her husband by her side. The figure of the widow does not attest to any act of defiance on the part of the widows against their social standing, as might be the impression received. The widow is an independent woman who runs her household, heads her family and manages her affairs independently, and thus takes the initiative and acts more independently than a woman who is dependent on husband or father. In this fashion we can explain the difference between Tamar and Judith, that is, two heroines performing identical deeds; nevertheless, Judith acts independently and is not obliged to wait on the favors of any man: neither enemy, nor relative nor fellow Jew. In this respect one might surmise that one reason for Judith not marrying a second time was her fear of a man taking over her life, putting an end to her independence and resourcefulness.

Women in these stories are not merely beautiful or heroic, but pious, praying believers. Continuity is preserved with the biblical account of Hannah's prayer (1 Sam. 2) and even with the Song of Deborah (Judges 5 ). The women emerge not only as serving their husbands; but also as pious Jews in their own right with the ability to address God and formulate a prayer, thus enhancing their exemplary standing. These figures are fit to be emulated by any Jewish woman hearing or reading these stories. They can identify with the heroine both on the behavioral and the religious levels. In the world of the talmudic sages, however, these views are almost entirely absent; there are no heroines, and almost no formulation of women praying has been preserved. ${ }^{59}$ Women lived in a cruel world in antiquity, as they do even today to a certain degree. They were subjected to the authority of foreign rulers and enemies, as were their husbands, fathers and children, but they were in double danger, from men in general, and their own kinsmen

their own entertainment.

59 For more on women praying see Chapter Four, below. 
among these. If they were not raped, they could fall prey to libelous accusations of lechers, and it was not impossible that women were put to death following perjury by men.

\section{Conclusion}

In the Second Temple period the status of women underwent a transformation that is reflected in the literature of the time. The historical truth of any given story discussed here is of only minor consequence; our primary interest is the message to the reader or audience contained in each story. These stories reflected changing attitudes and conveyed a different message than previous accounts. The stories served to correct the image of women as it emerged in biblical literature. Women were no longer beautiful though passive; they were now beautiful and heroic, delivering themselves and their people from danger. They were also pious and prayed to God. This combination of qualities does not necessarily mean that women changed, but rather that women's self-image and male perception of them changed. They were much better suited to serve as role models for women than the biblical accounts. A Jewish woman could henceforth identify easily with Judith and Tamar, with Susanna and with the martyred women, more than with Esther or other female biblical characters. ${ }^{60}$ This can be seen as a small-scale revolution: the transformation of the image of women and of their status in Jewish society in the post-biblical period. It remains to be seen why this approach towards women left no mark whatsoever on the tannaitic literature, which makes no mention of even a single woman who could serve as role model.61 It seems that the oral law perpetuated the biblical outlook so that the status of women was not improved, while the apocryphal writings led to an improvement in the actual status of women. ${ }^{62}$

60 On heroines in a later period, see S. Ashkenazy, Neshei Israel begevuratan (Tel-Aviv, 1990), pp. 23-26 (Hebrew).

61 Cf. also Y. Elboim, "Demuyot nashiyot ba-aggadot hazal - model lehikuy," Hagut Anthology of Jewish Thought, Women in Jewish Sources (Ministry of Education and Culture, Jerusalem, 1983), pp. 13-26 (Hebrew).

62 On the misogynist approach of the sages see Chapter Five, below, and see also M. Bar-Ilan, "The Occurrance and Significance of Yoser haAdam Benediction", HUCA, 56 (1985), Hebrew section, pp. 9-27, especially p. 24 ff. 


\section{CHAPTER 2}

\section{Literate Woman}

Historical inquiry into rates of literacy is essentially an interdisciplinary one combining anthropology, sociology and statistics; archeology, epigraphy, and art; the study of historical sources of different cultures and periods. Since no individual could possibly achieve profound or even adequate expertise in all these fields, even seemingly simple texts can present difficulties to the most able scholar. The difficulties facing anyone seeking to assess the degree of literacy in antiquity can thus begin to be appreciated. ${ }^{1}$ As complex as the issue is, the study of literacy among women in ancient cultures is an even more vexing question. Besides the aforementioned difficulties, we must deal not only with the status of women in society in general but also with the literary question of determining whether a given text was written by a woman, based on literary features and style. The meager information about women in the ancient world is almost disheartening enough to warrant abandoning the whole project. Nevertheless, following this clarification of the obstacles confronting us, let us now turn to literacy among women in Jewish antiquity. ${ }^{2}$

Two factors combine to determine the degree to which women possessed the skill of writing in antiquity: 1) the prevalence of writing in society as a whole, among men and women; 2) the social position of women in the ancient world and its reflection in women's literacy. We will proceed chronologically: turning first to ancient Mesopotamia (Mari, Sippar) and ancient Egypt, then to the Israelite period; to the Graeco-Roman world and finally to the Jews of the last centuries of the first millennium and the first centuries of the second millennium.

\footnotetext{
1 On writing in antiquity, see A. Demsky and M. Bar-Ilan, "Writing in Ancient Israel and Early Judaism," Compendia Rerum Iudaicarum ad Novum Testamentum, Section II, vol. 1, MIKRA, M.J. Mulder (ed.), (van Gorcum, Assen / Maastricht \& Fortress Press, Philadelphia, 1988), pp. 1-38; A. Demsky, "Literacy," Eric M. Meyers (ed.), The Oxford Encyclopedia of Archaeology in the Near East (Oxford University Press, New York Oxford, 1997), III., pp. 362-368.

2 For a totally different perspective on the issue of literacy among men, see M. Bar-Ilan, "Illiteracy as reflected in the Halakhot concerning the Reading of the Scroll of Esther and the Hallel," Proceedings of the American Academy for Jewish Research, 54 (1987), Hebrew section, pp. 1-12.
} 
Let us begin by recalling that literacy was not all-pervasive in the ancient world, just as not all people were proficient in stone-cutting or wood-carving. Writing was a daily activity, although considered a technical skill to be mastered by professional scribes. ${ }^{3}$ The number of scribes possessing the skill of writing was small, as was the number of other technical professionals such as builders and lathe-turners (farmers are the exception), adopting to the needs of society. The literate apparently belonged to the social elites, due to the link between the art of writing and royal administration.

Moreover, when discussing women's literacy, it must be recalled the profession of scribe was considered masculine - indeed, all ancient literature was masculine. Weaving was the quintessential feminine skill. Women were barred from the art of writing because of their lowly social position, but we must be wary in such observations. Women were not considered inferior in all societies, but merely fulfilled different functions from men. In the traditional world-view, one's status, profession and social relations were predetermined from birth. Exceptions did exist, however, and we will be dealing here precisely with those exceptional literate women.

Let us then examine the historical evidence derived from various sources regarding literacy among women in antiquity.

\section{The ancient world}

Seals belonging to the queens of Mesopotamia have been discovered: the seal-ring (or seal impression) of Nin-tur, wife of Massanfadda, founder of the first Ur dynasty in the third millennium B.C.E.; the sealring of Queen Shulgi-Simati of Ur, 2100-2000 B.C.E.; the seal-ring of Shlurtum, wife of the founder of the Uruk royal dynasty; the seal-ring of Podokhata the Hittite, wife of Khatushilish III in the thirteenth century в.C.E.; and the seal-ring of Taonana, wife of Shupiluliuma. The inscription on this last ring reads: "The great queen, daughter of King of Babylon."

3 On literacy in the ancient world to modern times, see Robert Pattison, On Literacy The Politics of the Word (New York - Oxford, 1982), pp. 221 ff. (includes annotated bibliography on the subject.) The only Hebrew literature on this subject is A. Stahl, "Yediat kro ukhtov ve-ha-ma`avar le-tarbut modernit," Anthology of Translated articles, 7 (The School of Education at the Hebrew University in Jerusalem and the Ministry of Education and Culture, Jerusalem, 1973).

4 The descriptions of the queen's seal-rings are taken from Shoshana Arbeli, Nashim ramot dereg ba-mikra ume oravutan bahÄayim ha-politiyyim ve-ha-hevratiyyim behashva'a lamazui biteudot min ha-mizrah ha-kadum (Ph.D. thesis submitted to the Hebrew University of Jerusalem, 1984), pp. 9-53 (Hebrew); on Queen Shibbatu see Bernard F. Batto, Studies on Women at Mari (Baltimore and London, 1974), pp. $8 \mathrm{ff}$. 
Likewise, we know of letters written by Queen Mother Balti-matim to Zimri-lim, king of Mari, as well as the letters of Shibbatu, wife of Zimri$\mathrm{lim}$, to the king and to other prominent women. We also know of letters addressed to the queen. It is therefore not surprising that Queen Shibbatu possessed several seal-rings. One of these bore the inscription: "Shibbatu daughter of Yarim-lim, wife of Zimri-lim." These seal-rings would seem to indicate that the woman who owned the seal could write. Had the royal letters been written by a scribe, he would have signed his own name, and the queen would not have possessed a personal seal-ring. ${ }^{5}$ The queen's seal-rings corroborate our knowledge that circa 1800 B.C.E., women in Mari served as clerks and secretaries. ${ }^{6}$ More than ten additional woman scribes from Sippar are known to us by name from the same period (1894-1595 B.C.E.); some were daughters of scribes in the Babylonian administration. ${ }^{7}$ Women scribes were rare, but did exist. An Assyrian inscription from a later period has been discovered which reads "Six women scribes in Aramaic". ${ }^{8}$

There were literate women in ancient Egypt as well, though their absolute or relative number cannot be determined. ${ }^{9}$ The ancient Egyptians had a god of writing, Thot, patron of scribes.. Depictions of his consort, Seshet, the writer-goddess (or: goddess of writers) from the early kingdom, (28th century B.C.E.) may be an indication that literate women served in the temple cult. ${ }^{10}$ Women scribes were employed by women in high social and administrative positions, and apparently there were also literate princesses. We know of feminine literature, i.e., love songs written from a woman's perspective. This shows, albeit obliquely and

5 It is commonly accepted that the owner of the seal was a literate person, although I do not know of any conclusive proof of this. In any case, the burden of proof lies upon anyone claiming otherwise.

6 According to J. Botero, editor of S.N. Kramer, From the Tablets of Sumer (The Falcon's Wing Press, Indian Hills, 1956, Hebrew translation: Hahistoriya mathila beSumer, Merhavya, 1960), p. 62.

7 Rivkah Harris, Ancient Sippar: A Demographic Study of an Old-Babylonian City (Istanbul, 1975), pp. $196 \mathrm{ff}$;; 284 ff.; $302 \mathrm{ff}$. In Sippar there was a cloister of aristocratic women employing both male and female scribes. See statistics below.

8 R.P. Dougherty, "Writing upon Parchment and Papyrus Among the Babylonians and the Assyrians," JAOS, 48 (1928), pp. 109-135 (esp. p. 129). For the possibility that some Mesopotamian literary works were written by women, see S. Shifra, "Mesaper o mesaperet: masa al shalosh yezirot atikot," Moznayim, 64/3-4 (1990), pp. 8-10 (Hebrew).

9 An extensive, in-depth discussion of literacy in ancient Egypt, including female literacy, can be found in J. Baines and C.J. Eyre, "Four Notes on Literacy," Goettinger Miszellen, 16 (1983), pp. 65-96 (esp. pp. 81 ff.)

10 See James Henry Breasted, "The Physical Processes of Writing in the Early Orient and their Relation to the Origin of the Alphabet," American Journal of Semitic Languages and Literatures, 32 (1915-6), pp. 230-249, p. 235. 
inconclusively, that besides knowing how to write, women also engaged in creative writing. Egyptian art did not usually depict women engaged in the act of writing, but wall-paintings discovered in five tombs show a woman with a scribe's writing implements under her chair. A seal has also been found engraved with a woman's name. This evidence might provide some insight into the degree of literacy among women in ancient Egypt. ${ }^{11}$

\section{Israelite women in the biblical period}

The Bible, as historical document for the study of the status of women in society in antiquity, is notoriously problematic, for reasons which need not be set out here. The characterization of women in the Bible has led to extensive discussions about the status of women in Biblical literature and the First Temple period. Until then, women were characterized in respect to traits and qualities, not their degree of literacy. ${ }^{12}$ Let us then turn now to biblical sources dealing with women as writers, though these are few. ${ }^{13}$

The first relevant incident is Jezebel's ploy in the affair of Naboth the Jezreelite (I Kings 21:8). Jezebel fabricated a complaint in her efforts to bring about the death of Naboth: "So she wrote letters in Ahab's name and sealed them with his seal, and sent the letters to the elders." 14 That is, Jezebel wrote lies in the name of the king. Jeremiah refers to this practice as well: "Assuredly, for naught has the pen labored, for naught the scribes!" (Jer. 8:8), as does Job: "O that my accuser [would] draw up a true bill!" (Job 31:35), alluding perhaps to a lawsuit similar to the case of Naboth. It is interesting to note that Jezebel did not use her own seal (perhaps she did not have one), as she needed the official royal stamp for her words, and the elders of Jezreel obeyed the command of the

11 Steffen Wenig, The Woman in Egyptian Art (McGraw-Hill, New York, 1969), pl. 103.; Barbara S. Lesko, "Women of Egypt and the Ancient Near East," Renate Bridenthal et al., eds., Becoming Visible, 2nd ed., (Boston, 1987), pp. 41-77 (esp. p. 57); and see especially Betsy M. Bryan, "Evidence for Female Literacy from Theban Tombs of the New Kingdom," Bulletin of the Egyptological Seminar, 6 (1985), pp. 17-32.

12 F. E. Greenspan, “A Typology of Biblical Women," Judaism, 32 (1983), pp. 43-50. A full bibliography can be found in Arbeli's thesis, above, note 4.

13 See also A. Demsky, Literacy in Ancient Israel and Among Its Neighbours in the Biblical Period, (Ph.D. thesis submitted to the Hebrew University of Jerusalem, 1976), Hebrew.

14 Cf. Esther 3:12: "The orders were issued in the name of King Ahasuerus and sealed with the king's signet"; ibid 8:8: "for an edict that has been written in the king's name and sealed with the king's signet may not be revoked." On Jezebel's signet, see Arbeli's thesis, above, note 4, p. 531. 
king, knowing all along that their perjury would bring about Naboth's death.

It is perhaps no coincidence that Jezebel, possessed of the art of writing, was the daughter of the king of Tyre. It seems that she acquired the skill in her father's house, as befitting her status of princess raised in a foreign, non- Israelite culture. The uniqueness of Jezebel's skill is highlighted by the fact that her contemporary, the prophet Elijah, apparently did not write his prophecies in a book. ${ }^{15}$ In Jezebel's day, then, prophets had not yet adopted writing as the medium by which to transmit the divine message, whether they were literate or not. We have, then, a literate woman exploiting the skill of writing for her own purposes, while the prophet remained in the oral mode; later, in the mid 8th century B.C.E. the prophets would embrace the written word as the appropriate means for transmitting God's word to His people.

In later Jewish tradition we find another woman writing in Persia and perhaps we even possess her writings. At the end of the book of Esther (9:29) it is written: "Then Queen Esther daughter of Abihail wrote a second letter of Purim." 16 Again, the queen's literacy accords with the assumption that the acquisition of writing was reserved only for the social elite. Another resemblance between Jezebel and Esther should be noted: Esther, too, was a queen in the court of a foreign king, though Esther had probably acquired the skill of writing in the home of her cousin, Mordecai the scribe, who was exiled from Jerusalem and became second only to the king, enjoying great prominence among the Jews. ${ }^{17}$

15 However, see 2 Chron. 21:12: "A letter from Elijah the prophet came to him which read"; however, this affords no conclusive proof that the prophet Elijah could write, as letter may be merely a technical term, and lemor may refer to an orally transmitted message.

16 The next verse reads "and letters were written, at Mordecai's dictation, to the Jews" (Esther 8:9). However, Esther 9:20 reads: "Mordecai recorded these events. And he sent dispatches to all the Jews." We are dealing here with two parallel literary traditions, which we will not discuss here at length. A textual amendment may be in order: the text should read "and she sent letters to all the Jews." According to one tradition, then, it was Mordecai who wrote and sent the letters, while the parallel tradition has it that Queen Esther wrote and sent the letters herself. It would be interesting to compare Esther to Jezebel in 1 Kings 21:8: "So she wrote letters in Ahab's name, and sealed them with his seal," (the queen herself), whereas we read of Esther: (Esther 8:8) "And you may further write with regard to the Jews as you see fit. Write it in the king's name and seal it with the king's signet" (the queen's scribes).

17 In both cases there was misuse of the king's signet, due to the custom of giving the king's signet to one of the king's courtiers to use. Cf. Ahiqar's title: "scribe of the king of Ashur and Ninveh and bearer of his signet" (precursor of the British title Lord Keeper of the Great Seal. See The Book of Ahiqar: James H. Charlesworth (ed.), The Old Testament Pseudepigrapha (Doubleday \& Company, Garden City, 1983-85, II., pp. 479-507. Ahiqar complains that the same thing happened to him - Nadin, whom he had raised 
The letter's content shows that Esther could write Hebrew, so clearly her literary knowledge was not acquired in the royal harem. ${ }^{18}$

Another woman writer is mentioned among the returning exiles in the time of Ezra: "The sons of Solomon's servants: ...the sons of Hasophereth [lit., the woman scribe]" (Ezra 2:55; Nehemia 7:57; The Vision of Ezra 3, 5:33). This indicates a family whose genealogy included a woman scribe employed in the royal administration under Solomon or his descendants, the kings of Judah. Nothing is known of that woman scribe other than that this important woman was raised in a courtier's family or one employed in the service of the royal administration, where she received an education that qualified her to become a scribe. ${ }^{19}$ Several Bible scholars claim, without any conclusive evidence, that some biblical books were written by women. ${ }^{20}$ This literary question is based, in turn, on the historical question of how widespread female literacy was. Written documents and archeological finds attest the existence of literacy among women in the ancient world, so so it cannot be ruled out that women created an oral literature or even wrote parts of literary works.

betrayed him and wrote letters "in my name and sealed them with my signet."

18 According to rabbinic tradition Esther was a prophetess (b. Megilla 14a) but the sages did not link this to her ability to write, as Jewish tradition was dominated by the masculine authorship of the Book of Esther. Her request to the sages (b. Megilla 7a) again implies parallel literary traditions about Esther's literacy. See Chapter One, above and: Katheryn P. Darr, Far More Precious than Jewels (Westminster/John Knox Press, Louisville, Kentucky, 1991), pp. 164-202.

19 This incident is unique in that it mentions the mother by profession: "sons of the scribe", a matriarchal reference in a patriarchal society. This sort of reference, even if additional instances can be found in biblical geneaology, is nevertheless most rare. See, for instance, Gen. 36:14; Gen. 36:39; 1 Chron. 2:16-17. The appellation "slaves of Solomon" does not seem to refer to actual slaves but rather to senior officials, as in the case of the "servants of the king" seals discussed below. However, some scholars prefer to read "Hasopheret" as a man's name, although it is unknown elsewhere. See: S. Mandelkern, Veteris Testamenti Concordantiae (Shocken, Tel-Aviv, 1967), p. 1488; F. Brown, S.R. Driver and C. A. Briggs, A Hebrew and English Lexicon of the Old Testament (The Clarendon Press, Oxford, 1968), p. 709.

20 On this issue, see S.D. Goitein, Iyyunim bemikra, ${ }^{3}$ (Tel-Aviv, 1967), pp. 248 ff. (Hebrew); English translation as: "Women as Creators of Biblical Genres," Prooftexts, 8 (1988), pp. 1-33. Modern research and experience show that a woman writer may assume a male persona; one cannot determine, solely on the basis of content, whether a man or woman wrote a given composition. See below, Chapter Three, regarding the probability that the Song of Deborah and the first two chapters of the Book of Lamentations were written by women. See: Athalya Brenner and Fokkelien van Dijk-Hemmes, On Gendering Texts: Female and Male Voices in the Hebrew Bible (E.J. Brill, Leiden - New York - Koeln, 1993); Alice Ogden Bellis, Helpmates, Harlots, and Heroes: Women's Stories in the Bible (Westminster/John Knox Press, Louisville, Kentucky, 1994), pp. 29, 193. 
The Bible uses the term "prophetess" for Miriam, Deborah, Hulda, Noadia, and others. ${ }^{21}$ Prophetesses were few compared to the number of men prophets known to us both from the Bible and rabbinic literature. ${ }^{22}$ As the prophets were required by divine commandment to put their prophecies and accounts of royal events down in writing, it is quite possible that prophetesses also took part in this literary activity which ultimately resulted in the creation of the biblical corpus. ${ }^{23}$

Following our examination of literary sources, let us see what evidence may be yielded by the archeological findings of women's seals from the First Temple period. Proof of the scarcity of women scribes lies in the relatively small number of seals belonging to women. Several seals or seal-imprints belonging to women, not necessarily Israelites, from the biblical period are surveyed below in chronological order:

An Aramaic seal from the eighth century B.C.E. is inscribed: "Belonging to Ahat daughter of Nasri",24 and an Ammonite seal of that same period is inscribed: "Belonging to Anamawet servant of Dabalbes." A Phoenician seal of the ninth or eigth century B.C.E. is inscribed "Yizevel" (though this could be a man's name), and another seventh century B.C.E. Phoenician seal reads "Batasham." A Hebrew seal of the eighth or seventh century B.C.E. is inscribed "Belonging to Abigail wife of Asiyahu." 25 Another seal from that same period found in a burial cave near the Sultan's Pool in Jerusalem is inscribed: "Hamiohel daughter of Menahem."26

21 The prophetess Miriam, sister of Aaron (Ex. 15:20), i.e., the sister of a priest and of a levite; Deborah (Judges 4:4), leader of the people; Huldah, wife of "the keeper of the wardrobe" (i.e., a senior official in the kingdom or temple administration) who prophesied about the Scroll of the Teaching found in the times of Josiah (2 Kings 22:14); and the prophetess wife of Isaiah (Isaiah 8:1,3), who was also involved in the writing activity of her husband. There were also false prophetesses: Noadiah (Nehemia 6:14) and her anonymous precursors (Ezekiel 13:17 ff).

22 Cf. the status and function of the prophetesses in Mari in Batto's book (above, note 4), pp. $119 \mathrm{ff}$.

23 A distinction should be made between an oral composition and a written one. A.M. Haberman, "Meshorerot yehudiyot bimei kedem," Miperi ha-et ve-ha-et, (Jerusalem, 1981), pp. $39 \mathrm{ff},($ Hebrew), opens his discussion with Deborah, the poet-prophetess. Her song (Judges 5:1 ff.), however, would seem to exhibit marked features of an oral composition; see below, Chapter Four. The prophetess Deborah mentions male scribes in her song, "such as of Zebulun who holds the marshal's staff" (Judg. 5:14) and not female scribes: it is hence more difficult to view Deborah as a scribe.

24 N. Avigad, "An Early Aramaic Seal," IEJ, 8 (1958), pp. 228-230.

25 A.S. Hartom, "Abigail," Encyclopaiedia Mikrait, 1 (Jerusalem, 1950), columns 12-22 (Hebrew); S. Yeivin, Mehkarim be-toldot yisrael ve-artzo (Tel-Aviv, 1950), pp. 250 ff.; 285 (Hebrew).

26 A discussion of the two Phoenician seals, and the seal of Hamiel, as well as a short discussion about women's seals, appears in Ruth Hesterin and Michal Dayagi-Mendels, 
A seal from the seventh century B.C.E. is inscribed "Belonging to Ahatmelech wife of Yesha," and seals from Eretz-Israel in the same century read "Belonging to Ne'ehevet daughter of Remalyahu," 27 and from Jerusalem reading "Belonging to Menahemet wife of Gadmelech." On an jar from the seventh century B.C.E. there is a seal reading "Belonging to Menahemet wife of Gadmelech."28 Another seal from that century bears the inscription: "Belonging to Yeho'eden daughter of Ariyahu" (the name of mother of king Amatzia), and another reads only "Meshulemet" (the name of wife of King Menashe and mother of King Ammon). ${ }^{29}$ Hebrew seals from the sixth century read: "Adata wife of Pashhur" and "'Amadyahu daughter of Shabanyahu." 30 Similar seals read: "Belonging to Elsegev (daughter of) Elshem'a", "Aliya servant of Hannanel"; "Avihai daughter of Yenahem"; "Belonging to Avihai daughter of 'Aziya" (apparently Ammonites) and "Yehoyishm'a daughter of Shaush-shar-usur," all apparently dated circa the sixth century B.C.E. ${ }^{31}$ True, some of these women were non-Israelites, and a Jewess whose father bears a Babylonian name "Shaush-shar-usur" (circa 540 в.C.E.) tells us that she or her father were born outside the borders of Eretz-Israel.

Three more seals belonging to women are especially noteworthy. A seal found near Lachish, circa the eighth century B.C.E., is inscribed with a crowned sphinx shown with the royal staff and underneath, the word: "Belonging to Hannah." 32 This unusual seal presents the woman as an independent person, not as "daughter of," "wife of" or "handmaiden of"). The decoration and symbols are unequivocal and imply that this seal belonged to a daughter of a king of Judah. The affinity between royal power and the acquisition of literacy and administrative skills is

Hotamot mimei bayit rishon (Israel Museum, Jerusalem, 1988), pp. $24 \mathrm{ff}$ (Hebrew).

27 Yeivin (following Diringer) surmised that Ne'ehevet was the daughter of the owner of the seal "Remalyah ben Neriyahu," showing that a senior official or scribe had a literate daughter, see below.

28 N. Avigad, "A Note on an Impression from a Woman's Seal," IEJ, 37 (1987), pp. 18-19. This is the only case, out of 195, of a woman's seal on a jar (numbering according to: G. Barkay in Eretz-Israel, 23, 1992, p. 127 note 39).

29 N. Avigad, "The Contribution of Hebrew Seals to an Understanding of Israelite Religion and Society", in Patrick D. Miller et al., eds., Ancient Israelite Religion, Essays in Honor of Frank Moore Cross (Fortress, Philadelphia, 1987), pp. 195-209.

30 S. Heltzer and M. Ohana, Masoret ha-shemot ha-ivriyim ha-huz-mikra'iyyim (Haifa, 1978), pp. 28, 29, 31, 34, 39, 40, 45, 57, 62 (Hebrew); See additional bibliography there.

31 A. Reifenberg, Hebrew Seals and Stamps (London, 1950); N. Avigad, "Some Decorated West Semitic Seals," IEJ, 35 (1985), pp. 1-7.

32 J.R. Bartlett, "The Seals of HNH from the Neighbourhood of Tell de-Duweir," PEQ, 109 (1976), pp. 59-61. Prof. A. Demsky called my attention to the possibilitity that this may be a Phoenician seal belonging to a man. 
seen also in the interpretation of another seventh century B.C.E. seal. This seal is engraved with a lyre, and underneath it is written: "Belonging to Ma'adana daughter of the king." Here is the seal of a Jewish princess, but the name of her father, the king, is not known..$^{33} \mathrm{~A}$ seal from the early Second Temple period reads: "Belonging to Shelomit, handmaiden of Elnatan Peha," that is, the seal belonged to Shelomit, servant of Elnatan governor of Judah under the Persian empire. Perhaps "handmaiden" (amah) designates none other than his (second) wife or concubine, but it would seem that here "servant" refers to the category of a clerk employed in the service of the king, as in other seals belonging to royal officials. ${ }^{34} \mathrm{~A}$ synthesis of these various interpretations allows us to conclude that in addition to being the Peha's wife, Shelomit served in the capacity of clerk in the royal administration. The owner of the seal is perhaps Shelomit, daughter of Zerubabel, governor of Judah, descendant of King David. This suggests that the governor married a prominent woman of the royal family perhaps in order to consolidate his rule. ${ }^{35}$

Seals of twenty-three women from the biblical period have been discovered, most if not all of them from the social elite. Literate owners of seals existed not only among Judean, or Israelite women, but also among Ammonite, Aramean and Phoenician women. It is however difficult to ascertain the ethnic origin of these women, though they do teach us something of the degree of literacy among women.

So far, over 600 seals and bullae have been discovered in Eretz-Israel and its environs (some are duplicates belonging to the same scribe) and only twenth-three belong to women. ${ }^{36}$ It follows that the percentage of women who could write was less than four percent of the writing

33 N. Avigad, “The King's Daughter and the Lyre," IEJ, 28 (1978), pp. 146-151. On other seals, bearing the title or family relation "son of the king", see N. Avigad, Bullot ivriyot mimei Yirmiyahu, (Jerusalem, 1986), pp. 52 ff. (Hebrew).

34 We know of "Shem'a servant of Jerobo'am," "Shem'a servant of the king”; “'Asaniyahu servant of the king"; "Yehozarah son of Hilkiyahu servant of Hizkiyahu"; "Shabanyo servant of "Aziyo"; "Avihu servant of 'Aziyo"; "Abadyahu servant of the king"; "Yazinyahu servant of the king"; " "Ashana servant of Ahaz." See Yeivin, above, note 25 on some of these seals; $R$. Hesterin and M. Dayagi-Mendels (aboe, note 26).

351 Chron. 3:19; Haggai 1:1; See N. Avigad, "Bullot ve-hotamot mitokh arkhiyon mamlakhti mimei shivat zion," Kedem, 4 (Jerusalem, 1976), pp. 8-11, 24; E.M. Meyers, "The Shelomith Seal and the Judean Restoration - Some Additional Considerations," Eretz Israel, 18 (1985), pp. 33-38.

36 If we add up the seals mentioned in dozens of articles, we find that over eight hundred seals and bullae have been discovered. From these, however, one must subtract the seals that bear only decoration and those that are indecipherable. If we then subtract the duplicates and the questionable seals, their number shrinks even further. 
population. ${ }^{37}$ But what was the percentage of women writers in the population as a whole?

The skill of writing must be considered first and foremost a masculine occupation, and we must be aware of the vast gulf between the number of literate men and women, even today in certain societies. In addition, the prevailing assumption, frequently inaccurate, has it that the population comprises fifty percent men and fifty percent women in fact, women usually slightly outnumber men. If, at the end of the Second Temple period, literacy in the general population reached about $1.5 \%-4 \%$, then the number of literate women would be about $4 \%$ of this figure. ${ }^{38}$ However, in light of what we have stated above - that there were four women out of one hundred seal-owners, i.e., literate women, and all the rest were men - the result would be that the percentage of literate women in the general population was $0.06 \%-0.16 \%$, which is about $0.12 \%-0.32 \%$ of the female population. In other words: one or at most three women in every thousand could read and write in the First Temple period. ${ }^{39}$ We can understand, then, why women were not shown reading or writing in paintings and reliefs in the Ancient Near East, as the artists considered a woman scribe an anomaly.

Apparently in later periods, too, women scribes were not common either among Jews or in neighboring cultures. Indeed, experts on literacy in the ancient world have long since issued the following dictum: the more literate men there are, the smaller the difference between the number of literate men and women. When literacy among men decreases, the difference between the sexes grows. ${ }^{40}$ In other words, the

37 According to a detailed study of Sippar (above, note 7), 185 names of scribes are known from there, and an additional 13 female scribes. This shows that the ratio of female scribes to male scribes was about 1:6; we must however take into account the special social structure of an autonomous female society unlike anything known to us elsewhere.

38 On the problem of literacy in Antiquity see Baines and Eyre (above, note 9), and see below. The assumption that Egypt was a culture of scribes, inherently different from the Eretz-Israel culture, results in the calculation that the level of literacy in Eretz-Israel was relatively 2-8 times higher than in Egypt (although there is no proof that the literacy rate in Eretz-Israel was very different from that in Egypt). However, one should bear in mind that (hundreds of) hieroglyphics are more complicated to study than some 22 characters.

39 The percentage is so minute that any fluctuation in the "real" figure significantly alters the percentage. For this reason, these percentages must be viewed as no more than a working hypothesis. At the same time it must be noted that the list of the seventy (!) Children of Israel counted going to Egypt (Gen. 46:8-27) mentions two women: Dina, daughter of Jacob, and Serah, daughter of Asher; i.e., about 3\% of the women (there were obviously other women among them whose names are not mentioned and who were not counted).

40 For instance: men $-96 \%$, women $92 \%=$ a ratio of $96: 100$; men $70 \%$, women $20 \%=a$ 
number of literate men in Eretz-Israel in the First Temple period was so low that it is difficult even to estimate, since even the slightest deviation of $0.02 \%-0.04 \%$ would alter our estimate and even double it. In any case, it is evident that there were very few literate women in the ancient world. ${ }^{41}$

\section{Literacy in the Graeco-Roman World}

The picture of female literacy in the Hellenistic world was brighter than in the East. Documents, archeological finds and art clearly show that even prior to the classical Greek period, there were women who could read and write. ${ }^{42}$ The situation varied from one Hellenistic culture to another, but all the evidence underscores the higher percentage of literate Hellenistic women and the lower percentage of literate Jewish and other Near Eastern women. Three observations may explain this discrepancy: 1) Eastern society tended to restrict women to family obligations more than European society; 2) In Hellenistic culture each individual was free to administer his or her own affairs, whereas in monarchic Eastern societies the king controlled everything, including literacy; 3) Greek writing was, from its inception, separate from the priesthood or administration and the attitude towards writing approached our

ratio of $28: 100$; men $20 \%$, women $2 \%$ a ratio of $10: 100$, etc. Accordingly, $4 \%$ of the men were literate, and $0.16 \%$ of the women, a ratio of only $4 / 100$. Incidently, this ratio of literate men and women shows clearly that the level of literacy in society was much lower than ten percent. Scholars have reached this conclusion from a study of the data on the differences in literacy between the sexes. See the tables comparing literacy in different countries, and chronologically in each country. Studies on literacy in the nineteenth century can be found in Carlo M. Cipolla, Literacy and Development in the West (Penguin Books, Middlesex, 1969). For figures on literacy in the twentieth century, see World Illiteracy at Midcentury (UNESCO, 1957), 70, 84, 118, 164. On the status and education of women in the seventeenth to the twentieth centuries see Harvey J. Graff, Literacy in History, An Interdisciplinary Research Bibliography (New York and London, 1981), pp. 356 ff.

41 It should be further noted that a wise woman need not necessarily have been literate (II Sam. 14:1 ff; ibid 20:16). Even the royal lady (Proverbs 31:1) teaching wisdom and morals to her son dealt perhaps in an oral tradition; even if she could read, this does not furnish proof that she could write.

42 Susan Guettel Cole, "Could Greek Women Read and Write?" Helene P. Foley, (ed.), Reflections of Women in Antiquity, (New York - London - Paris, 1981), pp. 219-245; William V. Harris, Ancient Literacy (Cambridge, Mass. - London, 1989), pp. 22-24, 106108; Mary R. Lefkowitz, "Did Ancient Women Write Novels?", Amy-Jill Levine (ed.), "Women Like This": New Perspectives on Jewish Women in the Greco-Roman World (Scholars Press, Atlanta, Georgia, 1991), pp. 199-219; Ross S. Kraemer, "Women's Authorship of Jewish and Christian Literature in the Greco-Roman Period," ibid., pp. 221-242. 
modern understanding of literacy as a skill accessible to all. Even if we assume that literacy among women in Greece was ten- or even twentyfold higher than that of women in Eretz-Israel, they remained perhaps one percent of the general population. In any case, even with allowances for variations of time and place, this figure is relatively quite high, so it is not surprising that we have many depictions of Greek women reading or holding a papyrus scroll or tablet (though not actually writing). 43

As stated above, the prevalence of literacy among Greek and Hellenistic women was not uniform. In Hellenistic Egypt, for instance, we know of literate women, but none served in any official capacity of scribe. ${ }^{44}$ We have proof of literacy among women in the beautiful portrait of a young girl from Pompeii holding two tablets in her left hand and a stylus in her right hand. ${ }^{45}$ Three additional paintings of women are known from Pompeii: one of a woman reading, another of a woman holding a scroll, and the third of a woman holding a ledger in her left hand and a stylus in her right, striking a thoughtful pose. ${ }^{46}$

However, Pompeii does not necessarily provide us with evidence of the extent of literacy among women in antiquity. We must not forget that these sources are wall-paintings in wealthy homes, reflecting perhaps the prevalence of literacy among the rich, not a general trend. 47

We can add a Roman tomb inscription, of the first century B.C.E. or first century C.E., reading: "Pyrrhe, scribe of Rubria Helvia. Publius

43 A.G. Beck, Album of Greek Education (Sydney, 1975). Some of the pictures in this important book are more eloquent than a thousand words. It is no coincidence that the lyre (the biblical harp) is featured along with the scroll in some of these pictures, as befitting the nature of classical Greek education. This is significant for the case of Ma'adna, daughter of the king, mentioned above, note 33.

44 H.C. Youtie, "Hypographeus: The Social Impact of Illiteracy in Graeco-Roman Egypt," Zeitschrift fuer Papyrologie und Epigraphik, 17 (1975), pp. 201-221.

45 For this famous illustration, see: R. Etienne, Pompeii: The Day a City Died (tr. by Caroline Palmer, Thamess and Hudson Ltd. - Harry N. Abrams Inc., London - New York, 1992), p. 89. Compare the use in an earlier period (Jeremiah 17:1; Job 19:24: "With iron stylus and lead") not for incising stone, but for a wax-covered tablet. Another painting shows a woman painter at work.

46 For illustrations see H.L. Pinner, The World of Books in Classical Antiquity (Leiden, 1953).

47 Likewise, it must be noted that a similar custom prevailed among the Israelites in that period, of which we learn from literary sources, not paintings. The majority of scribes in the ancient period were priests (as was demonstrated in the article mentioned above, note 1); the sages held that priests were usually wealthy; most writers, accordingly, belonged to affluent social circles. A detailed study on the women of Pompeii, which however does not address the issue of literacy, is M. D'Avino, The Women of Pompeii (Napoli, no date [1977]). 
Rubrius Optatus (dedicated this) to his wife."48 Presumably the woman was a scribe or secretary to a noblewoman: a woman scribe, if such existed, would be employed by another woman; she did not belong to the official bureaucratic system like the convent in Sippar. We have here one woman scribe mentioned among thousands of inscriptions ${ }^{49}$ We do know of several women in the Hellenistic-Roman world who could write, but compared with male scribes, we will once again find how minuscule was the number of literate women in antiquity. ${ }^{50} \mathrm{We}$ have reached the same conclusions via different methodologies and referring to different cultures: literate women were only a fraction of a percentage of the general population. The small number of literate women - Jews and Gentiles alike - stemmed from the social structure in general, and the exclusion of girls in the education system.

\section{Jewish women in the Hellenistic and Roman period}

In the period of the Mishnah and Talmud in Eretz-Israel under Hellenistic and Roman rule, there are only hints as to the existence of literate women. The rabbis held two fundamentally different views on this point and on the education of girls in general. ${ }^{51}$ Some rabbis believed there was no need for women to study Torah (i.e., to know how to read), whereas others were convinced that studying would benefit them.

These two views are formulated once in the Mishnah, at the beginning of the second century C.E., and once in the Palestinian Talmud, about the end of the third century c.E. Mishnah Sotah 3:4 deals with women who must submit to the ordeal of the bitter water upon suspicion of adultery: "Hence Ben Azzai says: A man ought to give his

48 Mary F. Lefkowitz and Maureen B. Fant, Women in Greece and Rome (SamuelStevens, Toronto and Sarasota, 1977), p. 182.

49 Due to the dearth of information about women writers, we must be wary of making conclusive statements regarding the percentage of female writers in antiquity. In any case, even if we say that over time, five additional tombs of women scribes were lost or destroyed (i.e., five times more than existing tombs), we are still in the modest range of a few hundredths of a percentage point. On another learned woman, Pamphile, a daughter of an author of books, see: Mary F. Lefkowitz and Maureen B. Fant, Women's Life in Greece and Rome ${ }^{2}$ (The Johns Hopkins University Press, Baltimore, 1992), p. 168.

50 Leanne Goodwater, Women in Antiquity: An Annotated Bibliography (Metuchen: NJ, 1975), pp. $35 \mathrm{ff}$.

51 L. Swidler, Women in Judaism: The Status of Women In Formative Judaism (Scarecrow Press, Metuchen: NJ, 1976), pp. 92 ff.; 114. See also D. Boyarin, Carnal Israel: Reading Sex in Talmudic Culture (University of California Press, Berkeley - Los Angeles - Oxford, 1993), pp. 170-181. 
daughter a knowledge of the Law so that if she must drink [the bitter water] she may know that the merit [that she had acquired] will hold her punishment in suspense. R. Eliezer says: if any man gives his daughter a knowledge of the Law it is as though he taught her lechery."

One approach encourages girls to study Torah, as it might provide even partial, temporary alleviation in times of distress; for instance, if a woman is made to submit to the ordeal of drinking the bitter waters, her merit would delay the punishment, since studying the Torah would prolong the woman's life. ${ }^{52}$ The other approach holds that teaching a girl Torah is totally useless, mere frivolity. ${ }^{53}$ Rabbi Eliezer says that the study of Torah is useless and some commentators say that it even causes wantonness in young girls; but a different approach is found in $y$. Sotah 3:4, 19a. There, the following story is told:

A Roman matron asked R. Eleazar (Eliezer): "How is it that, though only one sin was committed in connection with the golden calf, those who died, died by three kinds of execution?" He said to her, "Woman has no wisdom except at the distaff, for it is written, "And all the women who were wise-hearted did spin with their hands"' (Ex. 35:25). Said to him Hyrcanus, his son, "So as not to answer her with a single teaching from the Torah, you have lost out on three hundred kors of tithe per year!" He said to him, "Let the teachings of the Torah be burned but let them not be handed over to women!"

Rabbi Eliezer was consistent. He believed not only that teaching a girl Torah was tantamount to teaching her idleness and frivolity, but also that the object of a woman's education was to acquire skill at the spinning wheel (b. Yoma 66b). He had a severe dictum: "Better that the words of the Torah should burn than be transmitted to women". Rabbi Eliezer's extreme misogynist views are consistent with his generally extreme opinions. He was excommunicated by his colleagues (though there is no evidence of any connection with any specific ruling). In any case, the rabbis diverged in their views of teaching their daughters Torah. The result was simple: since studying Torah was based on reading from a Torah scroll, daughters of hard-liners like Rabbi Eleazer could not read, much less write. The Mishnah quotes the opinion: "He may teach Scripture to his sons and to his daughters" (b. Nedarim 4:3). ${ }^{54}$

52 This idea derives from Deut. 11:19-21: "and teach them to your children... that you and your children may endure," etc. However, in b. Kiddushin $29 \mathrm{~b}$, the rabbis expounded on this verse: "and teach them to your children - your sons and not your daughters."

53 The Mishnah then presents an opposition between tiflut and abstinence, hence the connection between tiflut and sexual relations. However, I could find no basis for this interpretation. The definition of the word tiflut is "nonsense," "frivolity."

54 The parallel to this story is found in b. Yoma 66b, where the questioner is a "wise woman" instead of a matron. The continuation of the conversation is omitted there (and 
This suggests a different historical reality in the households of certain sages, reflecting girls' desire to read and write.

Similar approaches regarding the education of Jewish girls reappear two hundred years later in the opinion ascribed to R. Abbahu of Caesarea and Shimon bar Abba (y. Shabbat 6:1, 7d), claiming that the household of Rabbi Judah Hanassi permitted several things, including "to teach the sons Greek, since they were in need of the authorities." And further: "R. Abbahu in the name of R. Yochanan: A man may teach his daughter Greek, as it is a precious stone to her. Shimon bar Ba heard this and said: Because R. Abbahu wants to teach his daughters Greek, he attributes the saying to R. Yochanan? R. Abbahu heard and said: I swear I heard it from R. Yochanan." 55 In other words, though the study of Greek was permitted only to men of that social class that had ties with the authorities, girls were unconditionally permitted to learn Greek. ${ }^{56}$ Thus the halakha could simultaneously provide for the strict requirements of $R$. Eliezer on the one hand, and for the raising of literate daughters (albeit not in their mother tongue), on the other. The reason given for this was that Greek was considered an ornament for a girl: it added to her attraction and especially enabled her to make a good match. R. Shimon bar Abba was skeptical of the authenticity of the attribution of this tradition to $R$. Yochanan, until R. Abbahu had to swear that he had indeed heard it from his exalted teacher. The approach viewing Greek and not the Torah as a helpful tool for a girl accords with ben Azzai's approach. The other approach opposes the

there are other slight differences between the two accounts). Incidentally, this extreme approach prevails to this very day among segments of the Mea She'arim community in Jerusalem, who teach their daughters the Pentateuch in Yiddish translation only.

55 The textual variants in this mishnah most probably reflect not only a philological argument but also a fundamental controversy over the right of girls to study Torah. Literate women of the biblical period belonged to the royal family. In the talmudic period, the literate woman was apparently the daughter of a scribe, who assisted her father and thus learned the skill. I was able to reconstruct a biography of a woman from the genaeology of some of the Sippar women scribes, and also from the accounts of female scribes in later periods, up until modern times. See above note 49 and chapter one note 27 (The daughter of a Yemenite scribe recounted to me how she assisted her father with proofreading). Another possibility is that a woman would learn to read and write only after she married (and had children), in order to assist her husband in matters of business (or in his work as a scribe), as we learn from Greek culture.

56 The parallel is in y. Peah 1:1, 15c. For a short discussion see M. Aberbach, Ha-hinukh ha-yehudi bitekufat ha-mishnah ve-hatalmud (Rubin Mass, Jerusalem, 1982), p . 215 (Hebrew). The sons of Rabbi Judah Hanassi studied Greek (b. Bava Kama 83a); this indicates that teaching even Greek to girls, in the world of the sages, occured only in the wealthiest families and that of the Nassi. 
study of Greek and views the attribution of the tradition to R. Yochanan as nothing short of deceit.

Just as halakhic opinion was divided regarding the education of girls, historical reality, too, was not uniform. Some girls, though not the majority, could read and write. A telling example of the ban against the education of girls is found in the story in Midrash Lamentations Rabbah $1: 49$, about the son and daughter of Rabbi Zadok, who were taken captive in the course of the Great Rebellion against the Romans. Following their separation, they were reunited but failed to recognize each other. After they started speaking they recognized each other, and the sister said to her brother: "I had a brother and he had a birthmark on his shoulder, and when he would come home from school, I would find the birthmark and kiss him there." Zadok the priest had a son and daughter, and the son would go to school while his sister stayed home. This priest's daughter did not study Torah and was illiterate, in keeping with the view of R. Eliezer.

There are only few instances of literate women in talmudic literature. Discussing the question of reading the Hallel aloud on Sukkot, the rabbis said: "If a slave, a woman or a minor recited [the Hallel] to him he must repeat after them what they say (and let it be a curse to him! (m. Sukkah 3:10). This approach holds for reading the Torah: "And all figure in the number of seven, even a woman, even a minor. They do not [however] bring a woman to read the Scripture in public." (t. Megilla 3:11). The same halakha appears with an added explanation (b. Megilla 23a) that the reason women do not read in public is out of respect. ${ }^{57}$ The sages believed that it was improper for a woman to read aloud in public or even by herself in private. More evidence that Jewish women could read is found in t. Berakhot 2:12: "Zabim and zabot, and menstruating women, and women after childbirth are permitted to read [aloud] from the Torah, the Prophets and the Writings, and to study Mishnah, midrash, halakhot and aggadot. But men who have had a seminal discharge are forbidden [to engage] in all [of the aforementioned activities]."

Women read not only the Torah, but the prophets and Hagiographa too, and we can conclude that some women were knowledgeable in Mishnah and midrash as well. The views of these sages stemmed no doubt from a reality in which in fact women could read Torah. Even if

57 On this halakha, and others in the same format: "all + verb present tense pl. + to...." see M. Bar-Ilan, Polemics between Sages and Priests towards the end of the Second Temple Period, Ph.D. thesis at Bar-Ilan University (Ramat-Gan, 1982), pp. $77 \mathrm{ff}$. (Hebrew). 
girls did study Torah, following the approach of ben Azzai, in practice the community enforced the halakhic view of R. Eliezer, in conjunction with the dictum "both are living words of God."

The only woman known to be literate (though not with any certainty) is Beruria, daughter of $R$. Hanina ben Tradion and wife of the scribe and tanna R. Meir. ${ }^{58}$ The following is a discussion between a "Saducee" and Beruria: "A certain Min [Sadducee] said to Beruria: It is written, 'Sing O barren (woman), thou that didst not bear' (Is. 54:1). Because she did not bear (children) is she to sing? She replied to him: You fool! Look at the end of the verse, where it is written: "For the children of the desolate shall be more than the children of the married wife, saith the Lord" (b. Berakhot 10a). The story demonstrates how an observant Jew outsmarts a heretic, and how a woman outsmarts a man - through verbal virtuosity. In any case, unless one claims that Beruria knew by heart, this verse - which is read between the Consolation Haftora Portions - we can safely claim that Beruria could read. ${ }^{59}$

In addition to the halakhot dealing with reading, there are halakhot showing that women could write. In m. Eduyot 2:3 (b. Gittin 20b), we learn of "...a certain old man who used to lend money to all the people of the village, and write out [the bond of indebtedness] in his own hand, and the others signed it: and when the matter came before the sages they declared it permissible." The Talmud continues: "A woman may write her own bill of divorce and a man may write his own quittance since the bill of divorce has no validity until it is signed." We have here a theoretical deliberation pertinent to our discussion, though we cannot fathom the historical reality behind it. This halakha is repeated in a similar style in $\mathrm{m}$. Gittin 2:5: "A woman may write her own bill of divorce and a man may write his own quittance"; we learn from this that there were women, who, even if they did not actually write out their own bill of divorce, were certainly capable of doing so.

The sages disqualified certain people from serving as scribes and writing Torah scrolls, phylacteries and mezuzot. Surprisingly enough, the list includes idolaters, and an actual case of the sort is mentioned (b. Gittin 45b). A Babylonian sage includes women as being unfit for this kind of writing. ${ }^{60}$ The evidence indicates that some women could write,

58 For more on Beruria see above, Chapter One, and below, Chapter Six. See also Shulamit Tov, Demuyot min HaTalmud (Jerusalem, 1988), pp. 67-76 (Hebrew).

59 The previous passage in the gemara recounts another dispute between Beruria and $R$. Meir, and there it also says "look at the end of the verse." However, there the quote follows the word "in addition" so perhaps it is the result of redaction and does not furnish historical evidence about Beruriah.

60 B. Menahot $42 \mathrm{~b}$. They are not mentioned in Soferim 1:13-14. 
and if they did not write a Torah scroll, they at least wrote documents of lesser religious value, such as bills of divorce.

The sages said: "A woman may not teach the scribes" (m. Kiddushin $4: 13$ ), that is, a woman is forbidden to train youths in the art of being a scribe, like the wife of a scribe assisting her husband to prepare parchment, ink, and perhaps proofreading as well. These halakhot teach us two things: 1) boys were encouraged to learn to write; girls were not. 2) Some women did possess skills of reading or writing to the degree that they could instruct others, but there is no way of assessing their proportion in the general population. ${ }^{61}$

In the talmudic period, as a rule, girls were not integrated in the educational system and did not learn to read, much less to write. However, some women could write and even instruct others in writing, though these were few. In any case, compared to the biblical period there was a slight rise in the number of literate women, based always upon the assumed increase in the number of literate men, perhaps as a result of the inspiration of Hellenistic culture. ${ }^{62}$ Needless to say, the entire talmudic corpus is a masculine work, though perhaps some literary works were penned by women during the Hellenistic-Roman period, but there is no conclusive evidence of this. ${ }^{63}$ We can point to oblique evidence of women's ability to write a legal or religious document, and it is not inconceivable that some women would display independent literary creativity. ${ }^{64}$ We know only of one Jewish woman, not belonging

61 Only one woman in the entire talmudic literature is known to have served in the education system (in Babylonia): "Miriam, teacher of infants" (b. Hagiga 4b). However, we cannot tell what her function was, and there is no evidence that she could read and write (her job caring for children may have required her to read, for instance, when a child brought a note from his parents).

62 See M. Bar-Ilan, 'Illiteracy in the Land of Israel in the First Centuries c.E.', S. Fishbane, S. Schoenfeld and A. Goldschlaeger (eds.), Essays in the Social Scientific Study of Judaism and Jewish Society, II (Ktav, New York 1992), pp. 46-61. Elsewhere, I hope to show that in the time of the Mishnah and Talmud there was a rise in the number of literate males compared to the biblical period. As stated above, the significance of this is that there was also a correlate increase in the number of literate women.

63 The Sybilline Oracles, were written by the Alexandrine prophetesses, as stated clearly in Sybilline 3, 813 ff. (It has been claimed that the books were written by men assuming a female literary persona, an unlikely possibility). It has been claimed that the Epistle to the Hebrews was written by a woman, however, this issue is beyond our present scope.

64 It is difficult to estimate the number of literate women, lacking any adequate scale, so we can refer only to the figures from the biblical period. At the same time, it must be noted that of the 2,500 names known to us from talmudic literature, only 50 are women's names (not necessarily literate men or women). This indicates that two percent of the female population were mentioned in the literary sources (whereas the realistic percentage should have approach or even pass $50 \%$, had it not been for the work's literary 
to the milieu of the sages, whose writings have reached us in some part: Miriam the Alchemist, also called prophetess, who lived in Alexandria in the early third century C.E. or earlier. ${ }^{65}$ This Jewish woman was admired by alchemists for many generations, but it seems that her special occupation and her Hellenistic background, so foreign to the world of the sages, make her an exception: perhaps her status as a woman scribe was also unique among Jewish women in Egypt.66 It must be added that among the early Christians there were literate women, but this exceeds the scope of our current discussion. ${ }^{67}$

\section{The social aspect}

In modern scholarship, the apportionment of literacy in antiquity provides methodologies for examining society's attitudes and for studying the social structure itself. At first, literacy was originally a priestly skill employed in the service of Temple and royalty, and remained the restricted domain of the higher social classes only. Even later, when literacy became more widespread from Sumer to Egypt and throughout the ancient world, the skill of writing was still a masculine one and women were deprived of it.

There is a significant difference between allowing women to acquire the skill of reading and writing and other more markedly "masculine" skills. The control of access to the written word, as to any media of

quality and its reflection of a masculine worldview). On women's names in the Talmud see M. Margaliyot, leheker shemot ve-kinuyyim ba-Talmud (Jerusalem, 1950), pp. 39-42 (Hebrew); N.N. Leiter, Zion lenefesh haya (Jerusalem, 1964), pp. 174-175 (Hebrew). See also below, Chapter Three.

65 R. Patai, "Maria the Jewess - founding mother of Alchemy," AMBIX, 92 (1982), pp. 177-197 (idem., The Jewish Alchemists: A History and Source Book [Princeton University Press, Princeton, New Jersey, 1994], pp. 60-91).

66 In any case, the character of Maria fits the theory about the Syblline writers (above, note 53): she was a literate Jewish prophetess in Egypt, with a Hellenistic education. On another prophetess from the first century C.E., Hannah, see Luke 2:36. Hannah bears a similarity to Judith (Hannah, too, was righteous, from the tribe of Asher, a widow, obedient, and prayed often), but it is not known if either one of them could write. Judith bears a similarity to Esther as well (she prayed for salvation, and she exhibited willingness to have sexual relations with a foreign ruler in order to save her people), but such a typological-literary comparison cannot prove her possession of the skill of writing.

67 On women writers in Origen see Eusebius, Ecclesiastical History, VI, 23 (Harvard University Press, Cambridge - William Heinemann Ltd., London, 1953, [LCL], II, p. 69), and Patricia Wilson-Kastner (et al., eds.), A Lost Tradition: Women Writers of the Early Church (University Press of American, Lanham - New York - London, 1981); see also Mary R. Lefkowitz and Ross S. Kraemer (above, note 42). 
information, is a tool wielded by the ruling power, whether men, in one context, or priests and kings, in another. Such means of control guarantee power over the social minority, though in sheer numbers they might be the majority. Women have always been dependent on men to provide food and shelter in times of peace and war; the invention of writing extended this dependence to the field of information, and women were denied any control or influence in that world. Their ignorance stemming from lack of education was interpreted as a lack of understanding, and led men to regard women with derision. By denying their daughters access to literacy, men continued to perpetuate the dependence of women on their husbands and of daughters on their fathers.

Men did not bother to enlighten women in their ignorance. Had women been able to read and write, they would have discovered that there are unfaithful men in the world, or that some women are smarter than men. But as long as women were kept illiterate, they were bound by the masculine concepts of female inferiority, which men equated with physical inferiority and projected onto the intellectual sphere. Traditional society safeguarded its tradition, among other means, by forbidding women to read so that they would know nothing of the world that was not mediated by men.

A man need not have been a misogynist in order to deny his daughter access to reading and writing. Women could not read just as men could not spin. Ancient societies observed a strict division of labor and skills between the sexes. The immediate significance of sending one's daughter to learn to read was forgoing a helping hand at home. The father was not alone in denying his daughter the possiblity of schooling; her mother, too, preferred that her daughter remain by her side and assist in cooking, sewing and other female tasks. It is thus clear that we cannot attribute denial of knowledge from women to men alone, since women bear a certain degree of responsibility.

The economic factor meant that women who could write came from wealthy families, where the daughter's studies in school would not adversely affect the houshold management or the quality of life. However, it is difficult to provide a satisfactory explanation for the fact that among the culture-loving Greeks of the Hellenistic world there were more literate women than in contemporary Jewish society. Social circumstances that remain obscure to the scholar apparently underlie the attitude towards women's education. 


\section{Conclusion}

Cultural differences notwithstanding, the percentage of literate women in antiquity was in general much lower than that of men. Only a small percentage of the population was literate; the degree of literacy among women is measured in hundredths of a percentage. This is in keeping with the position of women in ancient society, and the clear division between masculine and feminine skills, though the influence of the social factor on women's literacy varied in different societies. ${ }^{6}$ It seems that only after the decline of the Roman empire, the start of the Middle Ages, and the encounter between Judaism and Islam, was there some improvement in women's education and literacy (this period merits an independent study based on sources of a different kind). ${ }^{69}$

68 On the social status of Jewish women in the time of the Mishnah and Talmud see Leonie J. Archer, "The Role of Women in the Religion, Ritual and Cult of Graeco-Roman Palestine," Averil Cameron and Amelie Kuhrt (eds.), Images of Women in Antiquity (London and Canberra, 1983), pp. 273-287. The permission granted to women to fulfill various commandments is treated in Polemics between Sages and Priests (above, note 57), pp. 266-7 (with additional references).

69 On wise women and women writers (scribes and authors) in a later period, see S. Ashkenazy, Nashim Lamdaniyyot (Tevuna, Tel-Aviv, 1942); A.M. Haberman, Anshei sefer ve-anshei ma'ase, (Jerusalem, 1974), pp. 362 ff. (Hebrew); A.M. Haberman, Perakim be-toldot ha-madpisim ha-ioriyyim ve-inyanei sefarim (Jerusalem, 1988), pp. $153 \mathrm{ff}$. (Hebrew). On the halakhic aspect see G. Felder, Siddur yesodei yeshurun, 1, (Jerusalem, 1981), pp. 563-564 (Hebrew) See also E. Bashan, "Ha-temurot bema'amada ha-hevrati ve-ha-haskalati shel ha-isha ha-yehudiya bamizrah hatikhon," Mishpahot bet Yisrael - hamishpaha batefisa ha-lyehudit (Publication of the Conference for Jewish Philosophy, 18, Jerusalem, 1976), pp. 177-187 (Hebrew). 


\section{The Keening Women}

In antiquity it was customary to mourn by keening and reciting laments at the funeral and burial. Keening heightened the sense of loss, intensified the sorrow of the individual and the community, and triggered a flood of tears on the part of all the mourners. The custom prevailed among many ancient peoples, including the Israelites, who had professional women keeners as well as men. This chapter will examine the role of women in these ceremonies, analyze feminine laments, and draw conclusions regarding women's social position as reflected in funerary customs.

\section{Biblical literature}

The biblical lament has been thoroughly studied, though the role of keening women in the biblical and post-biblical periods has still to be elucidated. ${ }^{1}$ The female keeners were frequently overshadowed by the men. In Gen. 2:8-10, for instance, following the death of Jacob, we read: “....all of Joseph's household, his brothers, and his father's household... they held there a very great and solemn lamentation" (Gen. 50:8-10), making no reference whatsoever to women. ${ }^{2}$ Though not always acknowledging the keening women, the biblical accounts do make frequent mention of the wailing and elegies of mourning women.

The participation of women in public mourning ceremonies honoring a prominent figure is mentioned explicitly (2 Chron. 35:25): "Jeremiah composed laments for Josiah which all the singers, male and female, recited in their laments for Josiah, as is done to this day; they became customary in Israel and were incorporated into the laments."

We learn, then, that at the close of the seventh century B.c.E., women participated in the mourning rites for King Josiah after his death on the battlefield. Jeremiah as chief mourner led the others, and the men and

1 Y.H. Tigai, "Kina, kinot", Encyclopaedia Mikrait (Jerusalem 1971), col. 125-144 (Hebrew, henceforth: Tigai). No other article in this biblical encyclopedia draws so heavily, and rightly so, on evidence from the post-biblical period.

2 "And the Israelites bewailed Moses in the steppes of Moab for thirty days" (Deut. 34:8). Though the keeners are not necessarily the wailers, the significance lies in that "the women of Israel" are included in "the Israelites" and have no separate identity. 
women singers responded and recited his words after him; later, the lament was put in writing. ${ }^{3}$ However, it is difficult to adduce anything from the information about these female singers as to mourning customs among the common Israelites, since these women may have been court singers of the noble class, and their presence may not be characteristic of funerary customs of the lower social classes. ${ }^{4}$

We can, however, learn from Jeremiah's lament over King Josiah about the role of women in singing dirges. After prophesying to the people that God would "scatter them among nations" and "dispatch the sword after them," Jeremiah continues: "...Summon the dirge-singers, let them come; Send for the skilled women, let them come. Let them quickly start a wailing for us, that our eyes may run with tears, our pupils flow with water. For the sound of wailing is heard from Zion: How we are despoiled! How greatly we are shamed! Ah, we must leave our land, Abandon our dwellings! Hear, $\mathrm{O}$ women, the word of the Lord. Let your ears receive the word of His mouth, and teach your daughters wailing, and one another lamentation" (Jer. 9:16-20).

Jeremiah's summons to the dirge-singers, though referring to public and national mourning, would seem to reflect the custom of women keening at private mourning ceremonies as well. Jeremiah exhorts the women to wail and keen over the destruction of the nation as they were accustomed to do for individuals. From the comparison between keeners and wise women it becomes apparent that wisdom refers here to skill and expertise in keening and reciting dirges, and in leading the chorus of women. ${ }^{5}$ In Het the professional keener was called the "wise

3 For additional examples of simultaneous written and oral processes, see M. Bar-Ilan, "Thus they shall link My name with the people of Israel (Num. 6:27)," HUCA, 60 (1989), Hebrew section, pp. 19-31.

4 Other royal singers are mentioned in Ecclesiastes 2:8: "I further amassed silver and gold and treasures of kings and provinces; and I got myself male and female singers, as well as the luxuries of commoners-coffers and coffers of them" (Ecc. 2:8). The words of Barzillai the Gileadite to David reflect the same spirit: "Can I still listen to the singing of men and women?" (2 Sam 19:36), and this does not indicate low social standing, since it is said of him previously: "He had provided the king with food during his stay at Mahanaim, for he was a very wealthy man" (2 Sam 19:33). A separate issue is that of the standing of the male and female singers returning from the Babylonian exile with Ezra. See Ezra 2:65; Nehemia 7:67. Cf. also the opinion offered by R. Meir in Pirkei de R. Eliezer 17 (ed. R. David Luria, par. 612, 31b), according to which the male singers were the Levites, and the "female singers were their wives." See also, regarding the possibility that portions of the Song of Songs were composed by these singers: Athalya Brenner, The Israelite Woman (JSOT Press, Sheffield 1985), pp. 46 ff.

5 Apparently the only opportunity allowing a woman to exhibit her wisdom was when she keened at someone's death, and the assembled congregation could admire her powers of expression, her use of imagery, etc. Perhaps even the other wise women in the Bible, 
woman," 6 and it seems that the appellation stemmed from the perception of keeners as wise women, acknowledged by men too. ${ }^{7}$ This is attested by the dirge sung by Deborah over the mother of Sisera wailing at the window, mourning her son. Deborah sings thus: "The wisest of her ladies give answer; She, too, replies to herself." (Judg. 5:29). That is, the wise, dirge-chanting women were the royal keeners, wailing along with the mother of Sisera, like the keeners mentioned in our example. The keeners chant aloud, and the mourning mother responds and repeats their words aloud after them. ${ }^{8}$

Whatever the precise meaning of "wise women" may be, Jeremiah's words tell of women who acted independently of men and whose function was to keen on occasions of national mourning; they would probably serve as professional mourners at private funerals as well. These women achieved such proficiency that their services were required on occasions of state. The keening women transmitted their dirges to their daughters, just as men would teach their sons the Oral Law (Deut. 6:7) and women would mourn together "each woman with her companions". The purpose of keening was to intensify the sorrow, to induce a renewed flow of tears. That this art was perfected by women is evident from Jeremiah's dependence on the wailing of women, rather than of men. ${ }^{9}$

the wise woman of Tekoa (2 Sam. 14:2) and the wise woman of Abel beth-maacha (2 Sam $20 ; 15)$, two women with extraordinary and original powers of expression, were also keeners. See below and cf. Brenner, above, note 4, pp. 33 ff. and Chapter One, above.

6 Tigai (column 137) remarks upon "a kind of witch-priestess."

7 Cf. "And all the skilled women spun with their own hands" (Ex. 35:25). It is not their intelligence that is stressed but their artistic talent (as in Ex. 31:6). Conversely, the harsh comment of R. Eliezer, "A woman finds wisdom only at her spinning-wheel" (b. Yoma 66a) blurs the line between artistic talent and wisdom.

8 For the meaning of the verb ע-נ-1 in the Bible in this denotation of raising one's voice, see R. Weiss, Mishut ba-mikra (Jerusalem, 1976), p. 86 (Hebrew). W.P. Albright was of the opinion that the meaning of ותיבב (the JPS edition notes that the Hebrew meaning is unclear) referring to the mother of Sisera was a song of triumph. However, the parallelism between the lament and the song of triumph shows that the reference is to a wail of grief (in place of the cry of victory). Albright's remarks are in N. Avigad, "Seals and Sealings", IEJ, 14 (1964), pp. 190-194. In light of these remarks, it would seem that שרותיה (Judges 5:29) should be read with the letter shin, not sin, to mean singers or keeners, not "the wisest of her ladies."

9 Cf also Jer. 7:29: "Shear your locks and cast them away, take up a lament on the heights." The prophet, after announcing that he will pray for the people, requests the keening woman to lament, after she has carried out the dramatic act of shaving her head as a sign of mourning. Perhaps the prophet's call, "My poor people, put on sackcloth and strew dust on yourselves! Mourn, as for an only child, wail bitterly," (Jer. 6:26) was, in fact, a call to the keening women and not merely a colorful expression. 
The origin of the institution of keening women and the question as to why women in particular, though not exclusively, specialized in elegies and mourning is a difficult one. We know of similar keening women in the Ancient Near East and in Greece. ${ }^{10}$ At the same time, it seems that the Israelite tradition attributed the origin of the custom to the daughter of Jephthah. Jephthah had set off for battle against the Ammonites, having made a vow that if he vanquished his enemy he would sacrifice the first of his household to come out to welcome him (Judges 11:31). Returning home victorious, he was greeted by his only daughter dancing and playing tambourines. Jephthah could not renege on his vow. Jephthah's daughter then says to her father:

"Let this be done to me: Let me be for two months, and I will go with my companions and lament upon the hills and then bewail my maidenhood." "Go," he replied. He let her go for two months, and she and her companions went and bewailed her maidenhood upon the hills. After two months time, she returned to he father, and he did to her as he had vowed. She had never known a man. So it became a custom in Israel for the maidens of Israel to go every year, for four days in the year, and chant dirges for the daughter of Jephthah the Gileadite Judges 11:37-40).

The author of Judges believed that the custom of prescribing that women engage in keening by themselves was of greater antiquity than the monarchy and dated from the time of the judges. The passage is difficult and refers to a dirge for one woman, a virgin, in some kind of closed female ceremony that excluded men, practiced once a year for four days. At the same time, those commentators who believed that the story of the daughter of Jephthah was designed to furnish an explanation of the origin of the institution of keening would seem to be correct, and that in the ancient world, women keeners mourned over women as well as over men. They would first retell the story of the death of Jephthah's daughter, how her joy turned into bitter grief. ${ }^{11}$ The keeners would begin by saying that there was nothing sadder than the death of Jephthah's only daughter, a virgin plucked from the land of the living through no fault of her own. Only later would the women go on to tell of the particular woman who had recently died, whom they had been summoned to mourn. 12

10 Tigai, column $133 \mathrm{ff}$.

11 This opposition between past glory and present disaster, dramatized in the figure of the daughter of Jephthah, finds its apt expression in the lament of Eliphas (Elihu) over Job in the pseudoepigraphic Testament of Job. See James H. Charlesworth, (ed.), The Old Testament Pseudepigrapha (Doubleday \& Company, Garden City, 1983-85), I. pp. 31-32. See below for more about the laments in that book. For the biblical precedents of this phenomenon in laments, see Tigai, column 126.

12 This interpretation of the story of the daughter of Jephthah derives from compara- 
The custom of women gathering to mourn and bewail the death of a young woman is echoed also in the dirge chanted by David over Saul and Jonathan: "Daughters of Israel, Weep over Saul, who clothed you in crimson and finery, who decked your robes with jewels of gold" (2 Sam. 1:24). The daughters of Israel were summoned by the chief keener to participate in dirges over the king and his son who were slain in battle. ${ }^{13}$ It should be noted that women - the Philistine women - are referred to here not only as keeners but as conquerers too: "Tell it not in Gath, do not proclaim it in the streets of Ashkelon, lest the daughters of the Philistine rejoice, lest the daughters of the uncircumcised exult" (20). The author is aware here of the opposition between the custom of the Israelite women to mourn and keen over the downfall of their men and the custom of the Philistine women to exult over and celebrate the downfall of their enemies. Both practices demonstrate how women participated in occasions of national joy and sorrow. ${ }^{14}$

This dialectic between sorrow and joy, two emotional opposites affording opportunities for outbursts of extreme sentimentality, can be seen in the victorious exultation of the women following David's triumph over Goliath:

The women of all the towns of Israel came out singing and dancing to greet King Saul with timbrels, shouting, and sistrums. The women sang as they danced, and they chanted: Saul has slain his thousands; David, his tens of thousands! Saul was much distressed.... For he said: "To David they have given tens of thousands, and to me they have given thousands" (1 Sam. 18:6).

These women celebrated a national triumph by singing and chanting, accompanying their songs with musical instruments. ${ }^{15}$ The triumphant

tive research, which seems more appropriate, despite its shortcomings, than the approach that ostensibly adheres to the simple meaning of the text, according to which the women of Israel would mourn, once a year, over the death of a woman who had died hundreds of years before, despite the fact that it is unknown if she executed any brave deed to rescue the people of Israel. For more about the daughter of Jephthah see below, the discussion of apocryphal sources. Cf. also (though without reference to wailing): Phyllis Trible, Texts of Terror (Fortress Press, Philadelphia, 1984), pp. 93-116.

13 Jonathan's lament may be compared to the lament of the daughter of Jephthah. Both are the child of the ruler (king/judge) and we might say that their father knowingly sends them to their death. Both are first-born, beloved and unmarried. Both, then, can serve as models for women keening over the death of a boy or girl who die as a result of their fathers' sins. See 2 Sam. 12:14; b. Shabbat 32b (the sources differ only in their opinion of the essence of the sin).

14 This parallelism/opposition in David's lament is similar to that in the Song of Deborah. Deborah sang a woman's song of triumph and her song of triumph seems the reverse of David's lament. For further comments on these songs see Chapter Four below, on women praying.

15 Musical instruments would accompany the songs of joy and triumph, and women 
hymn was a spectacle including not only singing, but also dancing and giving thanks to God. ${ }^{16}$ The text makes it clear that King Saul, perceiving the behavior of the women, realized that they gave voice to "the word of the people," and that is what disturbed him so. In any case, it should be noted that this congregation of women from all the cities of Israel resembles nothing so much as the gathering of women mourning the daughter of Jephthah. The singers of joyful hymns and the keeners of dirges, demonstrate the independence of women acting without husband or family, gathering to sing and chant on special occasions of triumph or mourning. ${ }^{17}$ It may be concluded that the singers of triumphal hymns and elegies were also the wise women and prophetesses. In times of national disaster they would keen, and in times of national triumph they sang songs of bravery and praise. On a daily basis they would dispense their wisdom to people coming to consult them, or serve as professional mourners at local funeral processions.

Women's prominence as keeners can be seen further from Ezekial's report of his vision. The prophet tells how the hand of God plucked him from Babylon, deposited him in Jerusalem and showed him the blasphemous acts that were being committed in the temple. He recounts thus: "Next He brought me to the north gate of the entrance of the house of the Lord; and there sat the women bewailing Tammuz"

participated in the playing of musical instruments: "First come singers, then musicians, amidst maidens playing timbrels" (Ps. 68:26). The parallelism between songs of triumph and the laments demonstrates that the laments, too, were accompanied by musical instruments, as shown by Ps. 137:2 and the talmudic sources. See: Gen. 31:27; Ex. 15:20; I Kings 10:12 (2 Chron. 9:11); 1 Chron. 13:8; 1 Chron. 25:6; 2 Chron. 29:27. Cf. also to "play the harlot" (Is. 23:17) and "bawdy songs" (Ez. 33:32), songs that were accompanied by the playing of musical instruments.

16 Perhaps the mourners accompanying the deceased conducted dances of mourning along the lines of the dances of triumph (cf. the dances of women in the Middle Ages before they were burnt at the stake as told by S. Ashkenazi, Neshei yisrael begevuratan (Tel-Aviv, 1990), pp. 23-26 (Hebrew). For the religious significance of the ancient triumphal dances and at funerals see W.O.E. Oesterley, The Sacred Dance (Cambridge University Press, Cambridge, 1923), pp. $159 \mathrm{ff} ; 194 \mathrm{ff}$. In the Jewish tradition dances of mourning are never mentioned explicitly. However, in the Peshita, the Syriac translation of the Bible, the verb $ד$, to mourn, is translated "dance." For example, when Abraham mourns Sara (the sole biblical incidence of mourning over a woman), Gen. 23:2 "Abraham proceeded to mourn for Sarah and to bewail her," (translated into Aramaic as "to dance for Sarah and to bewail her"; and Gen 50:10: "they held there a very great and solemn lamentation," translated in the Aramaic as "they danced there a great dance." That is, mourning was identified with dancing, like the tradition in the book of Judith that connects mourning with clapping hands and stamping feet (see below).

17 Cf. Judith's paean of triumph (Judith 15:12-16:1); women came to hear it from all over the land of Israel, then danced and sang a song of triumph with the accompaniment by drums and musical instruments. 
(Ezekiel 8:14). In the temple, women used to keen over the death of the Canaanite god Tammuz. ${ }^{18}$ Apparently professional keeners mourned not only flesh-and-blood deceased or upon occasions of national disaster, but also over the death of gods. This demonstrates that women were fully integrated in the temple cult in Jerusalem, until the devotees of Jahweh forced them out. ${ }^{19}$

Following the above discussion of women's elevated social and religious position on occasions of national triumph and disaster, we will now examine the feminine aspect of the Book of Lamentations. S.D. Goitein first suggested that the Book of Lamentations was written at least in part by women. ${ }^{20} \mathrm{He}$ raised this hypothesis in the context of feminine literary creativity in general, and as writers of elegies in particular. In truth, Goiteins's suggestion is inconclusive: he claimed that Jerusalem is described in feminine figurative language in Lamentations 1, 2 and 4: Jerusalem is addressed as a mother or as a virgin, and the city is described as a friendless, abandoned widow, the Daughter of Zion denuded of her glory, exiled and shamed. Goitein added that these chapters possess "a feminine quality and speak much of women: mothers with infants, virgins, abandoned women, etc." However, an examination of the figurative language used by the prophets, or biblical figurative language as a whole, will not confirm this view. A man could equally have employed those same tropes. The prophets habitually compared Israel to a woman, whether to a prostitute, a barren women, etc. ${ }^{21}$ Feminine imagery, then, is no proof of the female origins of a literary work. However, perhaps Goitein's theory can be supported inasmuch as it claims that part of the Book of Lamentations might be attributed to women - more specifically, to keening women. To do so, certain linguistic findings which for some reason were unknown to Goitein will be drawn upon. Two approaches can be advanced to demonstrate that the first two chapters of Lamentations were written by women. The first employs linguistic evidence, and the second compares the first two chapters with Lamentations 3. Lamentations 1:11 reads:

18 Tigai, column 133 ff. Cf. also E.E. Halevi, Arkhei ha-aggadah ve-ha-halakha, II, (TelAviv, 1980), p. 141 (Hebrew).

19 Another example of forcing women out of the temple area is seen in the ban against prostitutes bringing their earnings into the temple. See Chapter Six, below, on prostitutes.

20 S.D. Goitein, Iyyunim bamikra, ${ }^{3}$ (Tel-Aviv, 1967), pp. 273-277 (Hebrew). Goitein refers to the feminine composition of the lament about the destruction of the Sumerian city of Ur by "the woman"- the goddess Ningal. See also above chapter two note 20 and: Athalya Brenner and Fokkelien van Dijk-Hemmes, On Gendering Texts: Female and Male Voices in the Hebrew Bible (E.J. Brill, Leiden - New York - Koeln, 1993), pp. 83-90.

21 See R. Patai, Adam va-adama, II, (Jerusalem, 1943), pp. 98-102 (Hebrew). 
"See, O Lord, and behold, how abject (or: What a glutton) I have become" in the feminine form, indicating that the speaker is a woman. It continues: "He hurled me backward; He left me forlorn, in constant misery" (1:13), again using the feminine gender. We have here not only the metaphor of the Daughter of Zion as a widow, which appears at the start of the dirge (and can be interpreted as figurative language "Bitterly she weeps in the night, Her cheek wet with tears"), but also the keener envisioning herself as the entire Jewish people, an identification that requires the feminine gender that is natural to her personal identity. Thus in verse 16 as well: "For these things do I weep," or "When they heard how I was sighing" (21). The use of the feminine gender, unusual in prophetic literature or other dirges, would indicate that a woman wrote the dirge, a woman keener bewailing the calamity of the destruction of Jerusalem. She was probably one of the best professional keeners, that is, her expertise was acquired by mourning over the death of men and women alike. For the public occasion at which this particular dirge was chanted, she adapted the familiar ideas and words of mourning over individuals to fit the occasion of national catastrophe. The dirge was thereafter put into writing (perhaps along with other dirges), as were the hymns of triumphs and prophecies of doom. ${ }^{22}$

The other example of female writing is Lamentations 2, where the use of the female gender is repeated, though in the second person, not the first person: "Shed tears like a torrent day and night! Give yourself no respite, your eyes no rest. Arise, cry out in the night. At the beginning of the watches, pour out your heart like water in the presence of the Lord! Lift up your hands to Him for the life of your infants" (2:1819).

Here, too, it would be wrong to see this as a literary image of Jerusalem or of the people of Israel, since women are asked to do something practical and realistic: to shed tears and wring their hands, in reality not

22 The best example is the song of Moses. Deut. 31:19 has: "Therefore, write down this poem and teach it to the people of Israel; put it in their mouths". However, if we can make a slight textual amendment in 2 Sam. 1:18, we will obtain another, better example. David's lament opens with the difficult phrase: "He ordered the Judites to be taught [the Song of the] Bow. It is recorded in the Book of Jashar." N.H. Tur-Sinai (Mishlei Shlomo [Jerusalem 1947], p. 75 [Hebrew], following Perls, suggested reading "bow" nep as the acronym of "the lament of Saul." However, it seems more likely that we have here an instance of the combination and merging together of the letters This phenomenon is known in biblical and post-biblical literature, (cf. for instance 2 Chron. 14:9, where עפונה should read). Hence, the verse in 2 Sam. should read קינות (2) instead of pשr, yielding the phrase: "to teach the Judites laments written in the book of Yashar (or: Song)." This would mean that the lament was performed orally, and at the same time written down as recounted in 2 Chron. 35:25. 
as metaphor. We have here a keening woman who approached her keening colleagues and urged them to shed tears and raise their hands to God, acts which would render the people's anguish immediate and dramatic. It now becomes apparent that the feminine atmosphere that we referred to above is not a mere literary trope, and the description "Bitterly she weeps in the night" (Lamentations 1:2) should be understood correctly as the description of the actual keening woman mourning "over the ruin of (the daughter of) my poor people" (1:11). The weeping woman of 2:11 is one of many, bewailing her own loved ones along with the national disaster of the destruction of Jerusalem.

Chapters 1-2 of Lamentations are written in the form of an alphabetical acrostic, so it should not be claimed that they are a co-production of two different writers, whether men or women. It is likely that these two chapters were written by women, the keening women mentioned above. There is another piece of evidence to support this claim, this time of a negative nature. Lamentations 3 opens thus: "I am the man who has known affliction" (3:1). What is meant by this pronouncement? The only logical assumption is that the two previous chapters were composed by women, and now it is the male voice speaking. ${ }^{23}$ The keener emphasizes his masculinity by repeating the word "man" (gever) several times: "It is good for a man, when young, to bear a yoke" (3:27), emphasizing that it is now a man mourning, not a woman. It continues: "To deny a man his rights" (3:35), or "Of what shall a living man complain?" (3:39), all of which disclose the speaker's sexual identity: that it is a man speaking. The first two chapters, by contrast, would have been written by women.

The choice of pronouns of male or female gender is not arbitrary, as can be seen throughout the dirge. In Lamentations 4:17 ff. many nouns and verbs appear in the plural form: our eyes, our steps, our days, etc. Likewise, in Lamentations 5 we find: our disgrace, our heritage, our homes. etc. Earlier, the dirges were designated as chanted either by a woman or by a man, now, in chapters $4-5$, they are sung by the chorus, either all-male or all-female or perhaps a mixed assembly. ${ }^{24}$

23 Compare to the opposite practice in a Sumerian lament in which the keening woman says: "I am the woman"; the feminine nature of that lament is well in evidence. See Y. Klein, Lamentations, Encyclopaedia Olam Hatanach: the Books of Song of Songs, Ruth, Lamentations (Jerusalem - Ramat-Gan, 1977), p. 113 (Hebrew).

24 It should also be noted that the identity of the authors is hinted at in the alphabetic acrostic of the verses: aleph - almana (widow), beth - bat Zion: daughter of Zion, gimmel - hagever: the man, dalet - benei Zion: sons of Zion, heh - yetomim vealmanot, orphans and widows. Scholars have remarked the differences and similarities in these chapters. Here we are dealing only with the gender of the performers, and this 
Scholars of biblical dirges have already pointed out that they were chanted at times in antiphonic style, by several performers, one chanting and the other responding. Perhaps this is what is alluded to in Zechariah 12:10-14:

And they shall lament to me about those who are slain, wailing over them as over a favorite son, and showing bitter grief as over a first-born. At that day, the wailing in Jerusalem shall be as great as the wailing in Hadad-rimmon in the plain of Megiddon. The land shall wail, each family by itself: The family of the House of David by themselves, and the womenfolk by themselves.

The prophet describes the contemporary mourning customs of the end of the fifth century B.c.E. Families would mourn, men and women separately: the men would chant first, then the women would repeat the dirge, after the manner described in the song of the crossing of the Red Sea, where the women repeated the triumphal hymn after the men. The format of a chief mourner keening and the other responding, might also be hinted at in the description of the dirge over Josiah in 2 Chron. 35:25: "Jeremiah composed laments for Josiah which all the singers, male and female, recited in their laments." This must have also been the form of the dirge of Sisera's mother described in the song of Deborah: "The wisest of her ladies give answer, she, too, replies to herself" (Judges 5:29). This would be the correct interpretation of the dirge of David for Abner in 2 Sam. 3:32-34: "The king wept aloud at Abner's grave, and all the troops wept." First the chief mourner chanted, then all the rest responded after him. ${ }^{25}$ If these numerous examples do not suffice, we find the antiphonic form of song mentioned explicity in Mishnah Mo'ed Katan 3:9: "What is a lamentation? When all sing together. And a wailing? When one begins by herself and all respond after her," so that laments were sung by male singers and then women repeated after them, or, one of the women would sing the dirge, and the other women would respond.

Traces of the ancient customs of mourning and keening, then, are revealed in the literary structure of the Book of Lamentations. Chapters 1-2 were chanted by professional keening women and the other women responded after them, and then the men responded; the dirge of chapter 3 was chanted by a man, and then the other men joined in and perhaps the women as well. Chapters 4-5 were performed by a combination of

discussion might be of assistance in understanding the sources and means of composition of this book. For more on the study of Lamentations see Osnat Zinger, Iyyunim be-tehinot ha-leumiyot ha-mikraiyot al hurban ha-aretz ve-ha-mikdash: Is. 63:7-64:11; Ps, 74:6-79; Lamentations 5 ( M.A. thesis at Tel-Aviv University, Tel-Aviv 1987, Hebrew).

25 This was how Josephus understood it in Antiquorum Judaorum 7,1,6. 
male or female mourners. ${ }^{26}$ We learn, in any event, that at least two biblical chapters were composed by women. ${ }^{27}$

Now that the participation of women upon occasions of national sorrow and joy in the biblical period has been clarified, we turn to later sources. We will first look at the apocryphal writings.

\section{Pseudepigrapha}

The apocrypha preserves dirges and fragments of texts of mourning of great interest. Pseudo-Philo's Biblical Antiquities will be examined first. ${ }^{28}$ This book was composed about the first century C.E. and preserves some traditions that are unknown to us from other sources; two dirges about women merit our attention.

Following the death of Deborah, we read:

And the people mourned for her seventy days, and while they were mourning for her, they said these words as a lamentation. "Behold there has perished a mother from Israel, and the holy one who exercised leadership in the house of Jacob.

She firmed up the fence about her generation, and her generation will grieve over her (Pseudo-Philo, Biblical Antiquities 3:6).

This passage opens with the information that the mourning period over Deborah is identical to the seventy-day mourning period over the patriarch Jacob (Gen. 50:3); the author thereby asserts that a prominent Israelite woman would meet with the same honor in mourning as a prominent man. Moreover, a dirge is chanted here over a woman, an event unparalleled in all the biblical or later rabbinic literature. It seems that this dirge for a woman was composed by keening women, who naturally emphasized the feminine nature of the past events, including the dirge of Deborah. ${ }^{29}$

26 National laments were performed in the context of the temple cult where mourning was a daily ritual (though it is not known that women participated in these ceremonies). See M. Bar-Ilan, "Ofya u-mekora shel megillat ta anit", Sinai, 98 (1986), p. 114-137 (Hebrew, especially 130 ff). It is important to compare the performance of these laments to 1 Baruch 10:5, Baruch's lament over the destruction of the temple, a lament recited along with the people before the portals of the temple.

27 Another chapter that can be included in a discussion of feminine literary compositions is Judges 5, the Song of Deborah (see Chapter Four, below). For literacy among women in that period see Chapter Two.

28 For a review of the scholarship on this issue see A. Zeron, Sheetato shel ba'al kadmoniyot ha-mikra, (Ph.D. thesis submitted to Tel-Aviv University, 1973, Hebrew); D. J. Harrington, Pseudo-Philo, James H. Charlesworth (ed.), The Old Testament Pseudoepigrapha (Doubleday, Garden City, 1985), II, pp. 297 ff.

29 The "feminine" addition to Pseudo-Philo is evident in several aspects: 1) while the Bible records only the names of the sons of Adam, Pseudo-Philo explicity notes the 
The book also includes the dirge over the daughter of Jephthah, and tells the story of her life and what befell her. This additional information is unknown from any other source. ${ }^{30}$ First, it is interesting to compare the number of verses devoted to the different events, appearing first in the biblical account and then in pseudo-Philo. Judges 11 devotes 40 verses to the story, 33 of which deal with Jephthah and 7 with his daughter. By contrast, chapter 40 in pseudo-Philo, the parallel apocryphal account, recounts the story in 20 long verses, ten of them devoted to Jephthah, and ten to his daughter. The author felt that it was incumbent upon him - or her - to expand this biblical female character, the daughter of Jephtah. In the apocryphal account she is no longer anonymous, referred to no longer only as her father's daughter but by her

names of his daughters too, and the names of the daughters of all the forefathers of the first generations (Bib.Ant.. 1-20.2) The prophecy of the wife of Re'u, Milham daughter of Ruth (the prophetess!) tells of the birth of Abraham "Seated in the divine seat" (Bib.Ant.. 4:11). On Abraham's celestial seat see M. Bar-Ilan, "Kisse hashem: ma shemitahtav, ma shekenegdo uma sh-etzlo", Da'at, 15 (1975), pp. 21-35 (especially pp. $31 \mathrm{ff}$ Hebrew). 3) Samson's mother, in addition to having a vision of an angel, also prays (42:1; See below, Chapter Four). 4) Delilah is called a prositute, a demotion in the status of the gentile woman (43:5). 5) Tamar's deed is justified: "As she did not wish to remove herself from the children of Israel" (ibid. 9:5), 6) The mother of Micah (Judges 17:1-5) pressures her son to transgress and make idols, until she is finally punished severely (ibid. 44:1-9). 7) The lament over Deborah. 8) The lament over the daughter of Jephthah (below). 9) The words spoken by Penina to Hannah, her rival (1 Sam. 1:6) . 10) the name of the seer Sadakla daughter of Adod the Mideanite appears, showing that any sorceress in the land would clearly not be an Israelite (44:3). There is no doubt that these additions about women are much more significant than the additions about men, and they all aim at showing women in a better light. See also: Betsy Halpern-Amaru, "Portraits of Women in Pseudo-Philo's Biblical Antiquities," Amy-Jill Levine, (ed.), "Women Like This": New Perspectives on Jewish Women in the Greco-Roman World (Scholars Press, Atlanta, Georgia, 1991), pp. 83-106; Cheryl Anne Brown, No Longer Be Silent (Westminster/John Knox Press, Louisville, Kentucky, 1992), pp. 212-219.

30 For a partial discussion of the story see L. Ginzberg, The Legends of the Jews, IV (The Jewish Publication Society of America, Philadelphia, 1954), pp. 43-47; VI, pp. 203-204. The story is also included in The Chronicles of Yerahmiel (a medieval manuscript), discussed by Zeron (above note 28), p. 23 ff.) in M.Y. Ben Gurion, Memekor Yisrael, I (TelAviv, 1939), pp. 73-74 (Hebrew). For the parallelism between the lament and the literature and epitaphs of the classical world, see Margaret Alexiou and Peter Dronke, "The Lament of Jephtha's Daughter: Themes, Traditions, Originality", Studi Medievali, 12 (1971), pp. 819-863. Ginzberg and Zeron ( p. 37) are correct in reading "mountain of snow" instead of Satlah or Satlag. We have here, then, a tradition identifying Mount Hermon as the site where the daughter of Jephthah and her companions lamented. Cf. also Ginzberg (contrary to pseud-Philo) that women do not celebrate four consecutive days a year, but rather, one day at the start of every season. This mode of celebration is obviously much easier for a woman who must tend to her household, as an absence of one day four times a year is more logical than an absence of four consecutive days. Compare it to another custom of mourning (gathering tears in a bottle at the tomb of the deceased) in pseudo-Philo 82:9 and Zeron's remarks (p. 232, note 1). 
own name, Shaila, ${ }^{31}$ in accordance with the custom in apocryphal literature to state names of women, whereas the Bible is less likely to do so. ${ }^{32}$

The story is basically similar to the one in Judges: Jephthah's daughter, accompanied by other women, greets her father. After Shaila finds out that her father intends to sacrifice her, she consults the elders, seeking to be saved, but the men cannot help her (by God's wish). God calls Shaila "wiser than her father and a wiser virgin, more than the elders," and before her death she keens over herself in the following words: ${ }^{33}$

Hear, you mountains, my lamentation; and pay attention, you hills, to the tears of my eyes; and be witnesses, you rocks, of the weeping of my soul.

Behold how I am put to the test!

But not in vain will my life be taken away...

But I have not made good on my marriage chamber, and I have not retrieved my wedding garlands.

For I have not been clothed in splendor while sitting in my woman's chamber,

And I have not used the sweet-smelling ointment...

O Mother, in vain have you borne your only daughter,

because Sheol has become my bridal chamber,

and on earth there is only my woman's chamber.

And may all the blend of oil that you have prepared for me be poured out, and the white robe that my mother has woven, the moth will eat it.

31 This is how the name appears in Chronicles of Yerahmiel (above, and see Ginzberg). The Hebrew form would seem preferable to the Hellenized form of Saila as it appears in Hartom's edition. Saila is the feminine form of Saul (I Sam. 1:20). "She named him Samuel, meaning, 'I asked the Lord for him" (see 1 Sam. 1:28. The midrash clearly refers to the name Saul and not Samuel).

32 Cf, for instance, Sitis, Job's wife in the apocryphal Testament of Job 39:1; 2 Enoch 33:1, where Zofanima, wife of Nir, the priest, bore Malchizedek without having relations with her husband; The Book of Jubilees, chapter 4 is the sole source for the names On and Azora, daughters of Eve; Naomi; Mahalalit; Dina, daughter of Berakhiel; Berakha, daughter of Rezuel; Edna, daughter of Daniel; Batnush daughter of Berakhel, wife of Lemech; Amzarra wife of Rekhael, wife of Noah. For unknown names of women of the biblical period (apparently a translation from a lost apocryphal book) see A.A. Harkavy, Hadashim gam yeshanim (Jerusalem, 1970), p. 102 (Hebrew). This practice of inventing women's names was meant, apparently, to correct the masculine bias in biblical literature that habitually records only names of men. Indeed, the practice of inventing names existed in rabbinic literature as well, though on a more limited scale. In b. Bava Batra 91a we read: "R. Hanan b. Raba further stated in the name of Rab: [The name of] the mother of Abraham [was] Amathlai the daughter of Karnebo, [the name of] the mother of Haman was Amathlai the daugther of Orabti... The mother of David was named Nizbeth the daughter of Adael... In what [respect] do [these names] matter? - In respect of a reply to the heretics." That is: heretics such as those who believed in the book of Jubilees and those with a Hellenistic education, well-versed in the works of Homer, asked the sages for the names of the women mentioned anonymously in the Bible, forcing the sages to address the issue.

33 This lament preceded the actual death. Similarly, there are prophetic laments in which the prophet laments an expected death. See Tigai, column $131 \mathrm{ff}$. 
And the crown of flowers...

and the coverlet that she wove of hyacinth...

And may my virgin companions...

You beasts of the forests, come and bewail my virginity...

This unique feminine dirge is fittingly attributed to the first keening woman, Jephthah's daughter. ${ }^{34}$ It is of course difficult to ascertain the original version in any degree of exactitude, as the text has passed through several translations, but it does preserve biblical linguistic usage. The opening of the dirge resembles that of the song of Moses at the crossing of the Red Sea, and it goes on to request that the words of the dirge be put in writing, again recalling the song of Moses and other biblical passages that were first recited aloud and then set down in writing. The second half of the dirge is reminiscent of the opening of Job's elegy (Bib.Ant. 3:3), continuing with pairs of parallels, for example, "the oil will be spilt / the garment eaten away."

Literary analysis shows this elegy to be entirely feminine; even if it was not, in actual fact, a keening woman or feminine author who composed this text, at any rate it possesses the distinctive feminine mark. ${ }^{35}$ If a man composed this elegy, he must have been a professional keener who could imitate the feminine style. ${ }^{36}$ However, the juxtaposition of the elegy of the daughter of Jephthah with that of Deborah, as the two quintessential feminine elegies - though they may have nothing else in common- hints at their feminine composition. Even if the author was a man, he drew upon and borrowed words and phrases used by women keeners in his time, and put them in the mouth of Jephthah's daughter. Another possibility arises, in light of the book's feminine attributes; namely, that pseudo-Philo in its entirety was composed by women, but this claim would be hard to prove. ${ }^{37}$

34 Again, it must be stressed that neither the Bible nor pseudo-Philo view the daughter of Jephthah in this light, and the attribution to her of instituting the art of keening among the daughters of Israel is the work of modern scholarship. However, the pseudoJonathan translation to Gen. 4:22 says of Na'ama: "she would say laments and songs" (in line with the suggestion brought above of identifying the singer with the keener). That is to say, according to the Eretz-Israel tradition from about the same time as pseudoPhilo, Na'ama was the first keening woman in the world.

35 The feminine elements of the lament are: daughter, myrrh, oil, mother, girl, white garment, nursing, virgins, virginal. Clearly the sole interpretation is of a lament of a virgin who died before her marriage ceremony. On laments for virgins and other aspects of the lament see: Pieter W. van der Horst, Ancient Jewish Epitaphs (Kampen: Kok Pharos, 1991), p. 64.

36 Hannah's hymn (1 Sam. 2) is more a paean of triumph: ("I gloat over my enemies"; "The bows of the mighty are broken," etc.). See Chapter Four, below.

37 Pseudo-Philo paraphrases of the biblical narrative (and as such is not inherent ly different from Yiddish compositions in Me'a She arim meant for women. This 
Now, after examining the pseudepigraphical laments of Deborah and the daughter of Jephthah, let us look at another apocryphal composition that has preserved traces of keening by women, even of a dirge over a woman: the pseudepigraphical Testament of Job. It has been claimed that this was originally written in Greek, though there is no proof of this; it dates from about the start of the first century в.C.E. or the following century. 38

We will recall that the biblical book of Job ends with Job having lost his seven sons and three daughters. By way of unusual deviation from custom, the three daughters are introduced by name while the sons are not (Job 42:13-15). ${ }^{39}$ Then Job's age is stated, and the biblical book con-cludes: "So Job died old and contented." The pseudepigraphical book, on the other hand, adds several details, including that Job's “... body, prepared for burial, was borne to the tomb as his three daughters went ahead girded about and singing hymns to God" (Testament of Job, 52:11). ${ }^{40}$ That is, the daughters alone, without the sons, lamented over their deceased father.

The author, under the assumed identity of Nereus, Job's brother, informs the reader that he and the seven sons chanted elegies over Job, and quotes them:

Woe to us today! A double woe!

Gone today is the strength of the helpless!

Gone is the light of the blind!

comparison, along with the feminine aspect of the composition, leads to the hypothesis that pseudo-Philo is a translation or synopsis written by a learned woman for other women (even if the original composition was written in Hebrew). The unique style of pseudo-Philo is clearly evident when compared to the book of Jubilees . The latter also presents a synopsis of the biblical stories, but includes many halakhot and emphasizes the Jewish calendar. The halakhic nature of the composition locates it in a different genre altogether.

38 See Y. Licht, "Mashma`o shel sefer tsava'at iyov", Sixth World Jewish Congress, I, (Jerusalem 1977), pp. 147-152 (Hebrew); Pieter W. van der Horst, "Images of Women in the Testament of Job", Michael A. Knibb and Pieter W. van der Host (eds.), Studies on the Testament of Job, (Cambridge University Press, Cambridge, 1989), pp. 93-116.

39 Num. 27:1 ff. mentions the names of the five daughters of Zelophehad (he had no sons) who demanded their right to inherit his land. In addition to being mentioned by name, the daughters of Job were called the most beautiful in the land and "Their father gave them estates together with their brothers" ( Job 42:15). See also: Michael D. Coogan, "Job's Children”, T. Abush, J. Hushnergard and P. Steinkeller (eds.), Lingering Over Words in Honor of William L. Moran, (Scholar Press, Atlanta, Georgia, 1990), pp. 135-147. In any case, the ratio between the names of women and names of men is most unusual. On this ratio, see T. Ilan, "Notes on the Distribution of Jewish Women's Names in Palestine in the Second Temple and Mishnaic Periods", JJS, 40 (1989), pp. 186-200.

40 For the possibility that Testament of Job was written by a woman see Mary R. Lefkowitz and Ross S. Kraemer's works mentioned above chapter 2 n. 42. 
Gone is the father of orphans!

Gone is the host of strangers!

Gone is the clother of widows!

This masculine elegy follows along the lines of biblical elegies which enumerate the merit of the deceased and describe his good deeds, such as charity to widows. ${ }^{41}$ The present elegy has several innovations: at the death of Sitis, Job's wife (Bib.Ant.. 9:12-13): "the poor of the city made a great lamentation, saying 'Look! This is Sitis, the woman of pride and splendor! She was not even considered worthy of a decent burial!' So then you will find in 'The Miscellanies' the lament made for her." The author was aware of the existence of the elegy over Job's wife, but did not put it down in writing, just as he did not quote the prayers of the daughters, though he did set down their elegy. His reluctance to write a dirge over a woman is consistent with his attitude towards the song recited by Job's daughters just prior to his death, after their father had made his will known to them. In chapters 48-51 the author tells that "Hemera... spoke ecstatically in the angelic dialect, sending up a hymn to God in accord with the hymnic style of the angels. And as she spoke ecstatically, she allowed "The Spirit" to be inscribed on her garment." The author was aware, then, of Hemera's song but did not write it down. The same is true of his attitude to the second daughter, Kasia: "her mouth took on the dialect of the archons and she praised God for the creation of the heights. So, if anyone wishes to know "The Creation of the Heavens,' he will be able to find it in 'The Hymns of Kasia."' As to the third daughter: "Amaltheia's Horn... her mouth spoke ecstatically in the dialect of the cherubim, glorifying the Master of virtues by exhibiting their splendor. And finally whoever wishes to grasp a trace of 'The Paternal Splendor' will find it written down in "The Prayers of Amaltheia's Horn." The author concludes "I, Nereus, the brother of Job... I wrote out a complete book of most of the contents of hymns that issued from the three daughters of my brother, so that these things would be preserved. For these are the magnificent things of God" (51). He apparently believed that God should not be glorified by songs of women, and for this reason omitted their hymns of praise and glory to God, as he refrained from writing how Job's daughters lamented over their father.

41 This lament is similar to the biblical laments (and also to the talmudic laments, as we shall see below), in regards to the honorary titles and praise of the deceased, such as the cry "O" as an expression of mourning. Cf. Tigai. Job's kindness to widows and orphans are recounted in 13:4: how Job fed them delicacies, and even played music before the widows and the maidservants to lift their spirits (Job 14:1-5). 
The author of the Testament of Job does acknowledge a different feminine elegy over Sitis, Job's wife - not over her death but over the decline in her wealth, honor and glory. The author describes how Job lost all his wealth and went hungry, and how his wife sold her hair to Satan to feed her husband. The following lament over this incident is included here (in concise form TJ 25:1-7):

Who is not amazed that this is Sitis, the wife of Job?

Who used to have fourteen draperies sheltering her chamber and a door within doors, so that one was considered quite worthy merely to gain admission to her presence!

Now she exchanges her hair for loaves!

Whose camels, loaded with good things...

Now she gives her hair in return for loaves!

look at her who used to keep seven tables reserved at her house...

Now she sells her hair for loaves!

See one who used to have a foot basin of gold and silver...

Even her hair she gives in exchange for loaves!

Observe, this is she who used to have clothing woven from linen with gold... gives

her hair in exchange for loaves!

See her who used to own couches of gold and silver.

But now she sells her hair for loaves!

Although the word "lament" does not appear here explicitly, but the contrast between the glorious past and the bleak present shows that indeed it is a lamentation. Poverty was likened to death (b. Nedarim 64b) and a rich man who lost his wealth deserved to have laments said over him. The book tells of the lament of Eliphas over Job's loss of wealth (ibid. 32:1-12), and there the word "lament" does appear explicity:

Hear then the lament of Eliphas as he celebrates for all the wealth of Job:

Are you the one who appointed 7,000 sheep for the clothing of the poor?

Where then is the splendor of your throne?

Are you the one who appointed 3,000 camels for the transport of goods to the needy?

Where then is the splendor of your throne?

Are you the one who appointed the thousand cattle for the needy...

Where then is the splendor of your throne?

Eleven lines in the text emphasize Job's material decline, by recalling his past wealth..$^{42}$ The identical element in these elegies is that they are litanies in the form of a fixed (or nearly fixed) refrain said by the keeners in response to the words of the chief mourner. ${ }^{43}$

42 For more on contrasts in laments, see above, and cf. also 1 Baruch 35:1-5 Baruch's lament over the destruction of the temple: "O that my eyes were springs ...For at the place where now I am prostrate, the high priests used to offer holy sacrifices... Now, ...has become dust."

43 It is explained immediately following the lament (33:1) "After Eliphas (or: Elihu) finished wailing while his fellow kings responded to him all in great commotion." 
The lamentation over Sitis's material decline is reminiscent of Naomi, wife of Elimelech, arriving in Bethlehem with Ruth: "When they arrived in Bethlehem the whole city buzzed with excitement over them. The women said: "can this be Naomi?"' (Ruth 1:19). These words seem like traces of a women's elegy, used by the women of Bethlehem to mourn Naomi's downfall, similar to that of Sitis in our story. ${ }^{44}$ Women keened, then, not only over the dead, but also over a decline in fortune, as in the cases of Sitis and Naomi. Despite the reluctance of the pseudoepigraphical author of Job to quote the elegy said by Job's daughters over their father, he did nevertheless include a lamentation over Job's wife, apparently sung by women, and he does acknowledge that Job's daughters, separately from his sons, chanted dirges at his death. ${ }^{45}$

Following this review of the biblical and post-biblical literature, we now turn to literary evidence of keening women in the talmudic sources. 46

\section{Talmudic literature}

Jewish mourning customs in Eretz-Israel in the talmudic period are a case in point exemplifying the great importance of inter-disciplinary research and its contribution to the study of Talmud and to the social sciences. ${ }^{47}$ In the wider context of mourning customs in talmudic

44 Cf. the rhetorical cry, "Is this...?" like the cry appearing in other laments: "Is this the city that was called Perfect in Beauty, Joy of all the earth?" Lamentations 2:15; About Tyre: "Was such your merry city, in former times, of yore?" (Is. 23:7); "Is this the man who shook the earth?" (Is. 14:16). See also the rhetorical question "Where" in Job's lament. On the interrogatives how, however, in laments as expressions of sorrow, see Tigai, column 126 .

45 This composition, unlike the Bible, stresses the following feminine elements: a) Job had two wives, Sitis and Dina, daughter of Jacob. b) Sitis's words are set forth in detail, as are her prayer and the lament said over her. c) Sitis did a noble deed in selling her hair to buy bread for her husband Job (cf. above, note 9). d) There is a prohibition against marrying gentile women. e) The songs of Kasia and the prayers of Amaltheia's Horn, daughters of Job, are mentioned, and Hemera too sings before God. f) Job's daughters lament over their father.

46 It should further be noted that the Sybilline Oracles were composed by Jewish women in Alexandria (see Chapter Two), and their feminine origin is evident time and again from the text - the mention of women and virgins, and the fact that a prophetess is recounting her prophecies. Homer is called a false author, and another man is called untrustworthy. However, for the present discussion, it is important to note that several prophecies of the Sybillines were composed as laments opening with the words $O$ or $A h$. Keening women are described bewailing their shame at being forced into prostitution and the keening woman, it is written, accompanies herself with a musical instrument (ibid. 5:306). We will return to this point below.

47 N. Rubin, Defusei ha-evel ha-yehudiyyim be-eretz-Yisrael betekufat hamishnah vehatal- 
literature, there is some evidence of dirges and women keeners, but the scant mention made of them fails to reflect the continuity of Jewish traditions of the time of the Mishnah with previous periods. ${ }^{48}$ The participation of women in saying dirges and keening in the talmudic period was not a newly-introduced practice, but a continuation and perpetration of an ancient custom. Let us now turn to the talmudic sources to ascertain to what degree they preserved old customs.

Mishnah Mo'ed Katan 3:8-9 instructs how the laws of mourning are applied on a day of festival:

The women may sing dirges during the Feast but may not clap their hands. R. Ishmael says: They that are near to the bier may clap their hands. On the first days of the month and at [the Feast of] the dedication and at Purim they may sing lamentations and clap their hands; but during none of them may they wail. After the corpse has been buried they may not sing lamentations or clap their hands. What is a lamentation? When all sing together. And a wailing? When one begins by herself and all respond after her; For it is written, "Teach your daughters a lanent, and every one her neighbor wailing" (Jer. 9:19). But for a time that is to come, it says, "He hath swallowed up death for ever, and the Lord God will wipe away tears from off all faces; and the reproach of his people shall be taken away from off all the whole earth: for the lord hath spoken it" (Is. 25:8).

This Mishnah tells in detail how women would keen in that period; the conclusion of the passage with a biblical verse expressed the belief of the sage that these were ancient halakhot. A distinction is made here between festivals when deep mourning is forbidden so as not to cloud the festive atmosphere and minor festivals, when the sages permitted women to mourn the dead in their usual manner. The parallelism between beating the breast and chanting dirges indicates that it is part of the same action: the women would beat their breasts and lament like the ancient keening women in Isaiah 32:12: "Lament upon the breasts." That is, women would beat the breast to express grief when keening. ${ }^{49}$

Some light can be shed on the custom of keening by our knowledge of the mode of chanting in the time of the sages. A song is joyful, while a dirge is mournful, and it has already been remarked that women had

mud (Ph.D. thesis for Bar-Ilan University, Ramat-Gan 1977), p. 305 ff. (Hebrew).

48 S. Safrai, beshalhei ha-bayyit ha-sheni u-vetekufat ha-mishna, ${ }^{2}$ (Jerusalem, 1983), pp. 82-83 (Hebrew).

49 This interpretation appears already in Tosefta Mo'ed 2:17: "What is a lamentation? This is one which is upon the heart, as it is said, 'Beat upon your breasts' (Is. 32:12). Clapping is with the hands. A gesture of praise - this is the spreading open of the arms" (Neusner, Ktav, New York 1981). So, lamentation, clapping and beating the breast are one and the same; though the first two refer to the external appearance, all refer to the same ceremony. We learn by the way of another custom, of spreading the arms while praising the deceased (while walking, in a kind of dance.) 
a prominent role in singing hymns of joy as well as dirges in times of grief. In Tosefta Sota several traditions tell of how songs were sung among the Israelites, and all would seem to reflect forms of singing in the tannatitic period:

Expounded R. Aqiba: "When the Israelites came up from the sea, they wanted to proclaim a song. "The Holy Spirit rested on them and they thereby proclaimed their song. "How did they say that song? Like a child who recites the Hallel in school. "And they answered him [by repetition] of each and every phrase.

"Moses said, "I shall sing unto the Lord (Ex. 15:1), and the Israelites answered him, "I sill sing unto the Lord."

"Moses said, ' My strength and my song is the Lord,' (Ex. 15:2), and the Israelites said, 'My strength and my song is the Lord.'

R. Eleazar b. R. Yose the Galilean says, 'They proclaimed the song like an adult who proclaims the Hallel in synagogue-worship, responding to him with the foregoing phrase, as follows: "Moses said, 'I will sing to the Lord,' (Ex. 15:1), and the Israelites said, 'I will sing to the Lord.' Moses said, 'My strength and song is in the Lord; and the Israelites said, 'I will sing unto the Lord.

Moses said, 'The Lord is a man of war, ' (Ex. 15:13), and the Israelites said, 'I will sing unto the Lord.'

R. Nehemiah says, [They proclaimed the song] like men who recite the Shema in synagogue- worship, as it is said:

'And they said, saying (Ex. 15:1). This teaches that Moses would open first with a given matter, and the Israelites would respond to him and complete saying [that same matter, thus:] Moses said, 'Then Moses sang,' and the Israelites said; I shall sing unto the Lord: Moses said, 'My strength and song is the Lord,' and the Israelites said,'This is my God and I will glorify him. Moses said, 'The Lord is a man of war,' and the Israelites said, 'The Lord is his name.'

(The Tosefta, tr. Jacob Neusner, New York: Ktav, 1979, Sota 6:2-3)

The three tannaitic approaches, then, reflect three modes of reciting prayers in the second century C.E. in Eretz-Israel. ${ }^{50}$ The chants of Moses and the children of Israel followed the leader/congregation format, but the rabbis differed as to the precise procedure. According to R. Akiva, the congregation repeated the words of the leader. According to $R$. Eleazar, son of R. Yossi the Galilean, the leader would chant first, and the congregation would respond with the same fixed litany each time. According to R. Nehemia, each verse was divided in two measures: the first measure was recited by the leader, and the congregation supplied the second measure. This manner of chanting is described at the end of the hymn of the Crossing of the Red Sea: "Then Miriam the prophetess, Aaron's sister, took a timbrel in her hand, and all the women went out

50 See M. Bar-Ilan, Sitrei tefillah ve-heikhalot (Ramat-Gan, 1987), p. 17 ff. (Hebrew), especially about ancient litanies and the literature discussing them. See also Batya Bayer, "Shirat ha-ma'ane etzel anshei kat midbar yehudah", Dukhan, 9 (1972), pp. 1112; S. Lieberman, Mehkarim be-torat Eretz-Yisrael (Jerusalem, 1991), pp. 192-193 (Hebrew). 
after her in dance with timbrels. And Miriam chanted for them: Sing to the Lord, for He has triumphed gloriously; horse and driver he has hurled into the sea" (Ex. 15:20), with Miriam chanting aloud and the other women responding. The sages assumed that the pattern of the song of the women was similar to that of the men, so that their description of the song of Moses would hold true for Miriam and her song as well. The dirge, then, in which "one woman speaks and the rest respond after her" was one of the customary forms of song. One woman would lead in reciting the dirge: she would chant one verse and the other women would repeat it after her. When it was a familiar text, the keening woman would recite one part of the verse, and the others would respond with the second half. At times the second half of the verse was a fixed litany, as in the dirge over the downfall of Sitis in the pseudo-epigraphic Testament of Job. Both forms left their mark in biblical and apocryphal dirges composed of verses divided into two parts.

In contrast to the leader/response form of the dirge, there was also a form of mourning in which all would chant amid wailing and crying, without leader or response. This was a more subdued, less public form of mourning, and due to the restraint it showed was permitted on lesser festivals, since it did not cloud the festive spirit. Expressions of deep, dramatic grief such as "foot-stamping" (kilus haregel) $)^{51}$ were forbidden. 52

The custom of women keening and chanting dirges is an ancient one, ${ }^{53}$ and the main innovation introduced by the sages was the restriction of their keening to certain days.

Another mourning custom related to keening in the talmudic period appears in $\mathrm{m}$. Ketubot $4: 4$ in a discussion of the rights of women:

51 Mo'ed Katan 27b: “...tippuah is clapping one's hands [in grief], ... killus [is tapping] with the foot [in mourning]. Our Rabbis taught: One who does the tapping with the foot should not do so when wearing either sandal or boot, because of the danger." $C f$. N. Rubin (above, n. 46), p. 313. It seems that this was a regular, rhythmic foot-tapping, like the litany, on one hand, and like the dances of mourning mentioned above, on the other hand. Stamping the foot during mourning is mentioned already in Ez. 6:11: "Strike your hands together and stamp your feet and cry: Aha!"

52 It must be remembered that women keened separately from the men, either walking before the bier of the deceased or behind it. At no time did they mingle with the men (this bears implications for the issue of praying separately). See N. Rubin (above, n. 46), p. 306; Louis M. Epstein, Sex Laws and Customs in Judaism (Ktav Publishing House, New York, 1967), p. 68 ff.

53 For further discussion of innuy -"suffering"- cf. above, regarding Elihu's lament over Job and Berakhot 62a: "Because it has been taught: Just as the dead are punished, so the funeral orators are punished and those who answer [Amen] after them." The lament, then, was usually performed with a response (fixed or changing) though there is no biblical evidence of this other than the Testament of Job. 
$R$. Judah says: even the poorest in Israel should hire not less than two flutes and one wailing woman (Danby, p. 250).

If the words of $\mathrm{R}$. Judah are taken as a reflection of historical reality, it follows that there was at least one woman who was designated as keener at every funeral in the time of the Mishnah, as well as two flautists, perhaps also women. ${ }^{54}$ If this was true of a pauper's funeral, there presumably were even more women keening at more affluent funerals.

The keeners were often women, a custom perpetuating the practice of the biblical period. ${ }^{55}$ This continuity is evident not only in the external form of the dirge but also in its content. We find these words of praise spoken by R. Ishmael: “"The daughters of Israel are comely but poverty destroys their comeliness!' And the tanna adds: "When R. Ishmael died the daughters of Israel raised a lament, saying, 'Ye daughters of Israel, weep over R. Ishmael!' So, too, it is said of Saul, 'Ye daughters of Israel, weep over Saul"' (m. Nedarim 9:10). The women in time of the Mishnah continued the example set by their biblical fore-mothers at the death of Saul, keening over the death of the tanna who had praised their beauty. This then constitutes an imitation of the genre of biblical elegy, not an independent literary work like the other dirges we have discussed. It should also be noted that traces of twenty-nine dirges are to be found throughout talmudic literature, only seven of which were composed by women. ${ }^{56}$ The writers of the Talmud related to feminine creativity as did the author of the pseudo-epigraphical Testament of Job, i.e., by ignoring women's elegies. ${ }^{57}$ It is therefore not surprising that even the dirges that did survive do not derive from Palestine but from Babylonia, and date from the third and fourth centuries C.E. Even if there is a shift here from Palestine to Babylonia, women were evidently active in both places. As funerary customs are an element that exhibits similar traits in different places and is slow to change, these Babylonian elegies, too, should be a subject of our study.

The discussion of keening women in b. Mo'ed Katan 28b lists eight laments, one anonymous and the other seven attributed to the women

\footnotetext{
54 On the flute in the talmudic period, see Rubin (above, n. 46), p. 317 ff., who brings a description of a Roman sarcophagus with a relief of a woman playing the flute.

55 See Safrai (above, n. 47) and Ecclesiastes 12:5: "With mourners all around in the street." Talmudic literature speaks of lamenters, not keeners, indicating that the acts of the keening women were somewhat different from those of the male lamenters. Safrai's conjecture "that keeners were always women, more fluent in Aramaic" is not borne out by the sources.

56 A review of all the laments in the Talmud can be found in E. Feldman, "The Rabbinic Lament", JQR, 63 (1972-73), pp. 51-75.

57 Cf. the eulogies of the rabbis (not keening) in y. Berakhot $1: 3,4, a-b$.
} 
of Shoken-Zeb in Babylonia (the first one appears in duplicate). These elegies are all very brief, written in Aramaic, and employ rare linguistic collocations. ${ }^{58}$

Said Rab: Cry woe o'er him that is now departing; Cry woe o'er his wounds and smarting!

Raba also said: the women of Shoken-Zeb speak thus: Cry woe o'er him that is now departing! Cry woe o'er his wounds and smarting!

Raba also said: The women of Shoken-Zeb speak thus:

Withdraw the bone out from the pot

And the kettles fill with water [hot]. 58

Raba said this also: The women of Shoken-Zeb speak thus:

Be muffled, ye high mountains, [Clouds] covering your head of high lineage and great ancestry

Came he that is dead.

Also this said Raba: The women of Shoken-Zeb speak thus:

Borrow [and buy] a Milesian robe

To dress a free-born son,

Give it free of charge for

Provision left to none.

And furthermore said Raba: The women of Shoken-Zeb speak thus:

Come hurrying and scurrying tumbling about the ferry and having to borrow his fare .

Again this said Raba; The women of Shoken-Zeb said thus:

Our brothers are merchants who At the custom house are searched .

And again said Raba: the women of Shoken-Zeb speak thus:

This death or that death is the end of the guest. Our bruises are the rate of interest. ${ }^{59}$

There is probably no other passage in the Talmud quoting women so extensively. Clearly, if Raba quoted the women of Shoken-Zeb, it is because they were famous for their wisdom and especially for their expertise as keeners. It should be noted that every dirge, as brief and unclear as it may be, seems designed for a different occasion. This means that we have a collection of elegies chanted by the same group of keeners on different occasions. The lines of the elegies are composed of two parallel measures in the style of biblical and post-biblical elegies. Moreover, their special quality of wisdom is noteworthy, indicating that the Jewish women of Babylonia made intelligent and clever use of the Aramaic language just as their predecessors in Palestine employed unique collocations of the Hebrew language, be it the keening women in the book of Lamentations, or the wise woman of Tekoa. The traces of

58 Text and language are difficult, and I have used the more likely interpretation here, following B. M. Levine, Otzar ha-geonim, I, Hagiga Yom Tov u-mashkin, (Jerusalem, 1931), pp. 72-73 (Hebrew) and other commentaries.

59 Rabbi Shimon Ben ha-Yatom writes in Otzar ha-geonim: "Know: the words of the these women are deep of language and more difficult than any riddle, since they speak in complex riddles, remove the spirit from a man and he returns to be dust." For other interpretations, see: S. Sekles, The Poetry of the Talmud (New York, 1880), pp.48-50. 
elegies remaining from the women of Shoken-Zeb can tell us something of the wisdom and expertise of the keening women in Palestine in the period of the Mishnah and Talmud.

\section{The social aspect}

Scholars of the social sciences have long been aware that funerary and burial customs were transmitted from one culture to another, transcending geographical borders and religious differences, and endured for thousands of years. This seems to be part of human nature that strives to preserve archaic customs in funerary rites, one of the three major phases of the human life-cycle: birth, marriage and death. The funeral ceremony reflected one's social status by the choice of place of burial, the show of wealth displayed in the funeral procession, and the number of mourners. ${ }^{60}$ The presence of keening women was an inseparable element of social behavior for bewailing the deceased. In the biblical period women performed upon occasions of joy as well as of sadness, before audiences of men and women. They proved their equality and in a sense even their superiority in ability to keen over the dead. But the words of the prophet Zechariah reveal that women would keen separately from men, and the separation of the sexes signifies the tendency of traditional societies to uphold modesty and mark a clear delineation of the feminine role at funerals. 61

While women in the biblical period could participate in occasions of national joy or mourning and not only in private ceremonies of marriage or death, in the talmudic period we hear mainly of women keening and less of participation in joyful national affairs such as the hymn of Miriam or Deborah. This is probably due to the lack of national celebrations after the destruction of the Temple, and women's status as leaders in joyful ceremonies suffered as a result. The only social ceremony in which the Jewish woman participated was the funeral - only there was she permitted to appear in public and express herself, not only in wailing and heart-rending sobbing, but also in the literary composition of elegies chanted aloud. This allowed women to eulogize the deceased, and at the same time, to give free rein to their creativity. The elegies

60 W. M. Kephart, "Status after Death", American Sociological Review, 15 (1950), pp. 635-643; Effie Bendann, Death Customs (Dawsons of Pall Mall, London, 1969), pp. 225-234. See also M. Bar-Ilan, "Ha-kevurah benahalat avot bein hayehudim ba-et ha-atika," I. Zinger (ed.), Kevarim ve-nohagei kevura be-Eretz Yisrael baet ha-atika (Jerusalem, 1994), pp. 212-229 (Hebrew).

61 Cf. for instance Bendann's book (pp. 238-244) on the special role of women in funerary customs in different cultures. 
won a place of honor in the eyes of the talmudic sages, who departed from their usual practice and quoted female elegies as an example of the literary talent of women.

In different periods men as well as women engaged in keening. But Jeremiah's summons to women, not men, and the nature of the talmudic evidence, show that the affiliation of women with keening was stronger than that of men. It is possible that the close link between women and keening developed out of the identification of women with crying and sentimentality; this form of behavior was seen as an advantage over men in the context of triggering or heighteing exhibitions of grief. Perhaps it was considered more appropriate for women to accompany a person departing from the world, just as they welcome one into it, thus closing the cycle of life. ${ }^{62}$ Yet another explanation can be offered for the inclusion of women in ceremonies of keening, a social exhibition that is unparalleled in antiquity. Traditional society tends to fear the sexual threat posed to men by a woman appearing in public, and perhaps the realization that the sexual drive is depressed in the presence of death led to the permission extended to women to appear in public. ${ }^{63}$ Faced with death, femininity has not the sexual threat of seduction for men, and perhaps even has an advantage, due to the highpitched female voice that can pierce the noise of the crowd. The traditional society that preferred as a rule to keep women at home encouraged them to participate in keening ceremonies as a sign of justice to the deceased. ${ }^{64}$ There is some intimation here, perhaps, of the primeval link with the supernatural that society attributes to women. ${ }^{65}$

62 Gen. Rabbah 17:8 (Midrash Rabbah, tr. H. Freedman, London and Bournemouth: Soncino Press, 1951) "Why do they [the women] walk in front of the corpse [at a funeral]? Because they brought death into the world, they therefore walk in front of the corpse."

63 Shmuel's remark "A woman's voice is a sexual incitement" contradicts longstanding Jewish tradition, though a similar opinion can be found in Greek thought. See E. E. Halevi, Arkhei ha-aggadah ve-ha-halakha, IV, (Tel-Aviv, 1982), p. 205 (Hebrew). In any case, even one claiming that "a woman's voice is a sexual incitement" admits that this rule is inapplicable in the cemetery. See b. Kiddushin $80 b$; y. Kiddushin 4:11, 66c: "For sexual desire is uncommon in a graveyard." and b. Sukkah 52a: “...when they will be engaged in mourning and the Evil Inclination will have no power over them."

64 Cf. Pirkei de-R. Eliezer 17: ( tr. Gerald Friedlander, Hermon Press, N.Y. 1965, p. 116). "Where do we learn (the duty of) showing loving-kindness to mourners? From Jezebel, the daughter of Ethbaal. The palace of Jezebel, daughter of Ethbaal, was near the market-place. When any corpse was carried through the market-place, she would go forth from her palace, and she clapped with the palms of her hands, and praised with her mouth, and she followed the corpse ten steps." I do not know by what process Jezebel was transformed into a righteous woman, but the story does present a portrait of a righteous woman.

65 For example, a sorceress, see Chapter Five, below. 


\section{Conclusion}

We know of keening women in the Ancient Near East and in biblical, apocryphal and talmudic literature. An analysis of the dirges in which women participated shows these dirges to be feminine works, literary evidence of the verbal strength of women in antiquity. Dirges by women and over women express the status of women in antiquity, perhaps as an example of their full integration in society.

The significant contribution of apocryphal literature once again provides insights into the historical and cultural gaps between the biblical and talmudic literatures.

Women who keened over the dead formed a kind of sisterhood, demonstrating their intellectual prowess separately from the men. This custom of mourning continued from antiquity almost to our day, though in most Jewish communities the custom of keening has long since disappeared, and only men eulogize the deceased. ${ }^{66}$

66 On modern keening women (ancient traditions has been preserved more faithfully in this than in other areas) in Yemen, a Jewish society that preserves traditions dating as far back as the talmudic period, see Y. Kappah, Halikhot Teiman (Jerusalem, 1968), p. 248 (Hebrew): "The women break out in terrible wails and shrieks, saying laments and eulogies in rhymes, as the literary spirit takes them.... The close friends and acquaintances from the entire city, and any woman in sad spirits, come there, each raising her voice in wails and rhyming rhymes. The lament always recounts praises of the dead person, his qualities and life, his behavior with other people, his wisdom and learning and the terrible tragedy of the family and society caused by his death, etc." Rabbi Kappah then presents an acrostic on the theme of theodicy (cf. the book of Lamentations) and remarks: "If they reached the end of the alphabet and still did not finish dressing him... they repeat the alphabet again in the same fashion." Cf. also to the lament over women in Tikhlal Yerushalayim, ed. S. Garami (Jerusalem $1889=$ Jerusalem 1988), I, p. 141. 


\section{CHAPTER 4}

\section{Prayers by Women}

In Judaism, as in other religions, women as well as men pray to God; in the Jewish tradition from biblical times to the present day, however, women's prayers have never attained definitive status. This chapter deals with the status of women's prayers in antiquity, working with a loose definition of what constitutes a prayer. The purpose of the discussion is to address the wealth of information on this subject in the Bible, in apocrypha and in talmudic literature. Following a survey of the prayers, their feminine nature will be analyzed - insofar at such can be said to exist - as well as their role in daily life. It will become clear that a close study of women's prayers in the social context can illumine the women's relationship with God and the relationships in the community of women. The purpose of the textual analysis of women's prayers is to lead to an historical understanding which may help establish the status of women in antiquity in Judaism.

\section{In the Bible}

Among the myriad prayers mentioned in the Bible, only a small number were said by women. ${ }^{1}$

\section{Miriam}

It will be recalled that after the Israelites crossed the Red Sea and were rescued from the pursuing Egyptians, Moses sang a hymn of praise to God (Ex. 15), ending in the following words:

Then Miriam the prophetess, Aaron's sister, took a timbrel in her hand, and all the women went out after her in dance with timbrels. And Miriam chanted for them: "Sing to the lord, for He has triumphed gloriously; Horse and driver He has hurled into the sea" (Ex. 15:20-21).

1 M. Greenberg, "Tefillah," Encyclopaedia Mikrait, VIII (Jerusalem,1972), columns 896922 (Hebrew); M. Greenberg,, Harzaot al ha-tefillah bamikra (Academon, Hebrew University, Jerusalem, 1971, Hebrew); J. Muffs, "Bein din lerahamim: Tefillatan shel Nevi'im", A. Shapira (ed.), Torah Nidrashet (Tel-Aviv, 1974), pp. $39-87$ (Hebrew); M. Greenberg, Biblical Prose Prayer (University of California Press, Berkeley and Los Angeles, California, 1983). 
These verses record how women sang after the fashion of men, with Miriam "chanting," that is, speaking the words aloud, and "all the women" repeating her words after her. ${ }^{2}$ The women imitated the actions of the men and chanted praise to God, separately from the men. As Moses led the men in song, so Miriam led the women, though the women surpassed the men in praising God: the men only sang, while the women accompanied their victory dance with drums. This prayer by women is not distinguished by any feminine mark, and does not indicate anything of Miriam's function as prophetess. ${ }^{3}$

\section{Deborah}

Besides being a prophetess, Deborah was also a judge and a military leader. Judges 4-5 gives two versions of the victory of the Israelite tribes over King Jabin of Hazor: one in prose, the other in verse. ${ }^{4}$ Deborah encouraged Barak, the son of Abinoam, to battle against Sisera, Jabin's general, and Barak proceeded to defeat the Canaanites. However, it was not he who killed Sisera but Jael, the wife of Heber the Kenite. Following the prose account of events, Deborah sings her famous hymn, on which much has been written. ${ }^{5}$ We shall now examine the feminine aspects of this hymn.

The hymn opens with the following words: "On that day Deborah and Barak, son of Abinoam, sang": Deborah is the main agent here, and Barak is secondary. There are two self-reflexive references by Deborah in the hymn: "Till you arose, O Deborah, arose, O mother, in Israel!" and "Awake, awake, O Deborah! Awake, awake, strike up the chant!" We have here a hymn sung by a woman who appreciates her own value and expresses her femininity by specifying her name and her status as "mother" in the chant. The singer-prophetess continues: "Arise, $\mathrm{O}$

2 Certain prayers were said in this fashion, cf., for instance: Ps. 88:1: "A song. A psalm of the Korahites. For the leader; on mahalath leannoth. A maskil of Heman the Ezrahite", and the psalm continues with verse lines comprising two parallel measures. See above, ch. 3 .

3 Not only that: when Miriam does finally speak (about the wife of Moses), she is reprimanded and punished by God. See Num. 12:1-15.

4 On the issue of two versions, one prose and one verse, see M. Bar-Ilan, "Ve-samu et shmi al benei yisrael (Num. 6:27)," HUCA, 60 (1989), Hebrew section, pp. 19-31.

5 We cannot refer here to the wealth of literature dealing with the Song of Deborah, but it seems that very little attention has hitherto been paid to the feminine nature of the song. See: Y. Ikada, "Shirat Devorah ve-shivtei Israel", H. Rabin (et al., eds.), Sefer Meir Wallenstein (Jerusalem, 1979), pp. 65-79 (Hebrew); Danna Nolan Fewell and David M. Gunn, "Controlling Perspectives: Women, Men, and the Authority of Violence in Judges 4 \& 5", Journal of the American Academy of Religion, 58/3 (1990), pp. 389-411. 
Barak; take your captives, O son of Abinoam!"; the woman here gives orders to the man (or, at the very least, spurs him on); perhaps otherwise the men would not go to war at all. Deborah also criticizes those tribes that refrained from taking part in the battle (Reuben, the inhabitants of Gilead and others). She shows that divine justice is on her side - the woman's - not the men's. She goes so far as to belittle the strength of the men in war. The battle was in reality fought not by the men but rather: "The stars fought from heaven, from their courses they fought against Sisera." In fact, there was no need for men at all, since "The torrent Kishon swept them away," meaning that the forces of nature, directed by God, won the battle, not the men-warriors. The men were at first pawns in the woman's hand; she spurred them on to battle, then as executors of God's will. It is therefore not surprising that the prophetess praises another woman - the cowardly men did not go to war, while Jael killed the enemy. She is the true heroine and as such is deserving of praise. ${ }^{6}$ Seen from this perspective, the world revolves around women. The prophetess derides her enemies; no such taunts are evident in her feelings towards the king or his sons, the general or the fallen soldiers. Her gaze is turned rather to a woman or a group of women: "Through the window peered Sisera's mother, behind the lattice she whined... The wisest of her ladies give answer; She, too, replies to herself..." This is a dirge sung by the enemy women, in contrast to the victorious elation of the Israelite women. The hymn shows that war waged by men is no war at all, and the grief (of the fathers of the fallen warriors) is not genuine. As if all this were not enough, the prophetess continues: "They must be dividing the spoil they have found: A damsel or two for each man," i.e. the real spoils of the war are not gold; a woman is the best prize a man can win. In the world-view of the prophetess, judge and singer, men came a definite second. ${ }^{7}$

No other hymn in the Bible accords such emphasis to the role of women in achieving victory or to the grief of the enemy. Even if the name of the singer had not been lost, it would have to be said that a clear feminine perspective comes to the fore in this victory song. ${ }^{8}$ Modern literary analysis, however, is misleading: had we possessed only Judges $4-5$ out of the entire Bible, and considered it as typically

6 See above, ch. 1, on Jael's courage.

7 See Y. Dvir, Yi udah shel ha-Shlihut bashem ha-mikrai (Tel-Aviv, 1969), p. 105 ff. (Hebrew).

8 We cannot subscribe to A. Steinzaltz's definition that "Deborah's song is one of the most bloodthirsty in the entire Bible" (cf. Ps. 137:9), nor Steinzaltz's other statements about Deborah in: A. Steinzaltz, Nashim ba-Mikra3 (Tel-Aviv, 1988), p. 50 (Hebrew). 
representative passages of biblical prose and poetry, the later-day scholar would risk drawing quite inaccurate conclusions as to the nature of ancient society. The story gives the impression that women were judges and military leaders in war. The woman instigates the war and the men obey her commands. The prophetess denounces or curses the men who evade battle, and praises the bravery of a woman for achieving the final victory. ${ }^{9}$ The women are elated at the victory, and they grieve over the fallen; the men seemingly take no part in these actions.

The victory hymns of Miriam and of Deborah are alike in that both praise the glory of God after the war. However, while Miriam sings with "all the women," Deborah's hymn lacks any social context. It is not clear whether the hymn of praise was recited before men or women or perhaps, like Miriam, Deborah sang for the women while Barak sang for the men. ${ }^{10}$

\section{Hannah}

Two prayers said by Hannah, mother of the prophet Samuel, are included in the Bible. 1 Sam. tells of the pilgrimage made by Elkanah and his two wives, Hannah and Peninah, to sacrifice at the tabernacle in Shiloh. Peninah angered Hannah by referring to her barrenness, ${ }^{11}$ and Hannah turned to God for solace:

In her wretchedness she prayed to the Lord, weeping all the while. And she made this vow:

O Lord of Hosts, if You will look upon the suffering of Your maidservant and will remember me and not forget Your maidservant, and if You will grant Your maidservant a male child, I will dedicate him to the Lord for all the days of his life; and no razor shall ever touch his head. (I Sam. 1;10-11).

Following this appeal, the next verse reads: "As she kept on praying before the Lord, Eli watched her mouth." The embittered Hannah was wholly absorbed in crying and praying; she addressed God by two

9 The role of distributing blessings and curses in the name of God was usually reserved for the priests or levites. See, for instance: Deut. 27:9 ff.

10 A meticulous comparison between the opening passages of the song of Moses and of the song of Deborah will show that, just as the people responded to the song sung by Moses, Barak responded to Deborah's song. However, this form of song, by a man and woman singing individually by turns, is not known in antiquity, and was denounced in $b$. Sotah 48a: "R. Joseph said: when men sing and women join in it is licentiousness; when women sing and men join in it is like fire in tow."

11 Other barren women in the Bible are Sara, Rebekah and Rachel. The mothers of the great men needed God's intervention in order to have children. With the exception of Rebekah, the Bible emphasizes that the woman was sterile, not the man, as the man had children with a different wife. 
different titles, emphasizing her point so that he would not forget her. She stressed that she was but a servant of God (features recalling the "Remembrance" (Zikhronot), of later composition and of a communal, not personal nature.) $)^{12}$ Hannah requested a son, and, as if to persuade God to relent, she promised Him her son after his birth. This prayer can be classed as a well-worded appeal for help from a supplicant with a personal, eminently feminine problem. ${ }^{13}$

Hannah's other prayer appears in 1 Sam. 1: after God granted her wish, she fulfilled her oath to bring her son to the tabernacle. This prayer is couched in the elevated style of other biblical hymns, but a close reading shows that its words and ideas are not essentially those of a barren woman:

I gloat over my enemies... The bows of the mighty are broken, and the faltering are girded with strength... For not by strength shall man prevail. The foes of the Lord shall be shattered... The Lord will judge the ends of the earth. He will give power to His king, and triumph to his anointed one.

These words constitute a hymn of praise to God spoken by one who set out to war in the name of God and returned home safely. The person praying recognizes that the war is waged by God, as in the hymn of Deborah. This hymn also resembles the victory songs of Moses and David, though the present hymn surpasses that by Moses: Moses refers to the temple, whereas the present hymn refers to the king of Israel; the warriors request that God strengthen the leaders, the anointed king and the high priest. ${ }^{14}$

12 On the similarity between the prayer said by Hannah and the Rosh Hashana prayers, see further below. The story of Hannah is the Haftarah portion read on Rosh Hashana. Attention should also be called to the prepositions in Hannah's prayer: to God, before God. See Y. Jakobson, Hazon Hamikra,2 (Tel-Aviv, 1963), pp. 354-356 (Hebrew, in the chapter on mothers in the Bible). If the interpretation that considers the formula "to God" as a sort of plaint is correct, then it is understood why one of the prayers that the rabbis attributed to Hannah bears the mark of a legal accusation. See below.

13 See: R. Alter, The Art of Biblical Narrative (Basic Books, Inc., New York, 1981), p. 84. Alter believes "it is just the sort of prayer that a simple, sincere country wife, desperate in her barrennes, would utter." However, this definition is inexact even by Alter's own definition of the characteristics of prayer. See below for additional examples of prayers by "simple" women.

14 The song most resembling Hannah's song is in 2 Sam. 22 (=Ps. 18): "David addressed the words of this song to the Lord after the Lord had saved him from the hands of all his enemies ... O God, the rock wherein I take shelter, my shield ... my fortress and refuge! The Lord thundered forth from heaven... He rescued me from my enemy so strong... For I have not been guilty before my God...With the blameless hero, blamelessly.... Who trained my hands for battle, So that my arms can bend a bow of bronze!... Tower of victory to His king, Who deals graciously with His anointed", etc. 
A close reading of the two prayers ascribed to Hannah shows that the two prayers were not by the same person. The second prayer was apparently attributed to Hannah due to the words "the barren woman bears seven," though these words do not in fact justify the attribution of the prayer to Hannah (who until then had given birth only to Samuel, and in any case, it is a literary expression, similar to the one in Ruth 4:15; Jer. 15:9). Attributing prayers to famous characters, whether man or woman, is well attested in biblical literature, the apocrypha and talmudic literature. The historiographical tendency to ascribe a prayer that "might have been said at the time" to a certain figure was not the work of a later redactor, but a guiding principle in ancient literature (see also Is. 38:9-20; Jonah 2:2-10). ${ }^{15}$

Even if the biblical text is taken at face value and the prayer (recited as part of the Sephardi daily prayers) attributed to Hannah, we are still left with a very small number of biblical prayers by women, a situation rectified in all branches of post-biblical literature.

\section{Post-biblical literature}

The apocrypha is replete with prayers. In many cases the author gratuitously adds a prayer to the words of a biblical character. However, this is not unique to the apocrypha and occurs throughout post-biblical literature, including rabbinic literature. For this reason, and for our present purpose, the prayers will be analyzed here according to biblical chronology: instead of discussing the date of composition of each prayer individually, it seems that the best course to pursue is to address all post-biblical literature together as a single category, and arrange the prayers according to the chronological appearance of the biblical characters. Hence, Eve's prayer will be cited first, followed by those of other biblical women, and finally the prayers of women from the apocrypha who do not appear in the Bible will be studied. ${ }^{16}$

Compare these verses to the song of Moses, though we will not discuss this at present. See: M. Zeidel, Tefillat Hannah vehashpa'atah", Sinai, VI (1940), pp. 437-451 (Hebrew); N. Klaus, Iyyunim ba-sipur ha-Mikrai (Tel-Aviv, 1990), pp. 118-121 (Hebrew). The appearance of identical phrases and ideas indicate that here are two paeans of victory and thanksgiving to God, and not a prayer said by a woman thanking God for the fulfillment of her personal request for a son. It is nonetheless possible that the prayer was attributed to Hannah because it was sung by women, like other songs of victory, for example, I Sam. 18:6 (see ch. 3).

15 See also: Leila Leah Bronner, From Eve to Esther: Rabbinic Reconstructions of Biblical Women (Westminster John Knox Press, Louisville, Kentucky, 1994), pp. 87-98 (and see below).

16 See the following studies on prayers in the apocrypha: Sidney S. Tedesche, "Prayers 


\section{Eve}

The Talmud, in b. Abodah Zarah 8a tells of Adam, who, upon seeing the first sunset, said:

"Alas, it is because I have sinned that the world around me is becoming dark... so he sat up all night fasting and weeping and Eve was weeping opposite him." On the first Sabbath, then, Adam and Eve prayed and wept together, asking God for forgiveness for their $\sin .{ }^{17}$ (tr. under the editorship of I. Epstein, London: Soncino, 1988)

Another talmudic version of this story appears in the apocryphal Life of Adam and Eve 32:

Then Eve rose and went out and fell on the ground and said:

"I have sinned, O God, I have sinned, O Father of all, I have sinned against the cherubim, I have sinned against your steadfast throne, I have sinned, Lord I have sinned much, I have sinned before you, and all sin in creation has come about through me." 18 While Eve was still on her knees praying, behold, the angel of mankind came to her... (in: Charlesworth, II, p. 287)

Eve repents, thus redeeming the tarnished image of the biblical Eve. The later sources, then, are not content with depicting Eve as the mother of all life, or as a woman leading her husband astray. For them, Eve is a pious woman who prays to God and repents of her sins. The important difference between the two talmudic and apocryphal sources is that the Talmud regards Eve's prayer as the counterpart of her husband's prayer; while in the apocrypha she prays independently (though at the request of her husband). Moreover, talmudic literature does not quote a verbatim account of Eve's words as the apocrypha does, along with mention of the angel that was revealed to Eve. At the same time, the two traditions are united in speaking of Eve's weeping and repentance (like the tearful Hannah).

of the Apocrypha and their importance in the Study of Jewish Liturgy", Yearbook: Central Conference of American Rabbis, 26 (1916), pp. 376-398; Norman B. Johnson, Prayer in the Apocrypha and Pseudepigrapha (Philadelphia 1948); D. Flusser, "Psalms, Hymns and Prayers", Michael E. Stone (ed.), Jewish Writings of the Second Temple Period, Compendia Rerum Iudaicarum ad Novum Testamentum, section II, (Van Gorcum, AssenFortress Press, Philadelphia, 1984), pp. 551-577.

17 The variants differ as to the word "fast", and the word does not appear in the MS Abodah Zarah in The Jewish Theological Seminary, New York, facsimile S. Abramson (New York, 1957), p. 14, and see below. At the same time, the parallel tradition says of Adam: "He sat and fasted eight days [in prayer]" and the word "prayer" is missing in the MS. It seems, then, that the scribes merged the two traditions into a single text.

18 On the mention of angels in the prayer of a sinner who weeps while praying, cf. further below, ch. 6, to the prayer of Elazar b. Dardoyah. Notice the proliferation of the words "I sinned", similar to the traditional confession prayer of the sinner: "For the sin that I have sinned before You...". 


\section{Rebekah}

It will be recalled that at first Rebekah was barren: "Isaac pleaded with the Lord on behalf of his wife, because she was barren; and the Lord responded to his plea." This is explicated in Midrash Genesis Rabbah 63:5:

Lenokhah (for) his wife - this teaches that Isaac prostrated himself in one spot and she in another [opposite him], and he prayed to God: 'Sovereign of the Universe! May all the children which Thou wilt grant me be from this righteous woman.' She too prayed likewise" (tr. under the editorship of H. Freedman and M. Simon, London: Soncino, 1939, p. 558).

The midrash describes Rebekah praying "opposite" her husband, like Eve and Adam. Rebekah's prayer is not quoted verbatim, though it would seem to have followed along the lines of her husband's prayer. This succinct prayer said by a barren woman differs from Hannah's prayer. It is a reminder that Isaac was the only patriarch to take only one wife, and the only one who prayed to God for a personal problem, and was answered. At the same time, it seems that the original midrashic context of this prayer was the suggestion that Isaac and Rebekah separate and marry other spouses, in the hope that they would have children. In that story, Isaac and Rebekah replied that they wanted to continue living as man and wife. Each spoke of the righteousness of the other, hoping it would act in their favor in their efforts to produce offspring.

Another prayer by Rebekah, in Midrash Ha-gadol to Gen. (ed. M. Margaliot, p. 522), reads: "Master of the Universe, May you make right my humiliation and plead my case and show that I am innocent." This prayer by a barren woman belongs to the genre of a complaint lodged against God. The barren woman implores Him to give her a just hearing, in keeping with the ancient belief that barrenness was a punishment. The barren woman is certain that she did not do any wrong, and should not be punished. She asks God for a just hearing, as she is sure she will be found innocent. This is in the same spirit as other prayers, based on the ancient customs dictating the behavior of a defendant in a court of law. ${ }^{19}$ The accused, Rebekah, hopes to prove her innocence before God as judge, so that God will then reward her with children, and she will no longer suffer humiliation (such as Peninah inflicted upon Hannah). ${ }^{20}$

19 See: J. Heinemann, Prayer in the Talmud: Forms and Patterns (Walter de Gruyter, Berlin - New York, 1977), p. 193 ff. Cf. similar wordings: Ps. 7:9; 26:1; 35:24; 43:1: "Vindicate me, O God, and champion my cause".

20 The pseudo-Jonathan translation to Gen. 25:22 has it that Rebekah went to Shem's academy "to ask God for mercy". 
Here are two prayers by barren women. In neither one is there any hint of a personal or feminine mark, though this is not to say that all barren women necessarily prayed in the same manner.

Jubilees 25:1 ff. tells how Rebekah called Jacob and instructed him not to marry a Canaanite woman. Jacob promised to obey. Rebekah then raised her hands to heaven, spreading her fingers ${ }^{21}$ and prayed:

May the Lord God be blessed, and may His holy name be blessed for ever and ever, He who gave to me Jacob, a pure son and a holy seed; because he is Yours and his seed will belong to You for all times and in all generations forever. $\mathrm{O}$ Lord, bless him and place in my mouth a righteous blessing so that I might bless him (Charlesworth, vol. II, p. 105).

The author attributed a prayer of thanksgiving to the matriarch Rebekah at the birth of her son (though he was 63 at the time!), a prayer reminiscent of Hannah's request for a son. The author was not content with presenting the mother's prayer - he includes also her blessing for her son. The later author, then, adds the mother's prayer to the father's blessing of his son that appears in the Bible, as balance and complement to the biblical text.

\section{Rachel}

Rachel, too, was barren at first. No prayer of hers is mentioned in the Bible, though we read: "Now God remembered Rachel" (Gen. 30:22), employing the same root z-kh-r (to remember) that figured in Hannah's prayer for a son. Indeed, the pseudo-Jonathan translation of Genesis (Gen. 30:6, 8,22 and elsewhere) understands the text as saying that Rachel prayed to God. The barren Rachel, then, prayed for a son, and even though her prayer, unlike Hannah's, does not appear verbatim in the Bible, the post-biblical sources complete the picture by attributing a prayer to her. Sefer Hayashar, a later composition, quotes Rachel's prayer:

Lord God, remember me and give me a child, as my husband will banish me if I do not bear him sons.

Now, Lord God, hear my appeal to you, see my distress and give me sons even as one of the maidservant, so I may be humiliated no longer. ${ }^{22}$

21 See Randall D. Chesnutt, "Revelatory Experiences Attributed to Biblical Women in Early Jewish Literature," Amy-Jill Levine (ed.), "Women Like This": New Perspectives on Jewish Women in the Greco-Roman World (Scholars Press, Atlanta, Georgia, 1991), pp.107-125. Regarding Rebekah's gesture of spreading her fingers, see; G. Alon, Mehkarim betoldot Israel, I, Kibbutz Hameuhad (Tel-Aviv, 1967), p. 181 ff. (Hebrew); H. Jacobson, "The Position of the Fingers During the Priestly Blessing", RevQ, 9 (1977), pp. 259-260.

22 E. Goldschmidt (ed.), Sefer Hayashar (Berlin, 1923), p. 101. On the date of this work, 
As in Hannah's prayer, God is addressed here by two different titles. Additional similarities are the request to be remembered and in the selfportrayal as a simple maidservant. At the same time, Rachel fears that her husband will banish her because she bore no sons, and her fear is her incentive for asking God to consider her plight. This, then, is an eminently feminine prayer.

God does heed this prayer of Rachel's, as we know, and other prayers were also attributed to her. One tradition has it that Rachel prayed that her sister Leah's baby would change from a boy to a girl, and thus Dinah was in actual fact born a boy and not a girl (see next section). However, the most important tradition is of Rachel, the compassionate mother, praying for her sons: "Wailing, bitter weeping - Rachel weeping for her children. She refuses to be comforted for her children, who are gone" (Jer. 31:15). The barren Rachel who prayed for sons was later transformed into Rachel, the bereaved mother, weeping (like other mothers, that is, praying, over her lost children). ${ }^{23}$

\section{Leah}

Leah, Rachel's sister, also prayed to God: "God heeded Leah" (Gen. $30: 17)$ and this appears as well in the pseudo-Jonathan translation of Gen. 30:17, 21. According to one tradition, Dinah should have been born a boy, but the prayer of one of the matriarchs succeeded in effecting the change. One tradition has Leah responsible for the change of the baby's sex, another attributes it to Rachel. ${ }^{24}$ The Bible attributes the naming of the sons to the matriarchs, not the patriarchs, so it is likely that the mother should pray for the desired sex of the child (women usually, it is commonly believed, prefer a son to a daughter). As a rule, only the patriarchs pray in the Bible, not the matriarchs; post-biblical literature, however, rounds out and complements the female biblical characters by including women's prayers that were answered.

see Y. Dan, Ha-sipur ha-ivri bimei ha-beinayyim (Jerusalem, 1974), p. 137 ff. (Hebrew); A. Rosenthal, "Hidat hadpasato shel Sefer Hayashar", Sinai, 79 (1976), pp. 275-288 (Hebrew).

23 On the prayers of the bereaved matriarch Rachel, see Gen. Rabbah 62, 10: "to ask for mercy for them"; the beginning of Lamentations Rabbati 24.

24 Regarding Leah, see: pseudo-Jonathan to Gen. 30:21; b. Berakhot 60a, which calculates the time during pregnancy when one can ask for mercy for the unborn infant. Regarding Rachel: See y. Berakhot 6:5, 14a: "Since Rachel prayed, it [the infant] was made a girl." 


\section{Tamar, daughter-in-law of Judah}

In the pseudo-Jonathan translation to Gen. 38:25, we read of Tamar's prayer to God after Judah had pronounced that she be burned at the stake:

She raised her eyes heavenwards and said: Please, God, in your mercy, respond to my distress and open my eyes so that I may find three witnesses (a seal, a cord and a staff, all belonging to Judah) and I will bear you three martyrs (Hannaniah, Mishael and Azariah) who will sanctify your name and enter the burning oven in the Valley of Durah. ${ }^{25}$

The underlying reasoning of Tamar's prayer is similar to that of Hannah's: give me a son now, and I will come to your rescue later on, through my son. ${ }^{26}$

\section{Aseneth}

One of the difficulties faced by the authors of the midrash was to explain how it was possible that Joseph the Righteous married Aseneth, daughter of Poti-phera the priest of On (Gen. 41:45). Several interpretations have been offered, one suggesting that Aseneth converted to Judaism. This chain of events does not appear in the Bible and is unknown in rabbinic literature, but it does appear in the apocrypha. In the apocryphal Joseph and Aseneth, we learn that Aseneth converted, and when she became aware of the existence of the Creator of the Universe, she did the following:

And she took a piece of sackcloth and girded it around her waist. And she loosened the clasp of the hair of her head and sprinkled ashes upon her head. And she scattered the ashes on the floor with both hands, and wept bitterly, and fell upon the ashes and wept with great and bitter weeping all night, with sighing and screaming until daybreak (Charlseworth, II, p. 216). ${ }^{27}$

Aseneth underwent physical mortification after the fashion of mourners and sinners, and shed tears all night long, like Eve. She fasted for seven days, raised her hands eastwards and her eyes heavenward and prayed:

Lord God of the ages, who created all things and gave life to them, who brought the invisible things out into the light, ... to you I will shout, Lord, to you I will pour out my supplication, to you I will confess my sins, and to you I will reveal my lawless deeds.

25 In D. Rieder, Targum Yonatan ben Uziel al ha-Torah (Jerusalem, 1974), p. 60.

26 A. Shinan, Aggadatam shel Meturgemanim (Jerusalem, 1979), p. 327 ff. (Hebrew).

27 Cf. the composition known as "The prayer of Manasseh", a prayer said by a newlyobservant Jew: Charlseworth, II, pp. 625 ff. 
Spare me, Lord, because I have sinned much before you, I have committed lawlessness and irreverence, and have said wicked and unspeakable things before you ...I have sinned, ...I, Aseneth, daughter of Pentephres the priest, the virgin and queen, who was once proud and arrogant.... Rescue me before I am caught by my persecutors, For just as a little child who is afraid flees to his father... And the lion their father furiously persecutes me, but you, Lord, rescue me from his hands... Rescue me, Lord, the desolate and solitary, because my father and my mother disowned me and ...Behold, I put off my linen royal robe, interwoven with violet and gold, and dressed in a black mourning tunic. Behold, I loosened my golden girdle and threw it off me and girded a rope and sackcloth around myself...and have sprinkled ashes (upon my head) (Charlesworth, II, pp. 220-223).

Then an angel is revealed to Aseneth, announcing that God has heard her prayer. She is instructed to change her clothes of mourning. Upon his orders, the convert removes the scarf from her head, and the angel of God announces once more that God has heard her prayer and her name will be inscribed in the Book of Life. We have, then, a description of the conversion of a gentile woman who prays to God asking his forgiveness, like Eve before her, and God accepts her prayer and sends her an angel. ${ }^{28}$ It should be noted that Aseneth, like Deborah, refers to herself by name in her prayer. The mention of motherhood and the feminine items of clothing add a feminine imprint to this plea for forgiveness.

\section{The wife of On, son of Peleth}

On, the son of Peleth, was at first a member of the rebellious company of Korah (Num 16:1) but his name subsequently disappears from the text. The midrash explains this by saying that he distanced himself from the conflict, or, rather, his wife saved him from sinning by dissuading him from taking part in the rebellion. The authors of the midrash highly praised On's wife for saving her husband. They relate that when the earth yawned open to swallow Korah and his company, On's wife seized a staff and said:

Lord of All Worlds,

He has already sworn in Your great Name that he would never take part in a rebellion. As Your Name, God, is endless and lasts forever - thus will You be able to exact his punishment, if ever he transgresses his vow. ${ }^{29}$

28 Compare to the conversion of the prostitute from the Cities of the Sea (below, ch. 6). Both cases feature beautiful gentile women who talk of their gods, sleep on golden beds, fall in love with a Jew of Eretz-Israel, distribute money generously to charity, convert to Judaism and marry their beloved. Various parallels to this composition are found in the early midrashei aggada, and for this reason, strands related to Jews and to Eretz-Israel are embedded in it, though it may have originated in Alexandria.

29 According to Midrash Ha-Gadol on Num 16:32, ed. by Z.M. Rabinowitz (Jerusalem, 
This righteous woman first saved her husband from sinning, and then she prayed to God to rescue her husband from the gaping earth, saying her husband had previously sworn never to participate in a rebellion. Even if this is not a feminine prayer per se, it would seem that a woman pleading for her husband's life is definitely a feminine matter.

\section{Jael}

Jael, a minor figure in the war against Sisera, won elaborate praise in the hymn of Deborah. However, the later traditions were not content with Deborah's praise and added further details to the biblical account. Pseudo-Philo 31 recounts that Jael was a beautiful woman. Sisera fled to her and she adorned herself with jewels and approached him. ${ }^{30}$ Sisera requested milk, and while he was sleeping, Jael went out to the flock and got milk.

And when she was milking she said: "And now be mindful, O Lord, of what you assigned every tribe or race to the earth. Did you not choose Israel alone and liken it to no animal except to the ram that goes before and leads the flock? And so look and see that Sisera has made a plan and said, 'I will go and punish the flock of the Most Powerful One,' and I will take from the milk of these animals to which you have likened your people, and I will go and give him to drink. And when he will have drunk he will be off guard, and afterward I will kill him. But this will be the sign that you act along with me, Lord, that, when I enter when Sisera is asleep, he will rise up and ask me again and again, saying, 'Give me water to drink,' then I know that my prayer will have been heard (Charlesworth, II, p. 344).

Jael's prayer raises several points of interest. First, it must be noted that it takes place at the hour of milking, showing a countrywoman whose metaphors draw upon the daily reality of her life. ${ }^{31}$ Jael appeal to God with a request for him to "remember" (reminiscent both of Hannah's prayer and the "Remembrance" prayer for the New Year) and goes on to note Israel's chosen status in her prayer for salvation. ${ }^{32}$ The author whether man or woman - says that Jael requested God to give her a sign, like the sign requested by the servant of Abraham. This is, then, a form of prayer characteristic of non-Jews living in a Jewish environ-

1978), p. 278. Cf. b. Sanhedrin 109b, where the story appears in a similar version but with the omission of the woman's prayer.

30 In: Charlesworth, II., pp. 297 ff. See more about Jael above, ch. 1.

31 Cf. Hannah's prayer, described by a modern scholar (above, n. 13) as the prayer of a simple woman, and cf. the prayer said by the wife of Obadiah, below.

32 Cf. additional prayers for salvation that make mention of Israel's chosen status, in M. Bar-Ilan, "Ra'ayon ha-behira ba-tefillah ha-yehudit", S. Almog and M. Heyd (eds.), Ra`ayon ha-behira be-Yisrael u-va`amim (Zalman Shazar Center for Jewish History, Jerusalem, 1991), pp. 121-145 (Hebrew). 
ment. Later, before Jael deals Sisera the fatal blow, she again turns to God in prayer and says: "Strengthen me today, Lord, on account of You and Your people and those who hope in You" (Charlesworth, II, p. 345).

The motif of Jael's conversion to Judaism differs in rabbinic traditions and in the apocrypha: in the apocrypha, Jael is the ultimate heroine - she is beautiful and she prays to God, too. The post-biblical tradition is not content to portray the valiant Jael as the gentile wife of Heber the Kenite. This is the motivation behind the story of her conversion, and the specific mention of Israel as the chosen people in her personal prayer.

\section{Mother of Samson}

Judges 13:2-5 tells us that the wife of Manoah was barren. An angel came to her and announced the birth of her son, Samson. This biblical story was elaborated in Pseudo-Philo's account: we learn that the wife's name was Eluma, daughter of Remac, and that her husband Manoah asked her permission to take another wife so that he would not die without a son. The couple argued and were saddened that they had no son, until Eluma went up on the roof of her house one night and prayed:

Behold you, Lord God of all flesh, reveal to me whether it has not been granted to my husband or to me to produce children, or to whom it may be forbidden or to whom it may be allowed to bear fruit in order that whoever is forbidden may weep over his sins because he remains without fruit. Or if both of us have been deprived, then reveal this to us also so that we might bear our sins and be silent before you (Charlesworth, II, p. 355).

After this prayer, God sent the angel to Eluma again, and He announced that she, and not her husband, was barren. He added that God had heard her entreaty and would grant her a child. The author of Pseudo-Philo, then - whether man or woman - linked the angel's revelation to the woman, in itself a rare event in the Bible, to her prayer, and added, almost incidentally, "feminine" details unknown from other sources: a husband wishing to take a second wife but first requesting his wife's permission (and the argument between the couple). The prayer said by Samson's mother is of especial interest. In the biblical account, husbands of barren woman (Sara, Rachel, Hannah) had other wives and had sons from them, so it is clear that the wife's barrenness was a punishment for her own sins. But since Samson's father did not have another wife, how is one to know that the barren party was the wife perhaps it was the man who had sinned. For this reason the angel appears and announces that the woman is indeed barren, but God has 
heard her prayer. Clearly here is a feminine expression of the problem of sterility in antiquity. ${ }^{33}$

\section{Hannah}

To Hannah's prayer, as recounted in 1 Sam., post-biblical traditions added other prayers, based on the verse saying that she "kept on praying" (1 Sam. 1:12). In b. Berakhot 31b there is a lengthy discussion about Hannah's unique prayer. Different talmudic sages ascribe different versions of the prayer to Hannah:

(1) Said Hannah before the Holy One, blessed be He: Sovereign of the Universe, of all the hosts and hosts that Thou has created in Thy world, is it so hard in Thy eyes to give me one son?...

(2) Hannah said before the Holy One: Sovereign of the Universe, if Thou wilt look, it is well, and if Thou wilt not look, I will go and shut myself up with someone else in the knowledge of my husband Elkanah, and as I shall have been alone they will make me drink the water of the suspected wife, and Thou canst not falsify Thy law, which says, she shall be cleared and shall conceive seed.

(3) Sovereign of the Universe, Thou hath created in woman three criteria of death [(some say three armor joints of death), namely, niddah, hallah and the kindling of the light on Sabbath] Have I transgressed in any of them?

(4) Sovereign of the Universe, among all the things that Thou hast created in a woman, Thou hast not created one without a purpose, eyes to see, ears to hear, a nose to smell, a mouth to speak, hands to do work, legs to walk with, breasts to give suck. These breasts that Thou hast put on my heart, are they not to give suck? Give me a son, so that I may suckle with them (BT, translated under the editorship of I. Epstein, London: Soncino, 1988).

All three prayers attributed to Hannah by the talmudic sages differ from her biblical prayer. Three of the four prayers are distinctly feminine $(2,3,4)$ : prayers 1 and 4 make explicit requests for a son; in 2, the same request is implied. The prayers are each couched in a different tone: the first is a simple plea, the second aims to compel God to carry out the will of the woman praying to him (somewhat like a magical spell). The third prayer is a complaint lodged against God, like that of the barren Rebekah (with allusions to $\mathrm{m}$. Shabbat 2:6). The fourth prayer is an attempt to persuade God that it is illogical that Hannah has no sons. ${ }^{34}$ All the prayers mention that the barren woman prayed often to God, as is indeed stated in the biblical account. ${ }^{35}$

33 Cf. other feminine literary qualities of Pseudo-Philo, above, ch. 3, n. 29.

34 Heineman (above, n. 19) cited only three out of the four prayers, and considered them one single prayer.

35 Cf. the woman in the apocryphal Vision of Ezra 7:38 who prayed "day and night" because she was barren. 
The following is yet another prayer attributed to Hannah; once more, it is an attempt to persuade God that she deserves a son. ${ }^{36}$ :

Master of the Universe, there is a host above, and there is a host below. The host above do not eat, nor drink, nor procreate, nor die, but they live for ever; and the host below eat, and drink, and procreate, and die. Now I do not know of what host I am, whether I am of the one above or the one below. If I am of the host above, I should not be eating, nor drinking, nor possibly bearing children, nor dying, for I should live for ever, just as the host above live for ever. But if I am of the host below, then not only should I be eating and drinking, but I should be bearing children and eventually dying, even as the host below eat, and drink, and procreate, and die (Pesikta Rabbati, tr. by William Braude, YUP, New Haven and London, 1968, p. 757).37

In conclusion, we see that many prayers were attributed to Hannah, and the authors of the midrash regarded her as the exemplary model of a woman praying to God. ${ }^{38}$

\section{Tamar, daughter of David}

The date of the composition of the apocryphal The Words of Gad the Seer is uncertain. ${ }^{39}$ The book deals chiefly with Gad, David's seer, but refers to other events as well. It tells of Tamar, David's daughter, who fled to Geshur after being raped by her half-brother, Amnon. There she again fell victim to an attempted rape. The biblical account tells only of Tamar's rape by Amnon, while in the apocryphal account she prays to

36 Compare this prayer to the ancient liturgical poem composed in Eretz-Israel, recited as part of the Rosh Hashana service: 'Today is the birthday of the world... if as children... if as servants'.

37 The words of R. Judah b. R. Simon in Pesikta Rabbati 43. The same rabbi also cites two other prayers which in $b$. Berakhot $31 \mathrm{~b}$ are attributed to other sages (and then he cites an additional prayer), closely resembling prayer no. 3 in Berakhot.

38 In the discussion in $b$. Berakhot $31 a-b$, several halakhot are inferred from Hannah's prayer, such as: "from this we learn that one who prays must direct his heart"; "from this, that a drunken person is forbidden to say the Tefillah"; "From this we learn that it is forbidden to sit within four cubits of one saying Tefillah", etc. Pesikta Rabbati 40 has: "the requirement of nine benedictions in the Tefillah for the New Year's Day may manifestly be inferred from the chapter with Hannah's prayer" (which is the Haftarah portion for New Year's Day. See: b. Megillah 31a; b. Rosh Hashana 11a). Midrash Samuel 5 has the following saying in the name of Rabbi Judah: "Korah and his community kept sinking lower and lower, until Hannah appeared and prayed for them." That is, Hannah had power even over those who had long since descended to hell in the bowels of the earth. Cf. also the prayer that Hannah said for the sons of Peninah. In Pesiktah Rabbati 43, p. 767: "be forbearing toward her in regard to her two children and let them stay alive." In Yalkut Shimoni on 1 Sam, 80: "Hannah prayed - from this we learned that women are obligated to pray, since Hannah prayed the eighteen benedictions."

39 Cf. ch. 1, above, regarding the plot itself, as well as the bibliographical details. 
God, upon which she is immediately rescued from her second assailant. Thus does Tamar pray:

Tamar took up the harp to play pleasant tunes and said to herself:

God of David, your servant and my father:

send your light and your might to uphold me and do not permit the lust of the evil and unclean uncircumsized; You know what is in my heart - do not allow the daughter of your servant David to be violated;

my father David, my father David, my father David!

see the shame and disgrace of your daughter; Go, approach God's Divine throne and beg mercy for me from God Almighty to come to my rescue;

He does not want evil done by cruel men....

O God, save me! O God, be victorious!

I will call out to you when I fear and you will reply, and do not waste holy seed by uncleanliness;

since you are the holy God and I trust in you.

Tamar, then, prays in her heart out of fear of her assailant, accompanied by a kinnor (as in the temple service), and in fact says two prayers: one addressed directly to God, and the other to David, her father, asking him to pray before the throne of God on her behalf. ${ }^{40}$ She includes biblical verses in her prayer, and God indeed heeds her. When the assailant falls asleep, Tamar takes his sword from its scabbard and says:

God Almighty, Remember David, and give me of his strength and Your might to sustain me; Help me, as you helped the wife of Heber the Kenite to abolish evil and evil-doers from the land, So all will know that You alone are God.

Tamar addresses God (the text reads: Yahweh) and, like Hannah, requests that God remember the merit of the patriarchs (like the "Remembrance" prayer) and asks God for assistance, as he assisted Jael. And indeed, after she has killed her assailant, she says aloud:

Thus do perish all Your enemies and the enemies of Your people, God;

I have now seen that You have heeded my father and have not abandoned his daughter to the disgrace of evil men;

Blessed are Thou forever and ever, Amen.

Tamar's last prayer ends with a reworking of Deborah's prayer (Judg. 5:31), and her concluding words paraphrase the conclusion of the Book of Psalms (Ps. 99:53). It may be said that the prayers of Tamar, daughter of David, are unique, and merit further study, as does The Words of Gad the Seer as a whole. ${ }^{41}$

40 For the mention of the Chariot in the prayer service, see M. Bar-Ilan, "Birkat 'Yotzer Ha`adam' - mekomot hofa'ata, tifkuda umashmauta”, HUCA, 56 (1985), Hebrew section, pp. 8-27.

41 I propose to deal elsewhere with the prayers in The Words of Gad the Seer in 


\section{The wife of the prophet Obadiah}

The post-biblical authors of the midrash identified the prophet Obadiah with "Obadiah, the steward of the palace" (1 Chron. 18:3), the most senior official in King Ahab's court. The verse goes on to say that Obadiah "revered the Lord greatly" and provided the prophets of God with food, drink and shelter when they were persecuted by Jezebel. The authors of the midrash inferred from this that the two were one and the same. This, in turn, led them to identify the woman referred to in the verse "A certain woman, the wife of one of the disciples of the prophets" (2 Kings 4:1), as Obadiah's wife. This woman brings her case to Elisha, saying that a creditor is about to seize her two children, and Elisha performs a miracle with a jug of oil and saves her. The reasoning behind this identification was, apparently, to redeem Obadiah from obscurity. This is a well-known device in the midrash (the prophet's father's name is not mentioned) and to reward Obadiah. Just as Obadiah gave the prophets of God food and drink, the prophet Elisha extends aid to Obadiah's wife in her hour of need. It thus transpires that God gives assistance to the woman thanks to the righteousness of her husband, not for any merit of her own. In a later midrash, Obadiah's wife is praised over all women, and her husband's righteousness in providing food and drink for the prophets is attributed to her. The compilers of the midrash believed that when God created Eve, he saw that women were destined to "lead his sons astray"; however, the thought of Obadiah's righteous wife counterbalanced the future evil and justified the creation of Eve: "If I create Eve who is called "one" (Gen. 2:21), not for one alone, I am satisfied." 42 Following this opening there are several formulas of prayer by the same woman:

(1) Master of the Universe,

I know that there is no forgetfulness before your Throne.

A man plants squash: he takes the large ones to sell, and takes pity on the small ones and sleeps on them; at night he goes to water them.

greater detail.

42 "Midrash be-isha ahat mi-neshey bnei ha-neviim", Magazin, 3 (1876), 153 (=J.D. Eisenstein, Ozar Midrashim, I, rep. Jerusalem 1969, pp. 144-145; on the fragments of the midrash found in the The Lost Midrash to Ruth); L Ginzberg, Ginzei Schechter, I (New York, 1927), pp. 298-299 (Hebrew); L. Ginzberg, Legends of the Jews, VI. CF also Midrash Ha-Gadol to Ex. 30:12: "Israel would have been destroyed were it not for the merit of Obadiah's wife." A similar wording is found in Pesikta de-Ra Kahana, tr. William Braude and Israel Kapstein (JPS, Philadelphia, 1975), p. 28: "Israel would have been destroyed in that hour of God's wrath were it not for the merit of Obadiah's wife."

The authors of the midrash transferred Obadiah's charity to his wife, apparently because it is usually women who feed the hungry (see further below). 
You do not forget the squash, yet You forget the wives of the sons of the prophets?

Also, she said before Him:

(2) Master of the Universe,

In the heavens are the signs Pleiades and Orion. When the Flood descended upon the world, Pleiades stole two stars from Orion, and You will comfort it in the future, as it is written: (Job 38:32): "Can you... conduct the Bear with her sons?"

You forget not to return them, yet You forget the wives of the sons of the prophets?

Also, she said before Him:

(3) Master of the Universe,

I know that You are merciful and support no cruelty, as it is written (Ps. 116:9):

"(He) who gives the beasts their food, to the raven's brood what they cry for."

You forget them not, yet you forget the wives of the sons of the prophets?

She said before Him:

(4) Master of the Universe,

My husband lends to You alone, who lend and demand payment honestly, as it is written (Prov. 19:17): "He who is generous to the poor makes a loan to the Lord." And your servant, my husband is dead!

She said before Him:

(5) Master of the Universe,

If a woman's father and mother die she depends on her husband. If her husband dies, whom can she depend on?

If she be wealthy - people assist her according to her wealth. And who takes a widow and her two sons into his house?

After the widow says these prayers, she goes to the cemetery and calls to her husband to rescue her: "She gathered some earth and threw it on her head and from the dirt she called to him: 'my husband, my husband." We see, then, that in addition to the five prayers cited in the midrash, the woman prays at her husband's grave with dust heaped on her head. She then goes with her children to Elisha "in sackcloth," that is, in mourning, and the children beg: "Take us, father, for we have no savior," in other words, they prayed to die. These prayers raise several points of interest. In the first three prayers like Hannah, mother of Samuel, the woman appeals to God not to forget her. ${ }^{43}$ Moreover, the mention of God's throne as an expression of respect, is a metonymic substitution for the name of God himself, familiar from the prayers of Eve and Tamar, daughter of David, and the "Remembrance" prayer: individual and communal prayers converge here. ${ }^{44}$

The widow employs an interesting and unfamiliar form of address. The image of squash indicates that she is a countrywoman, and details

43 Cf. the prayer said by the people of Israel to God, according to Resh Lakish (b. Berakhot $32 \mathrm{~b}$ ). This is a feminine prayer said by a woman when her husband takes a second wife.

44 See M. Bar-Ilan, Sitrei Tefillah ve-Hekhalot (Ramat-Gan 1987, Hebrew), under zikhronot in the general index. 
of her daily life are integrated into her prayer, similar to Jael, who prays in the very act of milking the goat; in that same context, the ram another image from nature - symbolizes Israel. The image of Pleiades and Orion makes use of a popular legend (based on an alternative reading of תנחם, one that differs from the accepted vocalization) which appears in b. Berakhot 58b-59a: What is meant by Kimah (Pleiades)? ... What is meant by 'Ash (the Bear)...'Ayish will be comforted for her children... she is saying to her, give me my children.. ${ }^{45}$ The woman (or the midrash that attributes the prayer to her) was familiar with the aggadah that mentions consolation for the mother whose two children were taken from her, in a situation similar to that of Obadiah's wife, and she included the legend in her prayer. In this way, composers of liturgical poetry drew upon rabbinic aggadah and wove them into their work. One of Hannah's prayers, too, alludes to Mishnah Shabbat. Three of the five prayers conclude with a biblical verse, after the traditional format of prayers. Femininity appears explicitly only in the fifth prayer, and perhaps in the second prayer as well. This prayer belongs to the genre of remonstration against God: the woman sets forth her case before God, like a defendant in court (cf. the prayers of Rebekah and Hannah, above), calling upon God to come to her assistance. All the prayers by women were uttered in their hour of need, when they were alone, and presumably reflect familiar prayers - not necessarily said by woman.

\section{Esther}

In the biblical Book of Esther, God's name is not mentioned once. Esther's moral and religious standards too leave much to be desired. This lack was rectified in the apocryphal Additions to Esther, which paints Esther in a more religious light, with the intent of improving her image so that the wife of a gentile king can assume a place of honor in the Jewish community. ${ }^{46}$ According to this addition, Mordechai prayed for the rescue of the Jewish people, and afterwards Queen Esther recited the following prayer:

My Lord, our King, Thou art God alone; help me who stand alone, and have no helper save Thee: for my danger is in my hand.

45 See: N.H. Tur-Sinai, Sefer Iyyov (Tel-Aviv, 1954), pp. 95-98; C. Milikowsky, "Kima and the Flood in Seder 'Olam and B.T. Rosh Ha-Shana Stellar Time-Reckoning and the Uranography in Rabbinic Literature", Proceedings of the American Academy for Jewish Research, 50 (1983), pp. 105-132.

46 Cf. also the characterization of Esther, above, ch. 1. 
I have heard ever since I was born in the tribe of my family that Thou, Lord, didst take Israel out of all the nations, and our fathers from their progenitors, for an everlasting inheritance, and that Thou didst for them all that Thou didst promise.... But save us by Thy hand, and help me who stand alone, and have none save Thee, $O$ Lord, Knowledge hast Thou... and Thou knowest that I hate the glory of the wicked, and I detest the bed of the uncircumcised and of any alien.... And thy servant hath not eaten at the table of Haman... And Thy servant hath known no joy since the day I was brought until now, save in Thee, Lord God of Abraham. O God, whose strength is over all, hear the voice of the hopeless, and save us from the hand of them that deal wickedly, and save me out of my fear (R.H. Charles, The Apocrypha and Pseudepigrapha of the Old Testament, Oxford 1913, pp. 676-8).

In her prayer for her people, Esther calls upon God to save Israel, His chosen people. ${ }^{47}$ It is clear, therefore, that the mention of the chosen people in a prayer for the rescue of the people of Israel is a vital component of the prayer, as in Jael's prayer and others of a similar nature. Esther also refers to the omniscience of God, a theme that appears too in the "Remembrance" prayer; she emphasizes her status as a mother, a feature of women's prayers which we discussed above. ${ }^{48}$

Of special note is Esther's apologetics: she distances herself from any possible charge that could be leveled against her, charges which indeed surface in a discussion in the Talmud. ${ }^{49}$ In addition, Esther's prayer is known also from rabbinic sources and not from the apocrypha alone: in the former, however, it is precisely those positive arguments in Esther's favor that are missing. ${ }^{50}$ It would seem that at the end of the talmudic period the doubts about the sanctity of the book of Esther had all but dissipated, and the midrash felt no further need to justify Esther, although they did add a gratuitious prayer to the biblical account.

47 See above, n. 32 .

48 The text continues "and upon the third day, when she ceased to pray." That is, the author read Esther 4:16 "and fast for me... for three days," as though the fasting was accompanied by praying. However, the prayers discussed hitherto cannot confirm this, and there is no proof that Esther's fast was accompanied by prayer.

49 B. Sanhedrin 74b: "Esther was merely natural soil" (meaning that it took place against her will, as in Esther 2,8: "Esther too was taken into the king's palace"). Regarding Esther's statement that she never ate at Haman's table, we read in b. Megillah 12a: "R. Simon b. Yohai was asked by his disciples: Why were the enemies of Israel in that generation deserving of extermination. He said to them: Do you answer. They said: Because they partook of the feast of that wicked one". See further ibid. 13a. 50 Cf. Esther's prayer in Esther Rabbah 8 (it is clear there that the author was familiar with the apocryphal Additions to Esther); a second translation of Esther, ch. 5 (a very lengthy prayer of a completely different nature); A. Yellink, Beit Ha-midrash2 (Jerusalem, 1938), V, pp. 5-8. 


\section{Sitis, Job's wife}

The apocryphal Testament of Job preserves several prayers and sayings by women, notably elegies. ${ }^{51}$ The book tells of Sitis, Job's wife, who faced eastwards, fell down and prayed in the following words:

Now I know that I have a memorial with the Lord. So I shall arise and return to the city and nap awhile and then refresh myself before the duties of my servitude (Testament of Job, Charlesworth, p. 860).

Immediately upon concluding this prayer, Sitis falls dead. Obviously this is a deathbed prayer, though this is not stated explicitly. Like Hannah, Sitis requests that God remember her, and asked for a reward in the hereafter, showing that she was certain of being found innocent.

Herea, Job's daughter, sings hymns of the angels to God; the exact nature of these hymns is unknown. Of Job's other daughter, Amaltheia's Horn, it says that she was: "...glorifying the Master of virtues by exhibiting their splendor (cherubim). And finally whoever wishes to grasp a trace of "The Paternal Splendor" will find it written in "The Prayers of Amaltheia's Horn". The author here knows of - or invents - the existence of a compilation of prayers by the woman Amaltheia's Horn, which included, aside from prayers to God, also praise by her father, Job. ${ }^{2}$ It is difficult to know what book of feminine prayers the author was referring to, since a compilation of women's prayers in book-form would be created only over fifteen hundred years after the supposed date of the book of prayers of Amaltheia's Horn.

Following this look at biblical women, or rather, at post-biblical traditions of biblical women, we turn now to the prayers by women in the apocrypha, which would seem to be of later composition than those treated until now.

\section{Judith}

The Book of Judith deals mainly with the bravery of Judith, who saved her city and her people. ${ }^{53}$ The author heaps all possible praise upon Judith, short of calling her a prophetess: she was high-born, obedient, beautiful, wealthy, pious, and most importantly - brave. Chapter 9 in the book is devoted wholly to the prayer of Judith, a woman crying out for help:

51 See, on this matter and on this book in general, above, ch. 3.

52 Cf. the prayer of Tamar daughter of David, who mentions her father in her prayers. See further, below, in the prayer of Judith, and in M. Bar-Ilan, Sitrei Tefillah ve-Hekhalot, p. 125.

53 See above, ch. 1, for more on this matter. 
O Lord God of my father Simeon, into whose hand Thou gavest a sword to take vengeance of the strangers who loosened the girdle of a virgin to defile her, and uncovered the thigh to her shame, and profaned the womb to her reproach.... gavest their wives for prey and their daughters to be captives... O God, O my God, hear me also that I am a widow... and they know not that Thou are the Lord that breaketh the battles, the Lord is Thy name. Dash down their strength in Thy power, and bring down their force in Thy wrath... break down their stateliness by the hand of a woman...Yea yea, God of my father and God of the inheritance of Israel... And make every nation and tribe of thine to know that Thou art God, the God of all power and might, and that there is none other that protecteth the race of Israel but Thou (Judith, Charles, p. 258).

Two themes figure in this prayer: on one hand, there is a general appeal for salvation to the God of the patriarchs (not the matriarchs), and Judith beseeches God to save the Jewish people. On the other hand, this is clearly a feminine prayer. The supplicant emphasizes the suffering of women who were raped or taken captive, and prays for a woman to achieve victory. Judith ignores the fallen male warriors (as does Deborah in her hymn of praise) and emphasizes the fact that she is female and a widow. She makes an inter-textual allusion to the hymn of victory sung by Moses and Miriam by quoting the verse: "The Lord, a Warrior - Lord is His name" (Ex. 15:3).

Further on, Judith reveals to the gentile general that she prays every night (11:17) and again at the break of dawn (12:6). When held captive by Holofernes, Judith prays even after her baptism (12:8), apparently continuing her previous habit. Afterwards, right before she kills Holofernes who is lolling drunkenly on his bed, she prays in her heart:

O Lord of all power, look in this hour upon the works of my hands for the exaltation of Jerusalem. For now is the time to help Thine inheritance, and to do the thing that I have purposed to the destruction of the enemies which are risen up against us (Charles, Judith, p. 262). ${ }^{54}$

Later, Judith escapes to Bethulia, and the Israelites pursue their enemies. After this, the Jewish women dance with her, then take palm fronds, crown themselves with olive branches as a symbol of victory and joy, and finally Judith leads all the women in a dance. Chapter 15 (Charles, I, p. 265) of the Book of Judith is devoted to Judith's hymn of victory:

54 The statement that 'The putting of sackcloth on everything in sight... [or] Judith's pausing to pray before chopping off [Holofernes'] head are acts which satirize standard behavior in such settings' seems to me a misunderstanding of (ancient) religious life where every act has a religious meaning. See: A. LaCocque, The Feminine Unconventional (Fortress Press, Minneapolis, 1990), p. 44 (following T. Craven). 
And Judith began to sing this thanksgiving in all Israel, and all the people sang with loud voices this hymn of praise. And Judith said:

Begin unto my God with timbrels,

Sing unto my lord with cymbals

Sing unto him psalm and praise;

Exalt him, and call upon his name.

For the Lord is the God that breaketh the battles....

The Almighty Lord brought them to naught by the hand of a woman

For their mighty one did not fall by young men,

Neither did sons of the Titans smite him

Nor did high giants set upon him;

But Judith the daughter of Merari made him weak with the beauty of her

countenance;

For she put off the apparel of her widowhood.

For the exaltation of those that were distressed in Israel

She anointed her face with ointment

and bound her hair in a tire.

She took a linen garment to deceive him...

I will sing unto my god a new song....

For the mountains shall be moved from their foundations with the waters - and the roots shall melt as wax at thy presence....

This is but a shortened version of Judith's pæan, requiring some elucidation: this hymn, like Deborah's, was an original composition (not a woman's echo of a man's song, like Miriam responding after Moses); it was performed together with other women and accompanied by musical instruments. ${ }^{55}$ Despite certain similarities between Judith's victory hymn and that of Moses and Miriam, Judith's is eminently feminine; her hymn, along with her entire book, belong therefore to our category of feminine prayers.

\section{Sara, wife of Tobias}

The Book of Tobias is one of the most ancient books of the apocrypha and is mentioned in midrashic and medieval sources.56 For our purposes it suffices to present the prayer said by Sara, only daughter of Raguel of Medea. Sara was married seven times and all her husbands died; her maidservants now taunt her. The tearful Sara goes up to the attic, thinking to commit suicide. She raises her hands to heaven and prays:

55 On the different ways of performing the song: by alternating responses, playing musical instruments or dance, see above, ch. 3 .

56 On the Book of Tobias, see: Y. Gafni, Yehudei Bavel bi-tekufat ha-Talmud (Jerusalem, 1991), pp. 54-61 (Hebrew). 
Blessed are You and Your name forever, Merciful God, and may all Your creatures bless You forever. Now, I turn my face and my eyes to You. Pronounce that I shall be lifted from the earth and know no further disgrace. You, my Lord, know that I am pure of the impurity of any man. My name has not been disgraced nor the name of my father in my captivity. I am my father's only daughter and he has no other son to inherit him, nor nephew nor relative for me to marry. Seven husbands I have already lost and why should I still wish to live. If you do not want to take my life, God - heed my disgrace. 57

The desperate and humiliated woman approaches God in a mixture of accusation and pleading. She wants to die, but at the same time, she reminds God that she is righteous (as did Tamar, daughter-in-law of Judah, who had also buried her husband). ${ }^{58}$ At the same time, she states her wish to marry. It should be added that after the marriage, Tobias and Sara pray to God in the bedroom: now it is Tobias alone who prays, while his wife only answers "Amen." Previous to her marriage, Sara had prayed independently, whereas afterwards her prayers are already dependent on her husband's prayer.

The original Book of Tobias underwent subsequent revisions; it now includes Sara's prayer, among others. ${ }^{59}$ After the "marriage prayer," Tobias recites a liturgical poem and prays for salvation:60 "As You answered the prayers of our holy fathers, of Abraham in Ur Kasdim, of Isaac on Mount Moriah, of Jacob in Bethel, and the prayers of all righteous men."61 Immediately afterwards, Sara, too, prays for salvation, and after praising God and adds the following plea:

Now, All Merciful God, listen to my prayer and my tears and remain not silent; as You listened to the prayer of our mother Sara praying over her maidservant Hagar, and the prayer of Rebekah while her two sons struggled in her womb,

and the prayer of Rachel, mother of sons, and of the house, when her sister angered her...

57 An expression of a suicide wish, reminiscent of other women who could not cope with difficult problems and committed suicide. See above, ch. 1.

58 See the incisive study by M.A. Friedman, "Tamar, a Symbol of Life: The 'Killer Wife' Superstition in the Bible and Jewish Tradition", AJS Review, 15 (1990), pp. 23-61.

59 There are several editions of the book. The text quoted here is from M. Gaster, Studies and Texts (Ktav, New York, 1971), III, pp. 1-11. See further: A.M. Haberman, Hadashim gam yeshanim (Jerusalem, 1976), p. 28 (Hebrew).

60 This is a liturgical poem in the ancient format of the genre, and does not appear in any other source: "God of all, Creator of all, mighty over all, knowing all, He who can do all, above all", etc. It is my own opinion that a study of the liturgical poem and the marriage blessing indicates that the redaction of the Hebrew Book of Tobias was done before the fifth century B.C.E.

61 God's victories for the patriarchs are mentioned in a prayer in $\mathrm{m}$. Ta anit 2:4. See also 2 Maccabees, 49-61; b. Pesahim 117a; the geniza amidah prayer, in: I. Elbogen, Hatefillah be-Yisrael behitpathuta ha-historit (Tel-Aviv 1972), pp. 397-398 (Hebrew); D. Goldschmidt, Mehkarei Tefillah u-fiyyut (Jerusalem, 1989), p. $177 \mathrm{ff}$. (Hebrew). 
and the prayer of the prophetess Miriam....

and the prayer of the wife of Elkanah when angered by her rival...

So too shall my prayer rise to You in Your goodwill and I shall be worthy of this man, my husband, and send us Your blessings.

This prayer follows the traditional masculine format, but bears a clear feminine imprint. The redactor of the Book of Tobias attributes the traditional form of prayer to the man, and attributes to the woman a prayer imbued with a feminine character that transcends the traditional form. In her prayer, she cites precedents of God's responding to prayers by women.

\section{Susannah}

In the apocryphal Book of Susannah we learn of Susannah, daughter of Hilkiyah, slandered by the townspeople, who claim that she has committed adultery with a stranger. ${ }^{62}$ Susannah weeps and implores God to prove her innocence: "O Lord, the eternal God, who knowest all things before they come into being, thou knowest that I have not done what these lawless men maliciously allege against me" (Charles, Susannah, p. 649). Once more we have a prayer along the lines of the "Remembrance" liturgy. The praying woman is put on trial before men of flesh and blood, but she considers God her sole judge, and reminds Him that she is a righteous woman. It is therefore no surprise that the text goes on to say that God heeds her prayer, and she is saved.

We have included most of the prayers by biblical women, that is, prayers that pre-talmudic (or even contemporary) traditions attributed to biblical women, in the above discussion. We now turn to women's prayers of a later period.

\section{The first centuries}

Very few allusions to women who prayed have reached us from the first centuries C.E.. The small number of prayers said by women, compared to dozens or more of attested prayers by men, does not necessarily indicate, of course, that women did not pray. Talmudic literature reflects the bias of the masculine authors and compilers, who did not award women or their prayers a place of significance in their works. Let us examine the prayers uttered by women in this period.

62 For more about Susannah, see above, ch. I. 


\title{
1. The wife of Abba Hilkiyah
}

B. Ta`anit 23a-b gives a lengthy account of Abba Hilkiyah and his wife, who prayed for rain (circa the start of the first century C.E.):

\begin{abstract}
Abba Hilkiyah was the grandson of Honi the Rainmaker, and when the world was in need of rain, the sages would send for him to ask for mercy and the rain would fall... One time the world was in need of rain... When Abba Hilkiyah reached the town, his wife adorned herself and went forth to greet him. When he reached his house, his wife entered first and he followed, and then the sages entered... Said Abba Hilkiyah to his wife: "I know that the sages have come here for the rain. Let us go up on the roof and ask for mercy, perhaps God will be appeased and the rain will come, and we will ask for nothing for ourselves." They went up on the roof: he stood in one corner and she in another corner. The first clouds appeared in his wife's corner. He was asked: "Please explain several things: why did the first clouds appear in your wife's corner?" He replied: "Because a woman stays at home and gives bread to the poor." Some thugs lived near Abba Hilkiyah and his wife. He requested mercy and asked for them to die. She requested mercy and asked that they repent, and they repented. ${ }^{63}$
\end{abstract}

This story is not typical of rabbinic literature, telling as it does of the supernatural that causes the rain to fall; the man's grandfather, Honi, was nearly excommunicated by the sages for praying for rain. The husband's title "Abba" is also atypical, as sages are usually called "rabbi". It is difficult to ascertain to what degree this story is representative of the milieu of the sages.

The interesting point in this story is that Honi's grandson, unlike the grandfather, addresses God together with his wife, apparently believing that their joint appeal would be more effective than his solitary one. Moreover, even the direction of the moving clouds proves, according to the author, that the woman's prayer was more potent than her husband's. Furthermore, the woman's superiority is seen in that Abba Hilkiya's prayer for the death of the thugs went unheeded, while his wife's prayer (according to some of the manuscript variants) was answered. ${ }^{64}$ In addition, she was a righteous woman and gave bread to a poor man who appeared at her house. Abba Hilkiya's wife can be considered an exemplary model of a woman praying for the good of the community, whose prayer is heeded by God even more than her

63 For a close reading of this text, see: S. Safrai, "Hasidim ve-anshei ma'aseh", Zion, 60 (1985), pp. 133-154 (especially pp. 141-143, Hebrew). Based on a study of the MSS, Safrai concludes that the last prayer is not authentic, because of the superiority of the wife's prayer.

64 For a similar story, see: S. Buber (ed.), Agadat Bereshit, Wilna 1925 (second ed.), p. 74. 
righteous husband's. ${ }^{65}$ This praying couple can be compared to Isaac and Rebekah; they, too, prayed together, albeit for a private matter. However, while God heeded Isaac's prayer, it is Abba Hilkiya's wife who is more righteous and pious than her husband.

\section{Anna the prophetess}

Another example of a woman's prayer appears in the New Testament: "And there was a prophetess, Anna the daughter of Phanuel, of the tribe of Asher. She was advanced in years, having been married for seven years and then was widowed. At the age of eighty-four, she never left the temple, serving night and day with fastings and prayers" (Luke 2:36-7). The sages held that the vocation of prophecy had ceased to exist hundreds of years before Anna's time, and hence would disqualify this woman as a prophetess. However, they, too, admit that Anna was an exemplary figure of a pious, righteous widow, who spent her time praying to God for the redemption of Jerusalem (even before its destruction by the enemy!). In this respect, Anna resembles Judith: widows with no family obligations, and ample time for prayer. Anna also resembles the praying biblical prophetesses: Miriam, Deborah and the biblical Hannah. Like the biblical mother of Samuel, Anna prayed at the temple (or tabernacle). The biblical Hannah prayed for her private cause; Anna prayed for Jerusalem. She embodies all the positive qualities known to us from the various biblical women, of which she most closely resembles Judith, the daughter of Merari, not a prophetess.

\section{Zaphenat, daughter of Peni'el}

B. Gittin 58a contains the following story, attributed to Resh Lakish about the destruction of the temple,

It is related of a certain woman named Zafenath bath Peniel [she was called Zafenath because all gazed - zofin - at her beauty, and the daughter of Peniel because she was the daughter of the high priest who ministered in the inner shrine] that a brigand abused her a whole night. In the morning he put seven wraps around her and took her out to sell her. A certain man who was exceptionally ugly came and said, "Show me her beauty." He said: "Fool, if you want to buy her, buy for I tell you that there is no other so beautiful in all the world." He said to him, "All the same [show her to me]." He took six wraps off her, and she herself tore off the seventh, and rolled

65 See further in: A. Karlin, "Darkehi ha-sippur beshnei ha-Talmudim", Moznayyim, 11 (1940-1941), pp. 399-408 (Hebrew). For similarities between the wife of Abba Hilkiyah and Beruriah, see: Anne Goldfeld, "Women as Sources of Torah in the Rabbinic Tradition”, Judaism, 24 (1975), pp. 245-256. 
in the dust, saying, "Sovereign of the universe, if Thou hast not pity on us, why hast thou not pity on the sanctity of Thy name?"

This prayer bears the mark of the genre of prayers for salvation, but a closer look reveals more than a hint of bitterness towards God. The tearing of the last robe by the woman herself expresses a kind of spiritual suicide, since now the woman is left exposed; the image is an externalization of the travesty of her modesty. However, despite her personal plight, her plea takes on a religious formulation, an appeal to God to vindicate His own name.

\section{Rabbi Judah's maidservant}

B. Ketuboth 104a tells of the final hours in the life of Rabbi Judah Hanassi. That day, the sages declared a fast and prayed to God that Rabbi Judah would not die. His maidservant went up on the roof and prayed: "The immortals desire Rabbi [to join them] and the mortals desire Rabbi [to remain with them]. May it be the will of God that the mortals overpower the immortals." She does not join in the prayer of the sages, but prays independently to prevent Rabbi Judah's death. The maidservant's prayer resembles the opening of one of the versions of Hannah's prayers, mentioned above: "There is a host above, and there is a host below"; it is well-known that Rabbi Judah's maidservant was proficient in Hebrew. ${ }^{66}$ The story continues: the maidservant saw that Rabbi Judah was wretched due to his frequent need to empty his bowels, changed her request and prayed in defiance of the sages: "May it be the will of God that the immortals overpower the mortals." The sages continued to pray for Rabbi Judah, staving off his death. The maidservant, out of pity for Rabbi Judah, threw a stone from the roof, and the noise made the praying sages fall silent for a moment. ${ }^{67}$ At that precise moment Rabbi Judah died. The wise maidservant defied the sages; however, by causing them to stop praying, she enabled Rabbi Judah to die and be released from his suffering.

\section{The praying maiden}

B. Sotah 22a quotes the following beraita: "Our rabbis have taught - a maiden who gives herself up to prayer, a gadabout widow, and a minor whose months are not completed - behold these bring destruction

66 B. Rosh Hashana 26b.

67 The rabbinic sages told a similar story of David's death - R. Judah Hanassi was a descendant of David: $b$. Shabbat $30 \mathrm{~b}$. 
upon the world." The gemara adds that $\mathrm{R}$. Johanan saw a maiden fall upon her face and recite the following prayer:

Lord of the Universe!

Thou hast created Paradise and Gehinnom,

Thou hast created righteous and wicked.

May it be Thy will that men should not stumble through me.

This prayer is a request by a pious young woman asking God that she not lead men astray. ${ }^{68}$ This form of prayer is couched elegantly, and is the highest moral degree of prayer by a woman, as the prayer is not for herself but for others. There is, however, some self-interest here as well, since she fears punishment for herself if others sin with her. This point is stressed in b. Ta'anith 24a: "R. Jose of Yokereth: My daughter, you are a source of trouble to mankind; return to the dust so that men may not sin because of you." 69 Perhaps the praying maiden, above, feared a destiny similar to that of the daughter of $R$. Jose.

It should be noted that three out of these four praying women (the wife of Abba Hilkiyah, Anna the prophetess, and Rabbi Judah's maidservant) do not belong to the spiritual milieu of the sages. Even when the Talmud quotes a prayer by a woman, it is viewed in a derogatory fashion as potentially harmful, something that "brings destruction upon the world". Although the talmudic sages were familiar with the fact that women did pray, their knowledge of these prayers from outside their own spiritual world was limited.

Following this discussion of over twenty prayers said by women, the majority of which date from the talmudic period, we will now examine the social significance of these prayers.

\section{The social aspect}

The following table presents a schematic view of all the prayers discussed hitherto:

68 See Job 31:1: "I have covenanted with my eyes not to gaze on a maiden", and see below. However, S. Lieberman believed that this referred to a hypocritical, falsely modest maiden. See : S. Lieberman, Mehkarim be-Torat Eretz-Israel (Jerusalem, 1991), p. 204. Similarly, Tur-Sinai interpreted this to refer to a maiden who throws herself at a man, and thus no righteous woman. See: N.H. Tur-Sinai, "Mi-leshon hakhamim umelitzatam be-Masekhet Aboth de-Rabbi Natan", M. Davis (ed.), Jubilee Volume in Honor of M.M. Kaplan (New York, 1953), Hebrew section, pp. 83-93 (especially p. 92, and see the textual variants discussed there).

69 See also: E.E. Halevi, Arkhei ha-halakha ve-ha-aggadah, IV (Tel-Aviv, 1982), p. 202 (Hebrew). 


\begin{tabular}{|c|c|c|c|c|c|c|}
\hline Name & $\begin{array}{l}\text { Type of } \\
\text { prayer }\end{array}$ & $\begin{array}{l}\text { alone } \\
\text { /with } \\
\text { others }\end{array}$ & $\begin{array}{c}\text { original/ } \\
\text { imitation } \\
\text { of men }\end{array}$ & $\begin{array}{l}\text { content: } \\
\text { masculine } \\
\quad \text { or } \\
\text { feminine }\end{array}$ & place & description \\
\hline Miriam & victory & $\begin{array}{l}\text { with } \\
\text { women }\end{array}$ & $\begin{array}{l}\text { imitation of } \\
\text { men }\end{array}$ & & & $\begin{array}{l}\text { prophetess, } \\
\text { Aaron's sister }\end{array}$ \\
\hline Deborah & victory & & $\begin{array}{l}\text { indepen- } \\
\text { dent }\end{array}$ & feminine & & prophetess, judge \\
\hline Hannah & plea & alone & $\begin{array}{l}\text { indepen- } \\
\text { dent }\end{array}$ & feminine & temple & $\begin{array}{l}\text { mother of } \\
\text { Samuel }\end{array}$ \\
\hline Eve & $\begin{array}{l}\text { forgive- } \\
\text { ness }\end{array}$ & $\begin{array}{l}\text { with } \\
\text { husband } \\
\text { alone }\end{array}$ & $\begin{array}{l}\text { imitation } \\
\text { indepen- } \\
\text { dent }\end{array}$ & & & $\begin{array}{l}\text { Mother of all } \\
\text { mankind }\end{array}$ \\
\hline Rebekah & $\begin{array}{l}\text { plea } \\
\text { plaint } \\
\text { thanks- } \\
\text { giving }\end{array}$ & $\begin{array}{l}\text { with } \\
\text { husband } \\
\text { alone } \\
\text { alone }\end{array}$ & $\begin{array}{l}\text { imitation } \\
\text { indepen- } \\
\text { dent }\end{array}$ & feminine & & matriarch \\
\hline Rachel & plea & alone & $\begin{array}{l}\text { indepen- } \\
\text { dent }\end{array}$ & feminine & & matriarch \\
\hline Leah & plea & & & feminine & & matriarch \\
\hline Tamar & rescue & alone & $\begin{array}{l}\text { indepen- } \\
\text { dent }\end{array}$ & & & $\begin{array}{l}\text { Judah's } \\
\text { daughter-in-law }\end{array}$ \\
\hline Aseneth & $\begin{array}{l}\text { forgiv- } \\
\text { eness }\end{array}$ & alone & $\begin{array}{l}\text { indepen- } \\
\text { dent }\end{array}$ & feminine & & $\begin{array}{l}\text { daughter of } \\
\text { priest of On }\end{array}$ \\
\hline$?$ & rescue & alone & $\begin{array}{l}\text { indepen- } \\
\text { dent }\end{array}$ & feminine & & $\begin{array}{l}\text { wife of On son of } \\
\text { Peleth }\end{array}$ \\
\hline Jael & rescue & alone & $\begin{array}{l}\text { indepen- } \\
\text { dent }\end{array}$ & & sty & $\begin{array}{l}\text { wife of Heber } \\
\text { the Kenite }\end{array}$ \\
\hline Eluma & plea & alone & $\begin{array}{l}\text { indepen- } \\
\text { dent }\end{array}$ & feminine & & $\begin{array}{l}\text { mother of } \\
\text { Samson }\end{array}$ \\
\hline Hannah & $\begin{array}{l}\text { plea } \\
\text { plaint } \\
\text { plea }\end{array}$ & alone & $\begin{array}{l}\text { indepen- } \\
\text { dent }\end{array}$ & $\begin{array}{l}\text { feminine } \\
\text { feminine }\end{array}$ & & $\begin{array}{l}\text { mother of the } \\
\text { prophet Samuel }\end{array}$ \\
\hline
\end{tabular}


PRAYERS BY WOMEN

\begin{tabular}{|c|c|c|c|c|c|c|}
\hline Name & $\begin{array}{l}\text { Type of } \\
\text { prayer }\end{array}$ & $\begin{array}{l}\text { alone } \\
\text { /with } \\
\text { others }\end{array}$ & $\begin{array}{c}\text { original/ } \\
\text { imitation } \\
\text { of men }\end{array}$ & $\begin{array}{l}\text { content: } \\
\text { masculine } \\
\text { or } \\
\text { feminine }\end{array}$ & place & description \\
\hline Tamar & $\begin{array}{l}\text { rescue } \\
\text { plaint }\end{array}$ & $\begin{array}{l}\text { alone } \\
\text { alone }\end{array}$ & $\begin{array}{l}\text { indepen- } \\
\text { dent } \\
\text { indepen- } \\
\text { dent }\end{array}$ & $\begin{array}{l}\text { partly } \\
\text { feminine }\end{array}$ & & $\begin{array}{l}\text { king's daughter } \\
\text { wife of the } \\
\text { prophet } \\
\text { Obadiah }\end{array}$ \\
\hline Esther & rescue & alone & & & & queen \\
\hline Sitis & plea & alone & $\begin{array}{l}\text { indepen- } \\
\text { dent }\end{array}$ & & & Job's wife \\
\hline $\begin{array}{l}\text { Amal- } \\
\text { theia's } \\
\text { Horn }\end{array}$ & $\begin{array}{l}\text { thank- } \\
\text { giving }\end{array}$ & & & & & Job's daughter \\
\hline Judith & $\begin{array}{l}\text { rescue } \\
\text { help } \\
\text { victory }\end{array}$ & $\begin{array}{l}\text { alone } \\
\text { alone } \\
\text { with } \\
\text { women }\end{array}$ & $\begin{array}{l}\text { indepen- } \\
\text { dent }\end{array}$ & $\begin{array}{l}\text { feminine } \\
\text { feminine }\end{array}$ & & \\
\hline Sara & $\begin{array}{l}\text { plea } \\
\text { rescue }\end{array}$ & $\begin{array}{l}\text { alone } \\
\text { alone }\end{array}$ & $\begin{array}{l}\text { indepen- } \\
\text { dent } \\
\text { imitation }\end{array}$ & $\begin{array}{l}\text { feminine } \\
\text { feminine }\end{array}$ & attic & $\begin{array}{l}\text { daughter of } \\
\text { Raguel }\end{array}$ \\
\hline Susannah & $\begin{array}{l}\text { rescue } \\
\text { rain } \\
\text { repent- } \\
\text { ance }\end{array}$ & $\begin{array}{l}\text { alone } \\
\text { with } \\
\text { husband } \\
\text { with } \\
\text { husband }\end{array}$ & $\begin{array}{l}\text { indepen- } \\
\text { dent } \\
\text { imitation } \\
\text { indepen- } \\
\text { dent }\end{array}$ & & roof & $\begin{array}{l}\text { daughter of } \\
\text { Hilkiya } \\
\text { wife of Abba } \\
\text { Hilkiya }\end{array}$ \\
\hline Hannah & $\begin{array}{l}\text { redemp- } \\
\text { tion of } \\
\text { Jerusa- } \\
\text { lem }\end{array}$ & alone & & & temple & prophetess \\
\hline Zaphenat & rescue & alone & $\begin{array}{l}\text { indepen- } \\
\text { dent }\end{array}$ & & & $\begin{array}{l}\text { daughter of } \\
\text { Peni'el }\end{array}$ \\
\hline$?$ & plea & alone & $\begin{array}{l}\text { indepen- } \\
\text { dent }\end{array}$ & & attic & $\begin{array}{l}\text { Rabbi Judah's } \\
\text { servant }\end{array}$ \\
\hline$?$ & $\begin{array}{l}\text { preven- } \\
\text { tion of } \\
\text { sin }\end{array}$ & alone & $\begin{array}{l}\text { indepen- } \\
\text { dent }\end{array}$ & & & $\begin{array}{l}\text { maiden on a } \\
\text { pilgrimage }\end{array}$ \\
\hline
\end{tabular}


The above shows a rich variety of prayers composed by different women in different times and places. They span a wide range: requests for rescue and victory; hymns of praise; prayers for children; for rain; for death; for the redemption of Jerusalem; pleas for mercy. ${ }^{70}$ At times women emphasized their inferiority, at others, they stressed their righteousness, and even leveled accusations against God. Most of the prayers are related to death in some manner, since they are usually said in times of dire need. We have already associated the keening women with a death-related function.

The feminine nature of the prayers still requires clarification. A large number of the prayers reflect the supplicant's femininity. More than ten fall into this category: the prayer includes a reference to the fact that it is said by a woman, mentions physical qualities of women, or alludes to clothing or typical belongings of women. However, many of these prayers are in greatest likelihood fictional compositions attributed by men to a female character. Nevertheless, it must still be recalled that the author tried to provide an accurate description of his subject, and so attributed to women prayers similar to those they heard from women in reality. Hence, the assumption that men attributed prayers to women does not necessarily cancel out the original feminine quality of the prayers. Men must have thought that this was how women's prayers sounded, and women, in turn, probably took their cue from this expectation. ${ }^{71}$ The feminine content of the prayers raises the question of what makes traditional prayers "masculine": most of the traditional prayers are said by men and women alike. ${ }^{72}$ Even the prayers that do not bear a distinct "feminine" stamp, then, might have been composed by women.

Finally, we will address the status of women in society, and its expression in prayer. The vast majority of the prayers said by women appear outside of any social context, evidence of a conscious disaffiliation from

70 Other prayers are yet to be analyzed, including: a prayer of a mother for the recovery of her ailing son; the prayer of a woman for her husband to return safely from battle; the childbearing prayer, etc.

71 Cf. C. Ozick, "Notes for finding the right question", D. Rappel (ed.), Hapeninah (Jerusalem, 1989), pp. 129-152 (Hebrew; originally published in Lilith, n.v.)

72 This exception proves the rule: the prayer of thanks "that You did not create me a woman" (t. Berakhot 6:18), which women replace with the prayer of thanks "that You have created me according to Your will" (formulated in the post-talmudic period). However, with this exception, the text of the prayer service is identical for men and women. One other exception is the phrase "and for the covenant that You have marked in our flesh" in the Grace after meals. In some Sepharadi customs women omit this phrase. 
the masculine context. Aside from the biblical story of the prayer of Miriam and other women, Deborah's victory hymn with Barak, and Judith's with her friends - all the other prayers are said by solitary women for themselves, not in the presence of men or even other women.

Women did not, as a rule, pray in the temple or synagogue; sole exceptions are Hannah, mother of Samuel, and the prophetess Anna. This does not prove that women did not pray in the synagogue at all, but it is clear that they took no part in the public ceremony of prayer, and it is doubtful if they were even present in the synagogue during prayer. ${ }^{73}$ Only two of the prayers said by women allude to any fixed habit of prayer on the part of their authors (namely, Judith and Anna the prophetess). Once again, this accords with the observation that most of the prayers were said in connection with death or birth. The time of need has no fixed hour, and the prayers cited above do not teach us anything about women's participation in regular rituals of prayer.

An example of women praying in their hour of need appears in 2 Maccabees, where mature women (not young girls) participate in public mourning. Women participating in public fasting appear also in Pseudo-Philo 30:4, where the prophetess Deborah proclaims: "And now come, let us fast for seven days, from 'man to woman and from the least to the suckling child' (paraphrase of 1 Sam. 15:3; 22:19) (Charlesworth, p. 343). There is no mention here of public prayer, but in pseudoPhilo on Jephtah of Gilead, we read: "and all the people prayed together, men and women and children" (Charlesworth, p. 352). The Book of Judith (4:10-11) emphasizes the role of women on public fast days. The apocryphal books clearly indicate that women were an integral part of the community. A comparison of these apocryphal customs with the description in $\mathrm{m}$. Ta'anit, where women are not mentioned at all, shows that the Mishnah's omission of women is calculated, and we must draw conclusions ex silencio. In the time of the sages, then,

73 On the prayer of women in the synagogue, see: S. Safrai, Eretz-Yisrael va-hakhameha bi-tekufat ha-Mishnah ve-ha-Talmud (Hakibbutz Hameuhad, Jerusalem, 1984), pp. 94 ff. (Hebrew, the evidence that he presents will be discussed elsewhere); S.J.D. Cohen, "Women in the Synagogues of Antiquity", Conservative Judaism, 34 (1980), pp. 23-29; Bernadette J. Brooten, Women Leaders in the Ancient Synagogue (Scholars Press, Chicago, 1982). The conclusive evidence from the talmudic sources about a raised women's gallery refers apparently to Alexandria. See above, ch. 1 (but see Safrai). In the post-talmudic period, conclusive evidence of the existence of a separate women's gallery is available from the ninth century onwards. See: M. Ben Dov, Batei Knesset bi-Sefarad (Tel-Aviv, 1989), p. 47 ff. (Hebrew). 
women did not, as a rule, participate in public fasts and regular public prayers.

One of the differences between biblical and talmudic prayer is that the former was always spontaneous (with the exception of prayers in the Temple), while the sages of the Mishnah and Talmud compiled a canonical liturgy. The canonization of the prayers provided no role for women in the talmudic period. The minority opinion that the obligation to pray included women had little success. Women in antiquity did pray, but not with a regular, fixed text - they prayed spontaneously, especially in times of victory or in the hour of need.

In addition to this difference, of regular, public prayer versus spontaneous, individual prayer, the requirement for modesty also precluded mixed praying. Thus, when prayer began to assume its fixed form, women were excluded and continued to pray spontaneously, as women had done for centuries.

The exclusion of women from praying in a social context, that is, not in a synagogue; and the spontaneous quality of their prayers, highlight the anti-establishment, or individualistic, element of their prayers. Though strong in numbers, women never constituted an organized force. Many of the prayers said by women were occasioned by the behavior of men (for example: Judith, Miriam, Deborah). Women prayed because of men; otherwise, they would not be suffering and would have no need to pray. The sages did not interfere in the prayers said by women, whether because they attribute no value to prayers uttered outside the social institutions, or because they stood on the other side of the sexual divide.

\section{Conclusion}

The many prayers said by women that appear in apocryphal works, compared to the rarity of women praying in biblical stories, demonstrate the intention of the apocrypha to rectify the image of the biblical woman. While the early authors were usually not interested in reporting prayers by women, later authors did so at great length, believing that prayers by women were important. Later authors attributed prayers to great women such as the matriarchs, but also attributed prayers to secondary figures such as the wife of Obadiah, and even the wife of On, son of Peleth, who is not even mentioned in the Bible.

Women prayed separately from men, outside the fixed rituals of the masculine world, and frequently expressed their femininity in prayer. 
Their prayers span a variety of form and content, and were said chiefly in times of dire need. Since feminine prayers were considered unimportant, they were excluded from the canonization of normative - that is, masculine - prayer. An examination of the prayers said by women in antiquity reveals the authentic nature of the affinity between these women and God, even if some of the prayers were in fact written by men in a female persona. ${ }^{74}$

74 On prayers by women in later periods, see: Yael Levine, “Tzena u-re`ena” bekitvei S.Y. Agnon," Bitzron, 9 (New Series), 41-42 (1989), pp. 17-22 (Hebrew). 


\section{CHAPTER 5}

\section{Sorceresses}

Professor Saul Lieberman, on the ocasion of a lecture given by Gershom Sholem, is known to have said: "Nonsense is nonsense, but the history of nonsense is scholarship," referring to the study of Kabbalah; by extension, his observation can also apply to the study of sorcery.

This chapter sets out to examine the feminine aspect of Jewish sorcery in antiquity. Though the study will focus chiefly on the talmudic period, the biblical period will be examined by way of introduction and background. The information presented here serves to facilitate a study of the historical aspect of sorcery in Jewish antiquity and to clarify the pertinent social aspect of this occupation. It will be seen that the history of sorcery is an integral component of any inquiry into the status of women and of men's attitude towards women in antiquity.

\section{The Bible}

Magic and sorcery permeated the ancient world; words were invested with the power of effecting material consequences so that there was no need to resort to action. The believers consulted experts who could change or improve nature, merely by uttering a word. ${ }^{1}$ The Bible bans the practice of any kind of witchcraft whatsoever, and underscores the interdiction several times. Deut 18:10-12 reads:

Let no one be found among you who consigns his son or daughter to the fire, or who is an augurer, a soothsayer, a diviner, a sorcerer, one who casts spells, or one who consults ghosts, or familiar spirits, or one who inquires of the dead. For anyone who does such things is abhorrent to the Lord...

Lev. 19:26 reads: "You shall not practice divination or soothsaying." King Manasseh is castigated for doing "what was displeasing to the

1 See: P. Artzi, "Keshafim”, Encyclopedia Mikrait, IV (Jerusalem, 1963), columns 348-365 (Hebrew); S.D. Goitein, Iyyunim ba-Mikra,3 (Tel Aviv, 1967), pp. 263-264 (Hebrew); Athalya Brenner, The Israelite Woman (JSOT Press, Sheffield, 1985), pp. $67 \mathrm{ff}$. On sorceresses in Mesopotamia, as introduction to the biblical approach to this issue, see: Sue Rollin, "Women and Witchcraft in Ancient Assyria (c. 900-600 B.c.e.)," Averil Cameron and Amelie Kohut (eds), Images of Women in Antiquity (London, 1983), pp. 3445. 
Lord, following the abhorrent practices of the nations that the Lord had dispossessed before the Israelites" (2 Kings 21:2 ff.) and these sins are then stated explicitly: "He consigned his son to the fire, he practiced soothsaying and divination, and consulted ghosts and familiar spirits; he did much that was displeasing to the Lord, to vex Him" (2 Kings 21:6): this interdiction applied to witches and to the practice of witchcraft. Another interdiction appears in Ex. 22:17: "You shall not tolerate a sorceress," adding two new dimensions: the death penalty for those practicing sorcery and the specific mention of women who practice sorcery. This emphasis is unclear, especially given the literary evidence of the activity of sorcerers and not sorceresses. ${ }^{2}$ As a rule, the Bible employs the masculine form to refer to men and women alike; here the interdiction is directed specifically against women. This is perhaps what led the medieval grammarians to the conclusion that מכשפה (mekhashefa) is not the feminine singular of מכשף (mekhashef), but rather a collective noun (like דג daga). ${ }^{3}$

Only one detailed description of witchcraft occurs in the Bible: that of the woman from En-Dor "who consulted ghosts". 1 Sam. 28 tells how Saul, before leaving for his battle against the Philistines, consulted a medium in En-Dor. She called upon the dead prophet Samuel, and from the ensuing conversation between Saul and the medium, we learn that Saul had put mediums and sorcerers to death, in compliance with the decree "You shall not tolerate a sorceress." Indeed, some commentators have it that the medium tricked Saul into thinking that the prophet Samuel himself spoke to him, ${ }^{4}$ but this rationalistic

2 Pharoah's sorcerers and magicians (Ex. 7:11); sorcerers in the court of the king of Babylon (Daniel 2:2); the elders of Moab, versed in divination, who performed spells at the bidding of the king of Moab (Num 22:7). Similar cases of sorcerers appear among the Israelites as well (Micah 3:5). On the other hand, there is no mention of sorceresses (see below) aside from the metaphor employed by Nahum (3:4) comparing Nineveh to a "mistress of sorcery" and a harlot, and by Isaiah (47:9), speaking of "enchantments and countless spells " of Chaldea.

3 This is the opinion expressed by R. Jonah ibn Janah, Sefer ha-Rikma, M. Wilenski (ed.), (Jerusalem, 1964), p. 393 (Hebrew), and see H. Heller, Peshita - Sefer Shemot (Berlin, 1929), p. 100 (Hebrew). The best example of this is the collective noun daga, which is not the feminine form of "dag," neither is ziyya the feminine of $z i$, nor is a hasida the wife of a hasid. In any case, the sages interpreted it differently, see below.

4 See the commentary of R. David Kimhi to 1 Sam. 28:25. He cites an argument between the geonim on the question whether the woman knowingly tricked him, or whether it was indeed sorcery. See also: L. Ginzberg, Ginzei Schechter, I (New York, 1926), pp. 299300 (Hebrew). The Church Fathers were also divided on this question. See: M. Summers, The History of Witchcraft (The Mystic Press, USA not dated, reprint of 1925 edition.), pp. $176 \mathrm{ff}$.; K. A. D. Smelik, "The Witch of Endor: 1 Samuel in Rabbinic and Christian Exegesis till 800 A.D.," Vigiliae Christiane, 33 (1977), pp. 160-179. See also Y. Kaufman, 
interpretation does not change the relevance of the incident for the present discussion about women and sorcery in antiquity. ${ }^{5}$

Jezebel, daughter of the king of Sidon, is also called a sorceress:." How can all be well as long as your mother Jezebel carries on her countless harlotries and sorceries?" (2 Kings 21:2 ff.). A similar connection between licentiousness and sorcery emerges from the invocation of the prophet Nahum of an image of a whore for the city Nineveh: "Because of the countless harlotries of the harlot, the winsome mistress of sorceries" (Nahum 3:4). It seems that it was commonplace to link licentiousness with witchcraft, ${ }^{6}$ both being skills or professions practiced on the fringes of society, catering to the base needs of men. ${ }^{7}$

The prophet Ezekiel (12:17-23) castigated Jewish women who dealt in witchcraft and magic for the purpose of causing death or bringing the dead back to life. Both black magic and white magic - the latter being benevolent sorcery - were considered the domain of women. ${ }^{8}$ The biblical approach can be summed up as follows: the Bible tells of women dealing in witchcraft; though it distinguishes between sorceresses and sorcerers, the Bible does not identify women alone with the practice of witchcraft as thoroughly as do post-biblical sources.

"Ha-Sippur al ba'alat ha-ov," A. Biram (et al., eds.), Sefer Neiger, Ma'amarim be-heker ha-Tanakh (Jerusalem, 1959), pp. 88-95 (Hebrew).

5 See also: Cheryl A. Brown, No Longer Be Silent: First Century Jewish Portraits of Biblical Women (Westminster/John Knox Press, Louisville, Kentucky, 1992), pp. 181-211.

6 The connection between harlotry and witchcraft (in the descriptions of Jezebel and Nineveh) is emphasized in the discussion of the sages of the Canaanites as sorcerers and harlots (Lev. Rabbah, 23:7). In medieval Europe, the casting of spells (causing a miscarriage) and prostitution were frequently mentioned together. See: Shulamit Shahar, Ha-Ma'amad ha-revi'i: ha-Isha be-hevrat Yemei-ha-Beinayyim (Dvir, Tel-Aviv, 1983), p. 114 (Hebrew).

7 The case in which a medium is consulted demonstrates a man's need for a sorceress, but this does not rule out the possibility that women sought out sorceresses too. The Song of Solomon speaks of a woman, possibly a sorceress, who gave a young girl a love-potion: see M. Bar-Ilan, "Behinat ha-nusah, inyanim erotiyyim u-ma'asei keshafim be-migillat Shir ha-Shirim", Shenaton le-Mikra uleheker ha-Mizrah ha-Kadum, IX (1987), pp. 31-53 (Hebrew). The difference between sorcerers and sorceresses was that men served as royal advisers and enjoyed prestigious public positions, while women were consulted by the common people.

8 Ez. 13:19: "You have profaned my Name... in return for morsels of barley and handfuls of bread." This refers probably to the human forms women would fashion out of dough and stick pins into (black magic practiced in medieval Europe, or voodoo in America), i.e. sympathetic magic. It must be recalled that pagan civilization was accustomed to making idols. However, while the statue of a human being made out of wood or stone required artistry and money, the fashioning of a human figure from dough was cheap and required no expertise. 


\section{The Pseudepigrapha}

The affinity between women and witchcraft is rarely mentioned in the apocrypha. The first reference is in 1 Enoch (Ethiopian), composed circa the third century B.c.E., that is, before the completion of the biblical canon. ${ }^{9} 1$ Enoch (chapters 6-8) may be seen as a type of commentary to Genesis 6:1-4, telling how the divine beings took wives from among the daughters of men. 1 Enoch amplifies the terse biblical prose, explaining that two hundred angels, headed by Semyaz (he who sees God) descended upon Mount Hermon:

and they took wives unto themselves, and everyone (respectively) chose one woman for himself, and they began to go unto them. And they taught them magical medicine: incantations, the cutting of roots, and taught them about plants. ${ }^{10}$

That is, humans got their knowledge of witchcraft from the angels (1 Enoch 8:3). The angels taught humans witchcraft, women being the first to practice magic. Man thus attributed all the evil in the world to woman.

The Testament of Reuben 5:5-6 tells how women seduced the giants: "for every woman who schemes in these ways is destined for eternal punishment for it was thus that they charmed the watchers, who were before the flood" (Charlesworth, p. 784). According to the author, then, women did not learn magic from the angels; they were already adept at it, and used magic to entrap the angels. ${ }^{11}$ It seems that this inclusive approach regarding women as the source of witchcraft in the world can serve as an apt introduction to the treatment of this subject in talmudic literature.

\section{The Talmud}

In the first centuries B.C.E. and C.E., Jews were reputed far and wide to be adept in the practice of magic, though no specific mention of women as sorceresses is made. ${ }^{12}$ The predominance of magic in antiquity led

9 Michael E. Stone, Scriptures, Sects and Visions (Fortress Press, Philadelphia, 1989), p. 31.

10 Charlesworth, Apocrypha and Pseudepigrapha, I, p. 16.

11 However, see The Testament of Judah in which the sons of Judah are accused of: "the licentiousness and witchcraft and idolatry that you practice ...following ventriloquists, omen dispensers, and demons of deceit (Testament of Judah, Charlesworth, I, p. 801). On sorcery directed against the authorities, see, for instance, M. Margaliot, Sefer Ha-Razim (Jerusalem, 1967), p. 82 (Heavenly sphere II, 17): "If one seeks to cast a spell on a great number of people, or a ruler, or a judge, or townspeople, or countrymen, etc." (Hebrew). A similar text denouncing spells has been found in Qumran but has not yet been published.

12 On Jews as sorcerers in antiquity, see: Y. Levi, Olamot Nifgashim (Jerusalem, 1960), p. 
modern scholars to address this subject to greater or lesser degree, but the social aspect of witchcraft has hitherto been neglected. The earliest evidence of witches in talmudic literature refers to the non-Jewish witches killed by Simeon b. Shetah, in the first century B.c.E. According to the story in y. Hagigah 2:5, 77d, Simeon b. Shetah had eighty witches hanged in Ashkelon, women who sat together in a cave and plotted and schemed to destroy the world. ${ }^{13}$ The talmudic description dwells in detail on how his men caught the witches, exhibiting familiarity with the witches' practices, ${ }^{14}$ and leaves no room for doubt that there was indeed a historical background underlying this story, though it is not entirely clear. It is difficult to learn from this story if Simeon b. Shetah conquered Ashkelon, or why he killed the witches rather than his enemies. It seems that these witches were idolatrous priestesses, as it is clear that any sorcerer and sorceress must address whatever god they worship. It is therefore evident that Simeon b. Shetah's act should be linked with the drive to banish idolatry from the land. ${ }^{15}$ Be that as it

15 ff. (Hebrew); M. Stern, "Te'ur Eretz-Israel biydei Plinius ha-Zaken va-halukatah ha-administrativit shel Yehudah besof yemei bayyit sheni," Tarbiz, 36 (1968), pp. 215229 , especially p. 219 (Hebrew). See also b. Pesahim 8b, that is, a gentile, seeing the Jew searching for bread, would suspect him of practicing witchcraft. The Jews believed, then, that gentiles thought every Jew was suspect of practicing witchcraft. See also the bibliography in: M.D. Herr, "Inyanei halakha be-Eretz-Israel ba-Me'a ha-Shishit veha-shevi'it lisefirat ha-Notzrim," Tarbiz, 49 (1980), pp. 62-80, note 22 (Hebrew); and M. Bar-Ilan, "Ketivat sefer-torah tefillin mezuzot ukemeiot al or zvi," Beit Mikra, 102 (1985), pp. 375-381 (Hebrew); idem., "Hotamot magiyyim al haguf bein yehudim bameot ha-rishonot la-sefira," Tarbiz, 50 (1988), pp. 37-50 (Hebrew).

13 On different aspects of this act, see E.E. Halevi, Ha-aggada ha-historit-biographit (Tel Aviv, 1975), pp. 81-84 (and the parallel variants: ibid., p. 72), (Hebrew).

14 According to the Talmud, when the men of Simeon $b$. Shetah lifted the women off the ground - their spells were broken. This suggests that they were engaged in some form of worship in the cult of the Earth goddess; moving away from the earth decreased the power of the goddess. See R. Patai, Adam va-adama, 2 (Jerusalem, 1943), pp. 113-119 (Hebrew).

15 See A. Kasher, "Milhamto shel ha-melekh Yannai be-arim ha-Hellenistiyyot beaspaklariyya shel kitvei Yosef ben Matityahu," Cathedra, 41 (1987), pp. 11-36 especially 21 (Hebrew); Y. Efron, "Ma'aseh Ashkelon shel Shimon ben Shetah," Appendix, in: A. Kasher, Cenaan, Pleshet, Yavan ve-Yisrael (Jerusalem, 1988), pp. 222-223; 298-320 (Hebrew). Kasher speculates that the witches were priestesses of Athargatis, the Canaanite Ashtoreth, identified later with the Greek Aphrodite, based on the evidence of cult worship in Ashkelon. Be that as it may, an examination of the type of witchcraft practiced reveals that the witches were occupied mainly in worship of the Earth goddess (Ashthoreth), and not the goddess of the sea (the Ashkelon goddess is described by Diodoros as half-woman, half-fish, following the later Greek type). On witches in antiquity and their identification with female and earth cults, see J.C. Baroja, The World of the Witches (University of Chicago Press, Chicago, 1971), pp . $177 \mathrm{ff}$. 
may, these witches were not Jewish, and can teach us nothing regarding Jewish society in Eretz-Israel in antiquity.

The Talmud links women and witchcraft on several occasions. Mishnah Aboth 2:7 has a saying by Hillel (first century C.E.): "The more possessions the more care; the more women the more witchcraft; the more bondswomen the more lewdness." That is, as the accumulation of property generates worry, it is equally clear that owning many maidservants breeds licentiousness. ${ }^{16} \mathrm{~A}$ woman could seek to cast a spell on a younger woman and make her barren, or cause her not to find favor in the eyes of the master of the house. ${ }^{17}$ The tannaitic literature from the second century c.E. makes several references to the link between women and witchcraft, phrased in extreme terms. In b. Berakhot 53a we find the following halakha:

Our Rabbis taught: "If one was walking outside the town and smelt an odour [of spices], if the majority of the inhabitants are idolaters he does not say a blessing, but if the majority are Israelites he does say a blessing. R. José says: Even if the majority are Israelites he does not say a blessing, because the daughters of Israel use incense for witchcraft.

That is, R. Jose the Galilean (second century) believed that each and every Jewish woman was suspect of practicing witchcraft, of offering incense in idolatrous worship. ${ }^{18}$ The gemara makes an attempt to soften this opinion, saying that only a minority of women who burned incense were engaging in witchcraft, but $R$. José's sweeping generalization - that any incense that one smells derives from the witchcraft of Jewish women - cannot be ignored.

$R$. José's categorical assurance of the inevitable tie between women and witchcraft accords with the opinion attributed to R. Simeon $b$. Yohai, his junior. The discussion in $b$. Eruvin $64 \mathrm{~b}$ refers to the halakha pertaining to a situation in which a person finds food by the wayside: is

16 On "the more bondswomen - the more licentiousness," see S. Assaf, be-Oholei Ya'akov (Jerusalem, 1943), p. 223 (Hebrew).

17 Cf. the commentary of R. Jacob b. Asher (baal ha-Turim) to Deut. 21:15: "Many wives cause much witchcraft; even if a man has two wives, one casts spells to make him hate the other." Another example of a woman casting spells against another is found in Genesis Rabbah 45, 5 (tr. H Friedman and M. Simon, London, 1951, p. 381): "And he went in unto Hagar, and she conceived" - why does it say "you have conceived" - to teach us that Sara cast an evil eye upon her and she miscarried." The quote is based on the textual variants in the Theodor-Albeck edition, p. 453.

18 See, for a case of incense-burning while casting spells, M. Margaliot, Sefer ha-Razim, p. 68 (Heavenly sphere I, 29): "Take myrrh and frankincense on fiery coals for the angel called Orpaniel." On the use of incense and smoke in witchcraft in antiquity (and in later periods), see A. Marmorstein, "Minhagim Kadmonim be-eretz-Yisrael," Ma'assaf Zion, 2 (1927), pp. 17-27 (Hebrew). 
he permitted to ignore it, or must he pick it up. From the story recounted there of R. Gamliel, the gemara concludes that one may not ignore foodstuffs found by the wayside. This opinion raises the following comment:

$R$ Johanan laid down in the name of $R$ Simeon $b$. Yohai: this applies only to the earlier generations when the daughters of Israel did not freeely indulge in witchcaft, but in the later generations, when the daughters of Israel freely indulge in witchcraft, one may pass them by.

R. Simeon b. Yohai believed, then, that the daughters of Israel were wanton and practiced witchcraft, and this would seem to be the opinion held by the majority. Thus, if one finds bread by the wayside - there is a suspicion that the bread is part of a spell (for instance, a figure fashioned out of dough, in order to achieve the death of one's enemy) and thus it is forbidden to pick it up. ${ }^{19}$

In the parallel account in y. Abodah Zarah 1:9, 40a there is a similar, though slightly different opinion. The remark is brought there in the name of R. Abbahu, not R. Simeon b. Yohai, and merely says "because of witchcraft," without specifying women, though it may be assumed that women, not men, baked the bread. A study of the textual variants shows that it is unclear if in fact it was $R$. Simeon $b$. Yohai who voiced these strong opinion against women. However, we do possess another text that may tip the balance in favor of a conclusive identification of $R$. Simeon b. Yohai. in y. Kiddushin 4:11, 66c: ${ }^{20}$

R. Simeon b Yohai taught: "the best among sorcerers - split his head. The most suitable among woman is a sorceress" (Tr. J Neusner, Chicago and London, 1984, p. 252).

R. Simeon b. Yohai was nothing if not consistent: it is he who said that the daughters of Israel are wanton in witchcraft, and also that even the best of women is a sorceress. ${ }^{21}$ Most, if not all, women in Israel were thus suspect of dealing in witchcraft.

19 An example of black magic is found in Pesikta Rabbati 21 "Thou shalt not kill - in the end it is his own wife who practices witchcraft and kills him." The obscure saying about the witches of Ashkelon - that they schemed to destroy the world - may allude to murder committed by women.

20 Mekhilta de R Ishmael, (tr. J. Lauterbach, Philadelphia 1933, p. 201) - The nicest among the idolaters - kill! The best of serpents - smash its brains." The allusion to women was probably purposely omitted. On the other hand, the expression "the best of women practices witchcraft" appears in the name of R. Simeon b. Yohai in Midrash HaGaddol to Exodus (14:7). The full version appears in Tr. Sofrim.

21 Cf. also B.Z. Bacher, Aggadot ha-Tannaim (Tel-Aviv, 1926), vol. II, part I, p. 53, 56 (Hebrew). Note R. Simeon b. Yohai's misogynist opinion of women in b. Shabbat 33b: "Women are frivolous." On this view in antiquity, see E.E. Halevi, Olamah shel haAggadah (Tel-Aviv, 1972), p. 249 ff. (Hebrew). 
Anonymous sayings in tannaitic sources show perhaps that others besides these two sages were of the opinion that most of the daughters of Israel dealt in witchcraft. In b. Sanhedrin 67a, the following baraita is quoted in relation to the verse "You shall not tolerate a sorceress" (Ex. 22:17):

Our rabbis taught - "Thou shalt not suffer a witch to live," this applies to both man and woman. If so, why is a [female] witch stated? - Because mostly women engage in witchcraft. ${ }^{22}$

This opinion precedes the discussion between R. Jos( and R. Akiva. We have here a conclusive opinion regarding the connection of most women with the practice of witchcraft. It would be hard to imagine a greater insult to such a large segment of the population.

It should be noted that Sifre Deut. 11:25, siman 52 reads:

"There shall no man be able to stand against you" (11:25). This refers to a single man; what about a nation, a family, or even a woman plying her witchcraft/ Hence the verse says, 'There shall no man be able to stand' - in any combination (Sifre Deut., tr. by R. Hammer, p.109).

The male author of the midrash, fearful of going to war, shows no fear of strong, experienced warriors, but of a woman, a sorceress wielding her spells against the Israelites. In this case, of course, it would be a nonJewish woman, but it is important to note how dangerous a sorceress was considered in antiquity. Among various peoples, the sorcerer or sorceress would go to war with the troops to aid the general and warriors from afar. ${ }^{23}$ However, before we examine practices in other times and among other peoples, let us turn again to Ex. 17:11. According to the verse, "whenever Moses held up his hand, Israel prevailed; but whenever he let down his hand, Amalek prevailed." The Israelites won that battle due not to their experience or superior military strength, but to the aid of their spiritual leader who was too elderly to take part in the battle himself and was known to practice spells. ${ }^{24}$ The later, tannaitic interpretation (m. Rosh Hash. 2:8) ignored the biblical allusion to magic

\footnotetext{
22 Cf. parallel in y. Sanhedrin 7:16, 25d: “'You shall not suffer a witch to live' - man and woman alike, but the Torah teaches us the way of the world, since most women are sorceresses." It should be noted that many instances of sorcery are cited there in the gemara, all perpetrated by men.

23 Margaret A. Murray, The God of the Witches (Doubleday, Garden City, 1960), pp. 148 ff.

24 J. Neusner, "Science and Magic, Miracle and Magic in Formative Judaism: The System and the Difference," J. Neusner et. al. (eds.), Religion, Science and Magic (Oxford University Press, New York-Oxford, 1989), pp. 61-81; John G. Gager, "Moses the Magician: Hero of an Ancient Counter-Culture?” Helios, 21 (1994), pp. 179-188.
} 
in this account and transformed it into a spiritual understanding with God. However, the tannaitic remarks about the fear of a sorceress going to war against Israel show that they were aware of actions such as those described in the Bible. Such acts of magic were probably still current in their own time, even if they still refused to admit that Moses's actions constituted witchcraft. 25

\section{Another opinion linking women to witchcraft is found in Sifre Deut.:26}

A parable - a certain king issued a decree to the effect that anyone who eats unripe figs grown in the sabbatical year shall be paraded in disgrace around the arena. Now a woman from a noble family proceeded to gather such figs and ate them, and as they were parading her around the arena, she said to the king, "I beg of you, my lord king, let my offense be publicly proclaimed, so that the citizens would not say, she seems to have been caught in an act of adultery or witchcraft" (Hammer, p. 47).

Herein are three sins: a minor transgression of the decree of a king, and two major ones, adultery and witchcraft. According to this approach, just as a woman is likely to commit adultery, she is likely to practice witchcraft. The discussion in the gemara in b. Sanhedrin $100 \mathrm{~b}$ follows along the same lines, revolving around the interpretation of the words of the book of Ben Sira: "A daughter is a vain treasure to her father; through anxiety on her account, he cannot sleep at night." 27 The gemara explains this: "As a minor, lest she be seduced, in her majority, lest she play the harlot; as an adult, lest she be not married; if she marries, lest she bear no children; if she grows old, lest she engage in witchcraft!" This reflects the belief that any woman was likely to practice witchcraft, and nothing could prevent her from doing so.

All the sources mentioned above refer to Eretz-Israel, and it may be assumed that the same beliefs and practices held in Babylonia. There, too, women were considered sorceresses. ${ }^{28}$ A group of sorceresses is

25 In light of this, the verse in Judges 4:8 might be more readily understood: "But Barak said to her: 'if you go with me, I will go; if not, I will not go." Just as Joshua's victory in war depended on a prophet overlooking the fray from a nearby hill, so did Barak want the prophetess Deborah to sit on Mt. Tabor and watch the forces. All the while, she was to carry out various acts to ensure their victory in battle.

26 Parallel: Lev. Rabbah 31, 4.

27 Ben Sira 42:11: "A daughter is a false treasure to her father, he shall not sleep at night for worry." See: M.Z. Segal (ed.), Sefer Ben Sira Ha-Shalem,2 (Jerusalem, 1972, Hebrew) p. 284, where the issue of witchcraft does not appear. See further: M.R. Lehman, "Megillot Yam ha-Melah u-ben Sira," Tarbiz, 39 (1970), pp. 232-247 (Hebrew); Jonas G. Greenfield, "Ben Sira 42.9-10 and its Talmudic Paraphrase," Philip R. Davies and Richard T. White (eds.), A Tribute to Geza Vermes (JSOT, Sheffield, 1990), pp. 167-173. 28 S. Lieberman, Greek in Jewish Palestine (The Jewish Theological Seminary of America, New York, 1942), pp. 97-114. 
mentioned in b. Pesahim 110a: "Amemar said: the chief of the sorceresses told me: He who meets sorceresses should say thus..."29 The leader of that group revealed to Amemar, one of the greatest sages of Babylonia in the fourth century C.E., how he could do away with sorceresses.

A similar piece of advice is found in b. Pesahim 111a, in a discussion of various affairs related to witchcraft:

When two women sit at a crossroads, one on one side of the road and the other on the other side of the road, facing each other, they are certainly engaged in witchcraft.

These examples do not indicate whether these were Jewish sorceresses, but it can be assumed that they were in fact Jewish, especially since a great sage such as Ameimar spoke with the leader of the group. The Jewishness of the sorceresses of Babylonia can be borne out by the story told about the daughters of R. Nahman. B. Gittin 55a recounts the following story: "The daughters of R. Nahman used to stir a cauldron with their hands when it was boiling hot. ...They stirred the cauldron by witchcraft." They apparently stirred the boiling pot on the fire with their bare hands without getting burned. According to the Babylonian tradition cited in the name of a certain R. Ilish, the daughters of an important talmudic sage dealt in witchcraft. ${ }^{30}$

The Babylonian Talmud has preserved the name of one Jewish sorceress, but the full story was apparently excised in compliance with the demands of internal censorship. B. Sotah 22a has "a maiden who gives herself up to prayer, a gadabout widow, and a minor whose months are not completed - behold, these bring destruction upon the world." The gemara cites an example of a righteous, praying maiden and then of a widow. The discussion then proceeds, rightly, to reject the example of the widow, saying that it referred to Yohani daughter of Ratibi. The gemara does not elaborate any further, though Rashi provides a thorough explanation, clearly drawing upon a gaonic tradition, such as that found in the writings of R. Nissim Gaon:

She was a pleasant and good widow in the eyes of men, but she was a sorceress and cast spells on every pregnant woman so that she would not give birth. When the labor pains grew, this widow would come and say: "I will pray for you to the Creator of the Universe and you will deliver your child immediately." Then she would go home and remove the spell and the woman would deliver the child immediately. People thought she was a righteous, pious woman, pregnant women would go to her when

29 On the antidote for the spell, see S.H. Kook, Iyyunim umehkarim, 1 (Jerusalem, 1959, Hebrew). Note that the leader of the group of women advised a man on how to overcome her subordinates, quite possibly in exchange for money.

30 See also: Y. Brand, Klei ha-heres besifrut ha-talmud (Jerusalem, 1953), pp. 487-488 (Hebrew). 
they were about to deliver the child and cajole her to pray for them. One day, she left a young lad guarding her house. The lad heard shaking in the back of the house, but saw nothing. He looked and found a covered barrel. He opened the cover, and found the spells in the barrel, and thus the woman's evil was revealed and the spells were broken. And from that day on, women went to her no more, and the townspeople cast her out from among them. ${ }^{31}$

A woman's name is explicitly mentioned here, an exception to the usual anonymity surrounding sorceresses, in connection with the practical application of witchcraft as birth control in antiquity. ${ }^{32}$ Moreover, the author is aware both of the deception involved in the casting of the spell, as well as of its use by a sorceress as a means of enhancing her own power. In any case, even if this story is not known from the talmudic text itself and despite its pseudo-biblical style, its talmudic origin can be credited. It is difficult however to say with certainty if Yohani b. Ratibi was active in Eretz-Israel (as seems to be indicated from the gemara) or in Babylonia (given the source of the story in the Babylonian Talmud).

\section{The social aspect}

The traditional historiographical approach has ignored women in antiquity; needless to say, it listed witchcraft under the heading of "nonsense". The occasional scholarly forays into the question of

31 In: B.M. Levin, Otzar ha-Geonim, XI, Sotah (Jerusalem, 1942), pp. 241-242. The following different version appears in S. Abramson, "Le-R. Baruch b. Melekh," Tarbiz, 19, (1948), p. 42-44 (Hebrew): "Yohani bat Ratibi was a witch and gave all the women a potion to prevent them from giving birth. She would put the potion in two vessels, and while the two vessels were closed, no women's womb would open. She would pretend to be praying for the woman in labor, and when she would stretch out on the ground to plead, she would open the two vessels, so that the spell was broken, and the woman's womb would be opened. Once, two sages went to ask her to beg for mercy for a woman who was suffering in labor, and found the two vessels containing the spells. They mistakenly opened them; straightforth, the woman's womb was opened and she gave birth easily. Then they knew that she had cast spells." The major differences between this version and that of R. Nissim Gaon are: the elaboration on how the spell was cast; the witch prays; sages and not a youth discover her trickery; there is no attempt to imitate biblical linguistic usage; here the matter of payment to the witch, and her punishment, are lacking. Regarding the so-called spell, see R. Patay, "Masekhet Segulot," Sefer $\mathrm{Ha}$ Shanah le-Yehudei America, 10-11 (1949), pp. 473-487 (Hebrew).

32 It has hitherto been shown that sorceresses were believed to cause unexplained death and to achieve victory in battle; here, they are believed to cast a spell that produced long and difficult labor pains. Rabbi Judah believed (b. Yoma 83b) that a dog would go mad if "spell-casting women played with it", meaning that they would torment a dog until he went mad. According to Ezekiel, women could also restore the dead to life, so that power over life and death, from the process of birth itself, are attributed to women and sorceresses. 
women and sorcery were limited to the sources mentioned above. In the view of the new historiographical approach, however, the subject of women should be treated separately, and all the historical findings about witchcraft should be considered a worthy subject of study with the purpose of ascertaining the social significance of this information. ${ }^{33}$

It remains for us to clarify the degree of historical truth: is there, a feminine tendency to practice witchcraft, and did most of the Jewish women in talmudic times indeed practice witchcraft?

An examination of biblical and talmudic sources does not reveal that women in particular practiced witchcraft. On the contrary: sorcerers outnumber sorceresses in the sources. The books of witchcraft from talmudic times, Harba de-Moshe $e^{34}$ (The Sword of Moses), and Sefer haRazim, are attributed to men, and many of the talmudic examples deal with men practicing sorcery, several even designated by the title "rabbi". Sorcery should therefore not be seen as a particularly feminine occupation. Moreover, there is no historical corroboration for the opinion of R. José the Galilean and R. Simeon b. Yohai that most Jewish women in their time dealt in witchcraft. Two other extra-rabbinical sources also show that all women did not necessarily practice witchcraft: Ben Sira and the scrolls of Qumran. Ben Sira lived in Jerusalem in the second century B.C.E., and displays a fair amount of misogyny, but these do not include any allegation of sorcery; 35 an "essay" on wicked women was discovered in Qumran (4Q184), again without any specific mention of witchcraft. ${ }^{36}$

It may be concluded, then, that the accusation of the practice of witchcraft leveled against women was no more than the reflection of prevailing contemporary beliefs and prejudices, and not an objective historical truth pertaining to Jewish women in antiquity. If so, why were women suspected of practicing sorcery, and all of them at that?

It seems that the answer to this twofold question is to be sought in the social sphere, in the sexual politics of antiquity which decreed women's inferiority. ${ }^{37}$ Two possible explanations for the problem at

33 On the social significance of sorcery (and for a short but largely unsuccessful survey of sorcery in Judaism), see: Daniel L. O'Keefe, Stolen Lightning: The Social Theory of Magic (Vintage Books, New York, 1983), pp. 147-148.

34 On the book Harba de-Moshe, see M. Bar-Ilan, "Ketivat sefer-torah," (above, n. 12), and idem., Sitrei Tefillah ve-Hekhalot (Ramat-Gan 1987), p. 110 ff. (Hebrew).

35 See Ben Sira 25:16-26:4. Cf. the spells that the Talmud attributed to the text of Ben Sira, as cited above, and: W. C. Trenchard, Ben Sira's View of Women (Scholars Press, Chico, 1982).

36 Y. Licht, "Ra'ata shel ha-isha ha-zarah," B. Oppenheimer (ed), Ha-Mikra vetoldot Yisrael: le-Zikhro shel Ya'akov Liever (Tel-Aviv, 1972), pp. 289-296 (Hebrew).

37 On the status of women in Jewish society in the time of the Mishnah and Talmud, 
hand will be proposed, both of which relate to the structure of ancient society; the two proposals, though perhaps incompatible, do complement each other: any inclusive categorization of women by men, especially such a severe accusation as the practice of witchcraft, is rooted in prejudice. This is the only possible explanation for the categorical tone of this accusation, though it is not yet a solution to the problem. The origin of the accusation that women practiced witchcraft is embedded in the very structure of male opinions about men's superiority and women's inferiority. These opinions were not held by Jews alone, of course; harsh misogynist prejudices were rife among the gentiles of the period, even more so than among Jews. ${ }^{38}$ In any case, the association of women with witchcraft was but a part of the overall process of the demonization of women, in which women were accused of consorting with the devil himself. ${ }^{39}$ This example of men's derogatory attitude towards woman is in keeping with their overriding suspicion of women as a threat to the "strong" sex - despite the blatant reality of men who killed women, not vice versa. The cause of such beliefs lies in the structure of traditional societies in which inequality between the sexes reigned, resulting in permanent tension. ${ }^{40}$

Accusations of witchcraft exacerbated the mutual tension, and the strong grew stronger at the expense of the weak; accusations against the physically and politically weaker sex became a program for a solution for all ills of society. The scapegoat is thus found (women, in this case, or the Jews, in another social context) and blamed for all the ills and misfortunes of the ruling masculine society, or the Christian society,

see: L. Swidler, Women in Judaism: The Status of Women in Formative Judaism (The Scarecrow Press, Metuchen, N.J. 1987); Leonie J. Archer, "The Role of Jewish Women in the Religion, Ritual and Cult of Graeco-Roman Palestine," Averil Cameron and Amelie Kuhut (eds.), Images of Women in Antiquity (note 1), pp. 273-287.

38 On views of women in the talmudic period compared to the Hellenistic world, see E.E. Halevi, Arkhei ha-Aggadah veha-halakha, 4 (Tel -Aviv, 1982), p. 198 ff. (Hebrew).

39 On the ancient link between women and the devil, see Genesis Rabbah 17:6 (tr. H. Friedman and Maurice Simon (London: Soncino, 1951), p. 137: "R. Hanina, son of R. Adda said: From the beginning of the Book until here no samech is written, but as soon as she [Eve] was created, Satan was created with her. While should one quote, "That is it which compasseth" - sobeb - (Gen. 2:11) answer him: the text refers there to rivers." The text can be altered (by writing "Satan" with a samech, in order to link the creation of Eve with Satan). According to Kiddushin 81a, Satan, when mingling with human beings, assumes the form of a woman. Christian theology developed this idea extensively, and woman is considered the devil's partner. See S. Ashkenazi, Ha-Isha baaspeklaryiyat ha-Yahadut, 1 (Tel-Aviv, 1943), p. 81 ff. (Hebrew).

40 This explanation holds for other times and places as well, where witchcraft was attributed chiefly to women. See Shulamit Shahar (above, n. 6), p. $223 \mathrm{ff}$. 
which it is incapable of resolving. ${ }^{41}$ The association of women with sorcery illuminates the dynamics of the oppression of the weak and the way in which the ruling class constantly strengthens its political position.

A further aspect of the sexual division on the present issue should be noted. In effect, all the sources expressing derogatory opinions of women's sorcery are masculine. All the sources cited above were composed, to the best of our knowledge, by men like R. José and R. Simeon b. Yohai, who accused women of sorcery. However, it must be noted that R. Simeon b. Yohai, who castigated women as sorceresses, actually practiced sorcery himself. He is said to have exorcised a demon that had entered the body of the emperor's daughter (b. Megilla 17b). ${ }^{42}$ It was R. Simeon b. Yohai who turned his eye upon one of his opponents and transformed him into a heap of bones (y. Shevi'it 9:1, 38d). He was adept at casting an "evil eye," and other miracles were attributed to him as well. ${ }^{43}$ When R. Simeon b. Yohai, then, employs supernatural means, it is a miracle; when a woman does the same thing, however, it is witchcraft. Moreover, when Moses threw a staff and it turned into a snake it was a sign from God, but when an Egyptian did the same thing, it was sorcery. Clearly, then, the dividing line in antiquity between miracle and spell depended on both the religion and sex of the agent.

One social aspect of witchcraft can now more readily be understood. The emphasis in the sources on women's involvement in sorcery cannot be ignored; even if reduced to more modest proportions, the references are still substantial. The attribution of witchcraft to women derives from the very essence of the traditional society, its social institutions and the human desire for power. ${ }^{44}$ Political power was limited to men in antiquity; a few queens reigned but they were a negligible minority in the ruling masculine world. Traditional society cut women off from the sources of power and leadership in all fields. Women were

41 E.E. Evans-Pritchard, "Witchcraft Explains Unfortunate Events," William A. Lessa and Evon Z. Vogt (eds.), Reader in Comparative Religion, 2nd ed. (Harper and Row, New York, Evanston and London, 1965), pp. 328-332.

42 See: M. Bar-Ilan, "Exorcism by Rabbis: Talmudic Sages and Magic", Da'at, 34 (1995), pp. 17-31 (Hebrew).

43 Cf. $y$. Shevi' it for how he raised the dead from their graves in Tiberias; a similar use of the "evil eye" (b. Shabbat 33b); creating gold (Ex. Rabbah 52,3).

$44 \mathrm{Cf}$. the approach explaining feminine witchcraft as aggression and male sorcery as defensive: Esther Goody, "Legitimate and Illegitimate Aggression in a West African state," Mary Douglas (ed.), Witchcraft, Confessions and Accusations (Tavistock Publications, London, 1970), pp. 207-244. However, this explanation is far from convincing, as it merely transfers the question to another conceptual system. See also: N. Rubin, Reshit Hahaim (Tel-Aviv, 1995), p. 27 (Hebrew). 
excluded from war, which required a man's physical strength, but were also excluded from serving in the capacity of political or personal advisors which required no physical strength at all. Women, then, were denied access to the sphere of social leadership. This being so, it seems that the tendency among women to practice witchcraft served as a means of expressing the feminine desire for power. As normative society banned women from attaining positions of leadership from within, women would try to overcome the ban and to achieve a different sort of power. Women's involvement in witchcraft in antiquity expressed their desire to attain a position of power from outside the accepted social institutions that were closed to them.

King Saul, in seeking out the advice and professional services of a sorceress, was carrying out the will of a woman. Men who went to war would consult a sorceress to inquire what day was favorable for battle: the perfect example of the sway women held over men. Though in traditional society, man used women for their own needs - biological or psychological (desire for power) - sorceresses demonstrate the reverse: women making use of men for their own purposes - control and submission. The subversive activity by sorceresses was the sole option open to them, since normative channels were blocked to women. For this reason, society, ruled by men, views these acts as deviation. ${ }^{45}$

This background explains the transformations that the Israelites underwent. Whereas the biblical period had prophetesses, charismatic women in positions of influence and power, this means of attaining power was no longer feasible for women in the talmudic period. Prophecy had disappeared altogether and religious leadership had passed to the sages and was based on the teaching of the oral law, which was forbidden to women. There was not a single woman in the masculine world of the sages, and women had no influence on general society. For a woman with leadership potential, or, shall we say, a woman with the power to manipulate others, her sole recourse for expression was outside institutionalized frameworks, through witchcraft, for example. Even if the women themselves did not accord any importance to this occupation, masculine society enabled women to wield influence only by subversion. Women managed to find a way to make men do their will. This can be seen as a kind of revenge exacted by women on the

45 Shahar (above, n. 6) presents an interesting approach for the solution of a similar problem in a different culture. On one hand, she believes, rightly, that women joined heretical movements in order to improve their social standing, since it afforded a greater degree of equality than did mainstream traditional society. On the other hand, in her attempt to explain the link between women and witchcraft, she resorts to psychological approaches (p. 244) that seem to lack adequate foundation. 
masculine world that spurred them to become involved with the supernatural. It is thus clear that with the evolution of civilization, including Jewish society, and the move towards the promotion of equality, talented women could reach positions of decision-making and leadership (over men as well), a development which rendered witchcraft no longer relevant.

It follows that the accusation leveled by men against women is ultimately self-incrimination, since it reveals the glaring inequality created by men towards women. Sorcery as practiced by women constituted insurrection against the social structure no less than sorcery practiced by men, and was much less destructive than men's usual activities. If women turned to sorcery, this stemmed indirectly from the male oppression that frequently brought about the opposite result: women, as sorceresses, gained control over the men who needed them.

Finally, we must address the issue of how widespread was the belief that all women were practicing sorceresses. A comparative analysis of sorcery among Jewish women of antiquity and women in Europe and America in the sixteenth and seventeenth centuries is most instructive. ${ }^{46}$ In two completely different societies, women were accused of practicing witchcraft, but the outcome was entirely different. In EretzIsrael there was nothing resembling a witchhunt, and aside from the non-Jewish witches killed by Simeon $b$. Shetah, we have no knowledge of any Jewish woman put to death for being a sorceress, despite the biblical injunction. In Christian Europe, however, more than a millennium and a half later, accusations of witchcraft were the cause of the death of hundreds of women and some men, over a period of about two hundred years. ${ }^{47}$

Perhaps the reason that Jewish society refrained from acting upon its prejudices is that the sages lacked any real political power, while, in Christian society, the religious authorities could put their beliefs into

46 Much has been written on this issue. See: H. R. Trevor-Roper, "The European WitchCraze," M. Marwick (ed.), Witchcraft and Sorcery (Penguin Books, Harmondsworth, 1970), pp. 121-150. Cf. also to the study on the history of religions and the extensive bibliography there, in: Mircea Eliade, Occultism, Witchcraft, and Cultural Fashions (The University of Chicago Press, Chicago and London, 1976), pp. 69 ff. Interesting statistics appear also in S. Ashkenazi, Ha-Isha ba-aspaklariyyat ha-Yahadut, 1, p. 85 ff. (Hebrew).

47 Trevor-Roper's article refers to Europe in general, cf. an article discussing a single area in England, surveyed over a period of about 120 years: A. Macfarlane, "Witchcraft in Tudor and Stuart Essex," Mary Douglas (ed.), Witchcraft, Confessions and Accusations, pp. 81-99. The author examines the statistics that indicate that $2.5 \%$ of the population were accused (!), among them over $90 \%$ were women, $40 \%$ of these widows. About $20 \%$ of the accused were executed or died in prison. 
practice in the form of a trial and execution. ${ }^{48}$ The witch hunt in Europe seemed like a direct continuation of the Spanish Inquisition against the Jews; in both cases the Christian establishment wielded its power against minorities - Jews and women.

The significance of the difference between the two societies is revealed in the consequences of their attitudes: death on the one hand, compared with prejudice alone on the other. This essential difference may show how the act of accusing someone of the practice of witchcraft became a social tool not only for the ruling class that stood to gain strength by putting its opponents to death, but as a social means of controlling population growth. It must be recalled that precisely while the cruel witch-hunt was in progress, European population was growing, following centuries of zero growth, even demographic regression (during the years of the plague). In a society that practiced no birth control, the threat of over-population was very real. Burning women at the stake, in the name of religion, provided some means of controlling the problem. In the popular mind, women were responsible for birth, and the death of a woman would decrease population more effectively than the death of a man..$^{49}$ This, then, may provide an explanation as to why women were so frequently accused of witchcraft. 50

It is perhaps impossible to provide proof for this deterministic explanation; ${ }^{51}$ even if incorrect, it still raises interesting questions about the wretched situation of women in antiquity and the start of the modern era, physically and politically inferior in a masculine society. Moreover, the data and social insights gathered here may serve the needs of any ruling social class, though this oversteps the boundaries of the present discussion.

48 This explanation can be only partly true, since ancient Rome, for instance, did exercise the death penalty for witchcraft, though only rarely. On the nature of the occupation of witches, their link to prostitution and their beliefs, in medieval Italy and ancient Rome, (based on the description of Horatio) see: J. Burckhardt, The Civilisation of the Renaissance in Italy (tr. S.G.C. Middlemore, London: George Allen - New York: The Macmillan, 1914), pp. 524-540.

49 The reverse was practiced regarding sacrifices at the Jerusalem temple. Male animals were sacrificed almost exclusively, clearly so as not to decrease the population of animals for sacrifice in the future.

50 It should be noted that Trevor-Roper (above, n. 46) attributes the witchhunt to religious tension in Christendom. Nevertheless, it cannot be denied that it is relevant to the present discussion, as his explanation answers only part of the social questions discussed here.

51 At the same time, see the explanation that views the cessation of witch trials as stemming from the rise of rationalism and the decline of religious belief (this explanation fails to deal with the differences between the two societies): $R$. Thomas, Religion and the Decline of Magic (Penguin Books Harmondsworth, 1973), pp. 681-698. 


\section{Conclusion}

The issue of women and the practice of witchcraft is perhaps a minor chapter in the role of sorcery in Jewish history, but it is certainly central to the history of the status of women in Judaism in antiquity. Whereas in the biblical period, the connection between women and witchcraft was not conclusive, as time went on the association between women and sorcery became firmly established. The apocrypha is the median point, both chronologically and ideologically, telling how women practiced witchcraft, though stopping short of the Mishnah's dictum that all women, even the most pious, were initiated into the practice of sorcery.

There is no doubt that the study of witchcraft merits anlaysis in the fields of history as well as the social sciences. We have suggested that the link between women and witchcraft was a result of the inferior status of women in antiquity. On the one hand, sexual politics led to the accusation of the weak of demonic activities that threatened the stronger sex. Thus, the ruling class strengthened its position and took advantage of the weakness of the inferior class of women. On the other hand, social inequality brought about-if not outright then indirectlya situation in which charismatic women dealt in witchcraft, if only to attain a degree of social power and status denied them by men. ${ }^{52}$

52 On Jewish witches in medieval Italy see: A. Toaff, Love, Work, and Death: Jewish Life in Medieval Umbria (translated by Judith Landry, The Littman Library of Jewish Civilization, London, 1996), pp. 118-124. 


\section{CHAPTER 6}

\section{Prostitutes}

Despite the Bible's severe standards of sexual mores, there is no explicit injunction against prostitutes. This is not to imply that the prophets viewed it with equanimity: numerous verses voice vehement opposition to prostitution, and the prophets employed it frequently as a figurative representation of moral-religious transgressions. ${ }^{1}$ Of the relations between God and the people of Israel, the metaphor of a loving married couple was frequently used. ${ }^{2}$

The lack of any explicit biblical injunction against visiting a prostitute seems to reflect the profound insight that, though prostitution is never an honorable profession, neither is it a crime on the same scale as stealing or murder. Legislators of old realized the futility of trying to ban prostitution altogether, as it had always been an inseparable part of civilization. ${ }^{3}$

The objective of this chapter in painting a picture of prostitution in antiquity, especially in Eretz Israel, is historical, not moral. The issue bears upon the entire social structure in antiquity, as well as upon the sexual politics of the time. Clearly, evidence of any kind of contact between the sages and prostitutes would shed new light on the social standing of the sages, as will be seen below. Let us now turn to our first source.

\section{The Bible}

In the biblical period there were two (perhaps three) types of prostitutes in Eretz Israel and throughout the Ancient Near East: temple prostitutes who performed sexual acts as part of cult worship and ordinary

1 S. Lewonstamm, "Zenunim", Encyclopedia Mikrait, II (Jerusalem, 1954), columns 935-937 (Hebrew); Louis M. Epstein, Sex Laws and Customs in Judaism (Ktav Publishing House, New York, 1967), p. 152 ff. See also: R. Patai, Family, Love and the Bible (MacGibbon and Kee, London, 1960), pp. 131 ff.; John H. Otwell, And Sarah Laughed: The Status of Women in the Old Testament (Westminster Press, Philadelphia, 1977), pp. 158-160; Athalya Brenner, The Israelite Woman (JSOT Press, Sheffield, 1985), pp. 78 ff.

2 See M. Bar-Ilan, "Mistika ve-erotika: hazad hashaveh shebein ha-shetayim ba'et ha-Atika," Mahut, I (1990), pp. 141-146 (Hebrew).

3 The idea of abolishing all prostitution from the land was familiar in the religious domain, and perhaps it, too, was based on economic motivation. See: Ez. 16:41; Ps. 73:27. 
prostitutes providing sexual services for money. Obviously the cult prostitutes, acting in the name of religious worship, enjoyed greater social prestige than the others, motivated by the need to earn their livelihood. ${ }^{4}$ The Bible denounces contact with either kind; approaching a cult prostitute was perhaps castigated more harshly, since the practice reinforced the idolatry that the Israelites sought so fiercely to abolish.

Biblical literature barely alludes to direct contact with prostitutes; for the prophets, prostitution became a literary image for women's faithlessness. In fact, only isolated incidents of men engaging prostitutes are mentioned: Judah went to a prostitute, or so he believed (Gen. 38) until he discovered that the woman was none other than his daughter-in-law Tamar, in disguise. ${ }^{5}$ Judah promised to send the woman a kid from his flock as payment, with his Adullamite friend: "he inquired of the people of that town, 'where is the cult prostitute,' only to hear the reply, "there has been no prostitute here." 6 There was apparently only a minimal difference between a cult prostitute and an ordinary prostitute. When the Israelites crossed the desert, "the people profaned themselves by whoring." The text continues: "The people partook of [sacrifices for their god] and worshipped that god" (Num. 25:1-2). Idolatry was also the cause of the plague that wiped out twenty-four thousand Israelites.

The prophets pronounced the following injunction against ordinary prostitutes and cult prostitutes: "No Israelite woman shall be a cult prostitute, nor shall any Israelite man be a cult prostitute. You shall not bring the fee of a whore or the pay of a dog into the house of the Lord your God in fulfillment of any vow, for both are abhorrent to the Lord

4 An instructive analysis of the extra-biblical sources, in an attempt to ascertain the origin of the custom, can be found in: E. Westermarck, The History of Human Marriage, 5th ed. (MacMillan, London, 1925), I, pp. 207-235. On the status of prostitutes in Mesopotamia and determining the historical reliability of testimony describing cult prostitution in Canaanite worship, see: M. Gruber, "Kedesha", Beer-Sheba, III (1988), pp. 45-41 (Hebrew); Richard A. Henshaw, Female and Male: The Cultic Personnel (Pickwick Publications, Allison Park, PA, 1994), pp. 191-256.

5 Note the difference: Tamar, daughter-in-law of Judah, "rapes" a man (like the daughters of Lot), while Tamar, daughter of David (descended from Judah and Tamar) herself is raped. In both cases the degree of kinship on both sides makes the union forbidden by biblical law.

6 Note how Tamar's appellation changes. In Gen 38:15 "he took her for a harlot; for she had covered her face" (Gen 38:15). It continues with Judah asking the local people "Where is the cult prostitute" (Gen 38:21), and later he is told "Your daughter-in-law Tamar has played the harlot", (verse 24), and Judah rules that she be burned (as in Lev. 21:9). See also: Michael C. Astour, "Tamar the Hierodule", JBL, 85 (1966), pp. 185-196; Mordechai A. Friedman, "Tamar, A Symbol of Life: The 'Killer Wife' Superstition in the Bible and Jewish Tradition", AJS Review, 15 (1990), pp. 23-61. 
your God" (Deut. 23:18-19). For the prophets, then, this combination of worship and sexual acts was abhorrent, and they forbade Israelites men and women alike - from serving as cult prostitutes or taking part even indirectly in the cult worship of such prostitutes. For instance, if a cult prostitute received a $\mathrm{kid}$ as payment and came to the temple to fulfill a vow - such as promising to sacrifice a kid if God granted her a child - the temple priests were forbidden to accept the kid as sacrifice. From this prohibition (and from external sources), we learn that the word "dog" here refers to a male prostitute hired by women for sexual relations. The payment received by male prostitutes was also banned from the temple. Cult prostitutes, termed an abomination by the prophets, acted in or adjacent to the temple, as in the pagan cults of the time (and of early Islam). ${ }^{7}$

The spies sent by Joshua to Canaan found shelter with the prostitute Rahab in Jericho. This indicates that prostitutes lived close by the city walls, where a constant stream of strangers passed by. Samson, too, went to a prostitute in Gaza (presumably a non-Jewish one), but the social context of these incidents is unclear. ${ }^{8}$

The famous judgment of Solomon, demonstrating the king's great wisdom, teaches us also that prostitutes lived together in communities, with their children. These children were obviously raised in sorry conditions. ${ }^{9}$ Child mortality points to neglect, but motherly feelings still stirred the prostitutes, sparking fights over their parental rights to the survivor. Even when a child of a prostitute grew and became a man of great prowess, he, as an illegitimate child, never inherited his father as legitimate children did. ${ }^{10}$ We learn this from the case of Jephthah. His attitude to his only daughter, whom he sacrificed to God, is somehow

7 A biblical example of this are the sons of Eli who "lay with the women who performed tasks at the entrance of the Tent of Meeting" (1 Sam. 2:22). Women came to the temple (asking God to grant them a child, for instance). The barren woman is most humiliated in the Bible. See also: M. Baer, "Banav shel Eli beaggadat Hazal", BarIlan, 14-15 (1977), pp. 79-93 (Hebrew).

8 Josh. 2:1; Judg. 16:9. According to the pseudo-Philo apocryphal composition (43:5), Delilah was a prostitute, though this is not stated explicitly in the Bible.

91 Kings 3:16 ff. It should be noted that in the case of Rahab and at Solomon's trial, the king speaks to prostitutes, showing that the social standing of the prostitutes was not as lowly as might have been imagined: see further below.

10 Judg. 11:1 ff., and see Astour, above, n. 6. In the biblical period the child of a prostitute was considered a bastard: "No one misbegotten shall be admitted into the congregation of the Lord" (Deut. 21:3). For this reason, bastards were not allowed to take part in the community, as happened to Jephtah who "was the son of a prostitute... they drove Jephthah out... So Jephthah fled from his brother and settled in the Tob country" (Judg. 11:1-3). 
linked to his own childhood as a prostitute's son growing up without a father. ${ }^{11}$

In the time of King Jeraboam (tenth century B.c.E.), The Bible says, "There were also male prostitutes in the land" (1 Kings 14:24), who served in the cult worship. A woman would come to pray to God, and the priest would have sexual relations with her. The verse continues: "Judah imitated all the abhorrent practices of the nations that the Lord had dispossessed before the Israelites." It is clear that the prophets denounced this worship. Of King Asa we read: "Asa did what was pleasing to the Lord, as his father David had done. He expelled the male prostitutes from the land, and he removed all the idols that his ancestors had made. He also deposed his mother Maacha from the rank of queen mother, because she had made an abominable thing for [the goddess] Asherah. Asa cut down her abominable thing and burned it in the Wadi Kidron" ( 2 Kings 15:11-13).

King Asa killed male prostitutes who served idolatrous cults, and even deposed his mother Maacha from her position as priestess to Asherah, who is identified with the goddess Ashtoreth. From the fact that the biblical author mentions, in the same breath, idolatrous cults to both gods and goddesses, presumably male prostitutes worshipped Baal, while Asherah was served by female prostitutes. This might explain the beliefs, held even in the highest social circles in Jerusalem, that the god had a wife $\mathrm{w}^{12}$ and the god and goddess each required cult prostitutes.

Though Asa abolished male prostitution, it did not die out, as we learn from the description: "He also stamped out the remaining male prostitutes who had survived in the land from the time of his father Asa" (I Kings 22:47). However, as Asa was unable to abolish male prostitution entirely, it may be assumed that his son Jehoshaphat was equally unsuccessful.

The death in battle of Ahab, King of Israel, is described in the following manner: "and they flushed out the chariot in the pool of Samaria. Thus the dogs lapped up his blood and the whores bathed [in it], in accordance with the word that the Lord had spoken" (1 Kings 22:38).

11 In psychological terms, a prostitute's son can be said to exact his revenge upon the women who raised him, and sacrificed his beloved daughter just as fathers sacrificed their male children (Abraham, the king of Moab (2 Kings, 3:27). The social position of bastards improved over the years, and only marriage was forbidden to them. In the Middle Ages, commentators held that Jephthah's daughter was not really sacrificed, but she lived a life of abstinence. See L. Ginzberg, Legends of the Jews (Ramat-Gan, 1975), V,p. 140 (Hebrew).

12 This is not the place to discuss these opinions, but see M. Weinfeld, "Yoman Pirsumim", Shnaton le-Mikra uleheker ha-mizrah ha-kadum, 4 (1989), pp. 280-284 (Hebrew). 
The dogs and whores were allowed to defile the blood of Ahab. "Dogs" are the male prostitutes, as their mention alongside the prostitutes shows. It is possible that the dogs licking the king's blood and the bathing in the blood were part of the cultic worship of male or female temple prostitutes serving Baal and the goddess Kibla. ${ }^{13}$

The Bible tells us that King Josiah scourged Jerusalem to abolish idolatry from the city in the last third of the seventh century B.C.E. He removed the altars from various places in the country. He also did the following:

He brought out the image of Asherah from the House of the Lord to the Kidron Valley outside Jerusalem, and burned it in the Kidron Valley; he beat it to dust and scattered its dust over the burial ground of the common people. He tore down the cubicles of the male prostitutes in the House of the Lord, at the place where the women wove coverings for Asherah. (2 Kings 23:6-7).

Like Josiah's restoration of the Jahweh cult, Asa's campaign for the purging of idolatry included uprooting the asherah (either a tree or the image of the goddess) from the House of the Lord and banishing the male prostitutes from the temple God, a place frequented by women too. Here and in other descriptions, it can be seen that these women were both prostitutes and priestesses. Until that time, it was apparently customary in Jerusalem to combine sexual acts with religious worship. The phrase "where the women wove" does not bear any sexual connotation, but their mention in proximity to the allusion to male prostitutes indicates that the women who wove (clothes for the goddess, presumably) also engaged in sexual acts of cult worship. ${ }^{14}$

A manifestation of the connection between prostitutes and the cult milieu can be seen in the character of the wife of the prophet Hosea. The prophet is instructed by God: "Go, get yourself a wife of whoredom and children of whoredom," (Hosea 1:2) and the prophet went and married Gomer daughter of Diblaim. ${ }^{15}$ In the pagan world as well as in the Yahweh cult, going to a prostitute could be a religious act. ${ }^{16}$

13 A. Margalit, "Al Kalbei Ahab", Sefer Dr. Baruch ben-Yehudah, B.Z. Luria, ed. (TelAviv, 1981), pp. 248-258 (Hebrew); M. Zipor, "What were the Kelabim in Fact?", ZAW, 99 (1987), pp. 423-428.

14 See: 1 Baruch 10:19; b. Ketubot 106a; Pesikta Rabbati 26, 131a. The weaving women, like the women who keened over Tammuz (see Ch. Three) in the temple, and male prostitutes in the houses, also engaged in sexual relations in the temple courts. Temple prostitutes brought their payment to the altar, and would dress the goddess and feed, wash and anoint her.

15 For an explanation of this matter and of the name Gomer in particular, see: Y. Dvir, Yiuda shel ha-shlihut ba-shem ha-mikra'i (Tel-Aviv, 1969), p. 191 (Hebrew).

16 On the opinion held by the commentators that such a marriage never took place, see: 
Cult prostitution was abolished in one form, only to reappear in another. Evidence of this, though not fully clear, appears in the Scholion of Megillat Ta'anit for the date of the twenty-third of the month of Marheshvan: "for the gentiles built a site there and stood the prostitutes upon it, and when the house of the Hasmoneans grew strong, they took it from them and destroyed it." 17 The Hellenist rulers reinstated idolatry in the temple, along with the practices of prostitution, which the prophets and kings of Israel had tried to abolish centuries earlier.

In any event, at the close of the First Temple period or a short while later, cult prostitution disappeared, leaving only ordinary prostitutes in the land, as seen in talmudic sources, which, due to the nature of the documents, provide information lacking in biblical accounts.

\section{The Talmud}

There are quite a few anecdotes about prostitutes in talmudic literature. This anecdote became familiar after its inclusion in the prayerbook. ${ }^{18}$

\section{$1 \mathrm{~B}$. Menahot 44a quotes the following baraita:}

Once a man, who was very scrupulous about the precept of zizith, heard of a certain harlot in one of the towns by the sea who accepted four hundred gold [denars] for her hire. He sent her four hundred gold denars and appointed a day with her. When the day arrived he came and waited at her door, and the maid came and told her, "The man who sent you four hundred gold denars is here and waiting at the door," to which she replied, "let him come in." When he came in, she prepared for him seven beds, six of silver and one of gold, and between one bed and the other there were steps of silver, but the last were of gold. She then went up to the top bed and lay down upon it naked. He too went up after her in his desire to sit naked with her, when all of a sudden the four fringes [of his garment] struck him across the face, whereupon he slipped off and sat upon the ground. She also slipped off and sat upon the ground and said, "By the Roman Capitol, I will not let you alone until you tell me what blemish you saw in me." "By the Temple," he replied, "Never have I seen a woman as beautiful as you

Y. Jacobson, Hazon ha-mikra, I, Tel-Aviv 1962, pp. 346-350 (Hebrew). The modern feminist approach emphasizes the husband's violence towards his wife: "Else will I strip her naked... and let her die of thirst"), and issues that were removed from the world of the ancient commentator. See: T. Drora Setel, "Prophets and Pornography: Female Sexual Imagery in Hosea," Letty M. Russell, (ed.), Feminist Interpretation of the Bible (Basil Blackwell, Oxford, 1985), pp. 86-95; Renita J. Weems, "Gomer: Victim of Violence or Victim of Metaphor?", Semeia, 47 (1989), pp. 87-104.

17 See: H. Lichtenstein, "Die Fastenrolle", HUCA, 8-9 (1931-2), p. 337.

18 See Z. Baer, Seder Avodat Yisrael (Redelheim, 1868), p. 536 (Hebrew). The passage is included in the "Ma'amadot" prayers for Friday. On these prayers, see: I. Ta-Shema, "Mekora uMekoma shel Tefilat 'Alenu Leshabeah' beSidur haTefila: Seder haMa'amadot veSheelat Siyum haTefila," B. Walfish (ed.), The Frank Talmage Memorial Volume, I (Haifa University Press, Haifa, 1993), pp. 85-98 (Hebrew). 
are, but there is one precept which the Lord our God has commanded us, it is called zizith... Now [the zizith] appeared to me as four witnesses testifying against me." She said, "I will not leave you until you tell me your name, the name of your town, the name of your teacher, the name of your school in which you study the Torah." He wrote all this down and handed it to her. Thereupon she rose and divided her estate into three parts: one third for the government, one third to be distributed among the poor, and one third she took with her in her hand. The bedclothes, however, she retained. She then came to the Beth ha-Midrash of R. Hiyya and said to him, "Master, give instructions about me that they make me a proselyte." "My daughter," he replied, "perhaps you have set your eye on one of the disciples?" She thereupon took out the script and handed it to him." "Go," said he, "and enjoy your acquisition." Those very bedclothes which she had spread for him for an illicit purpose, she now spread out for him lawfully. ${ }^{19}$

Although the main theme of this story is the commendation of the wearing of ritual fringes as protection from sinful behavior, another theme appears: the contact between sages and prostitutes. A disciple in the study-house, a man known to the teacher, apparently a rich man who traveled overseas, presumably to Rome, went (like Samson) to a prostitute, and not a cheap one, either. ${ }^{20}$ She eventually converted to Judaism and came to Eretz Israel. Evidently even among the sages there were some who consorted with prostitutes, and non-Jewish ones to boot. $^{21}$

2 Another edifying story about the contact between sages and prostitutes is found in $b$. Abodah Zarah 17a:22

19 The parallel is in Sifre Num. 115. The best text of the Sifre is Rome MS 32. The textual variants in the Sifre are minor compared with the Talmud, and it seems that the compiler of the Sifre, for reasons of modesty, did not state explicitly that they were naked. For more on this story, from a different perspective, see: A. Goshen-Gottstein, "Mitzvat zizit, ha-zonah ve-ha-sippur ha-darshani", Ts. Groner and M. Hirshman (eds.), Mahshevet Hazal: Divrei ha-Kenes ha-Rishon (Haifa, 1990), pp. 45-58 (Hebrew).

20 The price of four hundred zuz is clearly literary hyperbole (like the four hundred boys and girls, Chapter One, above). Compare to the prostitute's fee discussed below. On the payment of prostitutes in antiquity, see: Sarah B. Pomeroy, Goddesses, Whores, Wives and Slaves: Women in Classical Antiquity (Robert Hale, London, 1975).

21 The following story in b. Megillah $14 \mathrm{~b}$ is attributed to R. Nahman: "Eight prophets who were also priests were descended from Rahab the harlot... She became a proselyte and Joshua married her." (see Chapter One). This is a case of a prostitute who converted to Judaism, married one of the great men of the time, and became the ancestor of prophets. The same idea appears in Matthew 1:5: "And to Salmon was born Boaz by Rahab". According to the common historical background of these legends with the story discussed here, apparently one or more of the prominent men of the time consorted with a non-Jewish prostitute, who converted to Judaism, engendering a line that included sages. 22 According to S. Abramson (ed.), Abodah Zarah MS (New York, 1957), p. 29. In another version the title "rabbi" is added (along with a prayer to pagan gods). However, only after he repented and died did a voice from heaven call out "rabbi", and the text continues: "Rabbi said: it is not enough that those who have repented are accepted - 
It was said of R. Eleazar b. Dardoya that he did not leave out any harlot in the world without coming to her. Once, on hearing that there was a certain harlot in one of the towns by the sea who accepted a purse of denarii for her hire, he took a purse of denarii and crossed seven rivers for her sake. As he was with her, she blew forth breath and said: "As this blown breath will not return to its place, so will Eleazar b. Dardoya never be received in repentance." He thereupon went, sat between two hills and mountains and exclaimed: "O, ye hills and mountains, plead for mercy for me!" The replied: "How shall we plead for thee? We stand in need of it ourselves." ... "Heaven and earth, plead ye for mercy... Ye stars and constellations...." Said he: "The matter then depends upon me alone!" Having placed his head between his knees, he wept aloud until his soul departed. Then a bath-kol was heard proclaiming: "Rabbi Eleazar b. Dardoya is destined for the life of the world to come."

In this story, too, a Jew visits an expensive prostitute in another country. Both sinners repented: indeed, the main theme and purpose of the Talmud in recounting the tales was to encourage repentance; the authors of the story show great awareness and understanding of human weakness. This time there is a tragic ending, with the only glimmer of optimism being Elazar b. Dardoya's reward in the hereafter. The only unusual element in this story is Elazar b. Dardoya's appeal in prayer to forces that can be construed as angels of God, contrary to the prevailing opinion of the talmudic sages. ${ }^{23}$ Elazar b. Dardoya apparently did not belong to the circle of sages. Only after his repentance did he merit the title "rabbi". The story shows that a Jew, known to the sages, though his connection with the study-house is not clear, went to a prostitute, and ultimately repented.

3 B. Berakhot 23a (and an allusion in y. Berakhot 1:3, 4b) tells a story in the context of a halakhic discussion: "One who enters a regular privy takes off his tefillin at a distance of four cubits and puts them in the window on the side of the public way and enters."

For a certain student once left his tefillin in a hole adjoining the public way, and a harlot passed by and took them, and she came to the Beth ha-Midrash and said, "See

they are also called "rabbi." See also: M. Baer, "Al Ma`asei kapara shel ba`aleiteshuva besifrut Hazal," Zion, 46 (1971) p. 159-181 (and especially p. 163, Hebrew).

23 Of prayers to angels, see E.E. Urbach, The Sages: Their Concepts and Beliefs (Harvard University Press, Cambridge, Massachusetts - London, 1994), pp. 181-183. Regarding this particular prayer (the appeal to angels), see The Fathers According to R. Nathan, Ver. A, 12. In the past there were many more prayers like Elazar b. Dardoya's, as can be learned from the text of the prayer said by Moses in the following sources: Yehudah Hadassi, Eshkol ha-Kofer (Gozlaw, 1836), 109b (Hebrew); A.M. Habermann, Helkat Mehokek (Jerusalem, 1947), p. 62 ff. (Hebrew). Compare these prayers to the prayer to the sun and moon for Adam in The Book of Adam and Eve 36,2. Note that, in fact, this prayer is quite different from extant prayers of repentance or confession: there is no recognition of $\sin$ here, nor of resolve to act properly in the future. 
what So-and-so gave me for my hire," and when the student heard it, he went to the top of a roof and threw himself down and killed himself. Thereupon they ordained that a man should hold them in his garment and in his hand and then go in.

This story is recounted in order to explain halakhic change regarding the proper placement of phylacteries when entering a privy. However, a close reading of the gemara shows that it was not only the prostitute who removed the phylacteries from their hiding-place; mice and other passers-by did so as well. The historical context still remains in need of clarification, and its historical truth cannot be determined conclusively: did the sage really leave his phylacteries in the hands of a prostitute as a pledge of payment (as did Judah), or did she frame him? Did she herself remove the phylacteries from their hiding place without having had any contact with the disciple?

The publicity that the prostitute gave her actions and the suicide of the suspect incriminate him, implying that he did in fact visit the prostitute. ${ }^{24}$ The prostitute in this story is credible, unlike Tamar: it will be recalled that Tamar was sentenced to be burned for engaging in prostitution, until she produced the seal, the candle and the staff belonging to Judah. Here, however, the prostitute was not the accused but the accuser, leading to the conclusion that she was having her fun. She knew exactly where the sage customarily hid his phylacteries and took advantage of the opportunity to inculpate him. What did she hope to gain? The death of Elazar b. Dardoya, who undoubtedly consorted with the prostitute, and of the disciple in the second story, seem to point to their guilt. Death would seem to follow upon sin, according to the principle "death exonerates sin." This points to the probability that the disciple did indeed visit the prostitute and was not unfairly accused.

The disciple, then, went to a prostitute and left a pledge with her (or forgot his phylacteries, having taken them off there). ${ }^{25}$ Since he did not pay, the woman came to the study-house to collect her due. Preferring death to public humiliation, he committed suicide. From the redaction

24 Cf. a similar story in b. Sanhedrin 11a: "A story is related of a woman who appeared at the Beth haMidrash of R. Meir and said to him, "Rabbi, one of you has taken me to wife by cohabitation." Thereupon he rose up and gave her a bill of divorce, after which every one of his disciples stood up in turn and did likewise." R. Meir did not claim that the woman framed one of his pupils - he accepted her claim and gave her a divorce to protect the disciple's reputation, though he was neither identified nor vilified altogether (see m. Kiddushin 1:1).

25 Cf. Pesikta Rabbati 22, 11b on blasphemy: "One may not wear his phylacteries, and wrap himself in the tallith, and then go commit sins." Thus, Eleazar was saved from sin thanks to his prayer shawl, which he did not remove; the disciple who removed his phylacteries was not saved from sin. Cf. M. Bar-Ilan, "Ve-samu et shmi al benei Yisrael", HUCA, 60 (1989), Hebrew section, pp. 19-31 (especially 28 ff.) 
of the story it seems that his colleagues did not suspect him of seeing a prostitute.

4 B. Hagigah 15a tells how God wishes all sinners to repent, except for the apostate Elishah b. Abuyah. The sage says:

"Since I have been driven forth from yonder world, let me go forth and enjoy this world." So Aher went forth into evil courses. He went forth, found a harlot and demanded her. She said to him, "Art thou not Elisha b. Abuyah?" [But] when he tore a radish out of its bed on the Sabbath and gave it to her, she said: "It is another [Aher],"

Theoretically at least, the sages were supposed to be above the need for such worldly pleasures. For b. Abuyah, leaving the social circle of the sages was a physical act, symbolized by his visit to a prostitute. (How did the prostitute recognized the sage by name - does this imply previous acquaintance?)

5 Further examples of the connection between the sages and prostitutes appear in two stories in b. Bava Metzia 85a:

Rabbi chanced to visit the town of R. Eleazar son of R. Simeon. "Did that righteous man leave a son?" he inquired. "Yes," they replied, "and every harlot whose hire is two zuz hires him for eight." So he had him brought before him, ordained him a Rabbi, and entrusted him to R. Simeon b. Isi b. Lacunia.

Rabbi chanced to visit the town of R. Tarfon. Said he to them, "Has this righteous man who used to swear by the life of his children, left a son?" "He has left no son, but a daughter's son remains, and every harlot whose hire is two zuz hires him for eight." He had him brought before him, and said to him: "Should you repent, I will give you my daughter." He repented.

The first story suggests that $\mathrm{R}$. Simeon $\mathrm{b}$. Yohai's grandson, Yossi, was a male prostitute. Ordained "rabbi," he studied with R. Simeon b. Isi b. Lacunia and proved that he was deserving of his title. R. Tarfon's grandson was also involved in prostitution, but repented.

Both stories were redacted in the same dialogic format to show that grandsons of rabbis still belonged to the milieu of the sages by virtue of their family merit. Repentance is a possibility even for those who strayed and engaged in prostitution. Though the picture painted here is lurid, telling how female prostitutes hired male prostitutes to satisfy their lust, ${ }^{26}$ still we learn that the grandsons of R. Simeon b. Yohai and

26 This picture of a female prostitute hiring a male prostitute to satisfy her sexual appetite seems farfetched, but the idea recurs again in the words of R. Hisda in $b$. Abodah Zarah 17a: "Every harlot who is hired, ends up hiring." Evidently the practice existed in antiquity. 
of R. Tarfon (end of the second century C.E. or beginning of the third) regularly visited prostitutes. Furthermore, the first story shows how someone of the lowest spiritual level can still be called "rabbi," despite not having studied.

6 B. Pesahim 113a-b reports the opinion of R. Yohanan: "Concerning three does the Holy One, blessed be He, make proclamation every day: a bachelor who lives in a large town without sinning, etc." This tradition was recited before Rabah in Babylonia, and he interpreted it according to the following story:

R. Hanina and R. Oshaia were cobblers in Eretz Israel and dwelt in a street of harlots and made shoes for harlots and went in to them. They (the harlots) looked at them, but they (the scholars) would not lift their eyes to look at them, and their (the harlots') ${ }^{27}$ oath was: "by the life of the holy rabbis of Eretz Israel."28

A man indeed needs great strength of character to work in the prostitutes' market and deal with them as customers, without sinning. We know from talmudic literature of sages who overcame their desire and did not commit adultery (a sin worse than going to a prostitute). ${ }^{29}$ Here, two sages lived among prostitutes and were on familiar terms with them; nevertheless, they refrained from contact with them. However, the following story shows that this was the rare exception.

7 The homily in Ex. Rabbah 43:7 (tr. S.M. Lehrman, London, 1939, p. 502) in the name of R. Yohanan explains how the Israelites in Egypt came to practice idolatry:

27 The Rashbam's commentary interprets the oath as one said by the prostitutes. However, I believe the oath was common to all inhabitants of Babylonia, who, hearing the story of the righteousness of the sages in Eretz Israel, would use this formula of an oath. Cf. the Rabbanan Kaddish prayer: "For Israel and for the sages... in this holy place and in every place," preceded by "by your life," which is the formula of an oath.

28 Cf. Num. Rabbah 9,7: "From where is it known that Israel are called holy when they abstain from adultery and licentiousness? As it is written, (Lev. 20:7), "You shall sanctify yourselves and be holy, for I the Lord am your God."

29 See the series of miracles attributed to R. Hanina b. Papi, R. Zadok and R. Cahana in b. Kiddushin 39b-40a. They withstood temptation when ordered to sin with a "matron," a gentile woman of high social standing. See other miracle stories about Amram the Hasid, R. Meir and R. Akiva in b. Kiddushin 81a, and the story about R. Matya b. Harash in Yalkut Shimoni on Gen., 161 (and in Tanhuma Buber, Vilna 1885, p. 131); Midrash Aseret Ha-Dibrot, A. Yellinck, Beit Hamidrash (Jerusalem, 1938), I, pp. 7980 (where Satan appears before the sage "as a beautiful woman, of beauty unmatched since Na'ama, sister to Tuval Cain.” B. Kiddushin 61 b recounts how R. Hiyya b. Ashi's wife disguised herself, called herself Harutha (Rashi: the name of a well-known prostitute in the town); her husband then approached her as a prostitute. 
It can be compared to a wise man who opened a perfumery shop for his son in a street frequented by harlots. The street did its work, the business also did its share; and his youth likewise contributed its part, with the result that the son fell into evil ways. When the father came and caught him amidst the prostitutes, he began to shout: "I will slay thee!" But his friend was there, and he said: "Thou wert the means of destroying [the character] of this youth, and yet thou dost shout at him! Thou didst ignore all other professions and hast taught him only to be a perfumer, and thou didst forsake all other districts and hast opened a shop for him just in the street where prostitutes dwell!"30

This story presumably draws upon actual circumstances to show how a young man is easily led astray when finding himself in the company of prostitutes.

8 An additional encounter between sages and prostitutes, similar to the story of the righteous men in Eretz Israel, appears in b. Abodah Zarah 17a-b:

$R$. Hanina and $R$. Jonathan were walking on the road and came to a parting of ways, one of which led by the door of a place of idol-worship and the other led by a harlots' place. Said the one to the other: "Let us go [through the one leading] by the place of idolatry, the inclination for which has been abolished. The other however said: "Let us go [through that leading] by the harlots' place and defy our inclination and have our reward." As they approached the place, they saw the harlots withdraw at their presence.

The story tells of two sages in Eretz Israel in the third century c.E. Their act of bravery was to pass by a brothel, withstand temptation and refrain from entering. When the prostitutes saw the sages, instead of approaching them as they would do to any customer, they hid inside the brothel. They were presumably Jewish women who feared the sages would recognize them.

This was improper behavior for a sage, as the following interpretation shows In (The Fathers According to R. Nathan, Version B, 3, tr. A Saldarini, Leiden 1975, p. 47):

Where are we told that the Writing made a hedge about their words? Scripture says: "Keep your way far from her [a loose woman]," (Prov. 5:8.) A man is told: "Do not walk down this street or enter this alley, for there is a prostitute here; she is an attractive woman and she seduces all creatures by her beauty." 31 He said: "I am

30 The same story appears in b. Berakhot 32a: "It is like the case of a man who had a son; he bathed him and anointed him and gave him plenty to eat and drink and hung a purse round his neck and set him down at the door of a bawdy house. How could the boy help sinning?".

31 A good example of how a woman, not necessarily a prostitute, "drew everyone after her by her beauty" can be fond in the positive comments made by Zrubabel about women in the apocryphal 3 Ezra, 4:13-32. 
confident that although I walk (there), I won't look at her and I won't desire her beauty." He is told: "Although you are confident, don't go."32

While some sages avoided passing through the marketplace frequented by prostitutes, others made no effort to avoid such encounters.

\section{B. Abodah Zarah 18a-b tells how and why R. Meir entered a brothel:}

Beruria, the wife of R. Meir, was a daughter of R. Hanina b. Teradion. Said she [to her husband], I am ashamed to have my sister placed in a brothel. ${ }^{33}$ So he took a tarkah full of denarii and set out. If, thought he, she has not been subjected to anything wrong, a miracle will be wrought for her, but if she has committed anything wrong, no miracle will happen to her. Disguised as a knight, he came to her and said, "Prepare thyself for me." She replied, "The manner of women is upon me." "I am prepared to wait." he said. "But," said she, "there are here many, many prettier than I am." He said to himself, that proves that she has not committed any wrong, she no doubt says thus to every comer... Others again say that Elijah the Prophet appeared to them as a harlot who embraced him. God forbid, said they, were this R. Meir, he would not have acted thus! and they left him. He then arose and ran away and came to Babylon.

There are several levels of meaning in this story, and it is difficult to determine its historical truth. R. Meir was spotted by Jews, apparently in Rome, embracing a prostitute, but since they could not believe he would do such a thing they gave him the benefit of the doubt. The following story in The Fathers According to $R$. Nathan, Version A, chapter 8, (tr. J. Goldin, New Haven, 1955, p. 51) ${ }^{34}$ recounts that R. Meir was involved in such a situation:

32 See the parallel in Version A, 2: "Do not enter this alley, as there is a prostitute there, attractive and fine... so that one does not grow accustomed to passing by the door of a harlot, as it is written: "For many are those she has struck dead, and numerous are her victims' (Prov. 7:26)."

33 He followed the Israelite into the chamber and stabbed both of them, the Israelite and the woman, through the belly" (Num. 25:8). As to knowledge of the sister's presence in the brothel (confirmed by other sources), Sifre Deut. 32, 4, 307 has: "They said to his daughter: it is decreed that your father be burned and your mother killed, and you must go to work." "To work" is clearly a euphemism for prostitution. However, Midrash HaGadol on Gen. 27:3, has "to do work on the Sabbath"; this shows that the compiler or scribe did not understand the denotation of "work" in this context, and related it to the ban on doing any labor on the Sabbath. The same thing happened in b. Megilla 12b: "This [remark] teaches you that the wicked Vashti used to take the daughters of Israel and strip them naked and make them work on Sabbath." The words "on Sabbath" are redundant here, as the issue is not the desecration of the Sabbath, but rather, prostitution carried out before the queen for her enjoyment (Cf. b. Gittin 58a).

34 Cf. other stories of a similar character in b. Shabbat 127b; The Fathers According to R. Nathan ibid. and Version B, ch. 19, p. 41; all these stories imply that the sages faced strong sexual temptation. 
And judge everyone with the scale weighted in his favor. There was once a young girl who had been taken captive, and two saintly folk went after her to ransom her. One of them entered the harlots' apartment. When he came out he asked his companion: "What didst thou suspect me of?" The other replied: "Of finding out perhaps for how much money she is being held." Said the first: "By the Temple service, so it was!" and he added: "Even as thou didst judge me with the scale weighted in my favor, so may the Holy One, blessed be He, judge thee with the scale weighted in thy favor."

The circumstances underlying R. Meir's visit to the brothel recur elsewhere: it stands to reason that the Roman enemy, like other conquering armies, used female prisoners as prostitutes, and several references to this appear in talmudic literature..$^{35}$ It transpires from the story that $R$. Meir went to redeem his sister-in-law from the brothel, redemption of prisoners being an important commandment. Jews frequently did so for relatives and fellow Jews taken prisoner. ${ }^{36}$ After it was discovered that R. Meir bribed the brothel's guard, R. Meir had to escape to Babylonia. There is a marked legendary stamp to this story, and we can presume that the historical reality was less noble. Nevertheless, the story's underlying message is that Jewish women were prostitutes in the Roman empire after they were captured in Eretz Israel. Some of these women were ransomed and freed, while others remained, unless they committed suicide or died of grief.

10 Lamentations Rabbah 1 (16, 46, tr. A. Cohen, London 1939, pp. 127-8) tells the following story of prisoners and prostitutes:

It is related that the two children of Zadok the priest, one a boy and the other a girl, were taken captive, each falling to the lot of a different officer. One officer resorted to a harlot and gave her the boy [as a slave]. The other went to a store-keeper and gave him the girl for wine... After a while the harlot brought the boy to the shopkeeper and said to him, "Since I have a boy who is suitable for that girl, will you agree that they should marry and the issue will be divided by us?" He accepted the offer... They embraced and kissed until they expired. Then the Holy Spirit cried out, "For these things I weep."

Here, then, is another incident of the treatment of Jewish women in captivity at the hands of Roman soldiers. This time, the woman was a slave in a merchant's house. The sister did not engage in prostitution, but her brother was taken to a prostitute, probably as payment. His fate is unclear, but we have already seen above that at times female

35 See Amos 7:17: "Your wife shall play the harlot in the town, your sons and daughters shall fall by the sword." Compare to the girls who jumped into the sea, aware that they were going to be used as whores, above, Chapter One.

36 A. Bashan, Sheviyya u-fedut ba-hevra ha-yehudit bearzot ha-yam ha-tikhon (RamatGan, 1980), p. 21 ff. (Hebrew). 
prostitutes would hire male prostitutes: perhaps the young prisoner was required to provide sexual services. The ending was tragic. The brother and sister were not ransomed, and died of grief. Jewish prisoners men and women alike - shared the bitter fate of enforced prostitution.

11 M. Horayot 3:7 speaks of the commandment to redeem prisoners (The Mishnah, tr. H. Danby, Oxford 1933, p. 466):

A man must be saved alive sooner than a woman, and his lost property must be restored sooner than hers. A woman's nakedness must be covered sooner than a man's and she must be brought out of captivity sooner than he. When both stand in danger of defilement, the man must be freed before the woman.

This halakha appears in t. Horayot 2:5, (The Tosefta, tr. J. Neusner, New York, 1981, p. 351), where the term "disgrace" is used in reference to a brothel. ${ }^{37}$ The following story appears there:

R. Joshua went [to Rome], and they told him: "There is here a child from Jerusalem with beautiful eyes and a handsome face, and he is in danger of shame." $R$. Joshua went to look into the matter. When he came to the door, he recited this verse... At that instant said R. Joshua: "I call to testify against me the heaven and the earth, that I shall not move from this spot until I shall redeem this child!" He redeemed him for a huge sum of money and sent him to the Land of Israel.

In this story, a youth from Jerusalem was taken prisoner, brought to Rome and sold to a brothel of male prostitutes. Luckily for him, unlike in the previous incident, he was freed, and ultimately became a scholar.

12 The following story appears in Lam. Rabbah (I, 39, tr. A. Cohen, London 1939, p. 116):

R. Phinehas said: It happened that two harlots of Ashkelon were quarreling. In the course of the quarrel one said to the other, "You should not go out because you look like a Jewess." They subsequently became reconciled, and the one said, "I forgive you everything you said except the remark that I look like a Jewess."

The midrash recounts that even among the non-Jewish prostitutes of Ashkelon, the lowliest of the gentiles, the standing of the Jew was lower still. R. Phinehas wanted to interpret the verse Lamentations 1:11: "See, O Lord, and behold, how abject I have become!" but apparently he knew that it was a true story.

37 The denotation of 'kalon' is disgrace and humiliation, and it is linked to prostitution in Hosea 4:18: "Disgrace is the 'gift' which the wind is bringing." 


\section{In the New Testament}

The gospels telling of the Jews in Eretz Israel in the first century C.E. include several references to prostitutes. ${ }^{38}$ The Greek verb porneo recurs several times, designating adultery committed with a married woman, not a visit to a prostitute. ${ }^{39}$ The prostitute, as in biblical literature, was the most abject and shameful person imaginable. Thus, for instance, in First Corinthians 6:12-20 the author tells his disciples: ${ }^{40}$

Yet the body is not for immorality, but for the Lord, and the Lord is for the body... Do you not know that your bodies are members of Christ? Shall I then take away the members of Christ and make them members of a harlot? May it never be! Or do you not know that the one who joins himself to a harlot is one body with her? For He says, 'the two will become one flesh.' But the one who joins himself to the Lord is one spirit with him. Flee immorality...

The dichotomy stressed here is between the spiritual and the material, with the prostitutes exemplifying the most physical. This resembles the above description of Elishah b. Abuyah. It must be noted that in all talmudic literature there is no categorical halakha against going to a prostitute. There are, of course, general expressions of denunciation, but no explicit halakha, such as the one before us. ${ }^{41}$ This might reflect the reality of the sages' environment, where going to a prostitute was not condoned but it nevertheless existed (whether for religious or social reasons). It is difficult to draw conclusions ex silencio. In any case, different information is learned of prostitutes from the words of Jesus to the priests and elders in the temple in Jerusalem:

Jesus said to them: "Truly I say to you that the tax-gatherers and harlots will get into the kingdom of God before you. For John came to you in the way of righteousness and you did not believe him, but the tax-gatherers and harlots did believe him; and you, seeing this, did not even feel remorse afterwards so as to believe him" (Matthew 21:31-21).

According to this, the tax-gatherers and prostitutes believed in John the Baptist, while the priests did not. This speech lacks historical context, such as when and where such an event took place. However, Jesus presumably was right, and the tax-gatherers and prostitutes did believe in John the Baptist, who derived his authority not from official

38 On this matter, see: S. Legasse, “Jésu et les prostituées”, Revue Théologique de Louvain, 7 (1976), pp. 132-154.

39 See, for instance: Acts 15: 20, 29; 21:25; Revelation 9:21.

40 New American Standard New Testament (California, 1975).

41 In Miqsat Maasei HaTorah (B:80-82): "But you know that some of the priests... and pollute the [holy] seed... with harlots". See: E. Qimron and J. Strugnell, Discoveries in the Judean Desert, X - Qumran Cave 4, V (Clarendon Press, Oxford, 1994), pp. 56-57. 
social standing or power, but from his extraordinary personality. ${ }^{42}$ Such a charismatic figure could find disciples among tax-gatherers and prostitutes, but not among the priests and elders. Tax-gatherers are portrayed negatively in talmudic literature, ${ }^{43}$ and, of their mention along with prostitutes, it can only be said that like attracts like. An incident similar to the one in which the sage who was meticulous in his observance of the commandment to wear ritual fringes succeeded in causing a prostitute to repent also happened to the prostitutes who believed in John the Baptist. That incident did not take place in a brothel, where men come to satisfy sexual desire alone, but in the marketplace, where tax-gatherers and prostitutes would be likely to keep company.

The Jews of Eretz Israel apparently frequented prostitutes to a certain degree, despite the negative halakhic standing on this. The encounter between sages and prostitutes apparently took place on a sexual level, whether they succumbed to temptation or succeeded in overcoming lust. At times they even wielded a positive influence on the prostitutes, both male and female, enabling them to leave their occupation and in some cases even convert to Judaism.

\section{The Social Aspect}

As incongruous as it may seem today, cult prostitutes belonged to a relatively high social class. Male and female cult prostitutes enjoyed the same social standing. The king's mother herself was the chief votaress of a goddess. After idolatry was suppressed in Jerusalem and all of Eretz Israel, women no longer participated in any form of worship in the temple. Their exclusion from the temple cult reflects the wish expressed by the prophets to protect women's modesty; at the same time, it reflects women's inferior social standing in the cult of Yahweh.

42 See D. Flusser, Yahadut umekorot ha-Nazrut (Sifriyat Poalim, Tel-Aviv, 1979), p. 81 ff. (Hebrew).

43 Compare to the opposition between the hasid and the tax-gatherer in y. Hagigah 2:2, 77d; Midrash Aseret Ha-Dibrot, A. Yellinek, Beit Ha-Midrash, ${ }^{2}$ (Jerusalem, 1938), where the tax-gatherer receives his punishment in the world to come next to Miriam $b$. Eli, who was a prostitute or adulteress. See also b. Shabbat 33b, R. Simeon b. Yohai's opinion of the Romans: "R. Simeon b.Yohai answered and said: "All that they made, they made for themselves; they built marketplaces, to set harlots in them; baths, to rejuvenate themselves; bridges, to levy tolls for them." Here, as in the Christian text, tax-gatherers and prostitutes are mentioned together, this time prejoritively. Cf. Matthew 11:19, where John the Baptist is said to have befriended "tax-gatherers and sinners". 
In contrast to cult prostitutes, ordinary prostitutes in the biblical period and afterwards were on the lowliest social rung. They did not engage in sexual activities for any religious purpose and received no recognition of services rendered to society. Even if society frowned upon their occupation, it was recognized that prostitution would never be wholly abolished. With the exception of priests (Lev. 21:7), anyone was free to marry a prostitute, though objections to this were raised. ${ }^{44}$ The practice of prostitution was legal, and existed from the earliest urban culture in Mesopotamia, throughout the talmudic period and afterwards.

The incidents of contact between sages and prostitutes recounted in talmudic literature derive from Eretz Israel in the second and third centuries C.E.; some of the stories take place outside Israel. The common denominator in all the anecdotes is some degree of contact between sages and prostitutes. The characterization must be noted: never is the prostitute the heroine; she merely provides circumstantial background for the sage. There is no motif in these stories that could be termed "the good-hearted prostitute," which became a familiar motif in later European literature. There is no attempt to condone the behavior of prostitutes. However, compared to the biblical stories, talmudic literature is more tolerant of men who visited prostitutes, and the large number of such stories reflects a degree of familiarity with prostitutes, though not necessarily in the sexual sense.

The stories discussed above show that some sages did visit prostitutes, though such intimate details cannot be confirmed in any degree of exactitude. In one case, a disciple tried to conceal the fact that he consorted with a prostitute, and in another case, such behavior is represented as the turning-point leading to the sage's repentance. Prostitution was abhorrent to the sages, in accordance with the biblical outlook, though they were aware that it addressed a social need.

The national-religious identity of the prostitutes is specified only in some of the stories. We hear of non-Jewish prostitutes in Ashkelon and of one from another land who converted to Judaism. In general, however, there is no certainty as to whether they were Jewish or not. It will be no exaggeration, however, if we conclude that most of the prostitutes

44 It is interesting to see Lev. 21:9 in this context: "When the daughter of a priest defiles herself through harlotry, it is her father whom she defiles; she shall be put to the fire." The legal authority is not denouncing the girl's sin, nor the social consequences, but refers only to the disgrace she brings her father. Compare further to the Mesopotamian prostitute's socio-legal standing: Y. Fleishman, Mehqarim be-Maamado haMishpati shel ha-Yeled ba-Mikra u-va-Mizrah ha-Qadum, Ph.D. dissertation, Bar-Ilan University (Ramat-Gan 1989), p. 359 ff. (Hebrew, unpublished). 
referred to were Jewish. The prostitute who brought the phylacteries to the study-house was surely Jewish, and it makes no difference whether she found the phylacteries by chance or received them as pledge. The fact that sages frequented the same marketplaces as did prostitutes can serve as evidence that they were Jewish prostitutes, though there is no conclusive evidence of this. ${ }^{45}$ The prostitutes belonged to different economic classes; some were "high-class" and were paid large sums of money, while others worked for much less. The wealthy ones owned homes, furniture, gold and silver utensils. The poorer majority were badly off. If one of the customers forgot to pay, or left a pledge and never redeemed it, the prostitute had no choice but to appear in public and demand payment. Payment was also received in goods, such as the kid Judah promised Tamar, as seen from the commentary in Sifre Deut. 23:19, 260 (tr. R. Hammer, New Haven and London, 1986, p. 250) on the verse: "Thou shalt not bring the hire of a harlot" - If one says to a harlot, "Take this lamb for your hire." The prostitute received a kid to eat, a sign of her low social standing and financial straits. ${ }^{46}$

The brothel was situated in the marketplace in the center of town or on a main thoroughfare. There are references to the "prostitutes' marketplace," though this may be literary hyperbole. We learn of prostitutes frequenting the marketplace, and of their activities, from the description of the sages of the sins the Israelites committed with the daughters of Moab (Num. 25). The description seems to reflect a degree of the sages' acquaintance with similar contemporary situations. Sifre Num. 131 recounts:

At that time, the Ammonites and Moabites built enclosures from Beth Hayeshimoth to Mount Hermon. They placed there women selling all sorts of sweetmeats. And the Israelites would come eat and drink. When a man would go out to walk in the marketplace and would seek to take an object from an old women, she would sell it to him at its value, and a young girl would call him from inside: "Take it for less." And he would take it from her on the first day and the second day. On the third day she said to him: "Come inside and choose for yourself, for are you not at home here?" And he went in to her, and she had a pitcher full of wine... And he would drink and the wine burned in him and he said "Obey me," and she took out an impression of Pe"or from under her breast-band, and said to him: "Rabbi, if you want me to obey you, bow down to this..."

45 Cf. b. Mo'ed Katan 16a: "Rabi ruled that disciples be forbidden to sleep in the marketplace," due perhaps to the prostitutes who frequented the marketplace.

46 Cf. m. Temurah 6:2 (tr. Danby, p. 560): "If a man said to his fellow, Here is this lamb for thee so that thee suffer thy bondswoman to lodge with my bondsman." This can perhaps help understand Proverbs 6:2: "The first loaf of bread will go for a harlot," in a different sense from the usual interpretations, according to which a man goes to a prostitute and squanders all his money until he lacks bread to eat. Perhaps the verse means that a man can go to a prostitute for the low price of a loaf of bread. 
The sages were familiar with the practice whereby the brothel owner the madam - would solicit men outside, then young girls would seduce them with the allure of wine and a good price. For the sages, relations with non-Jewish prostitutes were bound up with idolatry. According to the traditions and moral outlook preserved in talmudic material, it seems that the prostitutes in their days had many ways of alluring customers, of which the sages were unaware. ${ }^{47}$

Prostitutes generally were dressed distinctively: When Judah saw Tamar, "he took her for a harlot; for she had covered her face" (Gen. 38:15). This ancient custom changed over the years and the ammoraim were perplexed by the verse: the Eretz Israel sources fail to make clear exactly how the prostitutes were recognizable by their clothing. ${ }^{48}$ By contrast, b. Berakhot 20a has a story of Babylonian origin telling of this matter. R. Ada b. Ahaba saw a heathen woman wearing a red head-dress in the marketplace, and, thinking she was Jewish, tore off her clothes. He then discovered that she was the gentile prostitute Mathon. The story teaches incidentally that in Babylonia, as in Rome, prostitutes would sit in the marketplace clad in red.49

Within the community of prostitutes, relations were often sour. The women would compete for customers, and would occasionally fight

47 An example of a misunderstanding of this sort can be found, in my opinion, in the famous story of the widow of Ephesus, the Hellenistic story alluded to in $b$. Kiddushin $80 \mathrm{~b}$, and quoted there in the Tosafot in the reference beginning: "ki hakhi ma aseh". According to the story, a widow in a cemetery desired a man, and even agreed that he take her husband out of his grave. This story has various parallels. See S. Krauss, "Hagadot Leumioth," HaGoren, 4 (1903), pp. 27-32 (Hebrew). M. ben Gurion, Memekor Yisrael, (Tel Aviv, 1945), V, pp. 84-86 (Hebrew). The story of women's unfaithfulness is told from a man's perspective. It appears that the widow was in fact a prostitute who had come to the cemetery to solicit men (this is clear from Rashi's version of the story in his commentary on b. Abodah Zarah 25b). Luring customers in the cemetery was a known tactic in ancient Naples (and throughout the Hellenistic world), and even in modern Italy. See: D. ben-Amotz, Lizkor velishkoah, Tel-Aviv 1981, p. 24 ff. (Hebrew); A. Scheiber, Essays on Jewish Folklore and Comparative Literature (Akademiai Kiado, Budapest, 1985), pp. 234-235.

48 M. Kelim 24:16 (tr. Danby, p. 640) "There are three kind of head-net: that of a girl, which is susceptible to midras - uncleanness; that of an old woman, which is susceptible to corpse-uncleanness; and that of a harlot, which is not susceptible to any uncleanness." The reference to a harlot is understood by some from the expression 'yotzet la-hutz' here and 'yotzet ha-hutz' in $\mathrm{m}$. Kelim 28:9, from the Aramaic nafkat bara (see, for instance, the Aramaic translations of Gen. 38:15). However, it is unlikely that the sages would discuss the degree of sanctity of the clothing of a prostitute. The phrase seems to refer to clothing worn by women on occasions of leaving the house.

49 The red color of a prostitute's garment might already be mentioned in Jer. 4:30: "What do you accomplish by wearing crimson, by decking yourself in jewels of gold, by enlarging your eyes with kohl?" Perhaps the crimson cord Rahab hung in the window (Josh. 2:21) was also the sign of a brothel. 
with each other, as in the story of the Ashkelon prostitutes. The tannaim were aware of this; $b$. Pesahim 113b reads: "Our Rabbis taught: Three hate one another, viz. dogs, fowls, and Parssee priests, and some say, harlots too."

The sages also knew, however (b. Shabbat 34a), that "[Even] whores paint one another." Perhaps for this reason, the first speaker does not include prostitutes among those who hate each other. At least three historical sources, in addition to the Mishnah, tell of Jewish women taken prisoner by the Romans and forced to engage in prostitution, and this is corroborated by Roman sources. It has already been shown that "The real professional prostitutes on the lists were without exception slaves. The free-living women were generally ex-slaves, freedwomen; at least, they were certainly not Roman by birth." 50 The socio-professional standing of prostitutes in Rome derived from Rome's victory over its enemies, as we learn from some rabbinical sources.

It is not clear what motivated women to engage in prostitution; presumably, a combination of financial need and inability to find any kind of employment were contributing factors. This would be a typical situation for a widow with no husband to provide for her. The professions (trade, clerks) were all masculine. Widows with children to feed were likely candidates for prostitution. In times of war and political instability, there was a concomitant rise in the number of prostitutes, both from choice and enforced captivity. The wealthy prostitutes seemed to be motivated by the lucrative appeal and the ease of the occupation. In this case, greed and luxury won out over any moral scruples.

Three sources speak of male prostitutes. In two cases (which are, perhaps, one and the same), they are motivated by money; in the other the occupation is part of the services demanded in a brothel of a prisoner of war. Neither men nor women lasted long in that occupation. Some preferred death, as in the story of the girls who jumped into the sea. Those who were not capable of committing suicide often died of grief.

Hitherto, literary accounts of individual cases of prostitution have been examined, but actual prostitution in antiquity - and in the modern world as well - must also be addressed. Prostitution is the result of a double moral standard - a man may do what a woman may not. A man is tolerated when he seeks sexual gratification outside the home. Women, however, are forbidden to do so. The ancient ban on a man being alone with a married woman, a religious-social maxim common to many ancient cultures, viewed such intimacy as but a short step from

50 Otto Kiefer, Sexual Life in Ancient Rome (Panther Books, London, 1969), pp. 66-74. 
prostitution. This double standard was expressed in socio-religious values, as well as in practice: men sought sexual gratification with prostitutes, paying with their own money, which their wives could not do. Scholars of the history of sexual mores in Rome claim that prostitution there stemmed from a different reason - the fact that female infants were often put to death. In antiquity it was customary to thin out the population by putting female infants to death or neglecting them. ${ }^{51}$ Based on various studies, scholars reached the conclusion that the proportion between the sexes in Rome was not equal, as might have been expected from a statistical viewpoint. They calculated that there were $17 \%$ fewer women than men. ${ }^{52}$ Adult males were hard put to find a bride, and had to resort to visiting prostitutes, a necessary institution in such a social structure.

This deterministic explanation can only be partly true, since prostitution still flourishes in modern society. Despite age-old religious protestations, prostitution exists among Jews too. Infant girls were never put to death in Jewish societies, as we know from Jewish and other sources. ${ }^{53}$ Prostitution cannot be explained by theoretical hypothesis alone, but we can understand that it is the inevitable result of a masculine society. In a matriarchal society, women would presumably pay men for their services. ${ }^{54}$ History cannot assist in solving this social conundrum, other than by indicating countless precedents for prostitution. ${ }^{55}$ However, a social analysis of the different sources does lead one to believe that prostitution will never be completely abolished.

It is interesting to note that all the literary accounts discussed here preserve a high moral standard, and have no intention of inducing

51 William L. Langer, "Infanticide: A Historical Survey," History of Childhood Quarterly, I, 3 (1974), pp. 353-365; Sarah B. Pomeroy, "Infanticide in Hellenistic Greece", Averil Cameron and Amelie Kuhut (eds.), Images of Women in Antiquity (Croom Helm, London and Canberra, 1983), pp. 207-222; Marvin Kohl (ed.), Infanticide and the Value of Life (Promotheus Books, New York, 1978).

52 The figures are from Kiefer, above, n. 50.

53 See Judges 12:8: "After him, Ibzan of Bethlehem led Israel. He had thirty sons, and he married off thirty daughters outside the clan and brought in thirty girls from outside the clan for his sons"; II Chron. 11:21: "He begot twenty-eight sons and sixty daughters, of King Rehoboam." It should be noted that in the intrigues of the king's court, there was a tendency to kill male infants, not female ones. King Abijah married fourteen wives and begat twenty-two sons and sixteen daughters (II Chron. 13:21; m. Makhshirin 2:7; $\mathrm{t}$. Makhshirin 1:8).

54 Male prostitutes mentioned above were probably homosexuals, as evident in the Sibylline oracles $3,185-6 ; 5,487$.

55 The old saw of prostitution as the oldest profession in the world is not based on Jewish sources. See: Lujo Basserman, The Oldest Profession: A History of Prostitution (Stein and Day, New York, 1968). 
sexual arousal, as erotic literature does. ${ }^{56}$ The purpose of the anecdotes in rabbinical literature about prostitutes in the world of the sages was to raise men's moral standards and keep them from sinning, not to titillate. Repentance is the central motif, not lust.

This moralistic trend grows stronger in the stories of the sages who made an effort to free Jewish women from captivity, i.e., from brothels. The prostitutes enabled the sages to fulfill the commandment of redeeming prisoners. Despite their situation, some of the women in the brothels tried to keep pure, and to uphold their moral and Jewish standards even in the most difficult circumstances.

\section{Conclusion}

Biblical and talmudic sources disclose a surprising degree of familiarity with prostitutes on the part of prophets and sages. Prostitution was not carried out in secrecy; at times it was denounced, at others accepted without reproach, and some prostitutes even converted to Judaism. Some contact between sages and prostitutes was the result of the Roman conquest, other contact resulted from circumstances that threw them together. Infrequently, sages sought out prostitutes of their own accord. However, the stories should not be taken to show that the talmudic sages regularly frequented prostitutes. On the contrary, not only did they categorically denounce prostitution,, 57 they managed to uphold the commandments of sexual restraint and withstand temptation even when they found themselves in close proximity with prostitutes. Moreover, the stories about prostitutes served to teach a religious lesson, and were told openly. Hence, it should not be concluded that the sages did in fact engage in such activities.

56 The most detailed account is in b. Abodah Zarah 65a: "Raba once sent a present to Bar-Sheshak on a heathen feast-day, saying, "I know that he does not worship idols," but on paying him a visit, he found him sitting up to his neck in a bath of rose-water while naked harlots were standing before him. [Bar Sheshak] said to him: "Have you [Israelites] anything like this in the World to Come? He replied, "We have much finer than this." He asked, "Is there anything finer than this?." This vision of heaven predates the Koran. On women as a sexual object in Islam, see: Vern L. Bullough, The Subordinate Sex (Penguin Books, New York-Baltimore, 1974), pp. 134-152.

57 See for instance: $b$. Sotah 4b: "Whoever has intercourse with a harlot will in the end go seeking a loaf of bread"; Lev. Rabbah (tr. J. Israelstam, London, 1939, p. 297): "When Israel were in Egypt the Egyptians practised whoredom, as it says, "Whose flesh is as the flesh of asses" (Ezek. 23:20). When they entered the land of Canaan the Canaanites practised whoredom and witchcraft... the Holy One, blessed be He, said to them: "My children, be careful that you do not act either in accordance with the practice of these or in accordance with the practice of these." See also: A. S. Hirschberg, "Yofya vehityapputa shel ha-isha bizman ha-Talmud", Heatid, 4 (1923) pp. 1-52 (Hebrew). 
There is but meager information as to the social standing of prostitutes. Unlike cult prostitutes, ordinary prostitutes were evidently motivated by a combination of factors: financial considerations, low social circumstances, captivity. However, the institution of prostitution in general can be said to stem from the overall structure of patriarchal society and the double moral standard it postulates. This would support the opinion that prostitution can never be completely eradicated. ${ }^{58}$ It is not the prostitutes who occupy the focus of the rabbinical sources, but the righteous sages who did not sin with prostitutes, and who fulfilled the commandment of redeeming prisoners from captivity. Those sages who did sin with prostitutes ultimately repent. The proximity of the two social circles resulted in temptation that was hard for the sages to resist, though apparently very few of them succumbed.

58 On Jewish prostitutes in the Middle Ages in Italy see S. Simmonson, Toldot hayehudim be-dukasut Mantowa, Tel-Aviv-Jerusalem, 1965, p. 154 ff, 394 ff. (Hebrew). On Jewish prostitutes at the end of the nineteenth century and in the twentieth century, see: Edward J. Bristow, Prostitution and Prejudice, (Schocken Books, New York, 1983). 


\section{Afterword}

This volume was conceived over a decade ago, when I was studying the social history of antiquity. Since then, studies in this field have proliferated, and the women of antiquity have come into their own; hardly a journal appears today that does not contain at least one article about women. The change is marked by new methodology as well as by increased quantity: a comparison of recently published studies of women in the Bible reveals that the underlying methodological approaches result in radically different descriptions of the same character. Such diversity is a boon to scholarship, although I was somewhat apprehensive that by the time my book appeared in print, another scholar would have preceded me. Fortunately the field is vast enough that the great many studies and the occasional overlapping of their subjects yield highly differentiated conclusions. This can be attributed to the variety of methodological approaches of the various studies, an indication that the study of women in antiquity has matured. The current abundance shows no signs of slackening in the near future: the study of women in antiquity may yet disclose new aspects not hitherto discussed, ushering in a new future for students of the past.

The present volume has been concluded, then, but the ongoing study is far from complete; indeed the study of women in antiquity is still in its early stages, and it is still too early to sum it up. Suffice it to say, for now, that each new historical study of women highlights once more the neglect this field has suffered. It is incumbent upon us to put an end to this oversight of such an important part of humankind, quite unjustified scientifically, certainly in the enlightened modern world which acknowledges otherness and minority groups.

We may be permitted, however, the following observation: there is no single formula governing historical inquiry, nor any fixed method that can be applied to non-Jewish archaeological or literary sources to glean from them knowledge of Jewish history. The non-Jewish sources in this book are treated with a gamut of approaches and represent such a wealth of cultures that it becomes apparent that a socio-historical study cannot afford to ignore anything that falls into its scope. Only a thorough investigation will determine if a given text or archaeological find can shed further light on Jewish history or must be relegated to obscurity. I am convinced that modern historiography will soon be 
spurred to devote renewed attention to historical findings: time alone will tell.

The methodology followed in this volume situates it in the stream of modern historiography which evinces an interest in daily life, and addresses questions about antiquity raised by historians and laymen alike, as we approach the third millennium.

I do not aspire to provide any conclusive answers to questions raised a century ago, after the fashion of political historiography, rather, I have responded to observations that might be raised by a modern reader of the Bible, the apocrypha and the talmudic texts. These questions arise in the context of the social and anthropological sciences, and disregard the momentous events and prominent figures of history, preferring to deal with daily life. The study of women is, in fact, merely an excuse to study the so-called trivia that make up quotidian activity, an area treated with contempt, at best, in political historiography. The study of women is, in my opinion, not an eccentric preference, as deemed by certain historians, nor is it feminist in nature, as held by others (women scholars, in the main). The study of women is for me an integral part of our understanding of past societies, and I trust that in the near future my opinion will be shared by everyone.

I employed the term "historical inquiry" above, since I maintain that true scholarship boils down to asking the right question, not necessarily supplying the right answers. I will therefore be content if several colleagues reach different conclusions than my own in the present study; I will be glad, however, to learn that they agree insofar as the book raises the right questions.

I will not be surprised to learn that my book might be considered incomplete, since it analyzes specific characteristics of the figures it discusses, without supplying a comprehensive description of a single biblical figure. Esther, for instance, is mentioned in chapter 1 (should she be considered a heroine?) as well as in chapter 2 (was she literate?) and chapter three (did she pray?). For an extensive profile of women in the biblical and post-biblical period, the reader must seek other studies, and such are too numerous to list. But it is the approach stressing the individual quality, not the biblical character as a whole, which enables one to neutralize the literary topos; rather than discussing a "wellrounded" character, thereby accepting the literary conventions and begging the question whether we are dealing with a literary or historical source, each character becomes a compilation of separate qualities that coalesce like the pieces of a jigsaw puzzle. This approach enables the historian to defuse at least partially the basic shortcoming of the Bible, 
the apocrypha, and to a certain degree the talmudic corpus as well, namely, their status as primarily literary, not historical sources. Having done that, we then proceed to trace a certain quality through the different historical sources.

The claim has been made that times of prosperity render the historian idle, but this book would argue the opposite: it is calm, uneventful daily life, with no war or political event on the horizon, that awards the social historian his or her finest hour. 


\section{Selected Bibliography}

Archer, Leonie J., Her Price is Beyond Rubies - The Jewish Woman in Graco-Roman Palestine, JSOT Press, Sheffield, 1990.

Ashkenazi, S., Ha-Isha be-Aspaklariyyat ha-Yahadut, Yizra'el, Tel-Aviv, 1943-46 (Hebrew).

Baskin, Judith, 'The Separation of Women in Rabbinic Judaism', Yvonne Y. Haddad and Elison B. Findly (eds.), Women, Religion and Social Change, State University of New York, New York, 1985, pp. 3-18.

Biale, Rachel, Women and Jewish Law, Schocken Books, New York, 1984.

Bird, Phyllis, 'Images of Women in the Old Testament', Rosmary Radford Ruether (ed.), Religion and Sexism, Simon and Schuster, New York, 1974, pp. 41-88.

Bird, Phyllis, 'The Place of Women in the Israelite Cultus', Patrick D. Miller (and others, eds.), Ancient Israelite Religion, Essays in Honor of Frank Moore Cross, Fortress, Philadelphia, 1987, pp. 397-419.

Brenner, Athalya, The Israelite Woman, JSOT Press, Sheffield 1985.

Brooke, George J., (ed.), Women in the Biblical Tradition, The Edwin Mellen Press, Lewiston - Qeenston - Lampeter, 1992.

Cameron, Averil, and Amelie Kuhrt (eds.), Images of Women in Antiquity, Croom Helm, London - Canberra, 1983.

Carmichael, Calum M., Women, Law, and the Genesis Traditions, Edinburgh University Press, Edinburgh, 1979.

Charlesworth, James H. (ed.), The Old Testament Pseudepigrapha, Doubleday \& Company, Garden City, 1983-85.

Chase, Debra A., 'Selected Bibliography', Day, Peggy L. (ed.), Gender and Difference in Ancient Israel, Fortress, Minneapolis, 1989.

Darr, Katheryn P., Far More Precious than Jewels, Westminster/John Knox Press, Louisville, Kentucky, 1991.

Day, Peggy L. (ed.), Gender and Difference in Ancient Israel, Fortress Press, Minneapolis, 1989, pp. 58-74.

Daube, David, Civil Disobedience in Antiquity, Edinburgh 1972.

Deen, Edith, All of The Women of The Bible, Harper \& Brothers, New York, 1955.

Diakonof, I. M., 'Women in Old Babylonia not under Patriarchal Authority', Journal of Economic and Social History of the Orient, 29 (1986), pp. 225-238.

Fantham Elaine, Helene Peet Foley (and others, eds.), Women in the Classical World, Oxford University Press, New-York-Oxford, 1994.

Friedman, Th., 'The Shifting Role of Women, From the Bible to Talmud', Judaism, 36 (1986), pp. 479-487.

Greenspan, F. E., 'A Typology of Biblical Women', Judaism, 32 (1983), pp. 43-50.

Gordon, C. H., 'The Status of Women Reflected in the Nuzi Tablets', Zeitschrift fuer Assyriologie und verwandte Gebiete, 43 (1936), pp. 146-169.

Hacket, Jo Ann, 'In the Days of Jael: Reclaiming the History of Women in Ancient Israel', Clarissa W. Atkinson (and others, eds.), Immaculate and Powerful, The Harvard Women's Studies in Religion Series, Beacon Press, Boston, 1987, pp. 15-38.

Hacket, Jo Ann, 'Women's Studies and the Hebrew Bible', Richard E. Friedman and H. G. M. Williamson (eds.), The Future of Biblical Studies, Scholars Press, Atlanta, 1987, pp. 141-164.

Hauptman, Judith, 'Images of Women in the Talmud', Rosmary Radford Ruether (ed.), Religion and Sexism, Simon and Schuster, New York 1974, pp. 184-212.

Horst, Pieter W., van der, 'Images of Women in the Testament of Job', Michael A. Knibb and Pieter W. van der Horst (eds.), Studies on the Testament of Job, Cambridge University Press, Cambridge, 1989, pp. 93-116. 
Ilan, Tal, Jewish Women in Greco-Roamn Palestine, J.C.B. Mohr, Tuebingen, 1995.

Laffey, Alice L., An Introduction to the Old Testament: A Feminist Perspective, Fortress, Philadelphia, 1988.

Levine, Amy-Jill (ed.), "Women Like This": New Perspectives on Jewish Women in the Greco-Roman World, Scholars Press, Atlanta, Georgia, 1991.

Ljung, Inger, Silence or Suppression: Attitudes towards women in the Old Testament, Almqvist \& Wiksell, Stockholm, 1989.

MacDonald, Elizabeth Mary, The Position of Women as reflected in Semitic Codes of Law, University of Toronto, Toronto, 1931.

Mayer, Guenter, Die juedische Frau in der hellenistisch-roemischen Antike, Kohlhammer, Stuttgart - Berlin - Koeln - Mainz, 1987.

Meyers, Carol, Discovering Eve: Ancient Israelite Women in Context, Oxford University Press, New York - Oxford, 1988.

Otwell, John H., And Sarah Laughed: The Status of Women in the Old Testament, Westminster Press, Philadelphia, 1977.

Patai, R., Family, Love and the Bible, MacGibbon \& Kee, London, 1960.

Patai, R., Sex and Family in the Bible and in the Middle East, Garden City, New York, 1959.

Swidler, L., Women in Judaism: The Status of Women in Formative Judaism, Scarecrow Press, Metuchen NJ, 1976.

Trenchard, Warren C., Ben Sira's View of Women: A Literary Analysis, Brown Judaic Studies 38, Scholars, Chico, 1982.

Vos, Clarence J., Women in Old Testament Worship, Amsterdam, n.d. (1968).

Wegner, Judith Romney, Chattel or Person: The Status of Women in the Mishnah, Oxford University Press, New York - Oxford, 1988.

Wenig, Steffen, The Woman in Egyptian Art, McGraw-Hill, NewYork, 1969.

Williams, James G., Women Recounted, The Almond Press, Sheffield, 1982.

Zakovitz, Y., 'Ha-Isha ba-Sipporet ha-Mikra'it - Mitveh', Beit Mikra, 32 (1987), pp. 1432 (Hebrew).

Zmora, Y., Nashim ba-Tanakh, Mahbarot le-Sifrut, Tel-Aviv, 1964 (Hebrew). 


\section{Index of Women in Antiquity}

Abigail wife of Asiyahu - 2,25

'Adata wife of Pashhur - 2,30

Ahat daughter of Nasri - 2,24

Ahatmelech wife of Yesha - 2,27

'Aliya servant of Hannanel - 2,31

'Amadyahu daughter of Shabanyahu 2,30

Amaltheia's Horn, daughter of Job - 3,45; 4,52

Amathlai, the daughter of Karnebo 3,32

Amathlai, the daugther of Orabti - 3,32

Amzarra wife of Rekhael - 3,32

Anamawet servant of Dabalbes - 2,25

Anna, the prophetess - 4,64

Asenath $-4,25$

Athaliah - 1,7;1,8

Avihai daughter of 'Aziya - 2,31

Avihai daughter of Yenahem - 2,31

Azora, daughter of Eve - 3,32

Balti-matim - 2,4

Batasham - 2,25

Batnush daughter of Berakhel - 3,32

Berakha, daughter of Rezuel - 3,32

Beruria - 1,48; 2,58; 6,32

Deborah - 1,$13 ; 2,21 ; 2,23 ; 3,7 ; 3,28 ; 3,29$; 4,4; 4,14; John G. 4,72

Delilah - 3,29

Dina - 1,$52 ; 3,45$

Dina, daughter of Berakhiel - 3,32

Edna, daughter of Daniel - 3,32

Elsegev (daughter of) Elshem'a - 2,31

Esther - 1,15-18; 1,60; 2,16; 4,46

Eve - 1,6; 4,17

Gomer daughter of Diblaim - 6,16

Hagar - 4,61

Hamiohel daughter of Menahem - 2,26

Hannah (on a seal) - 2,32

Hannah - 3,29; 4,11-15; 4,18; 4,20; 4,34-38; 4,$45 ; 4,61$
Hasophereth (she-scribe) - 2,19

Hemera, daughter of Job - 3,45

Herea, Job's daughter $-4,52$

Hulda - 2,21

Jael - 1,$13 ; 1,22 ; 4,4 ; 4,30$

Jehosheba - 1,7

Jezebel - 1,$6 ; 2,13 ; 5,5 ; 5,6$

Jochebed - 1,1

Yohani daughter of Ratibi $-5,31$

Judith - $1,10-18 ; 1,23 ; 1,51 ; 3,17 ; 4,53 ; 4,72$

Kassia, daughter of Job - 3,45

Leah - 4,24

Maacha, mother of King Asa - 6,12

Ma' adana, daughter of the king - 2,33

Mahalalit - 3,32

Mathon - 6,48

Menahemet wife of Gadmelech - 2,28

Meshulemet - 2,29

Michal - 1,3

Milham, daughter of Ruth - 3,29

Miriam - 1,1; 1,12; 2,21; 4,2; 4,10; 4,55; 4,61; 4,72

Miriam daughter of Bilgah - 1,40

Miriam daughter of Eli - 6,43

Miriam, teacher of infants $-2,61$

Na'ama - 3,34; 6,29

Naomi - 3,32; 3,42

Ne'ehevet daughter of Remalyahu - 2,27

Nin-tur, wife of Massanfadda - 2,4

Nizbeth, the daughter of Adael - 3,32

Noadia - 2,21

On, daughter of Eve - 3,32

Peninah - 3,29; 4,11; 4,20

Podokhata the Hittite - 2,4

Puah - 1,1

Pyrrhe, scribe of Rubria Helvia -2,48

Rachel - 1,$5 ; 4,11 ; 4,21 ; 4,24 ; 4,61$ 
Rahab - 1,$2 ; 6,8 ; 6,9 ; 6,21 ; 6,49$

Rebekah - 4,11;4,19;4,20;4,45;4,61

Sadakla daughter of Adod - 3,29

Sara $-1,17 ; 4,11$

Sara, wife of Tobias $-4,56$

Serah $-\mathbf{1 , 7}$

Shaila (Jephthah's daughter) - 3,33

Sheshet the goddess - 2,10

Shimi's wife - 1,6

Shibbatu, wife of Zimri-lim - 2,4

Shiphrah - 1,1

Shelomit maidservant of Elnatan Peha 2,34

Shlurtum, of Uruk - 2,4

Shulgi-Simati, Queen of Ur - 2,4

Sitis, Job's wife - 3,$32 ; 3,41 ; 4,51$

Susanna - $1,25-31 ; 1,60 ; 4,62$

Tamar, daughter of David - 1,19-24; 1,60; 4,$39 ; 4,52$

Tamar, daughter-in-law of Judah - 1,27 $29 ; 3,29 ; 4,25 ; 4,58 ; 6,5 ; 6,24 ; 6,46$

Taonana, wife of Shupiluliuma - 2,4

Trajan's wife - 1,49

Vashti $-6,33$

Yeho'eden daughter of Ariyahu - 2,29

Yehoyishm'a daughter of Shaush-sharusur - 2,31

Yizevel - 2,25

Zaphenat, daughter of Peni'el - 4,64

Zipporah - 1,2; 1,35-37, 1,52

Zofanima, wife of $\mathrm{Nir}-3,32$ the circumcising woman - $1,32-40$

the Woman and her Seven Sons - 1,41-43

a woman from Bahurim - 1,5

a woman of Abel Beth-maacha - 1,14

a woman of Thebez - 1,14

the woman from En-Dor - 5,3

clever woman - 1,$6 ; 3,6$

daughter of the emperor - 5,42

daughter of $R$. Zadok - 2,56

daughter of R. Jose of Yokereth - 4,66

daughters of R. Nahman - 5,30

daughter of Jephthah - 3,29;3,30;3,34; 6,$10 ; 6,11$

daughters of Israel - 5,17

daughters of men - 5,9

daughter of Pharaoh - 1,1; 1,3

daughter of Zadok the priest - 6,36

daughters of Zelophehad - 3,39

maidservant of Rabbi Judah - 4,66

maidservant of the daughter of

Pharaoh's - 1,1

mother of Micah - 3,29

mother of Samson - 3,29; 4,33

mother of Sisera - 3,8; 4,6

the praying maiden $-4,68$

widow $-5,31$

wife of Potiphar - 1,31; 1,52

women of Shoken-Zeb - 3,58

women at Ashkelon - 5,13

wife of Abba Hilkiyah - 4,63; 4,68

wife of Lemech - 3,32

wife of Noah - 3,32

wife of Obadiah - 4,41

wife of On - 4,29

wife of $\operatorname{Re}$ u - 3,29 


\section{Index of Modern Scholars}

Aberbach, M. - 2,56

Abramson, S. - 5,31

Alexiou, Margaret $-3,30$

Alon, G. $-4,21$

Alter, R. - 4,13

Ararat, N. - 1,18

Arbeli, Shoshana - 2,4

Archer, Leonie J. - 2,68; 5,37

Artzi, P. - 5,1

Ashkenazy, S. - 1,60; 2,69; 3,16; 5,39

Assaf, S. - 5,16

Astour, Michael C. $-6,6 ; 6,10$

Avigad, N. - 2,24-35; 3,8

Baer, M. - 6,7; 6,22

Baer, Z. - 6,18

Bacher, B.Z. - 5,21

Baines, J. - 2,9; 2,38

Bar-Ilan, M. - 1,11; 1,17; 1,21; 1,32; 1,35; 1,$62 ; 2,1 ; 2,2 ; 2,57 ; 2,62 ; 3,3 ; 3,26 ; 3,29$; 3,$50 ; 3,60 ; 4,4 ; 4,32 ; 4,40 ; 4,44 ; 4,52 ; 5,7$; 5,$12 ; 5,34 ; 5,42 ; 6,2 ; 6,25$

Baroja, J. C. - 5,15

Bartlett, J. R. - 2,32

Bashan, E. - 2,69; 6,36

Basserman, L. - 6,55

Batto, B. F. - 2,4

Bayer, Batya - 3,50

Beck, A. G. - 2,43

Bellis, Alice, O. - 2,20

Ben Dov, M. - 4,72

Bendann, Effie - 3,60;3,61

Ben-Gurion, A. - 1,$17 ; 1,27 ; 3,30 ; 6,47$

Bickerman, E. - 1,17

Bird, Phyllis - 1,1

Botero, J. - 2,6

Boyarin, D. - 2,51

Brand, Y. $-5,30$

Breasted, J. H. - 2,10

Brenner, Athalya - 1,$1 ; 1,35 ; 2,20 ; 3,4 ; 3,20$; 5,$1 ; 6,1$

Bristow, Edward J. - 6,58

Bronner, Leila Leah - 4,15

Brooke, G. J. - 1,26

Brooten, Bernadette J. - 4,72
Brown, Cheryl Anne - 3,29; 5,5

Bryan, Betsy M. - 2,11

Buechler, A. - 1,55

Bullough, Vern L. - 6,56

Burckhardt, J. - 5,48

Cameron, Averil - 2,68

Camp, Claudia V. - 1,7

Charlesworth, C. - 1,10; 2,17; 3,11; 5,10

Chesnutt, Randall D. - 4,21

Childs, B.S. - 1,35

Cipolla, C. M. - 2,40

Cohen, G. D. - 1,41

Cohen, G. H. - 1,8

Cohen, S.J.D. $-4,72$

Cole, Susan G. - 2,42

Coogan, Michael D. - 3,39

Dan, Y. - 1,46; 4,22

Darr, Katheryn P. - 2,18

D'Avino, M. - 2,47

Dayagi-Mendels, Michal - 2,26; 2,34

Demsky, A. - 2,1; 2,13

Dougherty, R. P. - 2,8

Dronke, Peter - 3,30

Dvir, Y. - 4,7; 6,15

Efron, Y. - 5,15

Elboim, Y. - 1,61

Elbogen, I. - 4,61

Eliade, M. - 5,46

Elizur, Y. - 1,3

Epstein, A. - 1,32

Epstein, Louis M. - 1,23; 3,52; 6,1

Evans-Pritchard, E. E. - 5,41

Eyre, C. J. - 2,9; 2,38

Feldman, E. - 3,56

Fewell, Danna Nolan - 4,5

Fleishman, Y. - 6,44

Flusser, D. - 4,16; 6,42

Fisch, H. - 1,17

Fried, N. - 1,33

Friedman, M. A. - 4,58; 6,6

Friedman, T. - 1,1 
Gafni, Y. - 4,56

Gager, John G. - 5,24

Gaster, M. - 4,59

Ginzberg, L. - 3,$30 ; 4,42 ; 5,4 ; 6,11$

Goitein, S. D. - 1,$53 ; 2,20 ; 3,20 ; 5,1$

Goldfeld, Anne - 4,64

Goldschmidt, D. - 4,61

Goodblatt, D. - 1,48

Goodwater, Leanne - 2,50

Goody, Esther - 5,44

Goshen-Gottstein, A. - 6,19

Graff, H. J. - 2,40

Greenberg, M. - 4,1

Greenfield, J. G. - 5,27

Greenspan, F. E. - 2,12

Grintz, Y. M. - 1,10;1,13; 1,15

Gruber, M. - 6,4

Gunn, David M. - 4,5

Gutman, Y. - 1,41

Habermann, A. M. - 1,10; 2,23; 2,69; 4,59; 6,23

Halevi, E. E. - 3,18; 3,63; 4,68; 5,13; 5,21; 5,38

Harris, Rivkah - 2,7

Harris, W. V. - 2,42

Hartom, A. S. - 2,25

Hasterin, Ruth - 2,26; 2,34

Halpern-Amaru, Betsy - 3,29

Harkavy, A. A. - 3,31

Hasan-Rokem, G. - 1,41

Heinemann, J. - 4,19; 4,34

Heller, H. - 5,3

Heltzer, S. - 2,30

Henshaw, Richard A. - 6,4

Herr, M. D. - 5,12

Hirschberg, A. S. - 6,57

Ilan, Tal - 3,39

Ikada, Y. - 4,5

Jacobson, H. - 4,21

Jakobson, Y. - 4,12; 6,16

Johnson, N. B. - 4,16

Kahana, A. - 1,16; 1,25

Kadari, M. Z. - 1,34

Kappah, Y. - 3,66

Karlin, A. - 4,64

Kasher, A. - 1,34; 5,15

Kaufman, Y. - 5,4

Keefe, Alice A. - 1,23
Kephart, W. M. - 3,60

Kiefer, O. - 6,50; 6,52

Klein, Y. - 3,23

Klaus, N. - 4,14

Kohl, M. - 6,51

Kook, S. H. - 5,29

Krauss, S. - 1,46; 6,47

Kuhrt, Amelie - 2,68

LaCocque, A. - 1,27; 4,54

Langer, William L. - 6,51

Lefkowitz, Mary F. - 2,48

Legasse, S. - 6,38

Lehman, M. R. - 5,27

Leiter, N. N. - 2,64

Lerner, M. B. - 1,10

Lesko, Barbara S. - 2,11

Levi, Y. - 5,12

Levine, B. M. - 3,58; 5,31

Levine, Yael - 1,2; 4,73

Lewonstamm, S., - 6,1

Lieberman, S. - 1,18; 1,36; 1,46; 3,50; 4,67; 5,28

Licht, Y. - 1,15; 3,38; 5,36

Lichtenstein, H. - 6,17

Macfarlane, A. - 5,46

Margalit, A. - 6,13

Margaliyot M. - 2,64; 5,11; 5,18

Marmorstein, A. - 5,18

Meyers, E. M. - 2,35

Milikowsky, C. - 4,45

Moore, C. A. - 1,16

Muffs, J. - 4,72

Murray, Margaret A. - 5,23

Neumann, E. - 1,39

Neusner, J. - 5,24

Novele, S. - 1,51

Ohana, M. - 2,30

O'Keefe, Daniel L. - 5,33

Otwell, John H. - 6,1

Ozick, Cynthia - 4,70

Patai, R. - 2,65; 3,21; 5,14; 5,31; 6,1

Pattison, R. - 2,2

Pinner, H. L. - 2,46

Pomeroy, Sarah B. - 6,20; 6,51

Qimron, E. - 6,41 
Reifenberg, A. - 2,31

Rollin, Sue - 5,1

Rosenthal, A. - 4,22

Rubin, N. - 3,47; 3,51; 3,52; 5,44

Safrai, S. - 3,$47 ; 3,55 ; 4,63 ; 4,72$

Scheiber, A. - 6,47

Segal, M.Z. - 5,27

Sekles, S. - 3,58

Setel, Drora, T. $-6,16$

Shahar, Shulamit - 5,6; 5,45

Shechter, S. Z. - 1,20

Shifra, S. - 2,8

Shinan, A. - 4,26

Simmonson, $S .-6,58$

Spiegel, Y.S. - 1,32

Stahl, A. - 2,2

Steinzalz, A. - 1,$8 ; 4,8$

Stern, M. - 1,44;5,12

Stone, M. E. $-5,9^{\circ}$

Strugnell, J. - 6,41

Summers, M. - 5,4

Swidler, L. - 1,50; 2,51; 5,37

Ta-Shma, I. - 6,18

Tedesche, S. S. - 4,15

Thomas, R. - 5,51

Tigai, Y. H. - 3,1; 3,10; 3,11; 3,18; 3,33

Toaff, A. $-5,52$

Tov, Shulamit - 2,58
Trenchard, W. C. - 1,53; 5,35

Trevor-Roper, H. R. - 5,46; 5,47; 5,50

Trible, Phyllis - 3,12

Tur-Sinai, N.H. - 3,22; 4,45; 4,67

Urbach, E. E. - 6,23

van Dijk-Hemmes - 2,20; 3,20

van der Horst, Pieter W. - 3,35; 3,38

Vos, C. J. - 1,35

Wagner, W. H. - 1,39

Weems, Renita, J. - 6,16

Weiss, R. - 3,8

Weinfeld, M. - 6,12

Wennig, S. - 2,11

Westermarck, E. - 6,4

White, Sidnie Ann - 1,10

Wilson-Katner, Patricia - 2,67

Yeivin, S. - 2,25

Youtie, H. C. - 2,44

Zakovits, Y. - 1,14

Zeidel, M. - 4,14

Zeitlin, S. Z. - 1,16

Zeron, A. - 3,28; 3,30

Zinger, Osnat $-3,24$

Zipor, M. - 6,13 



\section{Brown Judaic Studies}

140001 Approaches to Ancient Judaism I

140002 The Traditions of Eleazar Ben Azariah

140003 Persons and Institutions in Early Rabbinic Judaism

140004. Claude Goldsmid Montefiore on the Ancient Rabbis

140005 The Ecumenical Perspective and the Modernization of Jewish Religion

140006 The Sabbath-Law of Rabbi Meir

140007 Rabbi Tarfon

140008 Rabban Gamaliel II

140009 Approaches to Ancient Judaism II

140010 Method and Meaning in Ancient Judaism I

140011 Approaches to Ancient Judaism III

140012 Turning Point: Zionism and Reform Judaism

140013 Buber on God and the Perfect Man

140014 Scholastic Rabbinism

140015 Method and Meaning in Ancient Judaism II

140016 Method and Meaning in Ancient Judaism III

140017 Post Mishnaic Judaism in Transition

140018 A History of the Mishnaic Law of Agriculture:

Tractate Maaser Sheni

140019 Mishnah's Theology of Tithing

140020 The Priestly Gift in Mishnah: A Study of Tractate Terumot

140021 History of Judaism: The Next Ten Years

140022 Ancient Synagogues

140023 Warrant for Genocide

140024 The Creation of the World According to Gersonides

140025 Two Treatises of Philo of Alexandria: A Commentary on De Gigantibus and Quod Deus Sit Immutabilis

140026 A History of the Mishnaic Law of Agriculture: Kilayim

140027 Approaches to Ancient Judaism IV

140028 Judaism in the American Humanities I

140029 Handbook of Synagogue Architecture

140030 The Book of Mirrors

140031 Ideas in Fiction: The Works of Hayim Hazaz

140032 Approaches to Ancient Judaism V

140033 Sectarian Law in the Dead Sea Scrolls: Courts, Testimony and the Penal Code

140034 A History of the United Jewish Appeal: 1939-1982

140035 . The Academic Study of Judaism

$140036 \quad$ Woman Leaders in the Ancient Synagogue

140037 Formative Judaism I: Religious, Historical, and Literary Studies

140038 Ben Sira's View of Women: A Literary Analysis

140039 Barukh Kurzweil and Modern Hebrew Literature

140040 Israeli Childhood Stories of the Sixties: Yizhar, Aloni, Shahar, Kahana-Carmon

140041 Formative Judaism II: Religious, Historical, and Literary Studies

140042 Judaism in the American Humanities II: Jewish Learning and the New Humanities
William S. Green Tzvee Zahavy

William S. Green Joshua B. Stein

S. Daniel Breslauer Robert Goldenberg Joel Gereboff Shamai Kanter William S. Green Jacob Neusner William S. Green Howard R. Greenstein Pamela Vermes Anthony J. Saldarini Jacob Neusner Jacob Neusner

Baruch M. Bokser

Peter J. Haas Martin S. Jaffee Alan. J. Peck Baruch M. Bokser Joseph Gutmann Norman Cohn Jacob J. Staub

Winston/Dillon Irving Mandelbaum William S. Green Jacob Neusner Marilyn Chiat Daniel C. Matt Warren Bargad William S. Green

Lawrence $H$. Schiffman

Marc L. Raphael Jacob Neusner Bernadette Brooten

Jacob Neusner Warren C. Trenchard James S. Diamond

Gideon Telpaz

Jacob Neusner

Jacob Neusner 
140044 The Sanctity of the Seventh Year: A Study of Mishnah Tractate Shebiit

Roger Brooks

140045 Character and Context: Studies in the Fiction of Abramovitsh, Brenner, and Agnon

140046 Formative Judaism III: Religious, Historical, and Literary Studies

140047 Pharaoh's Counsellors: Job, Jethro, and Balaam in Rabbinic and Patristic Tradition

140048 The Scrolls and Christian Origins: Studies in the Jewish Background of the New Testament

140049 Approaches to Modern Judaism I

$140050 \quad$ Mysterious Encounters at Mamre and Jabbok

140051 The Mishnah Before 70

140052 Sparda by the Bitter Sea: Imperial Interaction in Western Anatolia

140053 Hermann Cohen: The Challenge of a Religion of Reason 140054 Approaches to Judaism in Medieval Times I

140055 In the Margins of the Yerushalmi: Glosses on the English Translation

140056 Approaches to Modern Judaism II

140057 Approaches to Judaism in Medieval Times II

140058 Midrash as Literature: The Primacy of Documentary Discourse

140059 The Commerce of the Sacred: Mediation of the Divine Among Jews in the Graeco-Roman Diaspora

140060 Major Trends in Formative Judaism I: Society and Symbol in Political Crisis

140061 Major Trends in Formative Judaism II: Texts, Contents, and Contexts

140062 A History of the Jews in Babylonia I: The Parthian Period

140063 The Talmud of Babylonia: An American Translation XXXII: Tractate Arakhin

140064 Ancient Judaism: Debates and Disputes

140065 Prayers Alleged to Be Jewish: An Examination

of the Constitutiones Apostolorum

140066 The Legal Methodology of Hai Gaon

140067 From Mishnah to Scripture: The Problem of the Unattributed Saying

140068 Halakhah in a Theological Dimension

140069 From Philo to Origen: Middle Platonism in Transition

140070 In Search of Talmudic Biography: The Problem of the Attributed Saying

140071 The Death of the Old and the Birth of the New: The Framework of the Book of Numbers and the Pentateuch

Louis E. Newman

Jeffrey Fleck

Jacob Neusner

Judith Baskin

Matthew Black Marc Lee Raphael

William T. Miller

Jacob Neusner

Jack Martin Balcer

William Kluback

David R. Blumenthal

Jacob Neusner

Marc Lee Raphael

David R. Blumenthal

Jacob Neusner

Jack N. Lightstone

Jacob Neusner

Jacob Neusner

Jacob Neusner

Jacob Neusner

Jacob Neusner

David Fiensy

Tsvi Groner

Jacob Neusner

David Novak

Robert M. Berchman

Jacob Neusner

Dennis T. Olson

140072 The Talmud of Babylonia: An American Translation XVII: Tractate Sotah

Jacob Neusner

140073 Understanding Seeking Faith: Essays on the Case of Judaism II: Literature, Religion and the Social Study of Judiasm

Jacob Neusner

140074 The Talmud of Babylonia: An American Translation VI: Tractate Sukkah

Jacob Neusner

140075 Fear Not Warrior: A Study of 'al tira' Pericopes in the Hebrew Scriptures

Edgar W. Conrad 
Formative Judaism IV: Religious, Historical, and Literary Studies

140077 Biblical Patterns in Modern Literature

140078 The Talmud of Babylonia: An American Translation

I: Tractate Berakhot

140079 Mishnah's Division of Agriculture: A History and Theology of Seder Zeraim

140080 From Tradition to Imitation: The Plan and Program of Pesiqta Rabbati and Pesiqta deRab Kahana

Jacob Neusner

Hirsch/Aschkenasy

Jacob Neusner

Alan J. Avery-Peck

Jacob Neusner

140081 The Talmud of Babylonia: An American Translation

XXIII.A: Tractate Sanhedrin, Chapters 1-3

140082 Jewish Presence in T. S. Eliot and Franz Kafka

140083 School, Court, Public Administration: Judaism

and its Institutions in Talmudic Babylonia

140084 The Talmud of Babylonia: An American Translation XXIII.B: Tractate Sanhedrin, Chapters 4-8

140085 The Bavli and Its Sources: The Question of Tradition in the Case of Tractate Sukkah

140086 From Description to Conviction: Essays on the History and Theology of Judaism

140087 The Talmud of Babylonia: An American Translation

XXIII.C: Tractate Sanhedrin, Chapters 9-11

140088 Mishnaic Law of Blessings and Prayers: Tractate Berakhot

140089 The Peripatetic Saying: The Problem of the Thrice-Told Tale in Talmudic Literature

140090 The Talmud of Babylonia: An American Translation

XXVI: Tractate Horayot

Jacob Neusner

Melvin Wilk

Jacob Neusner

Jacob Neusner

Jacob Neusner

Jacob Neusner

Jacob Neusner

Tzvee Zahavy

Jacob Neusner

Martin S. Jaffee

140091 Formative Judaism V: Religious, Historical, and Literary Studies

140092 Essays on Biblical Method and Translation

140093 The Integrity of Leviticus Rabbah

140094 Behind the Essenes: History and Ideology of the Dead Sea Scrolls

140095 Approaches to Judaism in Medieval Times III

140096 The Memorized Torah: The Mnemonic System of the Mishnah

140097

Knowledge and Illumination

140098 Sifre to Deuteronomy: An Analytical Translation I:

Pisqaot 1-143. Debarim, Waethanan, Eqeb

140099 Major Trends in Formative Judaism III: The Three Stages

in the Formation of Judaism

Jacob Neusner

Edward Greenstein

Jacob Neusner

Philip R. Davies

David R. Blumenthal

Jacob Neusner

Hossein Ziai

Jacob Neusner

Jacob Neusner

140101 Sifre to Deuteronomy: An Analytical Translation II:

Pisqaot 144-357. Shofetim, Ki Tese, Ki Tabo, Nesabim,

Ha'azinu, Zot Habberakhah

140102 Sifra: The Rabbinic Commentary on Leviticus

140103 The Human Will in Judaism

140104 Genesis Rabbah I: Genesis 1:1 to 8:14

140105 Genesis Rabbah II: Genesis 8:15 to 28:9

140106 Genesis Rabbah III: Genesis 28:10 to 50:26

140107 First Principles of Systemic Analysis

140108 Genesis and Judaism

140109 The Talmud of Babylonia: An American Translation

XXXV: Tractates Meilah and Tamid

140110 Studies in Islamic and Judaic Traditions I

Jacob Neusner

Neusner/Brooks

Howard Eilberg-Schwartz

Jacob Neusner

Jacob Neusner

Jacob Neusner

Jacob Neusner

Jacob Neusner

Peter J. Haas

Brinner/Ricks 
140112 The Tosefta: Its Structure and its Sources

140113 Reading and Believing

140114 The Fathers According to Rabbi Nathan

140115 Etymology in Early Jewish Interpretation: The Hebrew Names in Philo

140116 Understanding Seeking Faith: Essays on the Case of Judaism I:

Debates on Method, Reports of Results

Jacob Neusner Jacob Neusner Jacob Neusner Jacob Neusner

Lester L. Grabbe

140117 The Talmud of Babylonia: An American Translation VII: Tractate Besah

140118 Sifre to Numbers: An American Translation and Explanation I: Sifre to Numbers 1-58

140119 Sifre to Numbers: An American Translation and Explanation II: Sifre to Numbers 59-115

Jacob Neusner

Alan J. Avery-Peck

Jacob Neusner

Jacob Neusner

140120 Cohen and Troeltsch: Ethical Monotheistic Religion and Theory of Culture

140121 Goodenough on the History of Religion and on Judaism

140122 Pesiqta deRab Kahana I: Pisqaot 1-14

140123 Pesiqta deRab Kahana II: Pisqaot 15-28 and Introduction to Pesiqta deRab Kahana

140124 Sifre to Deuteronomy: Introduction

140126 A Conceptual Commentary on Midrash Leviticus Rabbah: Value Concepts in Jewish Thought

140127 The Other Judaisms of Late Antiquity

140128 Josephus as a Historical Source in Patristic Literature through Eusebius

140129 Judaism: The Evidence of the Mishnah

140131 Philo, John and Paul: New Perspectives on Judaism and Early Christianity

140132 Babylonian Witchcraft Literature

140133 The Making of the Mind of Judaism: The Formative Age

140135 Why No Gospels in Talmudic Judaism?

140136 Torah: From Scroll to Symbol Part III: Doctrine

140137 The Systemic Analysis of Judaism

140138 Sifra: An Analytical Translation I

140139 Sifra: An Analytical Translation II

140140 Sifra: An Analytical Translation III

140141 Midrash in Context: Exegesis in Formative Judaism

140142 Sifra: An Analytical Translation IV

140143 Oxen, Women or Citizens? Slaves in the System of Mishnah

140144

140145

The Book of the Pomegranate

140146

Wrong Ways and Right Ways in the Study of Formative Judaism

Sifra in Perspective: The Documentary Comparison of the

Midrashim of Ancient Judaism

$140147 \quad$ Uniting the Dual Torah: Sifra and the Problem of the Mishnah

140148 Mekhilta According to Rabbi Ishmael: An Analytical

Translation I

140149 The Doctrine of the Divine Name: An Introduction to Classical Kabbalistic Theology

$140150 \quad$ Water into Wine and the Beheading of John the Baptist

140151 The Formation of the Jewish Intellect

140152 Mekhilta According to Rabbi Ishmael: An Introduction

to Judaism's First Scriptural Encyclopaedia

Wendell S. Dietrich

Neusner/Frerichs

Jacob Neusner

Jacob Neusner

Jacob Neusner

Max Kadushin

Alan F. Segal

Michael Hardwick

Jacob Neusner

Peder Borgen

Tzvi Abusch

Jacob Neusner

Jacob Neusner

Jacob Neusner

Jacob Neusner

Jacob Neusner

Jacob Neusner

Jacob Neusner

Jacob Neusner

Jacob Neusner

Paul V. Flesher

Elliot R. Wolfson

Jacob Neusner

Jacob Neusner

Jacob Neusner

Jacob Neusner

Stephen G. Wald

Roger Aus

Jacob Neusner

Jacob Neusner 
140153 Understanding Seeking Faith: Essays on the Case of Judaism III:

Society, History, and Political and Philosophical Uses of Judaism

140154 Mekhilta According to Rabbi Ishmael: An Analytical

Translation II

140155 Goyim: Gentiles and Israelites in Mishnah-Tosefta

140156 A Religion of Pots and Pans?

140157 Claude Montefiore and Christianity

140158 The Philosophical Mishnah III: The Tractates' Agenda:

From Nazir to Zebahim

Jacob Neusner

Jacob Neusner

Gary P. Porton

Jacob Neusner

Maurice Gerald Bowler

Jacob Neusner

140159 From Ancient Israel to Modern Judaism I: Intellect

in Quest of Understanding

140160 The Social Study of Judaism I

140161 Philo's Jewish Identity

140162 The Social Study of Judaism II

140163 The Philosophical Mishnah I: The Initial Probe

140164 The Philosophical Mishnah II: The Tractates' Agenda:

From Abodah Zarah Through Moed Qatan

$140166 \quad$ Women's Earliest Records

140167 The Legacy of Hermann Cohen

140168 Method and Meaning in Ancient Judaism

140169 The Role of the Messenger and Message in the Ancient Near East

140171 Abraham Heschel's Idea of Revelation

140172 The Philosophical Mishnah IV: The Repertoire

140173 From Ancient Israel to Modern Judaism II: Intellect

in Quest of Understanding

140174 From Ancient Israel to Modern Judaism III: Intellect

in Quest of Understanding

140175 From Ancient Israel to Modern Judaism IV: Intellect in Quest of Understanding

Neusner/Frerichs/Sarna Jacob Neusner

Alan Mendelson Jacob Neusner Jacob Neusner

Jacob Neusner Barbara S. Lesko William Kluback Jacob Neusner

John T. Greene Lawerence Perlman Jacob Neusner

Neusner/Frerichs/Sarna

Neusner/Frerichs/Sarna

Neusner/Frerichs/Sarna

140176 Translating the Classics of Judaism: In Theory and In Practice

Jacob Neusner

140177

Profiles of a Rabbi: Synoptic Opportunities

in Reading About Jesus

140178 Studies in Islamic and Judaic Traditions II

140179 Medium and Message in Judaism: First Series

140180 Making the Classics of Judaism: The Three Stages

of Literary Formation

140181 The Law of Jealousy: Anthropology of Sotah

140182 Esther Rabbah I: An Analytical Translation

140183 Ruth Rabbah: An Analytical Translation

140184 Formative Judaism: Religious, Historical and Literary Studies

140185 The Studia Philonica Annual 1989

140186 The Setting of the Sermon on the Mount

140187 The Midrash Compilations of the Sixth and Seventh Centuries I

140188 The Midrash Compilations of the Sixth and Seventh Centuries II

140189 The Midrash Compilations of the Sixth and Seventh Centuries III

140190 The Midrash Compilations of the Sixth and Seventh Centuries IV

140191 The Religious World of Contemporary Judaism: Observations and Convictions

140192 Approaches to Ancient Judaism VI

140193 Lamentations Rabbah: An Analytical Translation

140194 Early Christian Texts on Jews and Judaism

140196 Torah and the Chronicler's History Work

Bruce Chilton

Brinner/Ricks

Jacob Neusner

Jacob Neusner

Adriana Destro

Jacob Neusner

Jacob Neusner

Jacob Neusner

David T. Runia

W.D. Davies

Jacob Neusner

Jacob Neusner

Jacob Neusner

Jacob Neusner

Jacob Neusner

Neusner/Frerichs

Jacob Neusner

Robert S. MacLennan

Judson R. Shaver 
140197

140198

140199

140202

140203

140204

140205

140206

140207

140208

140209

140210

140211

140212

140213

140214

140215

140216

140217

140218

140219

140220

140221

140222

140223

140224

140225

140226

140227

140228

140230

140231

140232

140233
Song of Songs Rabbah: An Analytical Translation I

Song of Songs Rabbah: An Analytical Translation II

From Literature to Theology in Formative Judaism

Maimonides on Perfection

The Martyr's Conviction

Judaism, Christianity, and Zoroastrianism

in Talmudic Babylonia

Tzedakah: Can Jewish Philanthropy Buy Jewish Survival?

Neusner/Borgen/Frerichs/Horsley

New Perspectives on Ancient Judaism I

Scriptures of the Oral Torah

Christian Faith and the Bible of Judaism

Philo's Perception of Women

Case Citation in the Babylonian Talmud: The Evidence

Tractate Neziqin

The Biblical Herem: A Window on Israel's Religious Experience

Goodenough on the Beginnings of Christianity

Eugene Weiner/Anita Weiner

Jacob Neusner

Jacob Neusner

Jacob Neusner

Menachem Kellner

The Talmud of Babylonia: An American Translation

XXI.A: Tractate Bava Mesia Chapters 1-2

Jacob Neusner

Jacob Neusner

Dorothy Sly

Eliezer Segal

Philip D. Stern

A.T. Kraabel

Jacob Neusner

The Talmud of Babylonia: An American Translation

XXI.B: Tractate Bava Mesia Chapters 3-4

Jacob Neusner

The Talmud of Babylonia: An American Translation

XXI.C: Tractate Bava Mesia Chapters 5-6

Jacob Neusner

The Talmud of Babylonia: An American Translation

XXI.D: Tractate Bava Mesia Chapters 7-10

Jacob Neusner

Semites, Iranians, Greeks and Romans: Studies

in their Interactions

The Talmud of Babylonia: An American Translation

XXXIII: Temurah

Jonathan A. Goldstein

The Talmud of Babylonia: An American Translation

XXXI.A: Tractate Bekhorot Chapters 1-4

The Talmud of Babylonia: An American Translation

XXXI.B: Tractate Bekhorot Chapters 5-9

Jacob Neusner

Jacob Neusner

Jacob Neusner

The Talmud of Babylonia. An American Translation

XXXVI.A: Tractate Niddah Chapters 1-3

Jacob Neusner

The Talmud of Babylonia: An American Translation

XXXVI.B: Tractate Niddah Chapters 4-10

Jacob Neusner

The Talmud of Babylonia: An American Translation

XXXIV: Tractate Keritot

Paul, the Temple, and the Presence of God

The Book of the People

The Studia Philonica Annual 1990

The Talmud of Babylonia: An American Translation

XXV.A: Tractate Abodah Zarah Chapters 1-2

Jacob Neusner

David A. Renwick

William W. Hallo

David Runia

Jacob Neusner

The Talmud of Babylonia: An American Translation

XXV.B: Tractate Abodah Zarah Chapters 3-5

The Studia Philonica Annual 1991

Jacob Neusner

David Runia

Jacob Neusner

XXVIII.A: Tractate Zebahim Chapters 1-3

David M. Hay

Questions and Answers on Genesis and Exodus

The Talmud of Babylonia: An American Translation

XXVIII.B: Tractate Zebahim Chapters 4-8

Jacob Neusner 
140235 The Talmud of Babylonia: An American Translation XXIX.A: Tractate Menahot Chapters 1-3

Jacob Neusner

140236 The Talmud of Babylonia: An American Translation XXIX.B: Tractate Menahot Chapters 4-7

140237 The Talmud of Babylonia: An American Translation XXIX.C: Tractate Menahot Chapters 8-13

140238 The Talmud of Babylonia: An American Translation XXIX: Tractate Makkot

140239 The Talmud of Babylonia: An American Translation XXII.A: Tractate Baba Batra Chapters 1 and 2

140240 The Talmud of Babylonia: An American Translation XXII.B: Tractate Baba Batra Chapter 3

140241 The Talmud of Babylonia: An American Translation XXII.C: Tractate Baba Batra Chapters 4-6

140242 The Talmud of Babylonia: An American Translation XXVII.A: Tractate Shebuot Chapters 1-3

Jacob Neusner

Jacob Neusner

Jacob Neusner

Jacob Neusner

Jacob Neusner

Jacob Neusner

Jacob Neusner

140243 The Talmud of Babylonia: An American Translation XXVII.B: Tractate Shebuot Chapters 4-8

Jacob Neusner

140244 Balaam and His Interpreters: A Hermeneutical History of the Balaam Traditions

John T. Greene

140245 Courageous Universality: The Work of Schmuel Hugo Bergman

140246 The Mechanics of Change: Essays in the Social History of German Jewry

William Kluback

140247 The Talmud of Babylonia: An American Translation XX.A: Tractate Baba Qamma Chapters 1-3

Steven M. Lowenstein

Jacob Neusner

140248 The Talmud of Babylonia: An American Translation XX.B: Tractate Baba Qamma Chapters 4-7

Jacob Neusner

140249 The Talmud of Babylonia: An American Translation XX.C: Tractate Baba Qamma Chapters 8-10

Jacob Neusner

140250 The Talmud of Babylonia: An American Translation XIII.A: Tractate Yebamot Chapters 1-3

Jacob Neusner

140251 The Talmud of Babylonia: An American Translation XIII.B: Tractate Yebamot Chapters 4-6

Jacob Neusner

140252 The Talmud of Babylonia: An American Translation XI: Tractate Moed Qatan

140253 The Talmud of Babylonia: An American Translation XXX.A: Tractate Hullin Chapters 1 and 2

140254 The Talmud of Babylonia: An American Translation XXX.B: Tractate Hullin Chapters 3-6

140255 The Talmud of Babylonia: An American Translation XXX.C: Tractate Hullin Chapters 7-12

Jacob Neusner

Tzvee Zahavy

Tzvee Zahavy

Tzvee Zahavy

140256 The Talmud of Babylonia: An American Translation XIII.C: Tractate Yebamot Chapters 7-9

Jacob Neusner

140257 The Talmud of Babylonia: An American Translation XIV.A: Tractate Ketubot Chapters 1-3

Jacob Neusner

140258 The Talmud of Babylonia: An American Translation XIV.B: Tractate Ketubot Chapters 4-7

140259 Jewish Thought Adrift: Max Wiener (1882-1950)

140260 The Talmud of Babylonia: An American Translation XIV.C: Tractate Ketubot Chapters 8-13

Jacob Neusner Robert S. Schine

Jacob Neusner 
140261 The Talmud of Babylonia: An American Translation XIII.D: Tractate Yebamot Chapters 10-16

Jacob Neusner

140262 The Talmud of Babylonia: An American Translation XV. A: Tractate Nedarim Chapters 1-4

140263 The Talmud of Babylonia: An American Translation XV.B: Tractate Nedarim Chapters 5-11

140264 Studia Philonica Annual 1992

140265 The Talmud of Babylonia: An American Translation XVIII.A: Tractate Gittin Chapters 1-3

Jacob Neusner

Jacob Neusner

David T. Runia

Jacob Neusner

140266 The Talmud of Babylonia: An American Translation XVIII.B: Tractate Gittin Chapters 4 and 5

Jacob Neusner

140267 The Talmud of Babylonia: An American Translation XIX.A: Tractate Qiddushin Chapter 1

140268 The Talmud of Babylonia: An American Translation XIX.B: Tractate Qiddushin Chapters 2-4

140269 The Talmud of Babylonia: An American Translation XVIII.C: Tractate Gittin Chapters 6-9

140270 The Talmud of Babylonia: An American Translation II. A: Tractate Shabbat Chapters 1 and 2

140271 The Theology of Nahmanides Systematically Presented

140272 The Talmud of Babylonia: An American Translation II.B: Tractate Shabbat Chapters 3-6

140273 The Talmud of Babylonia: An American Translation II.C: Tractate Shabbat Chapters 7-10

140274 The Talmud of Babylonia: An American Translation II.D: Tractate Shabbat Chapters 11-17

Jacob Neusner

Jacob Neusner

Jacob Neusner

Jacob Neusner

David Novak

Jacob Neusner

Jacob Neusner

Jacob Neusner

140275 The Talmud of Babylonia: An American Translation

II.E: Tractate Shabbat Chapters 18-24

Jacob Neusner

140276 The Talmud of Babylonia: An American Translation III.A: Tractate Erubin Chapters 1 and 2

140277 The Talmud of Babylonia: An American Translation III.B: Tractate Erubin Chapters 3 and 4

140278 The Talmud of Babylonia: An American Translation III.C: Tractate Erubin Chapters 5 and 6

Jacob Neusner

Jacob Neusner

Jacob Neusner

140279 The Talmud of Babylonia: An American Translation

III.D: Tractate Erubin Chapters 7-10

Jacob Neusner

140280 The Talmud of Babylonia: An American Translation XII: Tractate Hagigah

140281 The Talmud of Babylonia: An American Translation IV.A: Tractate Pesahim Chapter I

Jacob Neusner

Jacob Neusner

140282 The Talmud of Babylonia: An American Translation IV.B: Tractate Pesahim Chapters 2 and 3

Jacob Neusner

140283 The Talmud of Babylonia: An American Translation IV.C: Tractate Pesahim Chapters 4-6

Jacob Neusner

140284 The Talmud of Babylonia: An American Translation IV.D: Tractate Pesahim Chapters 7 and 8

140285 The Talmud of Babylonia: An American Translation IV.E: Tractate Pesahim Chapters 9 and 10

140286 From Christianity to Gnosis and From Gnosis to Christianity

140287 Studia Philonica Annual 1993

140288 Diasporas in Antiquity

140289 The Jewish Family in Antiquity

140290 The Place of Judaism in Philo's Thought

acob Neusner Jean Magne David T. Runia Shaye J. D. Cohen, Ernest S. Frerichs Shaye J. D. Cohen Ellen Birnbaum 
140294 The Talmud of Babylonia: An American Translation

$$
\text { V. A: Tractate Yoma Chapters } 1 \text { and } 2
$$

Jacob Neusner

140295 The Talmud of Babylonia: An American Translation

V. B: Tractate Yoma Chapters 3-5

Jacob Neusner

140296 The Talmud of Babylonia: An American Translation V. C: Tractate Yoma Chapters 6-8

Jacob Neusner

140297 The Talmud of Babylonia: An American Translation XXII.D: Tractate Baba Batra Chapters Seven and Eight Jacob Neusner

140298 The Talmud of Babylonia: An American Translation XXII.E: Tractate Baba Batra Chapters Nine and Ten

140299 The Studia Philonica Annual, 1994

140300 Sages, Stories, Authors, and Editors in Rabbinic Judaism

140301 From Balaam to Jonah: Anti-prophetic Satire in the Hebrew Bible

140302 The History of Sukkot in the Second Temple and Rabbinic Periods

140303 Tasting the Dish: Rabbinic Rhetorics of Sexuality

140304 The School of Moses: Studies in Philo and Hellenistic Religion

140305 The Studia Philonica Annual, 1995

140306 The Talmud of Babylonia, An American Translation IX, Tractate Rosh Hashanah

140307 Early Rabbinic Civil Law and the Social History of Roman Galilee: Hayim Lapin A Study of Mishnah Tractate Baba Mesia

140308 The Libes Briv of Isaac Wetzlar

140309 The Studia Philonica Annual, 1996

140310 Rashbam's Commentary on Exodus: An Annotated Translation

140311 The Elijah Legends and Jehu's Coup

140312 The Studia Philonica Annual, 1997; Wisdom and Logos:

Studies in Jewish Thought in Honor of David Winston

Jeffrey L. Rubenstein

Michael L. Satlow John Peter Kenney

David T. Runia

Alan J. Avery-Peck

Jacob Neusner

David T. Runia

Richard Kalmin

David Marcus

140313 The Echoes of Many Texts: Reflections on Jewish and Christian

Traditions, Essays in Honor of Lou H. Silberman

Morris M. Faierstein David T. Runia

Martin I. Lockshin Marsha C. White

David T. Runia and Gregory E. Sterling

William G. Dever and J. Edward Wright

$140315 \quad K o l$ Nidre: Studies in the Development of Rabbinic Votive Institutions

140316 Ben Sira's Teaching on Friendship

140317 Some Jewish Women in Antiquity

Moshe Benovitz Jeremy Corley Meir Bar-Ilan

\section{Brown Studies on Jews and Their Societies}

145001

145002

145003

145004
American Jewish Fertility

The Impact of Religious Schooling: The Effects of Jewish

Education Upon Religious Involvement

The American Jewish Community

The Naturalized Jews of the Grand Duchy of Posen

in 1834 and 1835
Calvin Goldscheider

Harold S. Himmelfarb

Calvin Goldscheider

Edward David Luft 
145005 Suburban Communities: The Jewishness of American Reform Jews 145007 Ethnic Survival in America

Gerald L. Showstack

David Schoem

145008 American Jews in the 21st Century: A Leadership Challenge

Earl Raab

\section{Brown Studies in Religion}

147001 Religious Writings and Religious Systems I

147002 Religious Writings and Religious Systems II

147003 Religion and the Social Sciences

Jacob Neusner, et al

Jacob Neusner, et al

Robert Segal 